\title{
Locus of control : de beheersingsorientatie in relatie tot ziekte- en gezondheidsgedrag
}

Citation for published version (APA):

Halfens, R. J. G. (1985). Locus of control : de beheersingsorientatie in relatie tot ziekte- en gezondheidsgedrag. [Doctoral Thesis, Maastricht University]. Rijksuniversiteit Limburg. https://doi.org/10.26481/dis.19851213rh

Document status and date:

Published: 01/01/1985

DOI:

10.26481/dis.19851213rh

Document Version:

Publisher's PDF, also known as Version of record

\section{Please check the document version of this publication:}

- A submitted manuscript is the version of the article upon submission and before peer-review. There can be important differences between the submitted version and the official published version of record.

People interested in the research are advised to contact the author for the final version of the publication, or visit the DOI to the publisher's website.

- The final author version and the galley proof are versions of the publication after peer review.

- The final published version features the final layout of the paper including the volume, issue and page numbers.

Link to publication

\footnotetext{
General rights rights.

- You may freely distribute the URL identifying the publication in the public portal. please follow below link for the End User Agreement:

www.umlib.nl/taverne-license

Take down policy

If you believe that this document breaches copyright please contact us at:

repository@maastrichtuniversity.nl

providing details and we will investigate your claim.
}

Copyright and moral rights for the publications made accessible in the public portal are retained by the authors and/or other copyright owners and it is a condition of accessing publications that users recognise and abide by the legal requirements associated with these

- Users may download and print one copy of any publication from the public portal for the purpose of private study or research.

- You may not further distribute the material or use it for any profit-making activity or commercial gain

If the publication is distributed under the terms of Article $25 \mathrm{fa}$ of the Dutch Copyright Act, indicated by the "Taverne" license above, 
LOCUS OF CONTROL

De beheersingsorlentatie in relatie tot ziekte- en gezondheidagedrag

PROEFSCHRIFT

ter verkrijging van de gread van doctor in de Sociale Hetenscheppen aan de Rijksuniversiteit Limburg te Masatricht, op gezag van de Rector Magnificus, Prof. Dr. F.I.M. Bonke, volgens het besluit van het College van Dekanen, in thet openbaar te verdedigen op vrijogg 13 december 1985 des namiddags an vier uur

door

Rudolph Jozef Gerardus Halfens

geboren te Tegelen in $\mathbf{1 9 5 2}$ 
Promotores: Prof. Dr. A.P.W.M. Appels

Prof. Dr. H. Philipsen

Referenten: Prof. Dr. G.J. Kok

Dr. A.Ph. Visser 
Het onderzoek, warop dit proefschrift berust, werd in belangrijke mate mogelijk gemaakt door de Stichting Nederland oké. 
Tekstverwerking: Mw. J.R.M. Prick

Mw. J.E.L. Rosier-Wolfs

Omslag: Mw. M.J. van Gilla

Druk: $\mathrm{Hr}$. B. Meerstad 
1 INLEIDING

1.1 Verentwoording van de studie

pagina

1.2 Probleemstelling en opzet van anderzoek 2

1.3 Indeling versilag

2 HET CONCEPT BEHEERSINGSORIENTATIE

2.1 De sociale leertheorie 5

2.2 De beheersingsorientatie 7

2.2.1 De beheersingsorientatie binnen de sociale leertheorie 8

2.2.2 De beheersingsorientatie en aanverwante concepten

2.3 De dimensionaliteit van de beheersingsorientatie

2.3.1 Inleiding 14

2.3.2 Beheersende instantie 15

2.3.3 Bekrachtigingagebieden 16

2.3.4 Aard van de bekrachtiging 18

2.3.5 object van de beheersende instantie 18

2.4 Het belang van de beheersingsorientatie 20

2.5 Samenvatting en concluale 20

3 METING VAN DE BEHEERSINGSORIENTATIE 22

3.1 Keuzemomenten in de meting van de beheersingaorientatie

3.1.1 Beheergende instantie 22

3.1.2 Bekrachtigingegebieden 23

3.1.3 Aard van de bekrachtiging 24

3.1 .4 object van de beheergende inatantile 24

3.1 .5 Samenvatting 25

3.2 vier engelstalige meetinatrumenten van de beheeraingeorientatile 25

3.2.1 Algemene beheersingsorientatie-vragenlijgten 26

3.2.1.1 Rotter's locus of control scale 26 3.2 .1 .2 Levenson's MLOC 28 
3.2.2 Gezondheidsspecifieke beheersingsorilen tatie-schalen

3.2.2.1 De health locus of control scale 29

3.2.2.2 De mult1-dimensional health

locus of control sicale

3.2.3 Samenvatting engelstalige beheersingsorientatie vragenlijaten

3.3 Nederlandstalige beheersingsorientatie vragen11 jaten

4 DE BEHEERSINGSORIENTATIE EN GEZONDHEIDS- EN ZIEKTECEDRAG: een literatuuroverzicht

4.1 Demografiache variabelen en gezondheidstoestand

4.1.l Demografische variabelen 36

4.1.2 Gezondheidstoestand 37

4.2 Gezondheids- en ziektegedrag 38

4.2.1. Inleiding 38

4.2.2 Roken 39

4.2.3 Alcoholconsumptie 40

4.2.4 Lichaamsbeweging 41

4.2.5 Gewichtsafname $\quad 42$

4.2.6 Informatie inwinnen 43

4.2.7 Compliance-gedrag 45

4.2.8 Preventieve activiteiten 45

$\begin{array}{ll}4.2 .9 \text { Zlektegedrag } & 47\end{array}$

4.3 Samenvatting en conclusie $\quad 47$

5 VRAAGSTELLINGEN 49

5.1 Onderscheid in intentie tot en feitelijk gedrag

5.2 Het model van Rotter 51

5.2 .1 Zlektegedrag 51

5.2 .2 Gezondheidagedrag $\quad 52$

5.3 Het model van Fiahbein en Ajzen 54

$\begin{array}{ll}5.4 \text { Vraagstellingen } & 56\end{array}$

6 HET ONDERZOEK $\quad 58$

6.1 De opzet $\quad 58$

6.1.1 Het panelonderzoek 58

6.2 De respondenten 61

6.2.1 Representativiteit van het panel 61

6.2.2 Afbakening van het aantal respondenten 67 
6.3 De wariabelen $\quad 68$

6.3.1 Demografigche kennerken 69

6.3.2 Subjectieve gezondheidstoestand $\quad 70$

6.3 .3 Opvattingen 70

6.3.3.1 De algemene beheersingsorientatie 70

6.3.3.2 Gezondheidsopvattingen 71

6.3 .4 Ziektegedrag 74

6.3.4.1 Intentie tot ziektegedrag 74

6.3.4.2 Gerapporteerd ziektegedrag 75

6.3 .5 Gezondheidsgedrag 76

6.3 .5 .1 Algenene leefwijze 76

6.3.5.2 Rookgewoonten $\quad 77$

6.3 .5 .3 Alcoholconsumptie 78

6.3.5.4 Lichnamsbeweging 79

6.3.6 De attitude, subjectieve norm en intentie

ten aanzien van roken en alcoholgebruik 80

6.4 Samenvatting

85

7 BESCHRIJVING VAN DE BEHEERSINGSORIENTATIE

7.1. Het meetingtrument $\quad 86$

7.2 5oortgenoot validiteit 90

7.2.1 De algemene beheergingsorientatie 90

7.2.2 Gezondheidg- en ziekte-opvattingen 91

7.3 Demografische kenmerken en subjectieve

gezondheidstoestand 93

7.3.1 Denografiache kenmerken 93

7.3.2 De subjectieve gezondheidstoestand 93

7.4 Samenvatting 96

8 DE BEHEERSINGSORIENTATIE BINNEN HET MDDEL VAN ROTIER 97

8.1 De analyse-methode 98

8.2 Ziektegedrag 99

8.2.1 Intentie tot ziektegedrag 99

8.2.2 Gerapporteerd ziektegedrag 104

8.2.3 Overeensteming tussen de intentie en het gerapporteerde ziektegedrag 108

8.2.4 Samenvatting 110

8.3 Gezondheidsgedrag 111

8.3.1 Algemene leefwijze 111

8.3.2 Rookgewoontes 113

8.3.3 Alcoholgebruik 115

6.3.4 Lichaamsbeweging 119

8.4 Samenvatting en conclusie 121 
9 DE BEHEERSINGSORIENTATIE BINNEN HET MODEL

VAN FISHBEIN EN AJZEN 123

9.1 Rookgedrag 123

9.1.1 Het model 123

9.1.2 De beheersingsorientatie binnen het model 124

9.2 Alcoholgebrulk $\quad 127$

9.2.1 Het model 127

9.2.2 De beheersingsorientatie binnen het model 128

9.3 Samenvatting en conclusie $\quad 132$

10 DISCUSSIE $\quad 134$

10.1 Semenvating van de resultaten 134

10.2 Methodologische opmerkingen 137

10.3 Theoretiache opmerkingen 138

10.3.1 Het model van Rotter 138

10.3.2 De beheersingsorientatie $\quad 140$

10.3.3 Het model van Fishbein en Ajzen 142

10.4 Practische consequenties 143

10.5 Verder onderzoek 143

$\begin{array}{ll}\text { SAMENVATTING } & 145\end{array}$

$\begin{array}{lr}\text { SUMMARY } & 149\end{array}$

$\begin{array}{ll}\text { LITERATULRL IJST } & 153\end{array}$

$\begin{array}{ll}\text { BI JLAGEN } & 166\end{array}$

$\begin{array}{ll}\text { DANKWOORD } & 181\end{array}$

$\begin{array}{ll}\text { CURR ICULLM VITAE } & 182\end{array}$ 


HOOFDSTUK 1 INLEIDING

\subsection{VERANTWOORDING VAN DE STUDIE}

In 1962 werd door Rotter, Seeman en Liverant het concept locus of control geintroduceerd. Dit concept, dat door Andriessen (1972) vertasld is als beheersingsorientatie, werd onschreven als de mate warin een persoon de op zijn gedrag volgende gebeurtenissen ziet als lets dat hij of zij zelf beheerst of als lets dat door externe factoren, zoals toeval, noodlot of anderen wordt beheerst. Op basis van dit concept zijn twee ideaaltypen te omschrijven, namelijk intern-georienteerden, die van mening $z 1 j n$ det ze zelf veel gebeurtenissen in de hand hebben en extern-georienteerden, die van mening zijn dat ze zelf geen invloed hebben op gebeurtenisaen, ondat deze veroorzaakt worden door factoren buiten henzelf, zoals kans of geluk.

Sinds de introductie van dit concept is er veel onderzoek naar verricht. Sinds enkele jaren wordt het ook gebruikt in onderzoek naar gezondheidsgedrag en wordt het genoend als een mogelijk relevant persoonlijkheldokenmerk voor Gezondheldsvoorlichting en -Opvoeding (GVD); (Reellak, 1982; De Haes, 1985, D1 Matteo, 1982). Deze interesse vanuit GV lo niet vreemd. Gvo onderzoekt hoe bepealde gedragingen tot stand komen en veranderd kunnen worden. Hierbij $j$ beperkt men zich tot gedragingen warvan aangenomen wordt dat deze de gezondheid belnvloeden. Met andere woorden, gedragingen die gezondheid of ziekte als gevolg kunnen hebben. Bij GVo wordt in voorlichtingsboodschappen ook altijd gewezen op deze relatie. De beheersingsorientatie zegt in algemene zin fets over een bepadd aspect van de relatie gedrag-gevolg, namelijk in welke mate een persoon de gevolgen van zilfn gedrag beheerabaar of beinvloedbaar acht.

Een relevante vraag in dit kader is, of degenen die van mening $z \mathbb{H} j n$ dat zij de gevolgen van gedrag, waronder dus gezondheid en ziekte, zelf kunnen beheersen (intern-georienteerden) zich vervolgens ook gezonder gedragen. Met andere woorden of er een directe, positieve platie ls tuBsen een interne beheersingsorientatie en de mate warin men zich gezond gedraagt.

Het is de vraag of de relatie tussen de beheeraingarientatie en het gezondheidg- en ziektegedrag to eenvoudig is. Zo kunnen intern-georlenteerden van mening zijn dat ze zelf de gezondheld kunnen beliviloeden door bijvoorbeeld niet te roken en iets an lichaamsbeweging te doen, maar ex toch de voorkeur aen geven on te roken en niets aan lichaamabeweglng te doen. Zif hechten meer belang aan andere gevolgen van deze gedragingen, bijvoorbeeld dat roken hen ontspant, of dat ze door niets aan lichaamabeweging te doen meer tijd hebben voor hun hobby's. Bij intern-georienteer- 
den $11 j k$ de opvatting of attitude die men over het betreffende gedrag heeft, van belang te zijn. Bij extern-georienteerden dearentegen, lijkt Lets anders van belang te zijn voor het uiteindelijke gedrag. Extern-georienteerden leggen de beheersing wan gebeurtenisaen bij externe factoren, bijwoorbeeld kans of geluk, maer ook bij machtige anderen, zoals de huisarta. Van hen mag verwacht worden dat zij zlch daarom ook meer laten leiden door hetgeen anderen van het betreffende gedrag vinden. Bijvoorbeeld van extern-georienteerden, die van mening zijn dat wooral de arts hun gezondheid en ziekte kan beinvloeden, mag aangenomen worden dat deze ook meer genelgd zijn de adviezen van de arts, zoals stoppen met roken, uit te voeren.

Dit betekent dait niet zonder meer mag worden verwacht dat ex een directe poaitlieve relatie bestat tussen een interne orientatie en gezondheidsen zlektegedrag, maar det intern-georienteerden hun gedrag wellicht meer baseren op de attitude ten opzichte van dit gedrag, terwijl de exterr-georlenteerden hun gedreg meer baseren op het oordeel ven anderen hierover. Uit thet voorgaande volgt dat de rol die de beheersingsorientatie speelt bij gezondheids- en ziektegedrag tweeledig kan zijn. De beheersingsorientatie kan een directe invloed hebben op deze gedragingen en de beheersingoorientatie kan ven invloed zijin op de wijze warop deze gedragingen tot stand komen.

Op welke wijze de beheersingsorientatie van invloed is op het gedrag heeft consequenties voor de GVo-praktijk. Bij een directe relatie is het van belang mensen meer bewust te maken van het feit dat ze zelf invloed kunnen uitoefenen op hun gezondheid. Indien de beheersingoorientatie van invloed is op de wijze warop gedrag tot stand komt, dus of het gedrag op basis van de attitude of op basis van hetgeen anderen menen tot stand komt, is het van belang intern- en extern-georienteerden op een andere wijze te benaderen on tot een gezonde leefwijze te komen.

\subsection{PROBLEEMSTELLING EN OPZET VAN ONDERZOEK}

Als voorlopige probleemstelling voor deze studie geldt de vraag of, en zo ja op welke wIjze, de beheersing sorientatie van invloed is op ziekte- en gezondheidagedrag. In hoofdstuk $5 \mathrm{zal}$ deze probleemstelling verder worden ultgewerkt in meer speclfileke vraagstellingen.

Nu zijn er in het verleden reads enkele studiea verricht naar de relatie tuasen de beheersingsorientatie en ziekte- en gezondheidsgedrag. Vaak echter met tegenatrijdige resultaten. Ten dele kan dit worden verklaard door het gebrulk van verachillende operationalisaties van het cancept. In hoofdstuk 2 en 3 zullen we hier uitvoerig bij stilstaan. Ten dele echter kunnen de tegenstrijdige en vaak teleurstellende resultaten verklaard warden door het gebruik van specifieke, homogene populaties. Effecten van 
mogelijk intervenlerende factoren, zoals leeftijd en social-econonische status zijn niet bekend, en hier wordt dus niet voor gecorrigeerd.

Mocht de beheersingsorientatie van invloed zijn op gezondheido- en zilektegedrag, dan zal dit in de eerste plasta voor een meer gezonde populatie gelden. Het gezondheldo- en ziektegedrag van zieke mensen zal door heel andere processen worden beinwloed. Mede omdat GVo zilch in de eerste plaats richt op het gezonde deel van de bevolking, is het hiler beschreven onderzoek opgenomen als onderdeel van een groter panel-onderzoek nar de subjectieve gezondheidstoestand, de gezondheidsopvattingen en de leefwijze van de Nederlandse bevolking. Voor dit panelonderzoek ziljn 882 personen geinterviewd, die oorspronkelijk een a-selecte steekproef uit de $\mathrm{Ne}$ derlandse bevolking in de leeftijdsklasse van 20 tot 65 jaar vormden. Dit gebeurde zowel in 1981 als in 1983 met behulp van een geatandaardiseerde vragenlijst. Deze onderzoeksopzet heeft verschillende voordelen. Allereerst kan een schasl geconstrueerd worden, die in verschillende populaties bruikbaar is, ondat ze op een heterogene populatie is gebaseerd. Vervolgens kan inzicht verkregen worden in verschillen tussen bepaalde groepen in de bevolking naar de beheersingsorientatie, en kan nagegaen worden of de relatie tussen beheersingsorientatie en gezondheido- en ziektegedrag beinvloed wordt door demograflische kenmerken, zoals leeftijd, sexe en sociaal-economische status. Tot slot kan de relatie tussen beheersingoorientatie en gezondheids- en ziektegedrag bestudeerd worden in een meer heterogene populatie den tot nu toe gebruikelijk is in onderzoek naar beheersingsorientatie.

Een dergelijke opzet kent uiteraard ook nadelen. Zo zullen samenhangen minder sterk zijn door het heterogene karakter van de populatie, terwijl niet alle wenselijk geachte variabelen opgenomen kunnen worden. Een belangrijker nadeel is echter, zosls later zal blijken, dat alleen relaties bestudeerd kunnen worden met bestaand ziekte- en gezondheldsgedrag.

\subsection{INDEL ING VERSLAG}

In hoofdstuk 2 wordt ingegaan op theoretiache abecten van de beheersingsorientatle. Aandacht wordt besteed an de soclale leertheorle warbinnen de beheersingsorientatie geplaatat moet worden, aan de afbakening van het concept in relatie met enkele andere concepten zoals machteloogheid, en aan de verachillende dimensies warin men de beheeraingaorientatie kan onderscheiden.

Vervolgens wordt in hoofdstuk 3 expliciet andacht besteed an de meting van het concept. Neast enkele keuzemomenten bij de meting, worden vier Engelstalige en enkele Nederlandstalige meetinatrumenten besproken. Hoofdstuk 4 betreft het literatuuroverzicht. Dit is beperkt gebleven tot studies omtrent de relatie tussen de beheersingsorientatie en het gezondheido- en ziektegedrag. 
In hoofdstuk 5 worden de vraggatellingen geformuleerd op basis van de voorgaende hoofdstukken, terwij 1 in hoofdstuk 6 de opzet, de respondenten en de variabelen van thet onderzoek besproken worden.

In hoofdstuk 7 gaan in op de door ons gebruikte operationalisatie van de beheeraingsorientatie. Behalve de betroumbaarheld van de drie geconstrueerde schalen, wordt de relatie wan deze schalen met demografische gegevens, gezondheidstoestand en (gezondheids)opvattingen besproken, teneinde gegevens te verkrijgen omtrent de validiteit van de drie schalen.

In hoofdstuk $B$ wordt ingegaan op de vreag of er een directe relatie bestait tusisen de beheersingaorientatie en het gezonidheids en ziektegedrag. Het gedragamodel van Ratter (1954) warnt hierbij het ulltgangspunt voor de analyses.

In hoofdstuk 9 komt de tweede centrale vraag van deze studie aan de orde, namelijk of de beheersingsorientatie invloed heeft op de wijze waarop het gezondhelda- en ziektegedrag tot stand kont. Hiervoor is gebruik genaakt van het model ven Fiahbein en Ajzen (1975).

Tot slot wordt in hoofdstuk 10 de studie afgeslaten met een samenvatting van de belangrijkste resultaten, de theoretische en de practische consequenties van het onderzoek en de aanbevelingen voor verder anderzoek. 
In de psychologische literatuur is de beheersingsorientatie geen onbekend begrip. Sinds Rotter's introductie van het concept (Rotter, 1966), is het aantal publicaties over de beheersingsorientatie gestegen tot plusminus 465 per far (vlgs. Psychological Abstracta). Toch zijn er zowel wat betreft de definiering, als wat betreft de meting nogal wat onduidelijkheden. Vandar dat we in dit hoofdstuk zullen ingaan op de betekenis van het concept en de dimensies die men er aan kan onderscheiden. Voor een goed begrip van de beheeraingsorientatie is het echter nodig het oorsponkelijke theoretische kader te kennen war de beheersinggorientatie uit is voortgekomen. Daarom zullen we eerst ingaan op de socilale leertheorie. In hoofdstuk 3 zal vervolgens aandacht worden besteed aan de meting van het concept.

\subsection{DE SOCIALE LEERTHEORIE}

Om gedrag te kunnen verklaren zijn diverse theorieen ontwikkeld. Globaal. zou men een onderscheid kunnen maken tussen theorieen welke gedrag zien als een resultante van voornemelijk persoonlijke factoren (zoals de cognitieve theorieen), en theorieen welke gedrag zien als een resultante van situationele- of angevingsfactoren (zoals de stimulus-responae theorieen). Dasrnast zijn er nog theorieen welke gedrag zien als het resultaat van de interactie tussen het individu en de omgeving. De aociale leertheorie van Rotter (1954) behoort tot de latstgenoende theorieen. Met zijn theorie probeert Rotter de stimulus-response theorieen en de cognitieve theorleen te integreren. Gedrag kont volgens hem tot atand uit de wisselwerking tussen persoonlljke en situlionele factoren.

Uitgangspunt van de sociale leertheorie is dat een individu in elke altuatie verschillende gedragsmogelijkheden heeft. Bijvoorbeeld een student die de volgende dagl een examen heeft, kan 'a avonds nog gaan studeren, hij kan naar een feest gaan, of zich op een andere wijze ontspannen. Aan de hand van de prioriteit, of in termen van Rotter de gedragspotentie, zal hij een keuze maken uit deze gedragomogelijkheden. Deze prioriteit of gedragspotentie wordt bepaald door twee factoren. Allereerst de werwachting van het individu, welk gevolg het gedrag zel hebben (de verwachting genoend). Bijwoorbeeld de student kan de verwachting hebben, dat $h I_{j} j$ door 's avonds nog enkele artikelen door te kijken, zijn kangen on te alagen vergroot. Vervolgens is van invloed welke warde het individu aen het ge- 
volg (of de bekrachtiging) hecht (bekrachtigingswaarde). Dus in welke mate vindt de student het belangrijk voor het examen te silagen? Aan de hand van de werwachting en de bekrachtigingswaarde kan voor elke gedragamogelijkheid een prioritelt aangebracht worden. Cedrag, warvan het individu verwacht dat het een gewenste bekrachtiging oplevert, heeft hierbij een hogere prioritelt dan gedrag met een verwachte ongewenste bekrachtiging. Het gedrag met de hoogste prioriteit zal vervolgens uitgevoerd worden. Dit betekent dat het individu in een situatie dat gedrag zel tonen, warvan hij $/ z_{1}$ verwacht dat het de meest gewenste bekrachtiging tot gevolg heeft.

Hierbij moet rekenung worden gehouden met het feit dat per situatie de prioriteit van gedrag ofwel de gedragspotentie kan verschillen. Hetzelfde geldt uiteraard voor de verwachting (ontrent de bekrachtiging) en de bekrachtigingawaarde. Per situatie kan de student van mening verschillen over de verwachting dat het ' $s$ avonds studeren nog effect heeft op het al of niet slagen, terwijl ook de waarde die hij hecht an het slagen per examen kan verschililen. Zowel de gedragspotentie, de verwachting als de bekrachtigingswarde zijn dus situlatie-afhankelijk. In zijn oorspronkelijke beschrijuing van de sociale leertheorie beperkte Rotter zich tot deze drie situatie-afhankelijke variabelen: de verwachting plus de bekrachtigingawarde bepalen de gedragapotentie op basis warvan het individu een keuze maakt uit diverse gedragmogelijkheden.

In latere publicaties breidt Rotter (1966; Rotter e.a., 1969, 1972) zijn model verder uit met een situatie-onafhankelijke variabele. Gedrag wordt niet alleen bepald door situationele factoren, maar ook door hetgeen het individu uit vroegere (soortgelifke) situaties heeft geleerd. Dit noent Rotter de gegeneraliseerde verwachting. Verwachtingen generaliseren volgens Rotter van een specifieke situatie nar een serie van situaties, welke door het individu als soortgelijk worden ervaren. Een gegeneraliaeerde verwachting is dus een aangleleerde verwachting, die gebaseerd is op vroegere ervaringen in soortgelljke situaties, en die op basis van nileuwe ervaringen aangepast of versterkt kan worden.

Eerder hebben we gezllen dat de gedragspotentle bepalald wordt aan de hand van de verwachting en de bekrachtigingswararde. De hier genoende verwachting is de resultante van enerzijds een specifieke verwachting, welke bepaeld wordt door ervaringen met dezelfde situatle, en anderzijds door de gegeneraliaeerde verwachting. On aan te geven welke inwloed beide op de ulteindelijke verwachting hebben geeft Rotter de volgende formule:

$\mathrm{Eg}=\mathrm{f}\left(\mathrm{Es} * \frac{\mathrm{GE})}{\mathrm{Na}}\right.$

De uiteindelijk verwachting ( $\mathrm{Es}_{s}$ ) wordt dus bepaald an de hand van enerzijds de specifieke verwachting (Es') en anderzijds de gegeneraliseerde verwachting (GE) gedeeld door het antal vroegere ervaringen met die specifieke situatie (Ns). Naarnate men meer ervaring met een bepaalde situa- 
tie heeft, zal men zich dus minder laten leiden door gegeneraliseerde verwachtingen.

Voor de bekrachtigingswarde zou men een soortgelijke redenering kunnen opbouwen. Naast een situatie-afhankelijke waarde zou men aok een aituatie-onafhankelijke warde kunnen onderscheiden. Ofschoon Rotter zich realiseert dat "often reinforcements values have considerable stability across both situation and time" (Rotter e.a., 1972, p.18), maakt hij zelf dit onderscheld niet. Dok Janssen en Voestermans (1978) komen in hun onderzoek tot de conclusie dat een dergelijk onderscheid slechts beperkte waarde heeft. Een algemene waardenorientatie doet niet onder voor een specifleke orientatie. Vandaar dat in de in figuur 2.1 weergegeven samenvatting van Rotter's model de bekrachtigingswaarde niet verder is opgesplitst naar een gegeneraliseerde en een specifieke bekrachtigingswaerde.

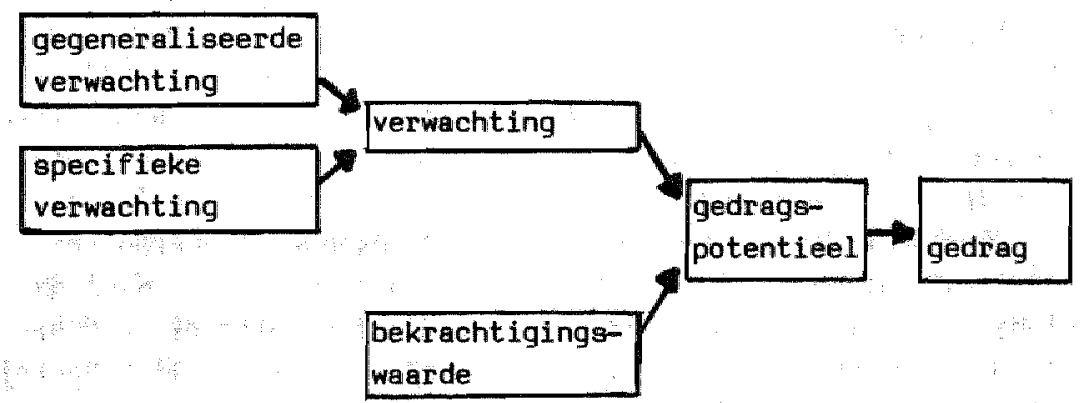

Fig. 2.1 De sociale leertheorie schematisch weergegeven.

\subsection{DE BEHEERSINGSORIENTATIE}

In thet voorgaende hebben we gezien dat Ratter naast een altuatie-specifieke verwachting ook een gegenerallseerde verwachting onderscheidt. De beheersingsorientatile is een voorbeeld wan een dergelijke gegeneraliseerde verwachting.

Bekend is de ideal-typische lindeling die Rotter maakt op basls van de beheersingsorientatie. Hij maskt een anderscheid tussen peraonen die intern en personen die extern georienteerd $z \mathbb{1} j n$. Intern-georienteerden $z \mathbb{1} j n$ pereonen die werwachten dat ze alles zelf in de hand hebben, terwilfl extern-georienteerden het idee hebben dat met name externe zaken zoals toeval, machtige anderen of het noodlot, hun leven beheersen.

Aan de hand van de plaats van de beheersingsorientatie binnen de soclale leertheorie en de relatle met enkele, vaak als synoniem voor de beheersingsorientatie gebruikte concepten, zullen we in deze paragraaf toewerken naar een werdere afbakening van de beheersingsorientatie. 


\subsubsection{DE BEHEERSINGSORIENTATIE BIMNEN DE SOCIALE LEERTHEORIE}

Woor een julbte plaatsbepaling binnen het model van Rotter moet een onderscheid worden gemaakt tusaen een tweetal soorten gegeneraliseerde verwachtingen, nameli.jk de gegeneraliseerde verwachtingen ontrent de bekrachtlging (CER) en de prableemoplossende werwehtingen (GEP).

Bif de gegeneraliseerde verwachting ontrent de bekrachtiging heeft er een generallaatie plaats gevonden over de bekrachtiging. Een voorbeeld van een dergelijke verwachting ig de verwachting van een student dat hif door hard te werken altijd slaagt voor een examen. Deze verwachting kan nog verder generallseren over andere situaties. Bijvoorbeeld dat hij verwacht dat hij door hard te werken meestal succes zal hebben in zijn leven.

Bi.j: de probleemoplossende gegeneraliseerde verwachting is de generalisatie niet gebaseerd op de bekrachtiging, maar op andere aspecten van de situatie. Als voorbeeld van een dergelijke verwachting noemt Rotter (1975b) het interpersoonlijk vertrouwen. De persoon verwacht in uiteenlopende situaties, ongeacht de bekrachtiging, dat hilj anderen kan vertrouwen, of juist niet kan vertrouwen. De mate maarin men anderen vertrouwt zal het uitelndelijke gedrag beinvloeden.

Een ander voorbeeld van een probleemoplossende gegeneraliseerde verwachting is de beheersingsorientatie. Hoewel deze ook lets zegt over de bekrachtiging, is het geen gegeneraliseerde verwachting omitrent de bekrachtiging. De beheersingsorientatie zegt namelijk iets over de beheersing van de bekrachtiging. Het geeft aan wie of wat het verkrijgen van de bekrachtiging kan beinvloeden, en niet of een dergelijke bekrachtiging inderdaad zal valgen op het gedrag. De verwachting dat men altijd succes heeft, is een voorbeeld van een gegeneraliseerde verwachting omtrent de bekrachtiging, aangezlen de verwachting alleen betrekking heeft op het al of niet verkrijgen van de bekrachtiging. Echter de werwachting dat men succes yoornamelijk aen zichzelf (eigen gedrag) of aan geluk of toeval te danken heeft, is een woarbeeld van de beheersingsorientatie. Het kenmerkende onderscheid tussen de beheersingsorientatie ren de gegeneraliseerde verwachting ontrent de bekrachtiging is dus, dat de eerste betrekking heeft op de beheeraing van de bekrachtiging, terwijl de tweede betrekking heeft op het al of niet volgen wan de bekrachtiging op het gedrag.

Simenvattend kunnen we zeggen dat de beheersingsorientatie binnen de sociale leertheorie tot de gegeneraliseerde verwachtingen behoort. Belangrijk hierbij is dat de beheersingsorientatie geen gegeneraliseerde verwachting omtrent de bekrachtiging is, maar behoort tot de categorie probleemoplossende verwachtingen.

Uit deze plaatabepaling is ook af te leiden onder welke voorwasrden en in welke mate de beheersingaorientatie het uiteindelijke gedrag beinvloedt. In paragraaf 2.4 zullen we dit verder uitwerken. Eerst zullen we echter aan de hand van enkele andere concepten het begrip beheersingsorientatie verder afbakenen. 


\subsubsection{DE BEHEERSINGSORIENTATIE EN AANVERWANTE CONCEPTEN}

Op basis van het voorgaande is de beheersingsorientatie te definieren als de gegeneraliseerde verwachting omtrent de beheersbarheid van de bekrachtiging. Uitdrukkelijk wordt hier de term beheersbarheld gebruikt en niet de tern oorzakelijkheid, aangezien beide een verschillende betekenis kunnen thebben. Zo moet de oorzaak van een griep allijd gezocht morden bij een virus, maar men kan wel een verschillende menling hebben over de vraag in welke mate men het krijgen van een griep kan beinvloeden ofwel beheersen. Aangezien het bij de beheersingsorientatie nilet gaat om de vraag welke oorzaak ten grondslag ligt an een bepaalde bekrachtiging, maar in hoeverre het gedrag of externe factoren de bekrachtiging beinvloed heeft, preferen we hier de term beheersbarheid boven de term oorzakelijkheid.

Verder hebben we in het voorgaande reeds apgemerkt dat de beheersingsorientatie niet verward mag worden met de gegeneraliseerde verwachting ontrent de bekrachtiging, zoals de verwachting dat men altijd succes heeft.

Behalve dit onderscheid zljn er nog een aantel concepten die ogenschijnlijk wel, op de beheersingaorientatie lijken, maar welke op $z^{\prime} n$ minst theoretisch van de beheersingsorientatle moeten worden onderscheiden. In deze paragraaf zullen we achtereenvolgens kort ingaan op "locus of causality" (De Charms, 1968), "self-efficacy" en "outcome-expectations" (Baindura, 1977), en uitgebreider op het concept machteloosheid.

Het concept "locus of causality", ook wel "personal causality" genoemd, is geintroduceerd door De Charms (1968). Hij brengt hiermee een ideaaltypisch onderscheid aan tussen personen die het eigen gedrag als een keuze ervaren (de "origens" genoemd) en personen die het eigen gedrag ervaren als liets dat door externe factoren bepaald wordt (de "pawns" genoemd). Hoewel de beheersingsorientatie en de "locus of causiality" allebel betrekking hebben op de beheersing, is het voorwerp van de beheerging bij beide vergchillend. Bij de "locus of causallty" gaat het on de beheersing van het eigen gedrag, bij de beheersingaorientatie gaat het on de beheeraing van de bekrachtiging. Volgens De Charms (1981) blijkt uit onderzoek, dat beide concepten niet met lkaar samenhangen.

Twee andere termen die vaker genoend worden in relatie met de beheersingsorientatie zijn "gelf-efficacy" en "outcome-expectations" van Bandure (1977). "Self-efficacy" verwijst naar de opvatting van een individu dat hij of zij het vereiste gedrag met succes kan valbrengen, terwijl de "outcome-expectations" betrekking hebben op de verwachting dat op het gedrag daedwerkelijk de bedoelde bekrachtiging volgt. De "outcome-expectations" komen dus overeen met hetgeen Rotter de (gegeneraliseerde) verwachting ontrent de bekrachtiging noemt. Het concept "self-efficacy" komt echter, wellicht ten onrechte, niet woor in de aociale leertheorie van 
Rotter. Rotter gati ervan uit dat een persoon, gegeven de situatie en gegeven zijn of haar gedragamogelijkheden, komt tot een keuze voor het gedrag. warvan hij of $21 j$ verwacht dat het de meest gewenste bekrachtiging oplewert. In tegenstelling tot fatter gat. Bandura echter niet uit van de verschlllende gedragamoge 1 jkheden, mas van de gewenste bekrachtuging. Volgena Bandura zoekt het individu bij een bepaalde gewenate bekrachtiging het verelete gedrag. In dat geval is het echter relevant of het in dividu van mening is het vereiste gedrag met succes te kunnen volbrengen, hetgeen Bandura met de term "gelf-efficacy" aangeeft.

De voorgaande concepten laten zich san de hand van het volgende schema (zie flg. 2.2) onderscheiden.

\begin{tabular}{|l|l|l|} 
& beheersbaarheid & bereikbaarheid \\
\hline gedrag & $\begin{array}{l}\text { locus of eausality } \\
\text { (De Charms, 1968) }\end{array}$ & $\begin{array}{l}\text { self-efficacy } \\
(\text { Bendura, 1977) }\end{array}$ \\
\hline bekrachtiging & $\begin{array}{l}\text { beheersingsorientatie } \\
\text { (Rotter e.a, 1962) }\end{array}$ & $\begin{array}{l}\text { outcome-expectations } \\
\text { (Bandura, 1977) }\end{array}$ \\
\hline
\end{tabular}

Fig. 2.2 Overeenkomsten en verschillen van de vier concepten.

In dit schema komen de verschillen en de avereenkomsten van de vier concepten tot uitdrukking. De "locus of causality" en de "self-efficacy" hebben allebei betrekking op het gedrag. De eerste zegt lets over de beheerabaarheid van het gedrag, terwijl de tweede lets zegt over het al of niet ten uitvoer kunnen brengen van het gedrag. De beheersingsorientatie en de "outcome-expectations" hebben gemeen dat ze beide betrekking hebben op de bekrachtiging, warbij de eerste weer lets zegt over de verwachtte beheersbarcheid van de bekrachtiging, terwijl de tweede betrekking heeft op de verwachting ontrent de bekrachtiging.

Tot zover hebben we het concept beheersingsorientatie kunnen afbakenen doar aan te geven wat er wel en wat er niet onder verstaan moet worden. Tot sot willen we wat uitvoeriger stilsteen bij een concept dat vaak als synoniem la gebrulkt voor de beheersingsorientatie, en juist daardoor de theorievorming omtrent de beheergingsorientatie heeft bemoeilijkt, name$11 \mathrm{jk}$ het concept machteloosheid.

Historiach gezien is de relatie tussen belide concepten niet onbegrijpe11jk. Rotter heeft namelijk samen met een van de belangrijkste figuren 
uit de vervreemdingsliteratuur, Melvin Seeman, zijn "Locus of controll. scale" ontwikkeld. Deze schaal werd door Rotter gebruikt on de beheeroingsorientatie te meten, terwijl Seeman dezelfde schal als meetinstrument voor machteloosheid gebruikte. Seeman's definitie wan machteloosheld is dan ook vrifwel Identiek an Rotter's definitie wan de beheersingoorientatie (Seeman, 1959).

In een poging beide concepten te onderscheiden stelt Seeman (1959), dat machteloosheid met name betrekking heeft op meer socio-politieke gebeurtenissen, op de relatie van de mens met de hogere sociale orde. Dit zou betekenen dat machteloosheid en beheersingsorientatie identieke concepten zijn, welke alleen naar gelang de aard van de bekrachtiging verschillend gebruikt moeten worden. Bij socio-politieke gebeurtenissen zou men moeten spreken van machteloosheid, terwijl bij meer persoonlijke gebeurtenissen men het concept beheersingsorientatie zou maeten gebruiken. Fen weinig bevredigend onderscheid, moet men helass zeggen.

Een zinvoller en essentieler onderscheid tussen beide concepten is af te leiden uit de definitie die Heunks (1973) geeft van machteloosheid: machteloosheid is het ontbreken, het onduidelijk of onaranvaardbaar $\mathbf{Z I j}$.jn van de middelen an bepaalde doelen te bereiken. Verder stelt hij dat machteloosheid een subjectief onvoldoende bereikbaarheid wan doeleinden 1s. Aan de hand van deze omschrijwing kunnen een drietal voorwarden geformuleerd worden waaraan voldaan moet worden, wil er sprake zijn van machteloosheid. Met behulp van deze voorwaarden zullen we het verschil tussen machteloosheid en de beheersingsorientatie duidelijk maken. Deze voorwaarden zijn:

1. Het individu moet een bepaalde bekrachtiging willen verkrijgen.

2. De middelen voor deze bekrachtiging moeten ontbreken, onduidelijk zijn of onaanvaardbaar zijn.

3. Het individu moet invloed willen uitoefenen.

De eerste woorwarde spreekt voor zllch, en komt overeen met de bekrachtigingswarde uit de sociale leertheorie. Toch moet deze voorwarde niet over het hoofd worden gezien, omdat volgens de sociale leertheorle gedrag pas tot stand kont als de bekrachtiging gewenst is.

De tweede voorwarde is cruciaal. Volgens Rotter wordt de beheersing van de bekrachtiging toegeachreven an het eigen gedrag of an externe factoren. Beide kunnen opgevat worden als middelen om bepaalde doelleinden (bekrachtigingen) te bereiken. Volgens de tweede voorwaarde zal er pas aprake zijn van machteloosheid als deze middelen ontbreken, onduidelijk zijn of onaanvaardbaar zijn. Dit betekent dat, in tegenstelling tot Seeman's opvatting, er bij een externe beheeraingsorientatie niet zonder meer sprake is van machteloosheid. Pas ala deze externe fectoren (middelen) als onduidelijk of onaanvaardbaer opgevat worden, kan dit volgens de tweede voorwaarde leiden tot machteloosheid. Antonovsky (personal communication, 1983) verwoordde dit als volgt: "Aan mijin gezondheld ken ik zelf weinig doen, maar ik heb drie goede vrienden, aan wie ik mijn ge- 
zondheld wolledig toevertrouw; namelijk mijn wrouw, mijn arts en God". Duidelijk is det Antonovsky aan externe factoren de beheersing van zijn gezondheid toeschrijft, hetgeen we een externe beheersingsorientatie noemen. Uyt niets blijkt echter dat hier sprake is machiteloosheld.

Rothbaum e.a. (1982) gaan in dit kader nog een stap verder. ZiJ atellen dat in de beheeraing-Literatuur tot nu toe alleen aandacht is geweest voor de controle die men zelf, door middel van het eigen gedrag, over gebeurtenissen kan hebben. Dus alleen voor de interne beheersing of, zoals zilj dit noemen, de primaime beheersing is belangstelling geweest. Toch kan men ook op andere wijze den door middel van het eigen gedrag controle hebben op gebeurtenisaen. Zo kan men op indirecte wijze zijn gezondheid beheersen, door bijwoorbeeld de externe belinwloeders zoals de partner, de arta, en God te vriend te houden. Deze vorm van beheersing noemen Rothbaum e.e. secundaire beheersing. Bij primaire beheersing past het individu de situatie an zichzelf aan. Bij secundeire controle past het individu zlchzelf aan an de situatie. Dit laatste kan volgens Rothbaum e.a. (1982) op een viertal wijzen. Allereerst door de elgen behoeften op een leger niveau te brengen in situaties, warvoor men slechts beperkte vaardigheden heeft (predictieve beheersing). Verder kan men de beheersing toeachrijven aan kans of geluk (illusoire beheersing) of machtige anderen ("vicarlous control"). Bij 111 usoire beheerging bereikt men een vorm van beheersing door zichzelf te omschrijven als lemand die altijd geluk heeft, of door met behulp wan rituelen het geluk gunstig te stemmen. Bij "vicarious control" verkrijgt men beheersing door zich te vereenzelvigen met machtige anderen, en/of door deze te vriend te houden. Tot slot geven de drie vaorgaande vormen van secundaire beheersing betekenis aan anders onbeheerabare ervaringen. De vardigheld om gebeurtenissen zodanig te interpreteren dat men ze later begrijpt en accepteert noemen Rothbaum e.a. interpretatieve beheersing.

Uit het voorgaende wordt duidelijk dat een externe beheeraing niet zonder meer opgewat mag worden als een synoniem voor machteloosheid. Een externe beheerbingaorientatie kan zelfs een vorm van (secundaire) beheersing zijn. Pas als deze onaanvaardbaar of onduidelijk is voor het individu, kan dit leiden tot machteloosheid.

Dok een interne beheersing sluit het aanwezlg zijn van machteloosheid niet ult. Evenals pergonen kunnen ook situaties verschillen in de mate warin ze intern dan wel extern beheergt kunnen worden. Personen met een duidelijke interne beheeraingsorientatie, zullen in situaties, warin er geen sprake kan zijn van een interne beheersing, geen middelen voorhanden vinden om de wereld aan henzelf aan te passen. Voor hen geldt dus dat de middelen ontbreken of onduide $11 j k$ zijn, hetgeen volgens de tweede voorwarde ook kan leiden tot machteloosheid.

Machteloosheid voortkamend uit een externe of voortkomend uit een interne beheersingsorientatie kan echter een verschillend effect hebben. Dit wordt duidelij $\mathrm{k}$ aan de hand van het psychologisiche equivalent van machteloosheid, namelijk hulpeloosheid (Seligman, 1975). Abramsan e.e. (1978) 
maken een onderscheid in twee soorten hulpeloosheid: unlversele en persoonlijke hulpeloosheid. Als een individu een bepalde situatie opvat als oncontroleerbaar en dit toeschrijft aan persoonlijke kenmerken, bijvoorbeeld aan een gebrek aan juiste vaardigheden, dan noemt Abramson dit persoonlijke hulpeloosheid. Vat een individu de oncontroleerbare situatie op als miet typisch voor zijn gebrek aan vaardigheden, maar als een voor (vrijwel) iedereen oncontroleerbare situatie, dan spreekt hij van universele hulpeloosheid. De persoonlijke hulpeloosheid is dus het gevolg van een interne attributie, terwijl de universele hulpeloosheid een gevolg is van een externe attributie. Aangezien intern-georienteerden meer geneigd zijn interne attributies te maken, zullen zij bij faalervaringen eerder een persoonlijke hulpeloosheid ervaren, terwijl extern-georienteerden dan eerder een universele hulpeloosheid zullen ervaren. Dit onderscheid is van belang, omdat het effect van beide vormen verschillend kan zijin. Als voorbeeld noemen Abramson e.e. (1978) dat persoonlijke hulpeloosheid in tegenstelling tot de universele hulpeloosheid, leldt tot een laag zelfvertiouwen. Dit betekent dat hulpeloosheid of machteloosheid bij interngeorienteerden eerder zal leiden tot een laag zelfvertrouwen dan bij extern-georienteerden.

De derde en laitste voorwarde die geformuleerd is om het onderscheid tussen machteloosheid en de beheersingsorientatie te verduldelijken - het individu moet invloed willen uitoefenen - zit reeds impliciet in de tweede voorwararde. Toch is deze hier nog eens expliclet als een aparte voorwaarde genoemd, on het belang ervan te benadrukken. Men moet daadwerkelijk de behoefte voelen on (primaire dan wel secundaire) beheersing te willen alvorens er sprake kan zijn van machteloosheid. De werwachting dat men weinig invloed heeft, heeft niets met machteloosheid te maken, indien men geen invloed wil uitoefenen. De persoon functioneert dan nar eigen maatataf bevredigend.

Samenvattend kunnen we zeggen dat de beheersingsorientatie een gegeneraliseerde verwachting omtrent de beheersbaarheid van bekrachtigingen is. In deze zin moet de beheersingsorlentatie onderachelden worden van concepten als "locus of causality", "self-efficacy", en "outcome-expectations". De interne en externe beheersingsorientatie kunnen opgevat worden als specifieke vormen van beheersing, welke in somige situaties wel en in endere niet gepast zij $\mathrm{j}$. In deze zin moet de externe beheeraingsorientatie ook niet opgevat worden als een symoniem voor machteloosheid. Er is pas sprake van machteloosheid als een gewenst doel niet berelkt kan worden, omdat de middelen ontbreken, onaenvaerdbaar zijn of onduldelijk zijin. Dit geldt zowel voor intern- als extern-georienteerden, hoewel het psychologisch effect van machteloosheid bij belide groepen werschillend kan ziljn. 


\subsection{DE DIMENSIONALITEIT VAN DE BEHEERSTNGSORIENTATIE}

\subsubsection{TNLEIOING}

Vanef de eerate onderzokken over de beheeraingsorientatie heeft de dimenaionaliteit van het concept aterk in de belangstelling gestaan. Dorspronkelljk gingen Rotter e.a. bij de constructie van de Locus of Control Scale (zie bijlage 1 ) uit van een multi-dimenslonas construct. Echter op basis van een tweetal factor-analytische studies kwamen $z i j$ tot de conclusie dat het meetinstrument glechts eén dimensie bevatte (Rotter, 1966). Taen uit latere studies bleek dat het concept multi-dimensionaal was, verdedigde Rotter (2975a) z1jn oorspronkelijke conclusie met het argument dat in de loop der jaren de apvattingen binnen de maatschappij meer gedifferentieerd waren geworden. Prociuk (1977) kont echter tot een geheel andere verklaring. Hij bestudeerde een van de door Rotter (1966) aangehaalde factor-analytische studies (Franklin, 1963), en herhaalde op het oorapronkelijke materiaal de factor-analyse. Op basis hiervan kwam hil tot de conclusie dat Franklin's resultaat gebaseerd was op een four tieve interpretatie van de "common variance explained" . De eerate factor verklaarde geen $53 \%$ van de variantie, zoals Franklin beweerde, mar silechts 9\%. Het concept is dus in de loop der jaren niet veranderd van één- nat multi-dimensionaal, maar is nooit érn-dimensionaal geweest (Paulhus en Christie, 1981).

De vraag welke dimensies er onderscheiden kunnen worden in de beheersingsorientatie, behoort in eerste instantie een theoretische vrasg te zijn, aangezien een meetinstrument zodanig geconstrueerd kan worden, dat het een of meer dimensiea bevat. Verschillende auteurs (Rotter, 1975a; Lefcourt, 1976; Klandermans en Visser, 1983) benadrukken dan ook dat het weinig zinvol is ateeds weer opnieuw de multi-dimensionalitelt van het construct vast te stellen. Nieuwe dimensies zijn pas zinvol, als deze een theoretibche grondsigg hebben en als blifkt dat deze een specifieke verklaringawamde hebben. Een posthoc constructie van dimengles draagt wej$\mathrm{nig} \mathrm{bij}$ tot theorievorming (Klandermans en Visoer, 1985). Deze visie moet echter niet leiden tot het hernieuwd innemen van Rotter's oorsprankelijke standpunt. Hiertegen zijn op dit moment teveel theoretische en empirische ergumenten in te brengen.

Dver het algemeen wordt de beheeralngsorientatie onderscheiden naar vier goorten dimensieg. Deze zijn:

1. beheersende instantie, bijvoorbeeld de persoon zelf, de machtige anderen of het toeval,

2. bekrachtigingegebieden, bijvoorbeeld bekrachtigingen die betrekking hebben op politieke gebeurtenissen of op gezondheid,

3. aard van de bekrachtiging, namelijk positief en negatief, 
4. object van de beheersingsorientatie, namelijlk de persoon zelf en mensen in het algemeen.

Op ellk van deze soorten dimensies zullen we in de volgende subparagrafen ingean.

\subsubsection{BEHEERSENDE INSTANTIE}

Uit Rotter's omschrijvingen van de beheersingsorientatie blijkt dat hij een tweetal tegengestelde beheersende instanties onderscheldt: de persoon zelf (de interne beheersende instantie) en verder alle factoren buiten de persoon (de externe beheersende instantie). Hoewel hij verschillende externe beheersende instanties noemt, zools kans of geluk, het noodlot, machtige anderen en een te complexe wereld, onderscheidt hij deze verder niet. Hij voegt ze tesamen tot één externe beheersende instantie. Uit een studie met een asngepaste versie van Rotter's vragenlijst bleek echter dat de externe beheersende instanties onderling onderscheiden kunnen worden (Collins, 1974), hetgeen bevestigd werd in studles met andere beheersingsorientatie-vragenlijsten (Finch e.a., 1981; Levenson, 1973).

De vraag is of een verdere differentiatie van de externe beheersende instantie ook niet zilnvoller is. De verwachting dat bijwoorbeeld met name de arts de gezondheid beheerst zal wellicht tot een ander gedrag leiden dan de verwachting dat kans of geluk de gezondheid beheersen. Een van de eersten die een dergelijk onderscheid binnen de externe beheersingsorientatie aanbracht, was Levenson (1973). Zij kwam op basis van persoonlijke ervaringen (Levenson, 1981) tot de conclusie dat binnem de externe beheersingsorientatie een onderscheld gemaakt moest worden tussen beheersing door machtige anderen en beheersing door kans of geluk. Factor-analyse op een door har ontwikkelde vragenlijat leidde tot de arie beoogde dimensiles. In diverse studies 18 in de loop der jaren deze structuur bevestigd en tevens zinvol gebleken (Levenson, 1973, 1974, 1981; Hertke e.a., 1982; Walkey, 1979; Wallaton e.a., 1978; Wallston en Wallaton, 1981).

Een tweede vraag die gesteld kan worden nar aanleiding van Rotter's omschrijuing van de beheersingsorientatie, is of de interne en de externe (al dan niet gedifferentieerde) beheersingsorientatie wel opgevat mogen worden als de twee polen van een continuum of als twee of meer afzonderlijke dimensies. Met andere woorden hebben degenen die geen interne orientatie hebben noodzakelijkerwijs een externe orientatie?

Andriessen en Van Cadsand (1983) vinden bij factor-analyse van de door Andriessen (1972) vertaalde en enigszins aangepaste wragenlijst van Rotter, twee duidelijke factoren, te weten een factor met uitaluitend intern geformuleerde uitspraken en een factor met uitsluitend extern geformuleerde uitspraken. Dit wijst erop dat een interne en een externe orienta- 
tie twee vergchillende orientaties zijn. De interpretatie van deze factor-analyse wordt echter enigszins bemoeilijkt door het feit dat in de door Andriessen gebruikte, maar ook in de door Rotter ontwikkelde vragerlijat, de externe uitspraken zodanig geformuleerd zijn, dat deze eerder net cancept machtelaosheid meten dan een externe beheersingsorientatie (zle paragraef 3.2 .1 .1 ). In de vorige paragraf $z i j n$ we reeds uituoerig ingegaan op het verschil tussen beide concepten. De bevindingen van Andriessen en van Cadsand moeten dan ook worden opgevat als een onderscheid tussen de interne beheeraingsorientatie en machteloosheid en niet zozeer als een onderscheid tussen de interne en de externe beheersingsorientathe.

In de door Levenson (1973) ontwikkelde vrageniljst verwijzen de externe uitspraken niet naar machteloosheid. Daarom biedt deze lijst betere aanknopingapunten voor de beantwoording van onze vraag. Uit verschillende studies met deze $1 i j s t$ blijkt dat de beide externe beheersingsorientaties (machtige anderen en kans of geluk) wel onderling samenhangen (van .41 tat .60; Levenson, 1981), maar dat de interne beheersingsorientatie nauwelljks samenhangt met deze externe orientaties (van -.25 tot .19; Levenon, 1981). Hieruit is af te leiden dat de interne en de externe beheersingsorientatic afzonderlijke dimensies vormen. Dit is ook meer in overeensteming met de glangbare visie dat situaties multi-conditioneel zijn. Gebeurtenisigen worden niet beheerst door of ....... of ....... maar door en......... en........

Dat een interne en een externe orientatie onafhankelijk van elkaar zijn betekent ook dat er naast een interne en een externe orientatie een derde beheersingaorientatie mogelijk is, namelijk de overtuiging dat er in het geheel geen beheersing mogelijk is. In negatieve zin kan dit op machteloosheid duiden. In positieve zin kan dit worden opgevat als een vorm van secundaire beheersing, en wel als interpretatieve beheersing (Rothbaum e.a., 1982). Hoewel deze vorm van beheersing ook opgevat kan worden als een externe beheersingsorientatie, is het goed deze als een aparte vorn te onderache iden.

Samenvattend kunnen we zodoende concluderen dat de interne en de externe beheergingsorientaties van elkaar onderscheiden moeten worden, warbij het zinvol 19 gebleken de externe orientatie te differentieren naar meerdere externe beheersende instanties.

\subsubsection{BEKRACHTIGINGSGEBIEDEN}

Behalve naar de beheersende instantie laat de beheersingsorientatie zich ook onderscheiden mar diverse soorten bekrachtigingen. De eerste onderzoeken die hiertoe een aanzet gaven zijn van Mirels (1970) en Abramowitz
(1973). Mirels vond met de vragenlijst van Rotter twee factoren, namelijk 
een factor welke uitspraken amvatte betreffende gebeurtenissen uit de directe ongeving en een factor die betrekking had op politieke gebeurtenissen. Joe en Jahn (1973) en Reld en Ware (1973) kwamen tot vr jwel dezelfde bevindingen. Dat een dergelijk onderscheid ook zinvol 1s, bevestigde het onderzoek van Abramowitz (1973). Mij vergeleek de scores op de herpelman Palitical Activity Scale met de scores op de twee door Mirela onderscheiden factoren van Rotter's vragenlijst. Hieruit bleek dat politleke betrokkentheid wel door de politieke schaal, maar niet door de schaal die betrekking had op gebeurtenissen uit de directe ongeving, werd verklaard. Echter ook de totaal-score van Rotter's vragenlijst bleek de politieke betrokkenheid niet te verklaren.

Het onderscheiden van bekrachtigingsgebieden, zoals politieke gebeurtenissen en gebeurtenissen uit de directe omgeving roept de vraag op nasr de mate van generalisatie. Uit de sociale leertheorie volgt dat gegeneraliseerde verwachtingen kunnen varieren in de mate van generalisatie. Een specifieke verwachting heeft betrekking op bén specifieke situatie. Naarmate deze verwachting in meer situaties toepasbaar is neent de matie van generallsatie toe. Voor de beheeraingsorientatie geldt dit ook, angezien deze gedefinieerd is als een gegeneraliseerde verwachting.

De beheersingsorientatie kan dus zeer specifiek gemeten worden bijvoorbeeld ten aanzien van het stoppen met roken, wat algemener zoals ten aanzien van gezondheid, of zeer algemeen, dat wil zeggen betrekking hebbend op alle bekrachtigingen. Het zal duidelljk zijn dat naarmate men de beheersingsorientatie specifieker meet, deze ook een grotere voorspellende waarde krijgt, aangezien de beheersingsorientatie dan meer de specifieke verwachting benadert omtrent de beheersing in een specifieke situlatle. Zo wond Saltzer (1978) dat een door haar ontwikkelde Weight Locus of Control Scale een goede voorspeller was van het al of niet deelnemen aan een cursus voor overgewicht, terwijl een Health Locus of Control Scale (Wallston e.a., 1976a) en Rotter's vragenlijst geen significante verklaring gaven voor het wel of niet deelnemen aan de betreffende cursus. Een nadeel van een specifiekere beheersingsorientatie is echter dat het belang ervan ofneent, aangezien een specifieke orientatie minder generallaerende watrde heeft.

Samengevat kunnen we zeggen dat het zinvol is een onderscheid wan te brengen binnen de beheersingsorientatie nar diverse bekrachtigingsgebleden. Enerzijds ondat de beheersingsorientatie sterk kan verachillen per bekrachtigingsgebied, anderzijds omdat een meer specifieke behereraingaorientatie een beter voorspellend vermogen heeft dan een meer algemene beheersingaorientatie. 


\subsubsection{AARD VAN DE BEKRACHT IGIULG}

Een ander onderscheid dat van belang is voor de beheersingsorilentatie is net onderacheid tusaen positieve en negatieve bekrachtigingen. Hoewel Rotter stelt dat individuen met een interne beheersingsorientatie zich ook verantwoordelijk wolen woor negatieve gebeurtenissen, blijkt deze relatie complexer te zijn dan hij woorstelt.

Een positleve bekrachtiging is een bekrachtiging, welke het individu probeert te verkrijgen. Een negatieve bekrachtiging daarentegen probeert het individu te vermijden of te voorkomen. Bijwoorbeeld waardering zal men proberen te verkrijgen, angst zal men proberen te voorkomen. Beide typen bekrachtigingen vereisen dus verschillende gedragingen. De verwachting of men deze bekrachtigingen zelf kan beheersen, zal zodoende verschillen. Op basig van een antal atudies komt Gregory (1981) tot de conclusie dat een interne orientatie ten aanzien van positieve gebeurtenissen niets zegt aver een interne orientatie ten aanzien van negatieve gebeurtenissen. Beide interne orientaties moeten als aparte orientaties worden opgevat. Zo vond Mischel e.a. (1974) dat activiteiten die gericht zijn op het verkrijgen van gewenste bekrachtigingen beter worden verklaard door een interne beheersing van succesvolle ervaringen, dan door een interne beheersing van faalervaringen. Het ontwijken van vervelende consequenties bllek echter beter voorapelbar door een interne beheersing van faalervaringen. Verder vonden ook Ducette e.e. (1972) dat bij kinderen de beheeraingsorientatie ten aanzien van succeservaringen verschilde van de beheersingsorientatie ten aanzien van faalervaringen.

Opgemerkt moet worden dat de vele factor-analytische studies met Rotter's vragenlijst nooit geleid hebben tot een onderscheid tussen positieve en negatieve bekrachtigingen. Volgens een studie van Gregory (1981) moet dit echter verklaard worden uit het feit dat deze vragenlijst met name gericht is op negatieve bekrachtigingen.

Samenvattend kunnen we concluderen dat bij de beheersingsorientatie een onderscheild gemakt moet worden tussen positieve en negatieve bekrachtigingen, aangezien ten aanzien van beide de beheersingsorientatie kan verschillen.

\subsubsection{DBJECT VAN DE BEHEERSENDE INSTANTIE}

De beheersingsorientatie, zoals die tot nu toe is gebruikt, heeft betrekking op de beheersing door de persoon in kwestie zelf. Hij of zij verwacht dat de bekrachtiging beheerat wordt door het eigen gedrag of door externe factoren. Behalve deze verwachting zou men naar analogie van het onderscheid in persoonlijke en universele hulpeloosheid (Abramson e.a., 1978), ook een universele verwachting kunmen onderscheiden die be- 
trekking heeft op personen in het algeneen. Dus de verwachting van een individu dat personen in het algemeen beheersing hebben ower bekrachtigingen of dat deze bekrachtligingen beheerst worden door externe factoren. Een dergelijk onderscheld is gevonden door Gurin e.a. (1969; 1978) met behulp van een factor-analyse op de enigszins gewijzigde vragenlijst wan Rotter. De eerste factor - "Personal Control" genoend - bevatte alle uitspraken gesteld in de ik-vorm, terwijl de tweede factor - "Control Ideology" - gevornd werd door uitspraken in de men-vorm.

Hoewel dit onderscheid vaak in overzlchtoliteratuur (Lefcourt, 1976; Phares, 1976; Andriessen en Van Cadsand, 1983) genoiemd wordt, zijn er verachillende redenen am an de waarde ven dit onderscheid te twijfelen. Tot nu toe is dit onderscheid in geen enkel ander onderzoek omtrent de multi-dimensionaliteit van het concept gevonden. Lao (1970) bevestigt het onderscheid wel, maar maakt hierbij gebruik ven hetzelfde databestand als Gurin e.a. (1969). Coan e.a. (1973a) vonden met een zelf geconstrueerde vragenlijst zeven factoren, waarvan er vier voornamelijk betrekking hadden op uitspraken in de ik-vorm en twee op uitspraken in de men-vorm. Onduidelijk is echter of dit onderscheid toegeschreven moet worden aen vorm- of inhoudelijke verschillen.

Gurin e.a. (1978) zelf verklaren het feit dat tot nu toe niemand dit onderscheid heeft gevonden, door te stellen dat zij een andere factor-analytische methode gebruikt hebben. Bij gebruik van de door Mirels (1970) gebrulkte methode winden zij dezelfde factoren als Mirels, namelijk ékn welke betrekking heeft op gebeurtenissen wit de directe omgeving en cén welke betrekking heeft op politieke gebeurtenisaen. Aangezien de uitspraken in de $i k$-vorm samenhangen met meer persoonlijke gebeurtenissen en de uitspraken in de men-vorm samenhangen met politieke attitude en gedrag (Gurin e.a., 1978), is het niet ondenkbarar dat het gevonden onderscheid meer gebaseerd is op inhoudelijke gronden dan op de vorm van de uitspraken.

Om dit na te gaan hebben we in een eerder onderzoek 36 respondenten eenzelfide gezondheidsapecifleke beheersingsorientatie-lijst voorgelegd, beataande uit drie achalen, eermal in de $1 \mathrm{k}$-vorm en eenmal in de menvorm. Hieruit bleek dat de overeenkomstigle achalen bij de ik- en de menvorm onderling hoog correleerden $(.84, .91, .81)$, terwijl de schalen bij de $1 k$-vorm op gelijjke wijze onderling samenhingen, als de achalen bilj de men-vorm. Dit betekent dat tenminste voor de gezondheidsapecifieke beheersingsorientatie geldt dat de $i k$ - en de men-vorm geen verachillende soorten orientaties vormen. Aangenomen mag worden dat het door Gurin e.a. gevonden onderscheid waarschijnlijk niet aan vorm, maar aan inhoudelijke verschillen moet worden toegeschreven.

Hoewel op theoretische gronden een dergelijk onderscheid wellicht relevant is, moet op basis van het voorgaande betwijfeld worden of een dergelijk onderscheid bij de beheersingsorientatie feitelijk aanwezig is. 


\subsection{HET BELANG VAN DE BEHEERSINGSORIENTATIE}

Tot nu toe zijn we met name ingegaan op de betekenis van de beheersingsorlentatle. In deze paragraaf zal een geheel ander aspect besproken worden, namelijk in hoeverre theoretigch verwacht mag worden dat de beheersingsorientatie het uiteindelijke gedrag beinvlaedt.

We hebben reeds gezlen dat de beheersingsorientatie een gegeneraliseerde verwachting is. Zoals uit het wolgende zal blijken, geeft deze plaatsbepaling binnen de sociale leertheorile de grenzen aan van het verwachte effect van de beheeralingsorientatle op het uiteindelijke gedrag.

Eerder hebben we gezien dat de invloed van gegeneraliseerde verwachtingen op de uiteindelijke verwachting afhangt van het aantal vroegere ervaringen wan het individu met de situatie. Naarmate het individu meer ervaring heeft met een bepaalde situatie, zal de invloed van de gegeneraliseerde verwachtingen steeda kleiner worden. Het individu zal een meer uitgebalancererd gedragspatroon gaan volgen, dat specifiek is afgestemd op de situatie. Echter in siluaties waarmee het individu geen of weinig ervaringen heeft, zal het terugvallen op vroegere ervaringen in soortgelijke situaties. Met andere woorden alleen in nieuwe of ambique situatieg mag men aannemen dat gegeneraliseerde verwachtingen, zaals de beheersingsorientatie, de uitelndelijke verwachting beinvloeden.

Hierbij moeten we tevens rekening houden met het feit dat de beheersingsorientatie alechts eén van de gegeneraliseerde verwachtingen varmt.

Bavendien ia de warde, die het individu hecht an de bekrachtiging, van belang. Volgens de acciale leertheorie wordt het gedrag bepaald aan de hand van de verwachting ontrent de bekrachtiging en aan de hend van de waarde die hij of zi.j hecht aan de bekrachtiging. Indien een persoon de bekrachtiging niet relevant vindt zal hij of zij ook geen moeite doen on de betreffende bekrachtiging te werkrijgen. De beheersingsorientatie zal dus alleen invloed hebben op gedrag wanneer de verwachte bekrachtiging voor de persoon relevant is.

Op basia van het voorgaande kunnen we dus stellen dat - uitgaande van de sociale leertheorie - de beheersingsorientatie alleen van invloed is op gedrag indien er sprake is van nieuwe of ambigue situaties en indien de persoon de bekrachtiging bellangrijk vindt. Aangezien de beheersingsorientatie in die gevallen slechts eén van de determinanten var gedrag is, betekent dit dat de invloed van de beheersingsorientatie op gedrag een beperkte reikwijdte heeft.

\subsection{SAMENVATTING EN CONCLUSIE}

In dit hoofdatuk is voornamelijk ingegaan op de betekenis en de dimensionaliteit van de beheersingsorientatie. 
Op basis van het gestelde in dit hoofdstuk kunnen we de beheersingaorlentatie omschrijven als de verwachting die een individu heeft door wile of wat de bekrachtiging wordt beheerst, en in welke mate. In dit opzlcht moet de beheersingsorientatie ook onderscheiden worden van cancepten als gegenerallseerde verwachting omtrent de bekrachtiging, "locus of causality", "self-efficacy", en "outcome-expectations". Uitvoerig is ingegaan op het feit dat een externe orientatie niet identiek is aan machteloosheid. Machteloosheid is het gevolg van het ontbreken, onduidelijk zijn of onaanveardbaar zijn van de middelen on gewenste bekrachtigingen te verkrijgen.

Verder is in dit hoofdstuk angegeven dat het zinvol is het concept natar verschillende soorten dimensies te onderscheiden, zoals naar de beheersende instantie, naar het object van de beheersende instantie, en naar de bekrachtigingsgebieden. Nouw verwant hiermee is de mate van generalisatie. Naarmate de beheersingoorientatie specifieker is gericht op de situatie en de bekrachtiging zal deze meer invloed hebben op het uiteindelijke gedrag. Voorwaarde daarvoor is echter wel dat de situatie ambigue of nieuw moet zijn en dat de verwachte bekrachtiging gewenst 1s. De totole invloed van de beheersingsorientatie op gedrag heeft zodoende een beperkte reikwijdte. 
In de loop der Jaren is de betekenls van de beheersingsorlentatie onder Invloed van onderzoek en theoretische ontwikkelingen enigszins gewijzigd. Wiet meer central stal de vraag of het individu van mening is dat hij of zij zelf de bekrachtiging kan beheersen, maar wie of wat deze bekrachtiging kan beheeraen in in welke mate. Dientengevalge is ook de meting van het concept in de loop der jaren veranderd. Vandaar dat we hier een epart hoofdstuk asn wijderi.

Om enige orde in het grote antal meetinstrumenten van het concept (Rottex, 1966; Crandal1 e.a., 1965; Wallston e.a., 1976a, 1978a; Parcel en Meyer, 1978; Saltzer, 1978; Hill en Bele, 1980; Lefcourt, 1981a; Paulhus en Christie, 1981; Worell en Tumilty, 1981) aen te brengen zal in dit hoofdstuk eerat ingegean worden op de vraag op welke wijzen de beheersingiorientatie gemeten kan worden. Vervolgens worden een viertal meetinstrumenten welke voor deze studie relevant zijn nader besproken. Tot slot zal kort worden ingegaan op enkele Nederlandse beheersingsorientatie vragenlijaten.

\subsection{KEUZEMOMENTEN IN DE METING VAN DE BEHEERSINGSORIENTATIE}

Aam de hand van de in het vorige hoofdstuk onderscheiden, dimensies binnen de beheersingsorientatie kunnen naast de gebruikelijke criteria van betrouwbarheid en validiteit, een aantal keuzemomenten anngegeven worden woor de meting van de beheersingsorientatie.

\subsubsection{BEHEERSENDE INSTANTIE}

In het vorige hoofdatuk is aangegeven warrom de essentie van de beheeraingoorientatie nict de verwachting van een individu is in welke mate men zelf Invloed kan uitoefenen, maar de verwachting door wie of wat de bekrachtiging(en) beheerst worden en in welke mate. Dit betekent dat niet alleen een onderscheid gemaakt moet worden in een interne en een externe beheersingsorientatie, maar dat ook alle relevante - externe - beheersende instanties opgenomen dienen te worden. Nu is het praktisch gesproken onmogelijk om alle mogelijke externe instanties (van God tot en met de GG * GD) in een of meerdere schalen op te nemen, dus moet men een keuze ma- 
ken. Een zinvalle indeling van beheersende instanties lis de indeling van Levenson (1973) nair: de persoon zelf, de machtige anderen en de kans of het geluk. In specifleke siturties of bij specifleke bekrachtigingen kan het nuttig zijn een of meerdere externe beheersende instanties (bijvoorbeeld God) toe te voegen.

Aangezien uit diverse studies gebleken is dat de interne beheergingoorientatie onafhankelijk is van de externe beheersingsorientaties, moet elke orientatie met een afzonderlijke schaal gemeten worden. Een schaal voor de interne orientatie geeft uitsluitend informatie over de mate warin men vindt dat men zelf de bekrachtigingen kan beheersen. Zonder uitsluitsel te geven over de mate warin verwacht wordt dat externe instanties de bekrachtiging beheersen.

\subsubsection{BEKRACHTIGINGSGEBIEDEN}

Een ander belangrijk punt bij de operationalisatie van de beheersingsorientatie vormt de mate van generalisatie. Wit de sociale leertheorie is of te leiden dat de beheersingsorientatie kan varieren in de mate van generalisatie. Enerzijds kan de beheersingsorientatie zeer specifiek gemeten worden, zoals ten aanzien van het slagen voor een bepasld examen; anderzijds kan deze zeer algemeen gemeten worden, dus geldend voor wrijwel alle bekrachtigingen. Naarmate de beheersingsorlentatie specifieker gemeten wordt, is het verklarend vermogen groter. Echter een specifiekere beheersingsorientatie heeft wel de beperking dat de bruikbaarheid en de generaliseerbaarheid ervan geringer is. De mate van generalisatie vormt dus altijd een compromis tusien enerzijds het verklarend vermogen en anderzijda de zinvolheid. Vandaar dat er meetingtrumenten ontwikkeld zijn, die betrekking hebben op een bekrachtigingsgebled, dat w11 zeggen op aoortge11jke bekrachtigingen (bijwoorbeeld ten aanzien van gezondheid en ziekte). Aangezien de beheersingsorientaties ten aanzien van verachillende bekrachtigingsgebieden onderling kunnen verschillen en oums onafhankelijk van elkaar zijn (Mirels, 1970; Abramowitz, 1973), kan een werdere generalisatie tot problemen leiden.

Diverse auteurs zljn er daram toe overgegaan apecifieke beheeraingsorientatie-schalen te construeren welke betrekking hebben op éen bekrachtiglingagebled (Wallaton e.a., 1976a, 1978a; Saltzer, 1978; Hill en Bale, 1980; Worell en Tumilly, 1981; Lefcourt, 1981a). De resultaten hiervan geven voldoende steun om door te gaan met het ontwikkelen van bekrachtigings-specifieke schalen. Lefcourt (1981a) beschrijft zelfa en model aan de hand waarvan beheersingsorientatie-schalen geconstrueerd kunnen wor den. Iot nu toe hebben hij en zijn collega"s twee specifieke schalen ontwikkeld, namelijk een ten aranzien van prestatie en een ten aanzien van affiliatie. Op hun programma staen nog schalen ten aenzien van werk, hu- 
welljk, liefde, en affectie. Verder zijn bekrachtigings-specifieke schaLen ontwikkeld ten aanzien van alcoholgebruik (Worel1 en Tumilly, 1981), ten anzien van gezondheid en ziekte (Wallstan e.a., 1976a, 1978a), en ten asnzien van geestelijke gezondheld (Hill en Bale, 1980).

\subsubsection{AARD VAN DE BEKRACHTIGING}

Behalve naar de beheersende instantie en naar de bekrachtiging moet de beheersingiarientatie ook onderscheiden worden naar positieve en negatieve bekrachtigingen. Positieve bekrachtigingen wil men verkrijgen, negatieve bekrachtigingen probeert men te vermijden of te voorkomen. Waardering wil men verkrijgen en angst voorkomen of vermi,jden. Beide typen bekrachtigingen vereisen echter andere vaardigheden, zodat ook de verwachting ten aanzien van belide kan verschillen. Dit betekent dat men zowel voar de positieve als voor de negatieve bekrachtiging(sgebieden) afzanderlijke schalen dient te construeren. In feite is dit dus een specifieke ultwerking van hetgeen reeds geateld is in het voorgaande, aangezien ook daar is gesteld dat indien bekrachtigingen duidelijk verschillen, de beheeraingsorientaties niet alleen kunnen verschillen, maar ook onefhankelijk van elkaar kunnen zijn. Dit is ook aannemelijk voor gezondheid en zlekte. Gedragingen die nodig zijn on gezond te blijven of ziekte te voorkomen kunnen verschillend zijn van de gedragingen die nodig zijn om van een ziekte te herstellen. De eerste noemen we gezondheidsgedrag (bijvoorbeeld niet roken, matig alcoholgebruik en voldoende licheamsbeweging), de tweede noemen we ziektegedrag (bijvoorbeeld naar de dokter gaan, medicljngebruik en voldoende rust). Hoewel de bekrachtigingen gezond blifven en gezond worden, dus verschillende vaardigheden vereisen, la met twee gezondheidsgpecifieke vragenlijsten van Wallston e.a. (1976a, 1978a), waarin belde bekrachtigingen voorkomen, een dergelijk onderscheid met factor-analyse noait gevonden. Het is mogelijk dat personen de beheersing van beide bekrachtigingen op dit terrein op soortgelijke wiljze inschatten.

\subsubsection{OBJECT VAN DE BEHEERSENDE INSTANTIE}

In het vorige hoofdstuk is angegeven dat het onderscheid nas het object van de beheersingsorientatie (Gurin e.a., 1969, 1978) op zijn minst twijfelachtig 1s. Bij het verklaren van gedrag gaat het in eerste instantie om de verwachting van het individu aan wie of wat hij of $z i j$ de beheersing van de bekrachtiging toeschrijft, en niet om de verwachting van het 
individu aan wle of wat hij denkt dat anderen de beheersing van de bekrachtiging toeschrijven. Daarom lijkt het zinvaller bij de operationalisering van de beheersingsorientatie alleen het individu zelf als object te nemen.

\subsubsection{SAMENVATIING}

In het voorgaande zijn diverse keuzemomenten aangegeven bij de operationalisering van de beheersingsorientatie. Gesteld is dat een onderacheid gemaakt moet worden in interne en externe beheersende instanties, waarbij de externe instanties onderscheiden kunnen worden afhenkelijk van de vraagstelling. Verder kan de beheersingsorientatie al naar gelang de gewenste mate van generalisatie specifiek of algemeen gemeten worden. Hierbij moet rekening worden gehouden met het feit dat naarmate de beheersingeorientatie specifleker gemeten wordt, het voorspellend vermogen groter wordt, maar de algemene toepasbaarheid geringer. Hierbij dienen positieve en negatieve bekrachtigingen onderscheiden te worden. Tot slot is voorgesteld het individu zelf als object van de beheersingsorientatie te nemen.

Deze aanbevelingen en voorwaarden kunnen als volgt worden samengevat in de volgende "formule":

Kans beparlt aucces of
Ik bepar of ik mislukking heb met $\begin{aligned} & \text { verschillende } \\ & \text { bekrachtigings- } \\ & \text { gebieden }\end{aligned}$
Anderen bepalen
etc.

(Vrij naar Paulhus en Chrlatie, 1981)

Het deze formule zijn voor elk bekrachtigingsgebled alle mogelijke facetten van de beheeraingsorientatie vast te leggen. Voor elk facet moet een af zonderlijke gchael geconstrueerd worden.

\subsection{VIER ENGELSTALIGE MEETINSTRUMENTEN VAN DE BEHEERSINGSORIENTATIE}

In de vorige paragraaf $z i j n$ de ultgangapunten voor de operationalisering van de beheersingsorientatie angegeven. Zoals we reeds eerder hebben opgemerkt, zijn er in de loop der tijd diverse meetinstrumenten ontwikkeld; of uit onvrede met de reeds bestaande instrumenten of omdat men de beheeraingaorientatie specifieker wilde meten. Terecht merkt Lefcourt 
(1981c) in dit verband op dat een concept niet verward moet worden met het meetinstrument. Hetgeen Rotter"s oorspronkelijke vragenlijst meet is niet per definitie gelijk aen de beheersingsorientatie.

Voor onze atudie zijn een viertal vragenlijaten interessant. Enerzijda ondat $z i j$ een goed beeld geven van de ontwikkeling van het concept, anderzijda andat deze de meest gebruikte wragenlijsten zijn in onderzoek omtrent de relatie beheersingsorientatie en gezondheids en ziektegedrag.

Deze vragenlijsten zijn onder te verdelen naar twee algemene vragenlijsten, te weten Ratter's Locus of Control Scale (LOC) en Levenson's Multidimeneitonal Locus of Control scale (MLOC), en twee gezondheldsepecifieke vragenlijsten, beide van Wallston e.a., namelijk de Health Locus of Control Scale (HLOC) en de Multi-dimensional Health Locus of Control Scale (MHLOC). In het nu volgende zullen we nagaen in hoeverre deze lijsten de potientie hebben om de beheersingsorientatie te meten.

\subsubsection{ALGEMENE BEHEERSINGSORIENTATIE-VRAGENLIJSTEN}

\section{2 .1 .1 ROTTER'S LOCUS OF CONTROL SCALE}

Rotter's LOC is ontstaan uit een vragenlijat, welke in 1957 door Phares is ontwikkeld (vlgs. Rotter, 1966). Deze vragenlijst bevatte 13 extern geformuleerde en 13 intern geformuleerde items. De resultaten die James (1957, vlgs. Rotter, 1966) met een aangepaste versie verkreeg, waren dermate bemoedigend dat Rotter in aamenwerking met Liverant en Seeman subschalen ontwikkelde voor verschillende bekrachtigingsgebieden, zorls prestatle, genegenheid, en meer algemene socilale en politieke attituden. Na een eerste veraie van 100 items werd de 11 jst in verschillende fasen teruggebracht tot 23 forced-choice items, waaraan 6 filler-items werden toegevoegd. Van de oorspronkelijke opzet om voor verschillende bekrachtiglngsgebieden afzonderlijke subschalen te ontwikkelen, werd afgezien. Door acmmatie van de externe antwoorden wordt een totalscore verkregen. In bijlage 1 is deze lijat weerglegeven.

In diverse studies heeft Rotter (1966) de betroumbarheid van de vragen11.jst onderzocht. De interne betrouwbarcheid varieert van .61 tot.79, hetgeen voor een $11 j$ st met 23 items niet hoog is, terwijl de test-hertest betrouwbaarheden varieren van .83 ( 1 maand) tot .49 ( 2 maanden). Hoewel Phares (1976) stelt dat de relatie met sociale wenselijkheid soms wel en somi nlet gevonden wordt, geeft Rotter aan dat deze varieert tussen -.12 en -41 (een interne orientatie gaat samen met sociale wenselijkkeid). Een probleen met dergelijke vragenlijsten is altijd, dat onduidelijk is of aacialle wenselijkheid gerelateerd is aan het te meten concept of aan de vragenlijat. Met andere woorden: gedragen intern-georienteerden zich 
meer sociaal wenselijk of roept de wragenlijst lets op waardoor mensen meer aociaal wenselijke antwoorden geven. Met behulp van de theorie van "slgnal detectability" labt Schreiber (1980) zien dat aociale wenaelijkheid niet met het concept beheersingsorientatie samenhangt, maar juigt met de response bias van Rotter's LOC. Rotter"s LOC geeft dus een vertekening van de beheersingsorientatie door sociaal wenselijke antwoorden.

Behalwe een vertekening door sociaal wenselijke antwoorden, zijn en nog een aantal, meer fundamentele, kritiek-punten. Als eerste kan de vraag gesteld worden of de LOC wel het beoogde concept meet, zoals Klandermens (1983) zich terecht afvraagt. Eerder hebben we al gemeld dat in Rotter"s vragenlijst de extern geformuleerde itens meer machteloosheid dan externe orientatie weerapiegelien. Zo luiden de twee items met de hoogste correlatile met de totale schaal als volgt: "Vask heb $i k$ het gevoel dat ik weinig invloed heb op de dingen die mij overkomen" en "Wat betreft de belangrljkste zaken in de wereld, zijn de meesten van ons slachtoffer van krachten die we niet kunnen begrijpen, noch beheersen". Met name bij het tweede iten wordt expliciet verwezen naar machteloosheid. Men kan noch zelf de zaken die men belangrijk vindt beheersen, noch kan men de krachten die invloed hebben, begrijpen of beheersen. In termen van Rothbaum e.a. (1982) is hier geen sprake van primalre maax ook nilet van secundaire beheersing. Aangezien bij de LOC gebruik gemaakt wordt van forced-choice items, is het niet mogelijk de interne orientatie en machteloosheid als twee aparte schalen te gebruiken. Respondenten moeten steeds een keuze maken tussen een intern en een extern geformuleerd item. Uit de diverse onderzoeken, waarbilj de forced-choice items veranderd zijn in afzonderlijke items met een Likert-antwoord schaal (Collins, 1974; Kleiter, vlgs. Lefcourt, 1976; Andriessen en Van Cadsand, 1983) blijkt dat de interne items steeds een afzonderlijke factor vormen nasst de externe (of machteloosheid) items. Een somscore op de LOC is dus een optelling van twee onafhankelijke concepten, zodat de betekenis die men hieraan moet toekennen onduidelijk $1 \mathrm{~s}$.

Een ander probleem is dat bijy de LOC geen onderscheid is gemalkt naer bekrachtigingsgebleden. Ten onrechte kwam Rotter tot de conclusie dat de LOC slechts eén algemene factor bevatte (Prociuk, 1977). Diverae auteuri (Mirels, 1970; Abramowitz, 1973, Joe en Jahn, 1973; Reid en Ware, 1973) zijn namelijk tot de conclusie gekomen dat binnen de LOC een onderscheld gemaakt moet worden naar twee bekrachtigingsgebleden; te weten politieke gebeurtenissen en gebeurtenissen uit de directe ongeving. Rotter'a LOC bevat dus twee soorten beheersingsorientaties die van elkaar onderscheiden moeten worden, omdat ze onifhenkelijk van elkaer zljin.

Samenvattend kunnen we concluderen dat een LOC-score door zowel de verwevenheid met het begrip machteloosheid, als door het samenvoegen van onafhankelijke bekrachtigingsgebieden, een onduidelijke betekenis heeft. De interne betrouwbaarheid ervan is wellicht hierdoor laag, terwijl de LOC ook een sociaal-wenselijke antwoordtendens uitlokt. 


\subsubsection{LEVENSON'S MLOC}

Op basis van persoonlijke ervaringen kwam Levenson tot de conclusie dat bunnen de externe beheersende instantie een onderscheid gemaakt moest worden tusgen machtige anderen en kans of geluk. Factoranalyse op een door haar ontwikkelde vragenlijst leverde de drie beoogde factoren op, namelijk een lnterne, een machtige anderen, en een kans of geluk beheersingsorientatie (Levensan, 1974). Dieze structuur werd door Levenson (1973), Walkey (1979), en Buttler en Burr (1980) bevestigd.

De MLOC bevat 24 Likert-items en wel voor elke scheal acht. Voorbeelden van dergelijke ltems zijin: "Of ik wel of niet een auto-ongeluk krijg, hangt voornamelijk af van hoe goed $1 k$ rijd" (interne beheersingsorientatie), "of ik wel of niet een auto-angeluk krijg, hangt voornamelijk af van de andere bestuurders" (machtige anderen orientatie), "Df ik wel of niet een auto-ongeluk $\mathrm{krijg}$, is voornamelijk een kwestie van geluk" (kans-orientatie). In tegenstelling tot Rotter's LOC is de MLOC beperkt tot items die uitsluitend betrekking hebben op gebeurtenissen, ult de directe ongeving. Items die betrekking hebben op politieke gebeurtenissen komen in de MLOC niet voor.

De interne betrouwbarheden, berekend met behulp van Kuder-Richardson bedroegen .64 voor de interne orientatie-schaal (I), .77 voor de machtilge anderen-gchaal (P), en .78 voor de kans-schaal (C) (Levenson, 1974). Soortgelijke betroumbariheden werden gevonden door Levenson (1973), Wal1ston e.a. (1978a), en Walkey (1979). De split-half betrouwbaarheden bedroegen .62 (I), .66 (P) en .64 (C). De door Walkey (1979) gevanden split-half betrouwbarheden zijn iets hoger. 0ok de test-hertest betrouwbaarheden zijn goed; bij een periode van 7 weken bedroegen deze .66 (I), .62 (P), en .73 (C) (Lee, vigs. Levenson, 1981), terwijl Zukotynski en Levenson ( $v$ lgs. Levenson, 1981) met een vereenvoudigde lijst, test-herteat betrouwbarheden vonden van .85 (I), .91 (P), .65 (C) (tijdgduur on bekend). De samenhang met sociale wenselijkheid is laag, en varieert tussen -10 en .11 (Levensan, 1981). Walkey (1979) vond iets hogere samenhangen, namelijk .19 (I), -.20 (P') en .09 (C).

De structuur tussen de drie schalen is redelijk stabiel. Zoals verwacht mocht worden is er een significante samenhang tussen de beide externe (Pen $C-$ ) Bchalen. De correlaties varieren van .40 tot .60 . De correlaties tusaen de beide externe-schalen en de interne-schaal zijn echter beduidend lager. Deze varieren van -.25 tot 19 (Levengon, 1973; Wallaton e.ra., 1976a; Walkey, 1979).

Samenvattend kunnen we zeggen dat de MLOC een betrouwbaar meetingtrument 1s, warblj een onderscheid is gemaakt in drie beheersende instanties, welke op een min of meer constante wijze met elkar samenhangen. Uit factor-analytische studies is niet gebleken dat er verschillende bekrachti-
gingagebieden an ten grondslag liggen. 
Vergelijken we belide algemene beheersingsorientatie-vragenlijaten, dan $11 j k t$ de MLOC in potentie ieen betere vragenlijst dan de LOC. In tegenstelling tot de $L O C$ wordt in de MLOC de beheersende instantle onderverdeeld naer drie instanties, terwijl de itens betrekking hebben op een berkrachtingsgebied, namelljk gebeurtenissen vit de directe omgeving. Dit is nlet alleen de betrouwbaarheid ten goede gekomen, maar hierdoor werd ook duidelijker wat met de betreffende schalen gemeten wordt.

Gebruiken we de MLOC als indicator van de beheersingoorientatie dan rest de Vraag wat de $L O C$ meet. Dit in verband met het feit dat het merendeel van de studies ontrent de beheersingsorientatie verricht zijn met de LOC. Uit correlatie-berekeningen met de MLOC blijkt dat de LOC positief correleert met de kans-schal van de MLOC (de samenhang varieert van .43 tot .56), en negatief met de interne-schaal (van -.15 tot -.41 ). De LoC hangt echter slechts in beperkte mate aamen met de machtige anderen-schael (van .22 tot .25), (Levenson, 1981). De machtige anderen-schaal blijkt zelfa bij een multiple-regressie-analyse in het geheel niet bij te dragen aan de verklaring van de LOC (Levenson, 1981). Met name de kang-gchabl bleek bij deze analyse de LOC te verklaren. Als multiple correlatie werd gevonden .43 , welke na toevoeging van de interne schaal steeg tot . 53 . Hieruit kunnen we afleiden dat een LOC-score voornamelijk indicatief is voor de kans-orientatie, dus voor de mate warin men verwacht dat gebeurtenissen worden beinvloed door kans of geluk.

\subsubsection{GEZONDHEIDSSPECIF IEKE BEHEERSINGSOR IENTATIE-SCHALEN}

Op dit moment zijn een tweetal gezondheidsspecifieke beheeraingsorientatie-schalen geconatrueerd. Beide zijn ontwikkeld door Wallatom e.a. (1976a, 1978a). De eerste 1ijst, de Health Locus of Control Scale (HLC) is, evenals Rotter's LOC, gebaseerd op een eén-dimensionaal conatruct. De tweede lijst, de Multi-dimengional Health Locus of Control Scale (MHLC), verschilt van de eerste door in navolging van Levenson meerdere beheeraende instanties te onderscheliden.

\subsubsection{DE HEALTH LOCUS OF CONTROL SCALE}

Deze $11 \mathrm{j} s t$ bevat 5 interne en 6 externe items, elk met een Likert-type antwoord-schaal. Voorbeelden van dergelijke items zijn: "Als ik goed voor mezelf zorg, kan ik zilekte voorkomen" (Intern item) en "Een goede gezondheid is woornamelijk een kwestie van weel geluk" (extern item). 
De eerste gegevens ontrent de interne betrouwbarheid bleken goed, name$11 \mathrm{jk} .72$ (Wallaton e.4., 1976a). Echter in latere atudies werden steeds lagere coefficlenten gevonden, varierend van .36 tot .54 (Wallston e.a., 1976a; Lew1s e.a., 1978; Boyle en Harrison, 1981). Test-hertest betrouwbartheld bleek. 71 te $2 i j n$ bij een tijdsinterval van 7 weken (Wallstion e.a., 1976a), hetgeen bevestigd werd door McCusker en Morrow (1979). Zij vonden bij een tijdsinterval van 4 weken een coefficlent van .69. Geen semenhang is gevonden met sociale wenselijkheid (Wallston e.8., 1976a; Lewlo e.a., 1978).

Uit de lage interne betrouwbarcheden is af te leiden dat we ook hier te maken hebben met een heterogene schaal. Factoranalyse leidde dan ook tot de conclusie dat de interne en de externe items twee afzonderilijke dimensies vormen (Boyle en Herrison, 1981; Meyers e.a., 1982). Wallston e*a. kregen zelf echter bok bedenkingen ten aanzien van de structuur van de achaal. Twee schalen die op basis van de HLC waren samengesteld uit respectievelijk de interne en de externe items bleken namelijk exact nul met elkan te correleren (Wallaton e.e., 1978a). Vandar dat zij een nieuwe Ljat conatrueerden naer analogle van de lijat van Levengon, namelijk de Multi-dimensional Health Locus of Control Scale (MHLC).

\subsubsection{DE MULTI-DIMENSIONAL HEALTH LOCUS OF CONTROL SCALE}

Alvorens op deze lijat in te gaen moet worden opgemerkt dat Wallston e.a. (1978a) twee lijsten, namelijk varm $A$ en vorm $B$, ontwikkeld hebben. Aangezien in de literatuur voornamelijk varm A gebruikt is, zullen we ons tot deze 11 jot beperken.

De lijjst bevat, in navolging van Levenson (1973) drie schalen, te weten cen interne-, een machtige anderen-, en een kans-schaal. Elke schaal beatabt uit 6 items, welke een Likert-type antwoord-achaal hebben. Voorbeelden van items zijin: "Het belangrijkste dat mijn gezondheid beinvloedt, is hetgeen ik zelf doe" (intern), "Wat betreft mijn gezondheid ken lk alleen maar doen wat mijn dokter mij zegt" (machtige anderen), "Hoe snel ik van een ziekte genees, wordt grotendeels door geluk bepaald" (kanis).

De interne consistentie van deze lijst is over het algemeen goed. Wallaton e.a. (1978a) vonden voor de interne orientatie (Internal Health Locus of Control; IHLC) een betrouwbaarheidscoefficient van . 77 , voor de machtige anderen-orientatie (Powerful athers Health Locus of Control; PHLC) .67 , en voor de kans-orientatie (Chance Health Locus of Control; CHLC) .75 , hetgeen overeenkomt met de bevindingen uit andere studies (zie Wallaton en Wallston, 1981). 0ok de test-hertest betrouwbaarheden blijken redelijk te $21 j n$, namelijk .66 (IHLC), .71 (PHLC) en .73 (CHLC) bij een tijdainterval van 4 tot 6 maanden (Wallston e.a., 1981). Ook de sanenthang met sociale wenselijkheid is, met uitzondering van de CHLC, laag, name- 
$11 \mathrm{Jk} .10$ (IHLC), .09 (PHLC) en -.24 (CHLC) (Wallaton en Wallstion, 1981). Factoranalyse op de totale 1ijst bevestigde de beoogde factoren (Hartike en Kunce, 1982). De onderlinge relaties varieren echter nogal van die van Levenson. De interne schaal blijkt enigszins samen te hangen met de belde externe orientaties, namelijk .12 (PHLC) en -.29 (CHLC), terwijl de onderlinge relatie tussen beide externe orientaties lager is den bij Levenson, namelijk slechts .20 (Wallaton e.a., 1978a). Hartke en Kunce (1982) vinden soortgelijke relaties, terwij1 Larde en Clopton (1983) een sterkere samenhang vinden tussen beide externe orientaties, namelijk .53, hetgeen meer overeenkomt met de bevindingen met Levenson' $: M L O C$.

De samenhangen met de overeenkomstige schalen van Levenson blijken respectlevelijk .57 (I), .28 (P), en .80 (C) te zijn. Hierult blijkt dat, met uitzondering van de PHLC, de overeenkonstige schalen soortgelijke concepten meten. De lagere correlatie bij de PHLC kan verklaard worden door het specifieke karakter van de bekrachtiging (gezondheid en zlekte) en de beheersende instantie (de arts). De arts neent bij de beheersing van gezondheid en ziekte een bijzondere positie in, welke minder sterk geldt voor machtige anderen bij algemene gebeurtenissen. Dit verklaert ook waarom de samenhang tussen de belde externe gezondheidsapecifieke orientaties minder sterk is dan bij de MLOC.

Samenvattend kunnen we zeggen dat van de gezondheidsspecifieke vrageniijsten feltelijk alleen de MHLC geschikt is an de beheersingsorientatie ten aanzien van gezondheid te meten. De HLC heeft dezelfde tekortkoning als Rotter"s LOC, aangezien de interne en de externe items onafhankelijk van elkaar zijn.

Opgemerkt moet worden det bij belde vragenlijsten geen afzonderlijke schalen geconstrueerd zijn voor de positieve en de negatieve bekrachtiging, zoals gezond worden of blijven en ziek worden. Hoewel beide vormen van bekrachtiging in de vragenlijgten verwerkt $z i j i n$, is in geen enkele studie een dergelijk onderscheid gevonden. Personen schatten de beheersing van gezondheid en ziekte dus op soortgelijke wijze in, zodat het niet noodzakelijk is aparte schalen hiervoor te construeren.

Aangezien geen gegevena bekend zijn over de relatie tussen de totaalacore van de $H L C$ en de MHLC, is het minder duidelijk hoe gegevens verkregen met de HLC, geinterpreteerd moeten worden. Wel is bekend dat de viff interne 1tems van de HLC sterk samenhangen met de IHLC (.70) en in mindere mate met de CHLC $(-.30)$ en de PHLC $(.22)$, terwijl de externe items van de HLC hoog correleren met de CHLC $(.79)$ en minder hoog met de IHLC $(-.30)$ en de PHLC (.15) (Wallaton e.a., 197Ba). Dit betekent dat de HLC zowel lets zegt over de interne orientatle (met name door de interne items) als over de kans-orientatie (met name door de externe items). Voor beide vornt de HLC echter een slechte indicator, aangezien de interne- en de kans-oriertatie slechts in beperkte mate met elkaar samenhangen, zodat een totalscore een grote mate van ruis bevat. 


\subsubsection{SAMENVATTING ENGELSTALIGE BEHEERS INGSORIENTITIE VRAGENLI JSTEN}

Een viertal vragenlijsten zijn tot nu toe besproken: twee algemene en twee specifieke beheersingsorientatie vragenlijsten. Van een tweetal vragenlijaten is de bruikbaarheid ter discussie gesteld, namelijk van Rotter" LOC en de HLC van Wallston e.a. Het belangrijkste bezwar van beide vragenlijaten is het feit dat deze gebaseerd zijn op een één-dimensionaal concept. Eerder hebben we al gezien dat uit diverge anderzoeken gebleken is Wat een interne en een externe beheersingsorlentatie twee of meer afzonderlijke orlentaties vormen. De betekenis van een sonscore over deze vergchillende orientaties is zodoende onduidelijk.

Andere bezwaren die met name van toepassing ziljn op de LOC, zijn het sterke vermoeden dat de externe items geen externe beheersingsorientatie meten maar machteloosheid, en het feit dat de LOC de beheersingsarientaties meet ten aanzien van twee geheel verschillende bekrachtigingsgebieden, namelijk politieke gebeurtenissen en gebeurtenissen uit de directe omgeving. De betrouwbaarheid van de LOC is ook laag voor een schael van 23 items.

De twee resterende vragenlijsten, de MLOC van Levenson en de MHLC van Wallston e.ब., bleken wel te voldoen aan de door ons gestelde criteria. In beide vragenlijsten worden meerdere beheersende instanties onderscheiden, waarvan voor elk een aparte schaal is geconstrueerd. Verder is in beide vragenlijsten een beperking aanwezig voor wat betreft de bekrachtigingagebieden. De MHLC beperkt zich uitsluitend tot gezondheid en ziekte, terwijl de MLOC, hoewel een algemene schaal, zich beperkt tot gebeurtenissen uit de directe ongeving.

Overigens betekent bovenstaande niet dat beide achalen zonder meer valide zijn. Wel dat ze in potentie voldoen om de beheersingsorientatie te meten. In het volgende hoofdstuk zal aandacht worden besteed aan de vraag in welke mate de betreffende wragenlijsten verklarende waarde hebben.

\subsection{NEDERLANDSTALIGE BEHEERSINGSDRIENTATIE VRAGENL IJSTEN}

In Nederland zijn tot nu toe verschillende beheersingsorientatie vrageniljoten vertaald of geconstrueerd. Behalve twee algemene wragenlijsten (Andriessen, 1972; Radenburg, 1974), zijn er ook enkele specifieke schalen geconstrueerd, zoals de LOCO, een lijst gericht op de opvoeding van kinderen (Leenders, 1983), de LOCH, een lijgt voor het meten van de beheersingsorientatie voor hulisartsen (De Jong, 1981), de MHLC, een vertaling van de Mill van Wallstan e.a. (Van Euring-Withaar e.a., vlgs. Jonkers e.a., 1981), en tot slot heeft Heling (1983) een eerste stap gezet on een nieuwe gezondheidsspecifieke schaal te construeren. 
Over het algemeen zijn over deze vragenlijsten nog weinig gegevens bekend. Een uitzondering hierop is de algemene vragenlij st van Andriessen (1972). Waarschijnlijk door het beschikbaar zijn van deze lijst is de belangatelling in Nederland voor de beheersingsorientatie in de jaxen 70 sterk gegroeid.

Verschillende verkorte versies zijn op basis van deze lijst sanengesteld. Zo kennen we een lijst bestaande uit 12 items, een 1 ijst bestaande uit 14 items (Andriessen, 1974), en sinds kort hebben Andriessen en Van Cadsand (1983) ook een lijst met 18 items geintroduceerd. Op welke wijze de 11 jst met 12 items tot stand is gekomen is onduidelijk. De gebruikers van deze $11 j s t$ (zie 0.a. Koppelaar en Vlaander, 1983) stellen dat de 12 items de hoogst ladende items uit de lange lijat zijn. Hiervoor verwijzen zij naar de publicatie van Andriessen (1972). In dit artikel troffen wij de betreffende ladingen echter niet aan.

De oorspronkelijke vragenlijgt van Andriessen is een vertalde en enigszins aangepaste versie van Rotter's LOC. De forced-choice items zijn echter vervangen door items met Likert-type antwoord-schalen en grafische antwoord-schalen. Aangezlen deze vragenlijst grotendeels een vertaling is van Rotter's LOC betekent dit dat deze dezelfde tekortkomingen heeft als de $L O C$, namelijk de verwevenheid met machteloosheid, het miet onderacheiden van interne en externe beheersende instanties en het niet onderscheiden van bekrachtigingagebieden.

Factor-analyse op deze lijat laat zien dat er twee onafhankelijke factoren zijjn, namelijk een factor met interne items en een met externe items (Van Cadsand, 1977; Andriessen en Van Cadsand, 1983). Andriessen en Van Cadsand zelf zijn echter niet overtuigd van de multi-dimenaionaliteit van de vragenlijst. Op grond van diverse samenhangen met andere persoonskenmerken komen de beide onderzoekers tot de conclusie dat het weinig zin heeft van de interne en van de externe items afzonderlijke schalen te meken, aangezien beide geen extra informatie geven boven de totaalscore. Hoewel deze conclusie tot op zekere hoogte juist is, lifket het ons van belang te weten welk deel van de beheersingsorlentatile verantwoordelijk is voor de samenhang. Uit de door hen gepregenteerde gegevens blijkt dat slechts in vier gevallen de samenhang met de interne en de externe beheersingsorientatie in overeenstemming is met de samenhang met de totalscore. In alle andere gevallen waar een samenhang ia met een per soonokenmerk, is slechts een van belde afzanderlijke schalen verantwoordelijk voor de samenhang. Verder blijken de persoonskenmerken in twee gevallen op dezelfide wijze samen te hangen met zowel de interne als de externe schaal, in tegenstelling tot de verwachting dat de persoonskenmerken een samenhang vertonen met de interne scharl die tegengesteld is aan de samenhang met de externe achaal. Zo is er zowel bij de interne als bij de externe schaal een negatieve samenhang met het aantal gezondheidsklachtien (VOEG) en met de mate warin men prestatiegericht is. Recent kont Gall (1985) na een her-analyse van de gegevens van Andrlessen en Van Cadsand ook tot de concluaie dat de interne en de externe items opgevat noeten worden als verschillende concepten. 
Op grond van deze gegevene nemen we an dat de door Andriessen geconstrucerde vragenlijst mult-dimensional van aard is. De interne en de externe item blijken onafhankelijke fectoren te vormen, terwijl de interne en de externe items grotendeels met verschillende persoonskenmerken samenhangen. Deze multi-dimensionaliteit vinden we ook terug in de verkorte vragenlijat met 14 items. Van de andere verkorte versies $z 1 j n$ geen aparte factor-analyses bekend. Wiersma (1979) heeft als enige de lijst met 14 items (Andriessen, 1974), na factoranalyse, in het geheel gebruikt. Twee van de vier interne items bleken echter een lage lading op de eerste factor te hebben. Bij Andriesien (1974) vormden na factor-analyse slechts 10 items een schaal. Deze schaal bevatte 9 externe items en slechts 1 intern item. Een goortgelijke verhouding kreeg Ormel (1980). Hij paste de wragenlijat met 14 items eniggzins aan, en moest na factor-analyge twee interne items verwijderen, zodat hij uiteindelijk een $\mathbb{1 i j}$ st met 10 externe en 2 interne items overhield. In beide gevellen is dus na factormalyse een achal overgebleven met vrijwel alleen externe items. Ook hier zien we dus dat er een onderscheid gemakkt wordt tussen de interne en de externe itema, met dit verachil dat door hun geringe aantal, de interne items buiten de uiteindelijke schaal vallen.

In een door ons verricht onder zoek in 1981 (zie hoofdstuk 6) wordt dit bevestigd. Naast andere vragen zijn toen de resterende 12 items uit het onderzoek van Ormel gan de reapondenten vaorgelegd, echter nadat deze ofwisgelend intern en extern geformuleerd waren. Factoranalyse op deze gegevens bevestigde dat de interne en de externe items twee anafhankelijke factoren vormen (zie bijlage 2 ). De samenhang tussen belde schalen bedroeg .02 .

Uit het voorgaende wordt duidelijk dat ook de Nederlandse versies van Rotter"s beheersingoorientatie-schaal feitelijk een multi-dimensionaal concept meten, hetgeen op basis van het voorgaande hoofdstuk ook verwacht mockt worden. Wellicht dat dit ook ten dele de vaak teleuratellende regultaten van onderzoek met de beheersingsorientatie verklaart.

Een Nederlandse 11jst warin wel een duidelijk onderscheid gemaakt is in de beheersende inatantles, is een vertaling van de MHLC van Wallston e.a. (Van Burink-Withaar e.a., vlgs. Jonkers e.a., 1981). Op deze lijst zullen we in hoofdatuk 7 verder ingean.

\subsection{SAMENVATTING}

In dit hoofdstuk is aandacht besteed aan de meting van de beheersingsorientatle. Enkelle keuzemomenten en criteria, wasmee rekening moet worden gehouden bij het meten van de beheersingsorientatie, zijn geformuleerd. Zo moeten de interne en de externe beheersende instanties onderscheiden worden, terwijl ook de beheersingsorientaties over verschillende 
bekrachtigingegebieden niet zonder meer gesommeerd mogen worden. Verder kan het in bepaalde gevallen zinvol zijn een onderscheld te maken in positieve en negatieve bekrachtigingen.

Een aantal meetinstrumenten zijn an de hand van, onder andere, deze keuzemomenten en criteria besproken. Op basis hiervan is gesteld dat de oorspronkelijke LOC van Rotter, en een gezondheidaspecifieke vragenlijat (de HLC) minder bruikbare meetinstrumenten zijn dan de vragenlijst van Levenson (MLOC) en de gezondheidaspecifieke vragenlijst van Wallston e.a. (MHLC). Aangezlien de meeste in Nederland gebruikte vragenlijsten afgeleide versies zijn van de $L O C$ van Rotter, worden deze on dezelfde reden als bilj de LOC, minder bruikbaar geacht. 
Vanwege het enorme aanbod aan literatuur op het gebied van de beheersingsorientatie beperken we ons in dit hoofdatuk tot de literatuur die betrekking heeft op de relatie tussen beheersingsorientatie en gezondheids en zlektegedrag. Dit betekent ook dat vrijwel geen literatuur is opgenomen over aanverwante concepten, zoels machteloosheid. Voor informatie ontrent de relatie tuagen beheersingsorientatie en andere gedragingen zoals interpersoonlijk gedrag, cognitieve activiteiten, prestatlegerichtheid en politieke activiteiten, verwijzen we de lezer naar andere overzichtawerken, zoalg Joe (1971), Lefcourt (1976, 1981b), Phares (1976), Strickland (1978), en Klandermans (1983).

Alvorens de literatuur te bespreken warin de beheersingsorientatie is gebruikt als onefhankelijke wariabele om gezondheids- en ziektegedrag te verklaren, zal eerat ingegaan worden op de vraag in hoeverre de beheersingsorientatie samenhangt met enkele demagrafiache variabelen en met de gezondheidetoestand.

\section{I DEMOGRAF ISCHE VARIABELEN EN GEZONDHEIDSTOESTAND}

\subsubsection{DEMOGRAF ISCHE VARIABELEN}

Van een drietal demografísche wariabelen zijn gegevens bekend, namelijk van sexe, leeftijd en sociaal-economische status.

Van deze variabelen blijkt sexe niet of nouwelijks met de diverse beheeralngsorientatie-vragenlijaten samen te hangen (Phares, 1976; Levenson, 1981; Wallaton en Wallaton, 1981). In die gevallen warr wel een, zij het geringe, samenheng gevonden werd, bleek dat mannen over het algemeen meer intern- machtige anderen-georienteerd zijin dan vrouwen (Walkey, 1979). Wellicht dat mannen iets meer dan vrouwen van mening zijn dat gebeurtenissen beheerst kunnen worden. Wel zijn er aanwijzingen dat sexe van belang is bij de ontwikkeling van de beheersingsorientatie. Zo schijnen vrouwen tijdens hun jeugd een meer interne orientatie te ontwikkelen in een afwijzende thuis-aituatie, terwijl mannen juist in een helpende en beschermende thuis-situatie een interne orlentatie ontwikkelen (Levenson, 1981). Hierover zijn met betrekking tot de gezondheidsspecifieke beheersingsorientatie geen gegevens bekend. 
Een probleem dat met name bij de gezondheidsspecifieke vragenlijsten een rol apeelt is het felt dat deze vragenlijsten voornamelijk gebrulkt zijn bij kleine steekproeven uit specifieke populaties, vooral studentenpopulaties. Hierdoor zijn vaak geen uitspraken over demografiache kenmerken te doen, of zijn de uitspraken tegenstrijdig. Met name doet dit probleem zich voor blj leeftijd en sociaal-economische status.

Er is dan ook wat betreft de gezondheidsspecifieke lijsten nog weinig bekend over de relatie beheersingsorientatie en leeftijd. Slechts in ến atudie (Wallston en Wallation, 1981) werd een geringe relatile gevonden tussen leeftijd en de arts-orientatie. Met de schaal van Rotter vertioont leeftijjd geen samenhang (Rotter, 1966; Van Cadsand, 1977) en over de relatiea met de schalen van Levenson zijn in deze geen gegevens bekend.

Over de invloed van sociaal-economische status op de gezondheldsspecieke vragenlijaten zijn de resultaten ook niet eenduidig. Toch zijn er enige aanwijzingen dat personen met aen lagere sociaal-economische atatus meer extern-georienteerd zijn (Wallaton en Wallaton, 1981). Bij de beide algemene vragenlijsten komt dit duidelijker naar voren. Personen uit de lagere milieus blijken meer extern georienteerd te zijn (Rotter, 1966; Levenson, 1981).

Samenvattend kunnen we zeggen dat sexe waargchijnlijk niet of nauwelijks gerelateerd is aan de (gezandheidsspecifieke) beheersingsorientatie. Voor leeftijd is dit nog onduidelijk, terwijl sociaal-economlsche status wel gerelateerd is aan de algemene beheersingsorientatie, en vermoedelljk ook an de gezondheidsspecifieke beheersingsorientatile.

\subsubsection{GEZONDHEIDSTOESTAND}

Uit theoretische overwegingen mag men veronderstellen dat de mate warin men zich gezond voelt en/of de mate warin men ervaring heeft met gezondheldezorgvoorzieningen van invloed ls op de beheersingsorlentatie ten aanzien van gezondheid en zlekte. Zo blijken peroonen met een beparalde ziekte een minder uitgesproken of een meer genuanceerde opvatting te hebben over de oorzaak van de ziekte dan personen zonder dle zlekte (Linn e.s., 1982). Verder blijjkt uit verschlllende atudies (Andersen, 1979; Baughman, 1978; Seeman en Seemen, 1983; Walliston e.a., 1978a; Walloton en Wallaton, 1981) dat personen met een slechte gezondheld of chronische aandoening een relatief lagere interne en een relatief hogere externe (zowel kans- als arts-) orientetie hebben. Zij blijken echter ook minder zelf-controlie te wensen (Mullins, 1982).

De vraag is of een meer externe verwachting slechts een tijdelijke of een blijvende aampassing is voor degenen met een slechte gezondheid. Sinth en Carson (1981) laat zien dat degenen die langer gebrulk maken van een dialyse-apparaat een hogere interne beheersingsorientatie hebben $(r=92)$. Deze, overigens wel uitzonderlijk hoge, samenhang zou erop kunnen wijzen 
dat men zich bij een chronlache aendoening allereerst afhankelijik voelt van de gezondheldazorg, terwijl men in tweede instantie weer mogelijkheden ziet on zelf de gezondheid te beinvloeden. Het anderzoek van smith en Carson (1981) last het echter niet toe om van eventuele verschuivingen te apreken, aangezien het een eenmalige meting betreft. Voor terminale patienten 18 ook een andere verklaring magelijk, namelijk dat juist degenen met een langere Levensduur een minder externe orientatie hebben. Zo meldt Levenson (1981) dat Achterberg e.a. in een onderzoek bij kenkerpatienten vonden dat de machtige anderen-orientatie een voorapellende warde had ten aanzien van het toekomstige ziekteverloop. Degenen met een langere Levensdutur den op grond van medische gegevens voorspeld was, bleken een lagere PLOC te hebben dan degenen wiens levensduur wel overeenkwam met de voorspelde duur.

Met de LOC wan Rotter werd overigens geen relatie gevonden tussen de beheeraingsorientatie en de gezondheidstoestand (Kivett e.a., 1977).

Samenvattend kunnen we zeggen dat de gezondheidstoestand samenhangt mat de gezondheidsepecifieke beheersingsorientatie. Degenen die hun gezondheid als slecht beoordelen zijn over het algemeen meer extern-georienteerd.

\subsection{GEZONDHEIDS- EN ZIEKTEGEDRAG}

\subsubsection{INLEIOING}

Diverse onderzoeken zijn verricht neer de relatie tussen gezondheids- en ziektegedrag en beheersingsorientatie. Met name naar de relatie met rookgewoontes, avergewicht, overmatig alcoholgebruik, borst-zelfonderzoek en informatle inwinnen. De relatie met andere gezondhelds- en ziektegedragingen, zoals 1ichaamabeweging, matig alcoholgebruik, doktersbezoek, en medicijngebrulk, zijn tot nu toe vrijwel niet onderzocht.

Alvorens op deze relaties in te gaan volgen nu nog een tweetal algemene opmerkingen. De verrichte onderzoeken zijn vaak uitgevoerd bij kleine specifieke groepen. Generallisatie is dan meestal niet, of slechts beperkt mogelijk, terwijl de reaultaten vaak tegenstrijdig zijn. In de onderzoeken wordt ook naumelijks rekening gehouden met eventuele intervenierende factoren zoals sexe, leeftijd, socieal-economische status of gezondheidstoestand.

Verder is in hoofdstuk 3 al kort angegeven dat de beheersingsorientatie slechts onder bepaalde condities van invloed is op gedrag. Wordt de beheersingoorientatie gebruikt als onafhankelijke variabele dan moet rekening worden gehouden met de warde die het individu aan de bekrachtiging hecht en moet de situatie min of meer nieuw of ambigue zijn. Ten aanzien van de laatate conditie kan worden opgemerkt dat deze minder relevant 
wordt naarmate de beheersingsorientatie specifleker gemeten wordt. De gegeneraliseerde verwachting benadert dan namelijk steedo meer de speclfieke verwachting omtrent de beheersing. Mocht er sprake zljn van een situatie die niet nieuw of ambigue is den mag worden aangenomen dat de specifieke werwachting ontrent de beheersing grotendeels gebaseerd is op vroegere aituaties en dus congruent is met de huidige situatie. Wat betreft de waarde die men hecht aan de eigen gezondheid is thet nog niet duidelijk of deze relevant is of niet. In een aantal onderzoeken heeft een onderscheid in personen die wel en die niet weel waarde thechten aan de gezondheid, geleld tot significante relaties tussen beheersingsorientatle en ziekte en/of gezondheidsgedrag (0.a. Seeman en Seeman, 1983; Saltzer, 1978; Kaplan en Cowles, 1978), terwij1 in ander onderzoek (Baughman, 1978) geen relatie gevonden werd.

Vaak wordt echter in onderzoek geen aandacht geachonken aan de genoemde condities. In die gevallen warin het voor het betoog relevant is zal worden aangegeven of is voldaan aan deze conditiea.

\subsubsection{ROKEN}

De bevindingen ontrent de relatie beheersingsorientatie en roken zijn niet eendulidig. Sommigen vinden dat rokers lets meer extern-georienteerd zijn (Clarke e.a., 1982; Seeman en Seeman, 1983; Stralts en Sechrest, 1963), terwij, anderen geen verschil in deze vinden tussen rokers, ex-rokers en nooit rokers (McCuster en Morrow, 1979, Mlott en Mlott, 1975). Dok de relatie met het aantal sigaretten dat men rookt is onduidelijk. Volgens Clarke e.a. (1982) is het aantal sigaretten positief gerelateerd aan een externe beheersingaorientatie, terwijl Baughman (1978) juilat vindt dat het aantal sigaretten negatief gerelateerd 1 a an de PHLC. Baughman (1978) is overigens de enige die in dit kader gebruik makt van de MHLC.

Wellicht dat deze tegenstrijdige resultaten verklaard kuninen warden doordat er geen direct, maer een indirect verband bestaat tussen rookgewoontes en beheersingsorientatie. Zo vinden Seemain en Seeman (1983) dat de reliatie tussen roken en een externe orientatie alleen significant is voor degenen die van mening zijn dat roken slechts enigszins samenhangt met kanker. Voor degenen die dit risico groter achten, werd geen relatie gevonden tussen de beheersingorientatie en roken. Verder wonden McCusker en Morrow (1979) dat met name intern-georienteerden de kani groter achtten dat ze kanker krijgen. Dit woog echter weer op tegen hun grotere vertrouwen in screeningstesten, zodat ze uiteindelijk minder bang bleken te zijn on kanker te krijgen dan extern-georienteerden. Zodoende vonden Mccusker en Morrow (1979) geen verschil tussen rokers, ex-rokers en noolt rokers. voor wat de beheersingaorientatie betreft. 
Coan (1973b) maakte een onderscheid in aangepsate rokers (welke plezier en ontspanniling ervaren) en niet-aangepaste rokers (welke spanning en verslavingssymptomen ervaren). Uit zijn onderzoek bleken de aangepaste rokers zlch ondermeer te onderschelden van de nilet-aangepaste rokers door een sterker ervaren controle.

Op basis van het voorgaende kunnen we stellien dat er warschijnlijk geen of anders alechts een geringe directe relatie is tussen enerzijds de beheersingaorientatie en anderzijds het al of niet roken en het aantal sigaretten dat gerookt wordt. Wel zijn er aenwijzingen dat de beheersingsorientatie gerelateerd 19 aan raokgedrag, mear op een complexere wijze. Ook bij interventie-programma's blijkt er meestal geen directe relatie te bestaen tussen de beheeraingsorientatie en het effect van deze programma's (Danaher, 1977). Wel blijkt dat intern-georienteerden meer baat hebben bij programa's, welke gebaseerd zijn op meer intern-georienteerde procedures, bijwoorbeeld "stimulus satiation aversion procedures", terwil extern-georienteerden meer bast hebben bij programma"s welke het rookgedrag relateren aan situationele of externe factoren (Best, 1975; Best en Steffy, 1975; Chamb11ss en Murray, 1979a; Kaplan en Cowles, 1978; Shipley, 1981). Dit effect kont nog duidelijker naer voren naarmate de interventie langer geleden is (Best, 1975; Best en Steffy, 1975; Shipley, 1981). Verder blijkt uit een onderzoek van Kaplan en Cowles (1978) dat met name intern-georienteerden die veel waarde hechten aan de gezondheid, na een interventie-programma stoppen.

Samenvattend kunnen we zeggen dat er warschijnlijk geen direct verband bestast tussen de beheeraingsorlentatie en rookgewoontes of het stoppen met roken. Hel blijken interm-georienteerden andere opvattingen te hebben over de gevolgen van roken, en moeten ze op een andere wijze gemotiveerd worden om te stoppen met roken.

\subsubsection{ALCOHOLCONSUMPTIE}

Verschlllende studies zijin verricht naar de relatie tusaen beheersingsorientatie en alcoholgebruik. Vaak is geprobeerd an de hand van de beheeralingsorientatie een onderscheid te maken tussen alcoholisten en nietalcohaliaten. De resultaten hiervan zijn tegenstrijdig. Sommige vinden dat alcohollsten meer extern-georienteerd zijn, anderen vinden dat alcohollsten meer intern-georienteerd $z i j n$, terwijl weer anderen geen versch11len vinden (Boyle en Silelski, 1981; Butts en Chotlos, 1973; Donovan en 04Leary, 1975; Levenson, 1981).

Theoretiach zou men veronderstellen dat alcohollsten meer extern georienteerd zijn, daar zij vaak niet over adequate vaardigheden beschikken om hun leven te beheersen. Het is echter niet uitgesloten dat alcoholisten van mening zijn dat zij juist door hun alcoholgebruik greep hebben op hun (gevoels) leven. Dit zou betekenen dat de gebrulkelijke beheersingsorien- 
tetie-schalen niet geschikt zijn woor deze specifleke populatie (Worell en Tumilty, 1981). Voor dit laatste pleit een onderroek van Donovan en 0'Leary (1978). Zilj vonden met een zelf ontwikkelde alcahol-specifieke beheeraingsorientatie-schaal dat deze wel en Rotter's LOC niet differentieerde tussen alcoholisten en niet-alcoholisten. Ook de MLOC van Levenson lijkt voor een onderscheid tussen beide groepen relevant te $21 j \mathrm{n}$. Levenson (1981) noemt namelijk enkele studies waruit blijkt dat leoholisten wel hoger scoren op de kans-schaal, maar geen significante verschillen met de niet-alcoholisten vertonen op de interne schaal. Aangezien de door Donovan en D'Leary (1978) ontwikkelde schaal met name met Levenson's kans-schaal samenhangt, kunnen we concluderen dat alcohollsten en nietalcoholisten warschijnlijk verschillen ten aanzien van thun kang-orientatie (Levenson, 1981).

Bij andere populaties dan alcoholisten lijkt er ook een relatie te bestaan tussen een externe orientatie en alcoholgebruik (Naditch, 1975; Baughnan, 1978). Het onderzoek van Baughman (1978) wijst erop dat van de externe-orientatie met name de kens-orientatie relevant 19 .

Apeo en Damon (1982) maakten in hun onderzoek onderscheid tussen de frequentie in drinken en de hoeveelheld glazen per keer. Het bleek dat een externe-orientatie wel samenhing met de frequentie, maer niet met de hoeveelheid. Aangezien zij gebruik maakten van Rotter's LOC omdat die vooral samenhangt met de kans-orientatie, mag worden aangenomen worden dat de relatie vooral betrekking heeft op de kans-orlentatie. Op basis van deze resultaten suggereren Apao en Damon dat de frequentie wellicht meer persoonsgebanden is, terwijl de hoeveelheid meer situationeel bepaald is. Hoe vaak men per maand alcohol drinkt bepaalt men zelf, de hoeveelheid wordt echter meer door de omgeving bepaald.

Weinig is tot nu toe bekend over de rol van de beheersingsorientatie bij interventle-programa's. Wel blijkt dat degenen die al in een vroeg stadium uitvalien een grotere kano-orientatie hebben (Walker e.a., 1980; Levenson, 1981).

Samenvattend kunnen we zeggen dat vooral de kans-orientatile gerelateerd is an lcoholgebruik en misbruik, Degenen die vaker alcohol drinken hebben een hogere kans-orientatie. De hoeveeliheid alcohol die men per gelegenheld drinkt, lijkt niet samen te hangen met de beheersingaorientatie. Wellicht dat dit meer door situatianele kenmerken bepald wordt.

\subsubsection{LICHAAMSBEWEGING}

Slechts twee studies zijn ons bekend over de relatie met licheamabeweging. Uit een onderzoek van Baughman (1978) kont naar voren dat degenen die en veel belang hechten aan hun gezonidheld én hoog scoorden op de PHLC, weinig aan lichaamsbeweging doen. Verder vonden Dishman e*A. (1980) dat degenen die langer participeerden aan een bewegings-programma minder extern-georienteerd waren (geneten met de HLC). 
Beide onderzoeken wijzen in de richting dat extern-georienteerden minder ean 1lchamabeweging doen. Daar we eerder hebben gezien dat extern-georienteerden over het algemeen een iets slechtere gezondheidstoestand hebben, lo het niet onaannemelljk det het gevonden verbend ten dele veroorzaakt wordt door het peit dat degenen met een slechtere gezondheid minder mogel1jkheden hebben on can licheamsbeweging te doen.

\subsubsection{GEW ICHTSAF NAME}

Verschllende gtudies zijn vericht naar de relatie met gewichtsafname bij interventie-programma's. In sommige studies werd geen relatie gevonden tuasen beheersingsorientatie en gewichtsafnane (Gierszewski, 1983; Kaplan, Wlgs. Wallston en Wallston, 1981; Saltzer, 1978; 1982), in andere studies daarentegen wel. Zo is gevonden dat intern-georienteerden wel een gewichtsafname berelken bij een op interne factoren gebaseerd programma, terw1j 1 extern-georienteerden een gewichtafiname vertonen bij een op externe factoren gebaseerd programa (Balch en Ross, 1975; Chambliss en Murrey, 1979b). Wallaton e.a. (1976a) konden deze relatie in hun onderzoek nilet beveatigen mear vonden wel, dat intern-georienteerden meer tevreden waren met een programma warbij ze een grote mate van vrijheid hadden, terwiljl extern-georienteerden meer tevreden waren met een door de therapeut bepaald programa.

Uit deze bevindingen is of te leiden dat intern-georienteerden hun witeindelijke gedrag bepalen aan de hand van andere factoren dan extern-georienteerden. In deze lijn past de bevinding van Saltzer (1978) dat intern-georienteerden hun intentile tot deelname aan een interventie-programma voornamelijk baseerden op hun eigen attitude, terwijl extern-georienteerden hun intentie voornamelijk bageerden op de mening van anderen. De intentie bleek echter alleen bij de intern-georienteerden samen te thangen met de feltelijke gewichtarfname $(r=.56)$.

Dat in ammige gevallen geen relatie gevonden is tussen gewichtsafname en beheersingsorientatie kan verschlllende oorzaken hebben. Zo stellen Wallaton en Wallaton (1981) dat gewichtsafname feitelijk geen gedrag is maar een gevolg en de beheersingsorientatie voorspell theoretlsch gezien geen gevolgen masir gedragingen. Een andere mogelijkheid is dat de beheersingsorlentatie niet apecifiek genoeg geneten 1s. Saltzer (1982) stelt in dit kader voor meer specifieke vragenlijaten te gebruiken, aangezien uit haar onderzoek bleek dat een specifiek op gewichtsafname gebaseerde vragenMJst wel de intentie voorspelde, maar dat Rotter's LOC of de MHLC dit nlet deden. Verder ken de tijdsfactor een rol spelen bij het al of niet vinden van verschillen tusien intern- en extern-georienteerden. Zo vond Kincey (1981) dat beide groepen na twee weken niet verschilden, maar dat na acht weken de intern-georienteerden een hogere gewichtsafname hadden bereikt den extern-georienteerden. 
Samenvattend kunnen we zeggen dat er aanwijzingen zijn dat de intern-georienteerden meer bat hebben bij een intern georlienteerd programma, terwijl het ongekeerde geld voor extern-georienteerden.

\subsubsection{INFORMATIE INWINNEN}

De hoeveelheid informatie die men heeft of inwint is vaak als criterium gebruikt bij validatie-atudies van de beheersingsorientatie-schalen. Een veel geciteerde studie in dit kader Is van Seeman en Evans (1962). Zij vonden, met een vragenlijst die later grotendeels is opgenomen in Rotter's LOC, dat tuberculose-patienten met een interne orientatie beter op de hoogte waren van hun toestand en meer vragen stelden aan artgen en verpleegkundigen. Lowery en Ducette (vlgs. Van den Boogaard en Boomsma (1981) vonden dat intern georienteerde diabeten beter geinformeerd waren over hun ziekte dan extern georienteerde diabeten. Dit gold echter alleen voor de eerste zes jaar dat ze diabetes hadden. Daarna was er nauwelljks nog verschil. Ook Ven den Boogaard en Boomma (1981) vanden dat interngeorlenteerden meer kennis hadden over diabetes den extern-georienteerden. Levenson (1972 vlgs. Levenson, 1981) vond bij milieu-activisten dat vooral kans-georienteerden minder informatle hadden over luchtverontreiniging dan degenen die niet van mening waren dat kans of geluk hun leven bepaalde. Geen relatie was er echter met de interne- en de machtige anderen-orientatie.

Sproles (vlgs. Wallaton en Wallston, 1981) vond met de HLC dat niler-dia1 yse patienten met een interne orientatie meer wisten en meer wilden weten over hun toestand, den patienten met een externe orientatie. Clum e.a. (1979) vonden echter geen bevestiging voor een dergelijke relatie bij patienten die een cholecystectomie moesten ondergaen. Wel vonden clum e.a. (1979) dat intern-georienteerden met veel informatie, in tegenatelling tot extern-georienteerden met veel informatie, vaker pijngtillende middelen gebruikten na de operatie. Aangezien er een positieve relatie beatond tussen hoeveelheid informatie en mate van pijn na de operatie, zou dit erop kunnen wijzen dat meer informatie leidt tot een hogere pijngevoeligheid, welke intern-georienteerden in tegengtelling tot extern-georienteerden probeerden op te lossen met behulp van geneesiniddelen. Tot slot vond Dunn (1980) bij gebruik van de MHLC bif scholleren dat met name de CHLC-achael negatief samenhengt met de mediache kennis ontrent zelf zorg. Dus kans-georienteerden hebben minder kennis omtrent zelfzorg. Hoewel Visser (1984) een soortgelijk verband vand bij ziekenhuispatienten, bleek dit geheel te verdwijnen indien rekening gehouden werd met aociaalculturele en sociaal-economioche kenmerken van de patienten. over het lgemeen wijzen de studies dus in de richting van een relatie tussen de beheersingsorientatie en de hoeveelheid informatle en/of kennis die men heeft. Bij de een-dimensionale schalen is er een negatieve rela- 
the tussen de externe opvatting en de hoveelheid informatie, terwijl uit de multi-dimensionale vragenlijsten blijkt dat met name de kans-orientatie negatief samenhangt met de hoeveelheid infomatie. Dit betekent dat met name degenen die gebeurtenissen toegchíjven aan kans of geluk over weinig informatie beschikken. Zowel de studie van Lowery en Ducette (v1ga. Van den Boogaard en Boomama, 1981) als de studie van Visser (1984) geven an dat deze conclusie genuanceerd moet worden. Uit de studie van Lowery en Ducette blijkt dat er vooral in het begin van de ziekte een verschil is tussen intern- en extern-georienteerden, termijl uit de studie van Visser (1984) is af te leiden dat de gevonden werschillen wellicht meer verklaard moeten worden door sociaal-culturele werschillen dan door een verachil in beheergingaorientatie. Verder kan opgemerkt worden dat het vooral bij de gezondheidsspecifieke beheersingsorientatie niet uitgesloten is dat mensen zich juiat meer extern-georienteerd waelen omdet ze geen of weinig informatie hebben.

Behalve de relatie met de hoeveelheid informatie la ook de relatie met het inwinnen van informatie onderzocht. Ter validering van de HLC vonden Wallaton e. grotere behoefte hadden on folders op te vragen ontrent hypertensie dan extern-georienteerden. In latere studies werd deze relatie steeds bevestigd, Indien het over hypertensie ging (Wallston en Wallston, 1981; DeVito e.a., 1982). Echter in een soortgelijk onderzoek naar overgewicht, werd deze relatie niet gevonden (Wallston en Wallston, 1981). Verder bleek uit een onderzoek van DeVito e.a. (1982) dat deze relatie bij hypertensie alleen opgat als het on de intentie tot het opvragen van folders gaat, zoals in het onderzoek van Wallston en wallston, maer niet als het on het feltelijke gedrag gaat.

Bij het tot stand komen van de MHLC wilden Wallston e.a. nogmaals de relatie tusaen de beheersingsorientatie en het inwinnen van informatie bestuderen. Op dezelfoe wijze als in 1976 met de HLC, en met soortgelijke respondenten (studenten), werd het onderzoek nu met de MHLC uítgevoerd. Opvallend was dat de beheersingaorientatie niet bleek samen te hangen met het Inwinnen van informatie. Aangiezien de auteurs vermoedden dat de houding ten aanzien van hypertensie in de loop der jeren veranderd was, vroegen ze in een volgend, identlek, onderzoelk behalve naar folders over hypertenaie, ook naar folders over herpes. Tot hun verbazing werd in dit enderzoek geen rellatie gevonden met het inwinnen van informatie over herpes, maar wel weer met het inwinnen van informatie over hypertensie. Personen die gezondheld belangriljk vonden en sterk arts-georienteerd waren, evenols degenen die gezondheid belangrijk vonden en iniet-kans-georienteerd waren, hadden een hogere intentie om folders ontrent hypertensie op te vragen dan de andere personen (Wallston en Wallston, 1981). Waarom in het ene onderzoek geen en in het ander onderzoek wel een verband werd gevonden met het inwinnen van informatie over hypertensie, is onduidelijk. Dok Wallstion en Wallston hebben hier geen afdoende verklaring voor. In een ander onderzoek bij personen met epilepsie, werd de door Wailstion en 
Wallston gevonden relatie tussen de PHLC en de intentie tot het inwinnen van informatile door mildel van folders wel bevestigd. Degenen die hoog scoorden op de PHLC bleken meer informatle te wilen inwinmen (DeVellis e.a., vlgs. Wellston en Wallston, 1981).

Een andere operationalisering van het inwinnen van informatie is het antal vragen dat men atelt aan de arts of verpleeglkundigen. Uit het reeds eerder genoemde onderzoek van Seeman en Evana (1962) bleek dat intern-georienteerden meer vragen stellen. Hetzelfde vond Sproles (vlgs. Wallston en Wallston, 1981) met de HLC bij nier-dialyse patienten. Krantz e.a. (1980) dearentegen vonden dat juist degenen met extreme acores, zowel intern als extern, meer vragen stelden dan degenen met gemididelde scores. Wallaton en Wallston (1981) vonden bij gebruik van de MHLC echter geen enkele relatie met het stellen van vragen door patienten bif de tandarts. Samenvattend kunnen we concluderen dat extern-georienteerden over minder informatie beschikken, warblj opgemerkt moet morden dat ar anwijzingen zijn dat een verschil in sociaal-culturele kennerken hiervan de oorzaak 18. De relatie met het inwinnen van informatie is onduidelijk. Soms werd een positieve relatie gevonden met een interne orientatie, soms met een machtige anderen orientatie, terwijl in andere gevallen geen relatie gevonden werd. Toch suggereert het felt dat extern- of kans-georlenteerden minder informatie hebben, dat zij ook minder informatie inwinnen. Het is echter niet uitgesioten dat extern-georienteerden aangeboden informatie minder lang vast houden of minder goed verwerken.

\subsubsection{COMPLIANCE-GEDRAG}

Verachillende studies zijn verricht naar compliance gedrag. De resultaten zijn echter tegenatrijdig. Zo noemen Wallston en Wallston (1981) zowel studies warult blijkt dat intern-georienteerden meer compliance gedrag vertonen, als studies waruit zou blijken dat extern-georienteerden meer compliance gedrag vertonen. Lewis e.a. (1978) wonden dat hypertensie-patienten welke intern-georienteerd zijn en thuis voldoende steun krijgen, meer compllance gedrag vertonen ten anzien van mediciJngebruik. Battle e.ai. (1982) darentegen vanden bij psychiatriache patienten dat juiat degenen met een externe orientatie en een hoge waardering van de gezondheld zich het best houden aam afopraken. Dit geldt echter alleen tot een maand na het ontslag. Dearne neent het verschil weer af. Battle e.a. (1982) vonden echter geen relatie met het zich houden aen de vourgeachreven medicijinen.

\subsubsection{PREVENTIEVE ACTIVITEITEN}

Diverae studies zijn werricht naar de relatie met preventieve activiteiten. Rosenblum e.a. (1981) vonden geen relatie tussen de beheersings. 
orientatie (MHLC) en het gedrag van moeders ontrent het aanbevolen inenten van hun kinderen. Dabbs en Kirscht (1971) makten een onderscheid tussen de verwachting dat men zelf controle heeft en de motivatie on zelf controle te hebben. Studenten met een lage verwachting of een hoge motivatie bleken meer een anti-griep spuit geheald te hebben dan de andere studenten. Aangezilen het krijgen van griep op verachillende wijzen kan worden vookkomen, kan dit exop dulden dat studenten met een hoge verwachting, dus met een interne orlentatie, meer van mening zijn dat ze op andere wijzen het krijgen wan de griep kurnen beheersen.

Dok ten aanzien van andere ziektes is het nemen van preventieve maatregelen onderzocht. Zo wonden McCusker en Morrow (1979) bij huisvrouwen geen relatie tubsen enerzijds de beheersingsorientatie en anderzijds het regelmatig verrichten ven borst-zelfonderzoek en jaarlijkse controles bij de dokter. Ook Seeman en Seemen (1983) en Jonkers e... (1982) vonden geen relatic tusgen borst-zelfonderzoek en de beheersingsorientatie. Valgens de theorie mag men echter pas een relatie verwachten als de bekrachtiging, dus in dit geval de gezondheid, belangrijk gevonden wordt. In overeenstemming hilermee ia de relatie die Seeman en Seeman (1983) wel vonden, namellijk dat intern-georienteerden die de gezondheid belangrijk vinden, meer aan boratzelfonderzoek doen dan intern-georienteerden die de gezondheid minder belangrijk vinden. Bij personen welke gonorroe hebben gehad, werd geen relatie tusaen de beheersingsorientatie en het nemen van toekomstige preventleve maatregelen gevonden (0lbrisch, vlgs. Wallaton en Wallation, 1981). Onbekend is of in deze studie rekening is gehouden met de warde die men an de gezondheid hecht.

Duidelijk is dat specifieke preventieve maatregelen warschijnlijk niet direct gerelateerd zijn aan de beheersingsorientatie. In het onderzoek van Seemen en Seeman (1983) blijkt echter dat er na controle van de waarde van gezandheid wel een verband is. Een probleem met het bestuderen van de afzonderlijke preventieve matregelen is, dat de onderzochte gedragingen vaak slecht en van de mogelijke preventieve matregelen vormen. Het is niet uitgesloten dat bepalide groepen ertoe neigen andere preventieve matregelen te nemen den het onderzochte gedrag; zoals geauggereerd is bij het grieponderzoek van Dabbs en Kirscht (1971).

Een betere ingeng voor de relatile tussen de beheersingsorientatie en preventileve matregelen vormt daerom een index van preventieve maatregelen. Zo vonden Seeman en Seeman (1983) met een algemene index voor preventieve matregelen een relatie met de beheersingsorientatie. Intern-georienteerden die de gezondheid belangrijkk vinden; namen namelijk meer preventieve matregelen. Waarschi.jnli,jk is hlerbij de warde van gezondheid relevant, aangezien Wallston en Wallston (1981) geen verband vinden tussen een index van verachillende gezondheidsgedragingen en de beheersingsorientatie. In tegenstelling tot Seeman en Seemen (1983) hielden zij echter geen rekening met de warde van gezondheid.

Vermeldensward is verder nog dat Pill en Stott (1981) in hun onderzoek vinden dat juist degenen die de arts niet zien als de belangrijkste be- 
heersende instantile, overtuigd zijn van de relevantie van de leefwijze voor de gezondheld.

Samenvattend kunnen we zeggen dat er aanwijzingen zijn dat juist interngeorlenteerden meer geneigd zijn preventleve matregelen te nemen, tenminste als $z i j$ gezondheid belangrijk vinden.

\subsubsection{ZIEKTEGEDRAG}

Meinig gegevens zljn bekend over de relatie tussen de beheersingsorientatie en doktersbezoek en medicijngebruik. Krantz e.a. (1980) vonden bij studenten dat degenen met een interne orientatie (vlgs. HLC) minder vaak naar de dokter gaan, vaker zelf de diagnose stellen, en als ze nair de dokter gean, vaker om specifieke medicijnen vragen. Dit komt overeen met hetgeen we eerder zagen in het onderzoek van Clum e.a. (1979) dat interngeorienteerden bij pijn meer geneesmiddelen gebruiken. Waarschijnlijk zijn het juist de intern-georienteerden die dan om medicijnen durven vragen. Ook Seeman en Seeman (1983) wonden dat intern-georienteerden mindex naar de dokter gaan. Deze relatie gold echter alleen voor vrouwen.

Wat betreft de hoeveelheid medicijnen die men gebruikt, vond Baughman (1978) dat personen met een hoge kang-orientatie (CHLC) of een lage interne-arientatie (IHLC) meer medicijnen gebruikten dan de andere respondenten.

Deze gegevens wijzen dus in de richting dat intern-georienteerden minder vaak naar de arts gaan, vaker om specifieke medicijnen vragen, maar over het algemeen minder medicijnen gebruiken.

\subsection{SAMENVATTING EN CONCLUSIE}

Uit de literatuurverkenning in dit hoofdstuk valt op te maken dat onderzoek naar de relatie tussen de beheersingsorientatie en gezondheids- en zliektegedrag nog weinig samenhang vertoont. Vaak gaat het om incidentele onderzoeken, warrbij nauweli.jks rekening gehouden wordt met mogelijke confounders, zoals leeftijd, sociaal-economische status en de gezondhefdstoestand, en met de voorwaarden die volgen uit de sociale leertheorie, met name de waarde die men aan de gezondheld hecht. Van een opeenstapeling van kennis is dus nog nauwelijka sprake.

Enige aanwijzingen zijn er dat extern-georienteerden een lagere sociaaleconomische status hebben, en dat $z i j$ een slechtere gezondheid bezitten. of sexe en leeftijd gerelateerd zijn aan de (gezondheidsspecifieke) beheersingsorientatie is minder duidelijk.

Verder zijn er aanwijzingen dat intern-georienteerden over meer informa- 
tle beschikken, minder naar de dokter gaan, minder medicijnen gebruiken en meer preventieve matregelen nemen. Kans-georienteerden blijken meer alcohol te gebruiken, vooral ondat ze frequenter drinken.

Wat betreft de andere gezondheldsgedragingen zijn er aanwijzingen dat er geen directe relaties beataan met de beheersingsorientatie, maar wel dat er sprake is van indirecte relatiea. Intern-georienteerden blijken name$11 j k$ meer baat te hebben van interventie-programa's welke congruent zijn met een interne orlentatie, terwijl voor extern-georienteerden juist programa's welke congruent zijn met een externe orientatie zinvol zijn. Uit deze gegevens wordt duidelijk dat het van belang is na te gaan of demograffoche kenmerken, en met name leeftijd en sociaal-economische status, gerelateerd zijn aan de beheersingsorientatie, en zodoende mogelijke intervenierende factoren vormen bij de gevonden relaties. We zullen dit in onze studie allexeerst nagaan. 
In het voorgaande hoofdotuk hebben we gezien dat uit resultaten van eerder onderzoek blijkt dat over het algemeen de relatie tussen beheersingsorientatie en gezondheid- en ziektegedrag niet consistent 1s. Zelfs ten aanzien van dezelfde gedragingen werden vaak tegenstrijdige resultaten gevonden. Versichillende redenen zijn hilervoor te noemen.

Allereerat geldt dat er vaak gebruik is gemaakt van verschillende vragenlijsten, waarvan we in hoofdstuk 3 al hebben laten zien dat deze gedeeltelijk verschillende zaken meten. Vervolgens kan opgemerkt worden dat de onderzoeken steeds op verschillende, vaak specifieke, populaties zi.jn uitgevoerd, terwijl veelal geen rekening gehouden is met mogelijke intervenierende factoren welke de onderzochte relaties kunnen versterken of afzwakken, zoals leeftijd en sociaal-economische status. Tot slot kan men meer theoretische argumenten noemen, zoals de situatie moet nieuw of ambigue zijn en de bekrachtiging moet belangrijk gevonden worden.

Hoewel de genoende redenen zeker een deel van de vergchillen in onderzoekaresultaten verklaren, is het de vraeg of deze als verklaring kunnen gelden voor het feit dat valk geen direct verband is gevonden tussen beheersingsorientatle en gezondheidsgedrag.

In dit hoofdatuk zullen we dieper ingaan op de vraag of wel verwacht mag worden dat er een directe relatie bestaat tussen beheersingsorientatie en gezondheids- en zilektegedragingen. In menig onderzoek wordt er min of meer impliciet van uitgegaan dat degenen die van mening zijn dat ze zelf de meeste zaken in de hand hebben (dus intern-georienteerden) zich ook wel gezonder zullen gedragen. Zodoende wordt vexwacht dat bijvoorbeeld intern-georienteerden minder zullen roken. In paragraaf 5.2 zal deze stelling uitgewerkt worden aen de hand van de soclale leertheorile. Vervolgens zal In de paregraaf 5.3 een alternatief gedragamadel en de consequenties hiervan voor de beheersingsorientatie, besproken worden. In de laatate paragraf zullen de vraagatellingen op basis van thet voorgaande geformuleerd worden. Eerst zal echter ingegaan worden op een onderwerp dat voor beide modellen relevant is, namelijk het onderscheid in intentie tot gedrag en het feitielijke gedrag.

\subsection{DNDERSCHEID IN INTENTIE TOT EN FEITEL IJK GEDRAG}

Een belangrijk onderscheid bij gedragamodellen, die voornamelijk gebeseerd zijn op cognitieve processen, is het onderscheid tursen de intentie tot het gedrag en het feitelijke gedrag. Hoewel tussen beide een relatie 
dient te bestean kan de sterkte van deze relatie verschillen.

Al nam gelang het gedragamodel komt een persoon op basis van verachillende overwegingen tot de keuze voor een bepaald gedrag in een bepaalde aituatie. of dit gedrag ook daedwerkelijk uitgevaerd wordt is een andere vraag. Tussen de intentie en de feitelijke ultvoering van een gedrag kunnen verachillende belemmerende of bevorderende factoren een rol spelen. Zo kan de intentie van een roker on te stoppen met roken belemmerd worden doordat hil of $z i j$ verslaafd is aan nicotine, terwijl de intentie van een zieke om vandaag de arts te raadplegen versterkt kan worden doordat zijn of haar kind ook naar de arts moet. Wil men op basis van de overwegingen van een persoon zijn gedrag verklaren, dan is het dus van belang eerst na te gaan of de intentie tot het gedrag verklaard kan worden door deze overwegingen. Aangenomen mag worden dat indien de overwegingen verband houden met het gedrag, dit in eerste instantie teruggevonden wordt bij de intentie.

Voar de beheersingsorientatie is het onderscheid intentie tot en felteIijk gedrag belangrijk ondat het niet is uitgesloten dat de beheersingsorientatlie op twee manieren het uiteindelijke gedrag kan beinvloeden, namelijk door de intentie rechtstreeks te beinvloeden én door de relatie intentie-gedrag te belnvloeden. Als in de literatuur verondersteld wordt dat de beheersingsorientatie het gedrag beirvloedt, wordt meestal alleen de intentie bedoeld. In de volgende paragrafen wordt hier verder op ingegaan.

De beheersingsorientatie kan echter ook invloed hebben op de relatie intentie en uiteindelijk gedrag. Zo lijkt het aannemelijk dat degenen die ven mening zijn dat ze zelf alles in de hand hebben (de intern-georienteerden), de gedragingen die ze van plen zijn ook vaker daadwerkelijk uitvoeren dan degenen die van mening zijn dat alles van externe zaken afhangt. Intern-georlenteerden zullen zich wellicht minder aantrekken van eventule belemmerende factoren en zullen zodoende een grotere overeenkanst wertonen tuasen de intentie en het feitelijke gedrag. Slechts één atudie la hierover bekend, namelijk de reeds eerder genoemde studie van Saltzer (1978) ontrent overgewilcht. Zij vond dat bij intern-georienteerden de intentie wel samenhing met het uiteindelijk gedrag $(r=.56)$, terwijl bij extern-georienteerden geen relatie tussen beide gevonden werd. Dit wijst erop dat de beheeraingaorientatie inderdaad relevent kan zijn voor de relatie tussen de intentie tot en het feitelijk gedrag.

Samenvattend kunnen we zeggen dat een onderscheid gemarkt moet worden tussen de intentle tot gedrag en het feitelijke gedrag. De beheersingsorientatie kan zowel effect hebben op de intentie tot het gedrag als op de relatie tussen de intentie en het feltelijk gedrag. In de volgende paragrafen $z B 1$ met name ingegaan worden op de vraag of de beheersingaorientatie een directe invloed heeft op de intentie tot gezondheids- en ziekte gedrag. 


\subsection{HET MODEL VAN ROTTER}

Volgens de aciale leertheorle van Rotter is gedrag gebaseend op ener$z i j d s$ de verwachting dat op het gedrag een bepalde bekrachtiging volgt en anderzijda dat het individu deze bekrachtiging belangrijk vindt. Gesteld is dat de beheersingsorientatie hierbij relevant kan zljn, mits er sprake $1 . s$ van een ambigue of een nieuwe situatie. In de volgende twee paragrafen zal het model van Rotter uitgewerkt worden voor zowel het zlekte- als het gezondheidsgedrag.

\section{2 .1 ZIEKTEGEDRAG}

Ziektegedrag is de reactie van het individu op ziekte. Diverse gedragamogelijkheden staan het individu daarbij ter beschikking, zoals afwachten hoe de ziekte zich ontwikkelt, extra rust nemen, medicijnen gebruiken, en naar de dokter gaan. Voor welk gedrag het individu klest hangt van verschillende zaken af, waarbij de gepercipieerde ernst waarachljniljk een grote rol speelt. Volgens het model van Rotter zal het individu een afweging maken tussen de diverse gedragsmogelijkkeden. Ervan uitgaande dat de persoon ziljn ziekte onwenselijk acht, en dus beterschap nastreeft (bekrachtiging), zal een keuze gemaakt worden voor het gedrag, warrwan verwacht wordt dat het de bekrachtiging (dus beterachap ofwel gezondheid) het beat realiseert. In sommige situaties kan dit betekenen dat het indiwidu naar de arts gaat, in andere gevallen kan dit betekenen dat het individu uitsluitend extra rust neemt.

Welke rol speelt nu de beheersingsorientatie in dit model? Eerder hebben we gezien dat de beheersingaorientatle de verwachting is door wie af wat invloed uitgeoefend wordt op gebeurtenissen zoals gezondheid, en in welke mate. We kunnen zodoende aannemen dat de beheersingsorientatle met name relevant is voor de keuze van de diverse gedragmogelijkheden. Degenen die van mening zijn dat juist zijzelf invloed kunnen uitoefenen op de eligen gezondheid zullen meer geneigd zijn gedragingen te kiezen welke cen beroep doen op hun elgen vaardigheden, terwijl degenen die met nane de arts invloed toekennen, hun hell zullen zoeken bij de arts. Zowls we in het vorige hoofdstuk gezien hebben komt dit in grote 11 jnen overeen met de bevindingen van Krantz e.A. (1980), Seeman en Seeman (1983) en Baughman (1978). Overigens moet hierbij opgemerkt worden dat de relaties niet echt sterk zijn, hetgeen ook niet verweicht mag worden. De ernst en de duur van de ziekte beperken natuur $11 j k$ de gedragamogelijkheden anzíen1ijkk.

Wat betreft het ziektegedrag kan zodoende werwacht worden dat ex een directe relatie bestaat tussen (de intentie tot) het gedrag en de beheersingsorientatie. 


\section{2 .2 GEZONDHE IDSGEDRAG}

Op basig van het model van Rotter zou men veronderstellen dat degenen die een goede gezondheid belangrijk vinden en verwachten dat ze die met eien bepald gedrag kunnen verkrijgen of behouden, dit gedrag ook zullen uitvoeren. Evenals bij ziektegedrag staen het individu hiervoor verschillende gedraganogelijkheden ter beschikking; zoals stoppen met roken, niet te weel alcohol gebrulken, voldoende ontspenning nemen, goed eten en voldoende slapen. Echter in tegenstelling tot de ziektegedragingen verwijzen de gezondheidsgedragingen alle naar het feit dat men in eerste instantie zelf ietg aan de gezondheld kan doen. Zodoende mag men verwachten dat degenen die van mening zijn dat ze zelf invloed kunnen uitoefenen op hun gezondheid, meer gezondheidsgedragingen zullen wertonen dan degenen die van mening zijn dat met name externe factoren, zoals machtige anderen of kane, hun gezondheid bepalen. Toch blijkt dit niet echt overtuigend uit de diverse onderzoeken, zoals we in het vorige hoofdstuk hebben gezien. Intern-georlenteerden blijken bijwoorbeeld niet minder te raken dan extern-georienteerden.

Diverse problemen zijjn er aan het model van Rotter te onderkennen wat betreft de toepasbaarheld bij gezondheidsgedrag.

Allereerst is de bekrachtiging minder duidelijk dan bij zilektegedrag. Hoewel bij ziektegedrag ook andere bekrachtiglingen zoals zlekteverlof een rol kunnen spelen, zullen in het merendeel van de gevallen deze activiteiten ondernomen worden om de bekrachtiging "gezondheid" te verkrijgen. Bij gezondheldagedragingen is dit veel minder duidelijk. Er wordt wel al$t 1 j d$ gesteld dat men moet stoppen met roken, niet te veel moet drinken en voldoende lichaamsbeweging moet nemen ter bevordering van de gezondheid, de vraag is echter of dit ook daadwerkelijk de belangrijkste reden (bekrachtiging) vormt voor mensen om deze gedragingen uit te voeren. Het effect van gezondheldagedrag treedt pas na jaren op en dan nog zal het niet duldellyk zljn of de gezondheid een gevolg $\mathrm{is}$ van het desbetreffende gedrag. De waarde van gezondheid als motivator om zich gezonder te gedragen 1. warschijnlijk beperkt. Naast gezondheid kunnen ook andere bekrachtigingen een ral spelen. Bijvoorbeeld bij het stoppen met roken kan van belang zljn dat men lichamelijke beperkingen ervart bij het sporten of dat de omgeving impliciet of expliciet andringt op stoppen. Soortgelijke redenen of bekrachtigingen zijn te bedenken voor lichaamsbeweging (te dikke bulk, soclale contecten) of het minderen van alcoholgebruik (te dikke buik, sociale druk, te vaak een kater, niet uitgerust wakker worden). Gezondheld vornt dus niet de enige en wellicht ook niet de belangrijkste bekrachtiging van gezondheidsgedragingen. Dit maakt dat het model van Rotter minder bruikbaar; is voor gezondheidsgedrag, aangezien Ratter er min of meer impliciet vanuit gaat dat op gedragingen slechts én bekrachtiging volgt. Dit betekent ook dat er geen duidelijke relatie verwacht meg worden tussen een gezondheidsspecifieke beheersingsorientatie en ge 
zondheidsgedrag. Als dergelijke gedragingen niet voornamelijk gebaseerd zijn op de bekrachtiging gezondheid, dan valt elke legitimatie weg on te veronderstellen dat degenen die van mening zijn dat vooral zijzelf veel aan de gezondheid kunnen doen, meer van dergelijke gedragingen zullen vertonen.

Een ander probleem van het model, dat vooral blj gezondheldagedragingen naar voren kant, is dat de gebruikte variabelen vaak een verschillende mate van specificiteit hebben. Vaak worden gedragingen specifiek gemeten, terwijl de beheersingsorientatie en de warde van de bekrachtiging min of meer algemeen worden gemeten, bijwoorbeeld als het stoppen met roken gerelateerd wordt aan de warde van gezondheid en de (gezondheidsipecifieke) beheersingsorientatie. Diverse auteurs (Fishbein en Ajzen, 1975, Kok, 1978) laten zien dat dit mogelijke relaties tusaen variabelen ernstig kan verstoren. Dit niveau-verschil kan opgeheven worden door of de beheersingsorientatie en de waarde van de bekrachtiging specifleker te meten, bijvoorbeeld door als bekrachtiging te nemen het. krijgen van longkanker in de toekomat, of door het gedrag algemener te meten bijvoorbeeld door een schaal of een index van gezondheidagedragingen te nemen.

Hiermee komen we tevens op een volgend probleem, namelijkk of er wel zolets bestaat als "gezondheidsgedragingen". De term suggereert dat deze gedragingen met elkar gemeen hebben det ze om gezondheidaredenen verricht worden. Eerder hebben we al gesteld dat gezondheid echter niet de enige bekrachtiging is voor deze gedragingen. We kunnen ons daarom afvragen of het wel correct is deze gedragingen op te vatten als een groep soortgelljke gedragingen. Utt diverse studies (Langlie, 1979; Steele en McBroom, 1972;) blijkt dat deze gedragingen slechts in zeer beperkte mate onderling samenhangen. Zo zijn verschillende pogingen gedaan am een schal te construeren. Meestal resulteerde dat echter in zeer lage interne betrouwbaarheden (Steele en McBroom, 1972; Langlie, 1979; Mechanic en Cleary, 1980). Kristiansen (1985) vond wel een schaal met een redelijke interne betrouwbaarheid, maar items over rookgedrag, en lichaamabeweging moesten wegens een te lage correlatie uit de achaal verwijderd worden. Duidelijk is dus dat hoewel de gedragingen well lets met elkaar te maken hebben (Langlie, 1979), de onderllinge samenhang tussen de gedragingen minder sterk is dan de term gezondheidsgedragingen suggereert.

Samenvattend kunnen we zeggen dat het model van Rotter bij toepassing op gezondheidsgedragingen minder bruikbaar is, niet alleen ondat er vaak aprake is van een verschil in specificiteit, maar met name amdat deze gedragingen niet alleen gebaseerd zijn op het behoud en of verkrijgen van gezondheid, marr ook op andere bekrachtigingen. Dit uit zich onder andere in het feit dat deze gedragingen onderling weinig samenhangen.

Een model dat beter arnsiluit bij het gezondheidagedrag is het model van Fiahbein en Ajzen (1975), aangezien in dit model éen gedrag verklaard wordt aan de hand van verachillende bekrachtigingen. 
Fisfibein en Ajzen (1975) en Ajzen en Fishbeln, (1980) gaan uit van bewust en beredeneerd gedrag. Valgens hen is gedrag het best te voorspellen uit de intentie tot dat gedrag. In paragraaf $5.2 \mathrm{zi}$ jn we hier al op ingegaan. Gesteld is dat de intentie en het feitelijk gedrag niet altijd in overeenstemming zijn met elkar, doordat er verschillende belemmerende factoren een rol kunnen apelen. Bijvoorbeeld een individu kan wel van plan zijn om te stoppen met roken, maar in dit streven beperkt worden door verslavingaver achijngelen (zie Kok en De Vries, 1985).

De intentie wordt op haar beurt volgens het model van Fishbein en Ajzen bepald door wet name twee factoren: de attitude en de subjectieve normen ten opzichte van dat gedrag (zie fig. 5.1.). De attitude is hierbij de affectieve evaluatle van het gedrag, terwijl de subjectieve nomen betrekking hebben op de vraag: denkt het individu dat belangrijke anderen vinden dat $h i j$ of $z i j$ dat gedrag moet vertonen of niet? Bijwoorbeeld de intentie on te roken kan volgens dit model het best voorspeld worden uit de attitude ten opzichte van roken (bijwoorbeeld roken vind ik goed, prettig) en de aubjectieve norm ten opzichte van roken (bijvoorbeeld mijn vrouw en mijn arts vinden dat ik niet moet roken).

Volgens Flshbein en Ajzen wordt de attitude gevormd door enerzijds de verwachting dat er een relatie is tussen het gedrag en enkele kennerken (waarschijnlijkheden of "beliefs" genoemd), en anderzijds door de evaluatie van deze kenmerken. Een negatleve attitude ten opzichte van roken kan dus gebaseerd ziljn op waarschijnlijkheden, zoals roken leidt tot longkanker of tot misselijkheid, en een negatieve evaluatie van deze kenmerken.

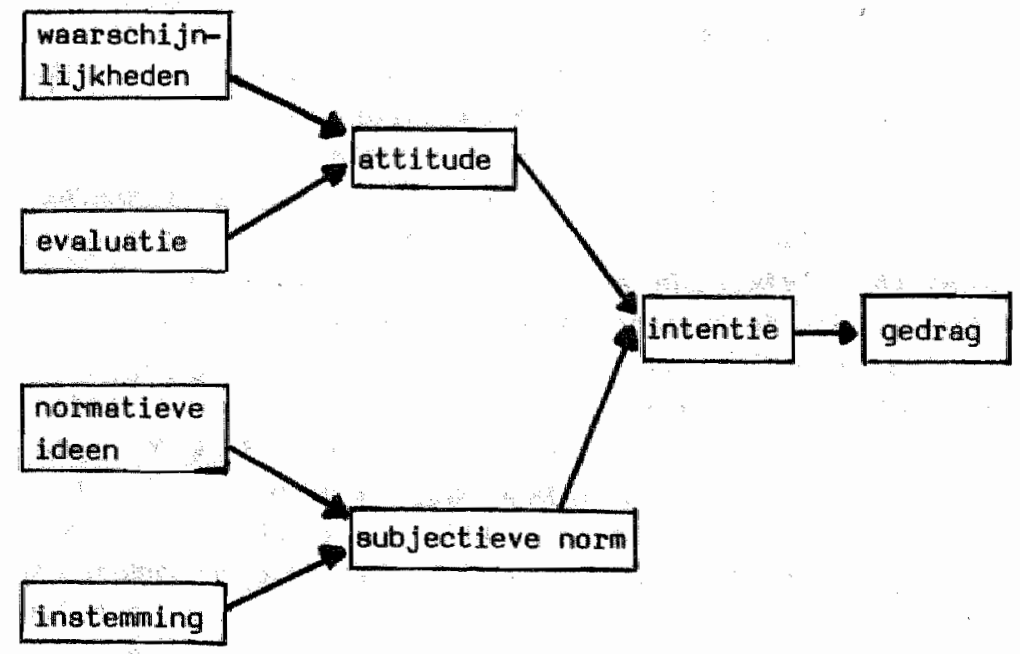

Fig. 5.1 Het madel van Fishbein en AJzen 
Op soortgelijke wijze kont de subjectieve norm tot stand. Enerzljjds op basis van de menling van het individu dat anderen denken dat hij of zij al of niet het gedrag moet vertonen (het norm-idee), en anderzijds op besis van de mate waerin het individu instemt met de mening van anderen (insteming). Een negatieve subjectieve norm kan dus gebaseerd zijn op de mening van het individu dat zijn vrouw, zijn arts en zijn collega" g vinden dat hij niet moet roken, en het feit dat hij of zij de mening van deze personen belangrijuk vindt.

Samenvattend kunnen we zeggen dat volgens het model van Fishbein en $A J-$ zen, de attitude en de subjectieve norm de intentie tot gedrag verklaren, welke op haar beurt het uiteindelijke gedrag het best verklaart.

De mate waxin de attitude en de subjectieve norm het gedrag verklaren kan per gedrag verschillen. Volgens Kok e.a., (1981) ls hierbij van belang in hoeverre het gedrag zichtbaar is. Anonien gedrag zal nauwelijks beinvloed worden door subjectieve normen inzoverre deze afwijken van de eigen attitude. Zo winden Kok e.a. (1981) dat attitudes een grotere invloed hebben op anoniem dan op publiek gedrag, terwijl de subjectieve normen een grotere invloed hebben op publiek dan op anoniem gedrag. Niet alleen per gedrag, maar oak per individu kunnen er verschillen zijn in de mate warin de attitude en de subjectieve normen het gedrag beinvloeden. Sommigen zullen hun gedrag meer baseren op de attitude, terwijl anderen hun gedrag meer zullen baseren op de subjectieve normen. Met name kan de beheersingsorientatie hierbij relevant zijh. Verwacht mag worden dat intern-georienteerden hun gedrag voornamelijk bageren op de eigen attitude, aangezien juist zij van mening zijn dat gebeurtenissen door hen zelf beheerst kunnen worden. Indien zij bijvoorbeeld de verwachte gevolgen van roken negatief beoordelen en zodoende een negatieve attitude hebben ten aanzien van roken, mag verwacht worden dat zij een hogere intentie hebben tot stoppen dan degenen met een lage interne orientatie, asngezien de laataten minder van menilng zijjn dat ze lets aan deze gevolgen kunnen doen.

Het omgekeerde kan gelden voor de machtige-anderen-georienteerden. Van hen mag verwacht worden dat ze hun intentie juist bepalen aan de hand wan wat belangrijke anderen winden over dat gedreg, aangezien $z i j$ van mening zIjn dat gebeurtenisaen vooral door anderen beinvloed kunnen worden. Zij zullen dan ook eerder hun gedrag afstemmen op hetgeen die belangrijke anderen volgens hen vinden van dat gedrag. Eerder hebben we gewezen op een studie van Saltzer (1978), die het bovenstaande bevestigde. Interngeorlenteerden bleken aan de hand van hun attitude te bepalen of $z \mathbb{1 j}$ deel zouden nemen aan een falankcursus, terw1jl extern-georienteerden dit deden aan de hand van hun subjectieve normen.

Dit betekent dat bij intern- en extern-georienteerden (de intentie tot) gedrag op een verschillende wijze tot atand komt. Dit ls ook in overeenstenming met hetgeen we in hoofdstuk 4 concludeerden. U⿻上丨 verschillende interventiestudies bleek dat interventies pas aucces hebben, als voor intern- en extern-georienteerden een verschillend interventieprogramma gebruikt werd. 
Als bij intern- en extern-georienteerden het gedrag op verschillende wijze tot atand kont, betekent dit ook det voorspellingen als intern-georienteerden toppen eerder met roken dan extern-georienteerden niet op voothand te maken zijn. Extern-georienteerden kunnen ook stoppen met roken of de intentie dartoe hebben, mar dit zou dan meer gebaaeerd zijn op hetgeen voor hen belangr 1jke personen vinden van hun rookgedrag. Behalve dat de beheeraingsorientatie invloed kan hebben op de wijze warop de intentie tot stand komt, kan deze ook direct van invloed zijn ap de attitude en de subjectieve norm. Zo kunnen bijvoorbeeld interm-georienteerden een negatlevere houding hebben ten aenzien van roken, of meer het idee hebben dat voor hen belangrijke personen negatief staan ten opzichte van roken. Echter op voorhand $z i j n$ er geen redenen te bedenken waarom intern- en extern-georienteerden zouden verschillen wat betreft de attitude en de aubjectieve norm ten aanzilen van bijwoorbeeld roken.

Samenvattend kunnen ze zeggen dat valgens het model van Fishbein en Ajzen gedrag het best voorspeld kan worden op basis van de intentie tot dat gedrag, terwijl de intentie op haar beurt voorspeld of verklaard kan worden door de attitude en de subjectieve norm ten aanzien van dat gedrag. In welke mate de attitude en de subjectieve norm bijdragen aan het tot stand komen van de intentie, kan per gedrag en per individu verschillen. Verwacht mag worden dat intern georienteerden hun intentie vooral zullen bageren op de attitude, terwijl degenen met een machtige anderen orientatie hun gedrag vooral zullen baseren op de subjectieve normen.

\subsection{VRAAGSTELLINGEN}

In dit hoofdatuk $z i j n$ verschillende punten genoemd welke relevant kurinen zijn voor de relatie tussen beheersingsorientatie en gezondheids- en zlektegedrag. Zo ia gesteld dat de intentie tot gedrag onderacheiden moet worden van het feitelijk gedrag ondat de beheersingsorientatie van invloed kan zijn op zowel de intentie als op de rellatie tussen de intentie en het feitelijk gedrag. Van belang hierbij is dat rekening gehouden wordt met de warde die men hecht aan gezondheid, aangezlen de beheeraingaorlentatie volgens Rotter alleen van invloed is op gedrag indien men de bekrachtiging belangrijk vindt. Hoewel dit model wel geschikt $11 j k t$ voor ziektegedrag, zijn er verachillende redenen genoemd waarom het voor gezondheldsgedrag minder geschikt is. Zo $1 \mathrm{~s}$ er een verschil in niveau tussen de beheersingsorientatie en het specifieke gedrag, hetgeen vooral bij gezondheidsgedragingen wan belang is omdat hier meerdere bekrachtigingen een rol kunnen spelen. Mocht er een directe relatie bestaen tussen beheersingsorientatie en gezondheidsgedrag, dan moet deze tot uitdrukking komen alg beide van gelijk niveau zijn. Een prableem hierbij is echter of gezondheidsgedragingen wel te sommeren zijn tat én schaal. Verder is ge- 
suggereerd dat intern- en extern-georienteerden op verschillende wijzen hun (intentie tot) gedrag bepalen, namelijk intern-georienteerden aan de hand van hun attituden en extern-georienteerden aan de hand van hun aubjectieve normen.

Alvorens deze punten nader kunnen onderzoeken, moet inzicht verkregen worden in de relatie tussen de beheersingsorientatie, en demografische kenmerken en de beheersingsorientatie en de subjectieve gezondheld, aangezien denografische kenmerken en subjectieve gezondheidatoestand mogelijk als intervenierende factoren kunnen optreden.

Zodoende zijn de volgende vraagstellingen voor het onderzoek geformuleerd:

\section{Intervenierende factoren}

1. Hangt beheersingsorientatie samen met demografische kenmerken en met subjectieve gezondheidstoestand?

Model van Rotter

2. Hangt de beheersingsorientatie samen met (de intentile tot) gezondheids- en zlektegedrag?

3. Is de warde van gezondheid van invloed op de samenhang tusaen de beheersingsorientatie en (de intentie tot) gezondheids- en ziektegedrag?

4. Hangt de beheersingsorientatie samen met een algemene maat voor gezondheidagedrag (vooropgeateld dat een dergelijke mat samengesteld kan worden)?

\section{Relatie Intentie-Gedrag}

5. Is de beheersingsorientatie van invloed op de samenhang tussen de intentie tot en het feitelijk gezondheids- en ziektegedrag?

Madel van Flishbein en Ajzen

6. Is de samenhang tusgen de attitude ten opzichte van een specifliek gezondheidagedrag en de intentlie tot dit gedrag sterker bij lintern-georilenteerden dan bij extern-georienteerden?

7. Is de samenhang tussen de subjectieve norm ten opzichte van een specifiek gezondheidagedrag en de intentle tot dit gedrag aterker bij extern-georienteerden dan bij intern-georienteerden?

Indien bij de beantwoording van vraagstelling 1 blijkt dat de beheersingsorientatie samenhangt met een of meerdere denografiache kennerken; zal bij de beantwoording van vraagstelling 2 tot en met 7 via contrôle op deze kemerken, hun rol als intervenierende factoren worden geëlimineerd. 
In dit hoofdatuk worden de opzet, de respandenten en de variabelen van het onderzoek besproken.

\subsection{DE OPZET}

Het onderzoek is onderdeel van een panelonderzoek dat in uitloop van een onderzoek nar de subjectieve gezondheidstoestand, de gezondheidsopvattingen en de leefwijze van de Nederlandse bevolking, verricht werd, en warbij gebruik werd gemaakt van gestandaardiseerde vragenlijsten (Adriaense e.a., 1981; Halfens e.a., 1984).

Deze anderzoeksopzet bood verschillende voordelen. Allereerst kon een meetinstrument geconstrueerd worden op een heterogene populatie, waardoor deze in meerdere populaties bruikbaar is. Tot nu toe werd de relatie tursen beheersingaorientatie en gezondheids- en ziektegedrag voornamelijk bestudeerd in een vrij homogene populatie. Door in dit onderzoek gebruik te maken van een heterogene populatie kon inzicht worden verkregen in verschillen in beheersingsorientatie tussen groepen binnen de bevolking, en kon nagegaan worden of de relatie tusaen beheersingsorientatie en gezondheido- en ziektegedrag beinvloed wordt door denografische kenmerken, zoals leeftijd, sexe en sociaal-economische status. Tot slot bood deze onderzoeksopzet het voordeel dat juist door het panel-karakter van het onderzoek de vragenlijat bij de tweede meting verder aangescherpt kon worden en dat inzicht verkregen kon worden in mogelijke selectie-bias. Naidelen van een dergelijke opzet zijn echter dat samenhangen wat minder aterk worden, zodat het onderzoek naar de verschillende modellen wat minder acherp wordt, dat niet alle wenselijk geachte variabelen kunnen worden opgenomen om de respondenten niet al te zeer te belasten, en dat alleen relaties bestudeerd kunnen worden met bestaand ziekte- en gezondheldegedrag.

\subsubsection{HET PANELONDERZOEK}

De eerste meting van het panelonderzoek is, in opdracht van de stichting Nederland Oke, in het voorjaar van 1981 door de Rijksuniveraiteit Limburg. uitgevoerd. Doel van deze meting was een indicatie te krijgen van de aubjectleve gezondheidstoestand, de gezondheidsopvattingen en de leefwijze 
van de Nederlandse bevolking (Adriaense e.a., 1981). Hiervoor zijn, aan de hand van een gestructureerde vrageniljst, door getrainde enqueteurs en enquetrices van een extern bureau een viertal steekproeven uit de volgende populatles geinterviewd:

\section{Algemene bevolking:}

2. Niet-actieven:

alle personen in Nederlend in de leeftijd van 21 $t / \mathrm{m} 64$ jaar, levend in hulishoudingen;

alle personen in Nederland in de leeftijd wan 21 $t / m 64$ jaar, levend in hulshoudingen en welke of 6 maanden of langer werkloos zijn, of 3 maanden of langer ziek, of gepensloneerd, rentenler of arbeidsongeschikt zijin;

3. Onderwijs: a le onderwijskrachten in Nederland verbonden wan een kleuter- of basisschool;

4. Gezondheidszorg:

Alle practizerende hulsartsen, wijkverpleegkundigen en maatschappeli.jk werkenden in Nederland.

De steekproeven $z \not, j n$ ad random getrokken. Voor een uitvoerige beachrijving hiervan en voor de resultaten van dit onderzoek verwijzen we naar het verslag, welk in 1981 is uitgebracht (Adriaanse e.a.).

Medio 1982 is besloten het onderzoek voort te zetten als een penelonderzoek, waarbij de meting van 1981 opgevat werd als de eerste meting.

Panelanderzoek ia een bijzondere vorm van longitudinaal onderzoek, en wordt gekenmerkt door een tweetal eigenachappen. Het betreft een herhalde meting bij dezelfde individuen en deze herhaalde meting moet betrekking hebben op dezelfde kenmerken. Met penelonderzoek kan men dus niet alleen na verloop van tijd veranderingen van kenmerken vaststellen, tevens kan men, omdat deze veranderingen per individu gemeten ziljn, nagaan of deze veranderingen samenhangen met veranderingen van andere individuele kenmerken.

Het doel van het penelonderzoek wes tweeledig. Enerzijdo inzicht krijgen in samenhangen tussen de subjectleve gezondhaidstoestand, gezondheidsopvattingen en leefwljze, en anderzijds inzicht kxijgen in asmenhangen tussen veranderingen. Zo kan met een dergelijke opzet nagegaan worden of een verandering in leefwilge samenhangt met een verandering in de subjectieve gezondheidstoestand.

Als respondenten voor dit penelonderzoek zijn alleen de respondenten ult de steekproef "algemene bevolking" en de steekproef "nilet-actieven" herbenaderd. De respondenten uit de belde andere steekproeven $21 . j n$ voor een ander onderzoek opnleuw benaderd (Adriaanae e.a., 1984).

Een belangrijk probleem bij penelonderzoek is de panelnortalitelt. TIjdens de duur van een panelonderzoek zullen om uilteenlopende redenen zoals verhuizing, overlijden en weigering, respondenten uitvallen. Dit betekent dat een panel na verloop van tijd zodanig ia verkleind, dat het geen zinvalle basis meer vormt voor verdere analyses.

on te voorkomen dat het panel vroegtijdig uitsterft, ia besloten bi.j elke 
nieuweting het panel an te wullen met een nieuwe steekproef, getrokken ut de belde, eerder genoende, populaties. Deze worden in de daropvolgende meting an het panel toegevoegd.

op dit moment zijn twee metingen gereallseerd, namelijk de meting uit 1981 en een nuevwe neting in 1983.

In $1981 \mathrm{z} / \mathrm{jm}$ in total $127 \mathrm{~g}$ respondenten uit de steekproef algemene bevolking geinterviewd, hetgeen overeenkwam met een response van $73 \%$. $882 *$ van deze reapondenten bleken in 1983 opnieuw geinterviewd te kunnen worderi. On utteenlopende redenen, zoals weigering, vakantie, foutief adres en 21 lekte, heeft er dus een uitval van 396 respondenten (31\%) plaatsgevonden (zie paragraaf 6.2 .1 ). Daarnaest is in 1983 een nieuwe steekproef getrokken, warvan uiteindelijk $311^{*}$ respondenten geinterviewd $z i j n$, hetgeen een regponse is van 58\%. Voor de niet-actieven geldt eenzelfde opzet. Van de 247 reepondenten uit 1981 (response $=76 \%$ ), zijn er 153 in 1983 opnieuw geinterviewd, terwijl er in 1983 tevens 100 respondenten (reaponse $=76 \%$ ) uit een nieuwe steekproef geinterviewd zijn.

De respondenten $z 1 j n$ geinterviewd met behulp van gestructureerde vragen11jaten. De interviews hadden een gemiddelde dur van vijf kwartier. De in 1981 gebruikte vragenlifat bevatte, behalve vragen naar achtergrondkenmerken, voomamelijk vragen omtrent de volgende drie hoofdthema" $\mathrm{s}$ :

1. de subjectleve gezondheidstoestand;

2. de gezondheldsopvettingen, zowel ontrent de eigen gezondheid als die van anderen:

3. leefwijzen, namelijk roken, alcoholcansumptie, lichaamsbeweging, geneesmiddelengebruik, voeding en veiligheid.

Aangezien het bij panelonderzoek van belang is dat steeds dezelfde metingen worden verricht zijn in 1983 een groot deel van de in 1981 gestelde vragen opnleuw gebruikt. Om verschillende redenen zijn de gezondheidsopvattingen ontrent de gezondheid van anderen, evenals vragen omtrent voeding en velligheld in 1983 niet meer in de vragenlijst opgenomen. Daarvoor In de plaato 1 dieper ingegaan op het ziektegedrag en het rook- en drinkgedrag. Voor de detalls over de gebruikte vragenlijat verwijzen we naar Adriaange e.e.(1981) en Hallfens e.a. (1964).

* In Helfens e.0. (1984) staan reapectievelijk de aantallen 884 en 309 vermeld. Nadere analyoe leerde echter dat bij het panel in twee gevallen abuslievel1.jk een verkeerde respondent was geinterviewd. Beiden zijn hier toegevoegd aan de nleuwe steekproef. Overigens zal dit de gevonden resultaten weinig of niet beinvloed hebben. 


\subsection{DE RESPONDENTEN}

Uit het hierboven beschreven panelonderzoek zullen in deze studle alleen de 882 respondenten uit het panel algemene bevolking wan 1983 gebruikt worden. De respondenten uit de nieuwe steekproef uit 1983 zullen voor deze studie niet gebruikt worden, aangezien van deze respondenten geen gegevens uit 1981 bekend zijn. De gegevens van de niet-actieven zullen in andere publicaties beachreven worden.

Een verdere inperking van het eantal respondenten zal op het elind van deze paragraaf gegeven worden.

\subsubsection{REPRESENTATIVITEIT VAN HET PANEL}

Bij gebruik van gegevens van panelonder zoek verdient het vraagstuk van de representativiteit extra andacht. Bij vrijwel elke meting zal er in meerdere of mindere mate non-response optreden, zodat na enkele metingen de vraag gesteld moet worden of het resterende panel nog wel opgevat mag worden als representatief voor de totale populatie.

On enig zicht te krijgen op de representativiteit van het door ons gebruikte panel, 1 s een vergelijking gemaakt naar enkele achtergrondgegevens tusien de reapondenten in 1981 en 1983, en de - door het CBS vrij nauwkeurig op basis van het woningbehoefte-anderzoek (1981;n=173.468) geschatte - Nederlandse populatie van personen woonachtig in huishoudens (zile tabel 6.1). Uit deze vergelijking blijkt dat mannen, en personen in de leeftijdaklasse 20 tot en met 24 jaar, in de steekproef van 1981 ondervertegenwoordigd zijjn in vergelijking met de geachatte populatie. Vroumen daarentegen en personen wan 60 jaar en ouder zijn in deze steekproef overwertegenwoordigd. De enigszins acheve verdeling natar geslacht. is in de steekproef van 1983 lets gecorrigeerd. De acheve verdeling nar: leeftijd heeft zich echter voortgezet.

Wit tabel 6.1 blijkt verder dat ongehuwden ondervertegenwoordigd $z i j n$. Nadere analyse leert echter dat dit voornamelijk moet worden toegeschreven aam de ondervertegenwoordiging van de leeftijdaklasse 20 tot en met 24. Jaar. Ongehuwden in deze leeftijdaklasse vormen $L_{1}$ \% van de populatie tussen de 20 en 65 jaar, terwijl ze in het panel slechta met $4.2 \%$ vertegenwoordigd zijn.

Uit nadere analyses blijkt ook dat mannen in de leeftijdacategorie 30 tot en met 34 jaar in de steekproef van 1981 enigszins oververtegenwoordigd zijn (18.6\% versus $14.8 \%$ in de populatie), hetgeen zich in 1983 verder heeft doorgezet $(20.4 \%)$. Deze oververtegenwoordiging geldt vooral voor gehuwde mannen. 
Tabel 6.1 Kenmerken van de populatie vergeleken met die van de reapondenten (in percentages; gebases op de gegevens van 1981).

$\begin{array}{llll}\text { populatie } & \text { responge } & \text { reaponse } & \text { abs. } \\ 1981 & 1983 & \text { aantal } \\ & & & 1983\end{array}$

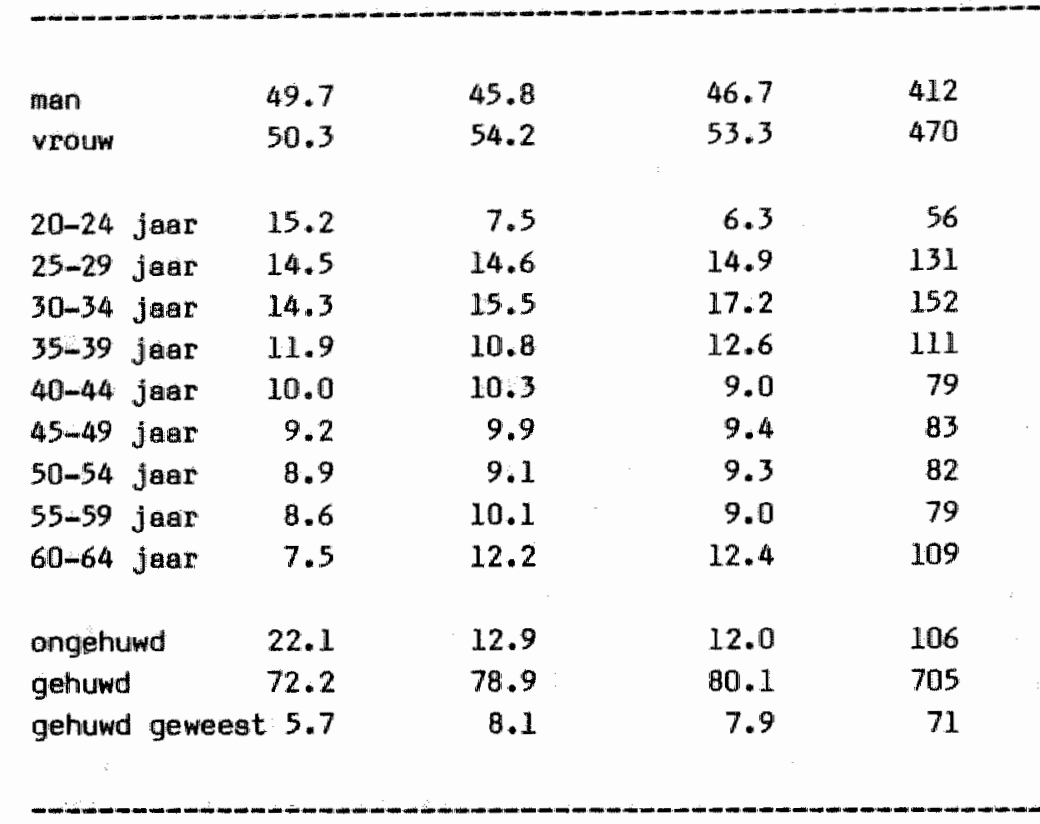

Een vergelijking naar sociaal-economigche status is niet mogelijk, ondat hierover geen gegevens beachikbaar $z i j n$ van de populatle.

Samenvattend künnen we zeggen dat wrouwen, personen ouder dan 60 jear, en gehuwde mannen in de leeftijdaklasse 30 tot 34 jaar in het panel oververtegenwoordigd zijn. Dngehuwden tussen de 20 en 24 jaar zijn ondervertegenwoordigd. Deze fifljkingen worden echter aanvaardbaar geacht ondat een precleze schatting van het voorkomen van een bepeald kenmerk voor dit onderzoek minder belangrijk is en het ook niet de bedoeling is een normenlijat van enige schaal op te stellen.

Respondenten kunnen door een tweetal factoren een minder getrouwe afspiegeling van de feitelijke populatie vormen. Allereerst kan de getrokken steekproef een vertekening van de feitelijke populatie geven. Naarmate de grootte van een steekproef toeneemt zal de kans hierop echter afnemen. Een tweede vertekening kan ontstaan door uitval van personer uit de 
ateekproef, bijwoorbeeld door weigering of afwezigheid. Met name deze factor is tegenmoordig belangrijk geworden door de afgenomen bereidwilligheid on met onderzoek mee te werken. Nu non-response percentages als 30 of $40 \%$ algemeen goed zijn geworden, is de vraag naar de kenmerken van deze uitval minstens zo belangrijk geworden als de representativiteit van de reaponse (Philipsen, 1984). Het name is van belang of de non-response samenhangt met een of meerdere van de onderzoeksvariabelen. Zo zou het kunnen $z i j n$ dat zij die extern-georienteerd $z i j n$ of gezondheid minder belangrijk vinden, minder genegen zijn aan een gezondheidsenquête mee te doen. Een dergelijke response-bies zou de distributie van de antwoorden en de samenhang tussen verachillende variabelen ernstig kunnen beinvloeden. Een groot probleem bij onderzoek naar deze groep is echter dat de uitval of non-response julst gekenmerkt wordt door het feit dat ze niet geinterviewd willen of kunnen worden. Een vergelijking van de onderzoekgvariabelen met die van de response behoort daarom vrijwel altijd tot de onmogelijkheden.

Panelonderzoek biedt hiertoe ten dele mogelijkheden, mangezien er aprake is van een getrapte non-response. Hoewel meestal nlets gezegd kan worden over de non-response die is opgetreden tijdens de eerste meting, kan wel lets gezegd worden over de non-response die optreedt bij valgende metingen, aangezilen hiervan gegevens bekend zijn uit de voorgaande meting(en). Voor deze atudie betekent $d i t$, dat de non-reaponse die is opgetreden bij de tweede meting (1983), vergeleken kan worden met de response op basis van de gegevens uilt 1981 .

Een onderscheid moet hierbij worden gemakt tussen non-respondenten, die niet geinterviewd willen worden - weigeringen om uiteenlopende reden ( $\mathrm{n}=$ 249) -, en non-respondenten die niet geinterviewd kunnen worden - vakantie, foutief adres of verhuisd $(n=147)$ - (Swanborn, 1981). Voor deze studie lijkt een verdere splitsing van de tweede categorie zinvol in nonrespondenten, die on gezondheidsredenen inclusief overlijden, niet gelnterviewd zijn $(n=22)$, en nor-respondenten die on andere redenen niet geInterviewd kunnen worden $(n=125)$.

Allereerst is nagegaan of deze drie categorieen non-respondenten verschillen van de respondenten op enkele achtergrondgegevens (zie tabel 6.2).

Uit deze tabel blijkt dat de non-response afwijkt wat betreft soclaaleconomische status, burgerlijke staat en leeftijd. Degenen die on gezondheldsreden in 1983 niet geinterviewd zijn (I), hebben een lagere sociaaleconomische status, en zijn over het algemeen ouder dan de respondenten. Degenen die om andere reden niet geinterviewd konden worden (II), zijn lets Janger, hebben lets vaker een lagere social-economische statius en zijn vaker niet (meer) gehuwd.

Opmerkelijk is dat de welgeraars (III) nauwelijks verschillen van de reopondenten. 
Tabel 6.2 Non-response en response uit 1983 vergeleken naar geslacht, burgerlijke staat, sociaal-economische status en leeftijd (1981).

\begin{tabular}{|c|c|c|c|}
\hline & onrespons & 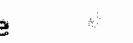 & response \\
\hline I" & II II & III' & IV \\
\hline 22) & $(n=125)$ & $(n=249)$ & $(n=882)$ \\
\hline
\end{tabular}

geslacht

\begin{tabular}{lllll}
\hline man & $55 \%$ & $43 \%$ & $43 \%$ & $47 \%$ \\
vrouw & $45 \%$ & $57 \%$ & $57 \%$ & $53 \%$ \\
$x 2$ & .26 & .41 & 1.18 &
\end{tabular}

soc. ec. status

\begin{tabular}{lllll}
\hline laag & $77 \% *$ & $62 \% * *$ & $56 \%$ & $49 \%$ \\
midden & $0 \%$ & $24 \%$ & $18 \%$ & $24 \%$ \\
hoog & $23 \%$ & $14 \%$ & $26 \%$ & $27 \%$ \\
$\times 2$ & $9.01 *$ & $10.37 * *$ & 4.98 &
\end{tabular}

burgerlijke staat

$\begin{array}{lllll}\text { gehuwd/samenwonend } & 86 \% & 75 \% & 83 \% & 83 \% \\ \text { niet (meer) gehuwd } & 14 \% & 25 \% & 17 \% & 17 \% \\ \times 2 & .02 & 5.71 & .00 & \end{array}$

leefti.jd

\begin{tabular}{lllll}
\hline gemiddelde & $52 * * *$ & $39 *$ & 43 & 41.4 \\
standaard deviatie & 10.8 & 13.9 & 12.4 & 12.7 \\
$F$ & $15.25 * * *$ & $5.09 *$ & 3.21 &
\end{tabular}

non-reaponse wi.jkt of van de response:

* p kleiner dan .05

* p kleiner dan .01

*** p kleiner dan .001

- 1 = on gezondheidareden

- II = niet bereikbaar

- III = welgeringen e.d. 
Voor de response-bias zijn echter niet zozeer de demografiache wariabelen van belang, maar juist de onderzoeksvarlabelen. Met behulp van discriminant-anal yee $z 1 j \mathrm{jn}$ dearom de non-respondenten wergeleken met de respondenten op de gezondheidsbeleving, de gezondheidsopvattingen en enkele gezondheidsgedragingen.

Opgenerkt moet worden dat een aantal relevante variabelen, waaronder de gezondheidsspecifieke beheersingsorientatie, in deze analyse niet meegenomen zijn om de eenvoudige reden dat deze in 1981 nog niet in de vragenlijst waren opgenomen.

Voor elke vergelijking is een stapsigewijze discriminant-analyse uitgevoerd. Hiervoor zijn de volgende variabelen gebruikt:

$\begin{array}{ll}\text { 1. Achtergrondgegevens } & \text { - leeftijd } \\ & \text { - sociaal-economische status } \\ & \text { - gehuwd en samenwonend } \\ \text { 2. Gezondheidstoestand } & \text { - cantal klachten (voeg) } \\ \text { 3. Opvattingen } & \text { - interne beheersingsorientatie } \\ & \text { - externe beheersingsorientatie } \\ & \text { - beinvloeding eigen gezondheid } \\ & \text { - waarde van gezondheid } \\ & \text { - lichaamsbeweging (log) } \\ \text { 4. Cezondheidagedrag } & \text { - roken } \\ & \text { - alcoholgebruik } \\ & \text { - doktersbezoek } \\ \text { 5. Ziektegedrag } & \text { - aantal medicijnen (log) }\end{array}$

Voor een beschrijuing van deze variabelen verwijzen we naar bljlage 3 . Vervolgens is met de best onderscheldende variabelen een directe discriminant analyse uitgevoerd. In tabel 6.3 zijn de gestandaardiaeerde discriminant coefficienten van deze directe analyses voor de vergelijking nonrespondenten wegens gezondheldredenen versus respondenten, weergegevien.

Uit deze analyse blijkt dat degenen die on gezondheldaredenen nlet geinterviewd konden worden, niet alleen verachillen van de respondenten qua leeftijd en sociaal-economische status, maar ook wat betreft een aantal andere kenmerken. Zo hechten zij meer waarde aan gezondheid, bezoeken vaker de dokter hoewel ze relatief minder klachten hebben, doen minder aan lichaamsbeweging, roken vaker, en zijn minder van mening dat ze zelf de eigen gezondheld kunnen beinvloeden. Uit deze verschillen is ten dele op te maken dat deze non-respondenten ook al in 1981 een slechtere gezondheld bezaten. $\mathrm{Zij}$ gingen toen al vaker naar de dokter, en gezondheid nam een belangrijkere plaats in hun leven in. 
Tabe 1 6.3 Digcriminant-aralyse op de non-respondenten wegens gezondheidsreden en de respondenten (n is resp. 22 en $882 ; 1981)$

factor: gestandaardiseerde discriminant-coefficient

$\begin{array}{lr}\text { leeftijd } & .58 \\ \text { social-economische status } & -.43 \\ \text { waarde van gezondheid } & .45 \\ \text { doktergbezoek } & .41 \\ \text { voeg } & -.29 \\ \text { lichaambbeweging }(\mathrm{log}) & -.20 \\ \text { roken } & .20 \\ \text { beinvloeden eigen gezondheid } & -.18\end{array}$

(elgenwarde $=.05$; can.correlatie=.21; p kleiner dan .001)

Wel hadden ze relatief minder klachten. Wellicht dat de klachten die ze hadden ernatiger van aard waren, wardoor ze minder aandecht besteedden aan de minder ernstige klachten.

In tabel $6.4 \mathrm{zi}$ in de gestandaardiseerde discriminant-coefficienten weergegeven van de vergelijking tussen de non-respondenten welke niet meer berelkbaar waren, en de respondenten.

Utt deze analyse blijkt dat degenen die niet berelkbaar waren zich niet allaen onderscheiden van de respondenten, doordat ze een lagere sociasleconomische status hebben en jonger zijn, maar ook omdat ze minder van menling zijn dat ze gebeurtenisaen zelf kunnen beheersen (interne beheeralingarientatie). Verder gebruikten ziJ in 1981 iets minder alcohol, maar lets meer medicijnen en waren zij minder vaak gehuwd dan de respondenten.

Geen gegevens zijn opgenomen over de vergelijking tussen de non-respondenten welke weigerden, en de respondenten, aangezien beide groepen niet significant van elkar verschilden (eigenwarde $=.009$; can.correlatie $=$ $.09)$.

Samenvattend kunnen we zeggen dat afwijkingen in de representativiteit van de onderzochte groep het onderzoek, gezien hasr doelstelling, niet nadellg beinvloeden. Of er een response-bias met betrekking tot de onderzoeksvariabelen is opgetreden kan voor de eerste meting niet achterhaald worden. 
Tabe1 6.4 Discriminant analyse op de non-respondenten welke niet bereikbear waren, en de respondenten (n is resp. 125 en 882; 1981 ).

factor : gestandaardiseerde discriminent coefficient

$\begin{array}{lr}\text { sociaal-economiache status } & -.64 \\ \text { interne beheersingsorientatie } & -.51 \\ \text { leeftijd } & -.42 \\ \text { alcoholgebruik } & -.25 \\ \text { medicijngebruik(log) } & .23 \\ \text { gehuwd en semenmonend } & -.19\end{array}$

(eigenwaarde=.03; can. correlatie=.16; p kleiner dan .001)

Dit is wel gebeurd voor de uitval bij de tweede meting.

Een weigering om aan het onderzoek mee te doen, verreweg de grootste en belangrijkste groep, bleek geen verband te houden met de onderzochte variabelen. De non-response vanwege gezondheidsreden en vanwege onbereikbarcheid bleek samen te hangen met sociaal-economische status en enkele anderzoeksvariabelen. De eerste groep is echter zo klein dat zijj de resultaten nauwelijks kan beinwloeden. De gestandaardiaeerde discrininantcoefficient van -.51 in de tweede groep betekent dat de interne beheersingsorientatie de non-response beinvloed heeft, zodat in de uiteindelijke response wat meer intern-georlenteerden zullen zitten. Zou de interne beheersingsorientatie geen invloed hebben gehad ap de respons, dan zou, viltgaende van de mediaan, $48 \%$ van de onderzochte groep ( $=423$ personen) als "niet-intern georienteerd" omschreven zijn. Door een selectie blas binnen een subgroep vinden we echter "Blechts" 415 niet-Intern georienteerden. Dit is de belengrijkate vertekening die in de onderzochte populatle kon worden aangetroffen.

\subsubsection{AFBAKENING VAN HET AANTAL RESPONDENTEN}

Yoor deze studie is het panel gekozen als de uiteindelijke onderzoeksgroep. Om twee redenen is een aantal respondenten uit het panel niet in 
de analyses betrokken. Allereerat zijn de respondenten met een chronische aandoening, warwoor ze regelmatig voor controle naar de dokter moeten, uit de onderzoeksgroep verwijderd. Dit is gebeurd an een tweetal redenen. Allereerst omdat, zoals reeds eerder is aangegeven, het onderzoek gericht 1a op een min of meer gezonde populatie. Personen met een chronische aandoening kunnen julat terwille van hun aandoening "verplicht" geweest zijn zlich gezonder te gaan gedragen, zoals hertpatienten, die na een infarct door de arts dringend werzocht worden te stoppen met roken. In felte is hier geen sprake meer van duidelijke keuzevrijheid. Een andere reden is dat uit enkele proefinterviews bleek det personen met een chronische handicap vask geneigd waren bij de gezondheidsspecifleke beheersingsorientatie-vragenlijst de termen gezondheid en ziekte zeer specifiek in te vullen. namelijk naar hun eigen handicap. Hierdoor zal een verschil in beheeraingaorlentatie niet alleen opgevat kunnen worden als een verschil in opvatting, mar ook als een feiteli.jk verschil tussen handicaps. Bij bepaalde aandoeningen zal men zelf weinig kunnen doen on beter te worden of minder last te hebben, bij andere aandoeningen is die mogelijkheid wel tot op zekere hoogte aanwezig. Een bijkomend voordeel is dat, door de reapondenten met een chronlache aandoening uit het onderzoek te verwijderen, er een homogenere onderzoekspopulatie ontstast. Zoals uit hoofdstuk 4 bleek 1 a de gezondheidstoestand gerelateerd aan de beheersingsorientatie, zodat deze mogelijk als intervenierende factor kan werken bij de relaties tussen de beheersingsorientatie en het gezondheids- en ziektegedrag. Het aantal reapondenten met een chronische aandoening bedragit 136 . Tenelatte is om een geheel andere reden een verdere reductie aangebracht. Zoals in hoofdstuk 7 beschreven zal worden is bij 36 respondenten sprake van een antwoordtendentie bij de beheersingaorientatie-vragenlijst. Deze reapondenten zijn ook verwijderd, wardoor het uiteindelijke aantal gebruikte respondenten op 710 komt.

\subsection{DE VARIIABELEN}

Zoals in paragraaf 6.2 is aangegeven, zijn van de respondenten gegevens bekend ult 1981 en uit 1983. Aangezien in deze studie gebruik genaakt wordt van een gezondheidsspecifieke beheersingsorientatie, en deze alleen in 19.83 gemeten is, zal voornemel1jk gebruik gemakt worden van de gegevens uit 1983. In enkele gevallen wordt gebruik gemarkt van de gegevens van 1981. Hierblj gaat het om gezondheidsopvattingen, welke niet in 1983 gemétien zijn.

De gebruikte variabelen zijn te ordenen naar de volgende categorieen:

- de gezondheidsspecifieke beheersingsorientatie

- achtergrondgegevens

- gezondheidstoestand 
- (gezondheids)opvattingen

- gezondheldagedrag

- ziektegedrag en

- de attitude, subjectieve norm en intentie ten aanzien van roken en alcoholgebruik

De operationalisatie van de gezondheidsspecifieke beheersingsorientatle zal uitvoerig in hoofdstuk 7 an bod komen.

De andere variabelen zullen hier besproken worden, waarbij we voor de onderlinge samenhang en vergelijkingen met andere onderzoeken werwijzen naar de correlatie-matrix in bijlage 7 en de beide onderzoeksrapporten (Adriaanse e.a., 1981; Halfens e.a., 1984).

\subsubsection{DEMOGRAF ISCHE KENMERKEN}

In de literatuur worden als relevante demografische kenmerken voor de beheersingoorientatie genoend sexe, leeftijd en sociaal-economigche status. Hieraan hebben we burgerlijke staat toegevoegd.

De socisal-economische status is samengesteld op basis van het beroep en functie, thet antal personen waraan leiding wordt gegeven, de opleiding en de leeftijd van de koatwinner.

De statistische gegevens van de demografiache kenmerken staan vermeld in tabel 6.5 .

Tabel 6.5 Statistische gegevens demografische kenmerken $(n=710 ; 1983)$.

empirische gemiddelde/ standaard scheef- betekenis spreiding percentage deviatie heid

perc.

$\begin{array}{lccccc}\begin{array}{l}\text { vrouwen } \\ \text { leeftijd }\end{array} & - & 52.7 & - & - & - \\ \begin{array}{l}\text { gociaal- } \\ \text { econom. } \\ \text { gtatus }\end{array} & 1-5 & 42.5 & 12.5 & .45 & \text { agnt. jaren } \\ & & 2.9 & 1.1 & .46 & \text { laag-hoog }\end{array}$

percentage

gehuwden/

samenwo-

nenden 


\subsubsection{SUB JECIIEVE GEZONDHE IDSTOESTAND}

Op een drietal wijzen is de subjectieve gezondheidstoestand gemeten. Allereerat io gevraagd in hoeverre men de eigen gezondheid goed dan wel slecht beoordeelt. Verder zijn een tweetal $11 j$ sten met gezondheidaklachten aan de respondenten voorgelegd. De eerste lijst 18 de vragenlijst onderzoek ervaren gezondheld, kortweg de VDEG genoemd (Dirken, 1967).

Deze 11.jst onvat 49 lichamelijke klachten met de vraag of men hier de latate tijd weleeng last van heeft gehad. De interne betrouwbaarheid volgens Cronbach"s alpha bedraagt .81. Met de tweede $11 \mathrm{jst}$ van $40 \mathrm{licha-}$ melljke klachten is opecifleker gevraagd naar het aanwezig zijn van klachten binnen een afgebakende tijdsperiode, namelijk de afgelopen zeven dagen (Joosten en Philipsen, 1978). Door middel van sommatie van de klachten is ook hiervan een klachtenscore semengesteld. De interne betrouwbaarheid bedraagt .73. Dpgenerkt moet worden dat deze lijist slechts aan 489 respondenten is voorgelegd, omdat tijjens het veldwerk bleek dat het interview langer duurde den op basis van de proefinterviews verwacht. was. Deze lijst is toen bij de resterende interviews om begrotingstechniache en humanitaire reden niet meer afgenomen. De lijst is samengesteld teneinde tot enige overeenstemming te komen met betrekking tot de ernst van de klachten. Aan een 35-tal deskundigen, met name huisartsen zijn de klachten voorgelegd met de vraag in welke mate $(0=$ niet noodzakelijk, 3ezeker noodzakeli.jk) een huisarts tijdens een eerste consult de klacht. allereerst moet beschouwen als een uiting van een mogelijk ernstige somatische andoening. Op basis van de gemiddelde scores is per klacht een ernst-score te bepalen. De respondenten, die een of meer klachten op deze lijsat noemden, is gevraagd aen te geven welke de hoofdklacht was. Voor deze hoofdklacht ia de ernat van de klacht bepaald door de gemiddelde acore van de 35 deakundigen te nemen. Tevens is an de regpondenten zelf gevraagd aan te geven hoeveel aaneengesloten dagen ze last hadden van deze kliacht.

In tabel 6.6. zijn de statistische gegevens van deze variabelen weergegeven.

\section{3 .3 OPVATTINGEN}

\subsubsection{DE ALGEMENE BEHEERSINGSORIENTATIE}

In hoofdstuk 3 is reeds ingegaan op de door ons in 1981 gebruikte algemene beheersingsorientatie-lijat (zie ook bijlage 2). In tabel 6.8 zijn de statistische gegevens, berekend over de onderzoekspopulatie, weergegeven. 
Tabe1 6.6 Statistische gegevens subjectleve gezondheidstoestand $(n=710 ; 1983)$.

empirische gemiddelde standaard scheefheid betekenis spreiding deviatie

\begin{tabular}{|c|c|c|c|c|c|}
\hline eigen gezondh. & $2-5$ & 4.1 & .6 & -.27 & $\begin{array}{l}\text { slecht-zer } \\
\text { goed }\end{array}$ \\
\hline Voegl & $0-36$ & 8.0 & 5.8 & 1.1 & $\begin{array}{l}\text { aantal } \\
\text { klachten }\end{array}$ \\
\hline $\begin{array}{l}\text { klachten af- } \\
\text { gelopen week (1) }\end{array}$ & $0-12$ & $1 . B$ & 2.4 & 1.9 & aentel \\
\hline ernst klacht (2) & $0.63-2.06$ & 1.1 & .29 & 1.1 & $\begin{array}{l}\text { mate van } \\
\text { ernet }\end{array}$ \\
\hline duur klacht (2) & $1-98$ & 17.5 & 31.7 & 2.0 & $\begin{array}{l}\text { aantal } \\
\text { dagen }\end{array}$ \\
\hline
\end{tabular}

(1) $n=489$

(2) $n=297$

\subsubsection{GEZONDHEIDSOPVATTINGEN}

Tijdens de interviews in 1981 en 1983 zijn verschillende opvattingen ontrent gezondheid gemeten. Een aental zijn voor dit onderzoek relevent. Allereerst is voor het model van Rotter van belang de warde die men hecht aan gezondheid. Hiervoor is aan de respondenten de vraag voorgelegd in hoeverre men een aantal nader genoemde zaken (zie tabel 6.7) belangrijker (1), even belangrijk (2) of minder belangrijk (3) dan gezondheid vindt. Uit tabel 6.7 blijkt dat er meer personen zijin die het geztn, vrede en/of vrijheid belangrijker vinden dan personen die gezondheid belangrijker vinden. 
Tabe1 6.7 Zaken die men belangrijker, of minder belangrijk dan gezondheid windt ( $n=710 ; 1983$; in percentages en geordend naer belangrijkheid).

belangrijker minder belangrijk

$\begin{array}{lrr}\text { gezin } & 15 & 5 \\ \text { vrede } & 18 & 9 \\ \text { vrijheid } & 14 & 12 \\ \text { vriendschap } & 10 & 26 \\ \text { huisvesting } & 6 & 29 \\ \text { werk } & 7 & 36 \\ \text { sociale zekerheid } & 7 & 32 \\ \text { sport } & 3 & 64 \\ \text { geloof } & 9 & 61 \\ \text { geld } & 2 & 75\end{array}$

Door middel van sommatie van deze antwoorden is een schaal samengesteld. Hierbij is het antwoord op de afweging tussen gezondheid en geloof niet meegenomen, ondat deze laag correleerde met de totaalscore van de schaal. De interne consistentie bedraagt zodoende .78. Aangezien dezelfde vraag ook in 1981 an de respondenten is voorgelegd, is van deze schaal ook de teat-herteat betrouwbarheid berekend. Deze bleek .27 te bedragen. De warde die men hecht aan gezondheid is dus over een periode van 2 jaar niet erg atabiel.

Behalve met een gezondheidsspecifleke beheersingsorientatie is ook op andere wijzen gevraagd naar de mate warin men de eigen gezondheid kon beinvloeden. Zo is aan de reapondenten gevraagd aan te geven wie volgens hen de meeste invloed heeft op hun gezondheid, wie vervolgens en zo verder. Zodoende is voor elke persoon of instantie een rangorde verkregen van B (meeste invloed) tat $\mathbb{1}$ (minate invloed). Van deze 1 ijat zal alleen de rangorde gebruikt worden die men zichzelf en de arts heeft toegekend. Behalve naar de positie die ze zelf innemen in de lijst met personen en instanties is ook gevraegd naar de mate warin men de elgen gezondheid kan belnvloeden. Tot alot is in 1983 gevraagd in welke mate men zich verantwoordelljk acht voor de eigen gezondheid.

In deze studle maken we ook gebrulk van gezondheidsopvattingen welke in 1981 gemeten zijn met behulp van een lijst met uitspraken over de medische wetenschap. Deze lijst is ontleend aan Cassee (1973). Van deze lijat is een tweetal schalen middels sonscores geconstrueerd. In bijlage 4 staan de items en de daarap toegepaste factor-analyses weergegeven. De 
rabel 6.8 Statiatische gegevens (gezondheids)opvattingen ( $n=710$, 1981 en 1983).

empirische gemid- standaard scheefheid betekenis spreiding delde deviatie

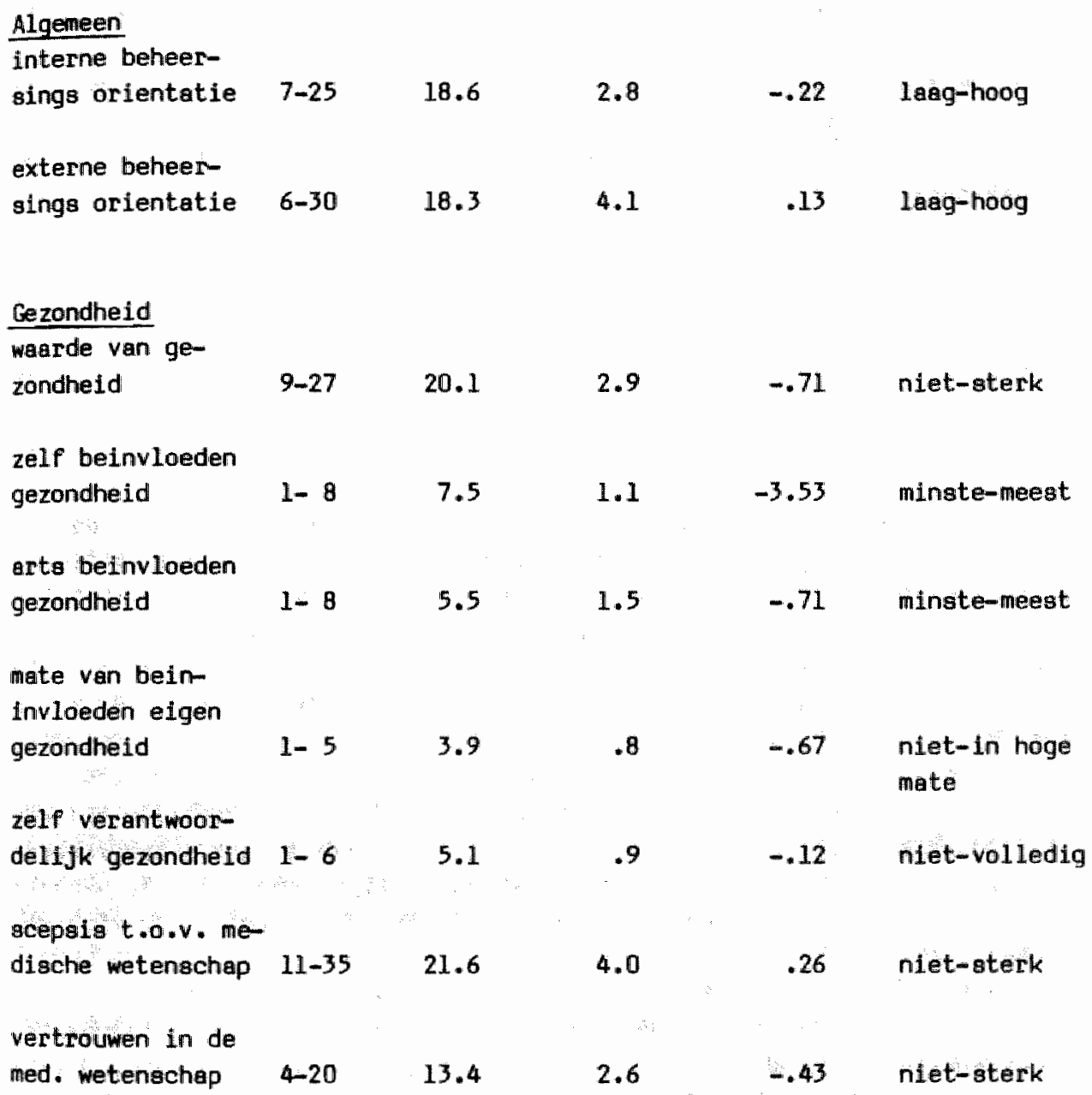


eerate schel is "acepsis ten opzichte van de medische wetenschap" genoend: en bevat ultapraken als "doktoren beloven meer dan ze feitelijk kunnen ooen" en "artaen gewen lang niet altijd het juiate advies". Hoewel deze Bchael naum amenhangt met de tweede achal, vertrouwen in de medische wetenschap, worden beide on inhoudelijke reden als aparte schalen gebruikt. De ultapraken welke de achael "vertrouwen in de medische wetenschap" vormen, hebben namelijk niet zozeer het medisch handelen als wel de gezondheld als onderwerp, wardoor deze uitspraken opgevat kunnen worden als een machtige anderen beheersingsorientatie omtrent de gezondheid. Uitspraken behorende tot deze achaal zijn "als je maar precies doet wat de dokter zegt, heb je de grootste kans on beter te worden" en "In een ziekenhuis weten ze precies wat goed voor je $\mathrm{is}^{\prime \prime}$. De interne betrouwbaarheid van beide ochalen is respectievelijk .78 (scepsis) en .72 (vertrouwen).

In tabel $6.8 \mathrm{zijn}$ de statistiache gegevens van de gezondheidsopvattingen weergegeven.

\section{3 .4 ZIEKTEGEDRAG}

\subsubsection{INTENTIE TOT ZIEKTEGEDRAG}

Aan de respondenten is niet alleen naar het feitelijk ziektegedrag gevraagd, maar aok naar de intentie tot ziektegedrag. Om deze intentie te meten is een 11jat met specifieke klachten gebruikt, welke door Mootz (1981) naar aanleiding van een soortgelijke 1ijat van Cassee (1973) ontwikkeld is. De klachten zijn in deze lijst gespecificeerd zowel naar de aard als naar de duur (zie bijjlage 5). Aan de reapondenten is gevraagd wat men bij elk van de 18 klachten zou doen: er geen aandacht aan besteden, afwachten of het vanzelf over gaat, medicijnen gebruiken, de valgende dag naar thet opreekuur van de dokter gaan, de dokter zo snel mogelijk bellen, of iets anders. Door sommatie ven het antal antwoorden per antwoordcategorie, waarbij "geen aandacht" en "afwachten" zijn samengevoegd, evenals "de volgende dag naar de dokter gaan" en "de dokter bellen", zijn vier variabelen samengesteld.

In tabel $6.9 \mathrm{zijn}$ de atatistiache gegevens hierven weergegeven.

Aangezien het merendeel van de respondenten geen enkele maal als antwoord "ieta anders" genoend heeft, is deze variabele erg scheef verdeeld. Door wan de variabele de logaritme te nemen is deze enigazins verbeterd (zle tabel 6.9). De interne betrouwbaarheld van de schalen is reapectievelijk .77 (afwachten), .54 (medicijngebruik), .77 (dokterabezoek) en .86 (arders). Met uitzondering van de schaal medicljngebruik zijin de interne conslatenties van deze schalen dus goed. 
Tabe1 6.9 Statistische gegevens intentie tot ziektegedrag $(n=710 ; 1983)$.

empirische genid- stendeard scheefheid betekenis spreiding delde deviatie

\begin{tabular}{|c|c|c|c|c|c|}
\hline afwachten & $0-18$ & 11.0 & 3.6 & -.40 & $0-18 \times$ genoemd \\
\hline \multicolumn{6}{|l|}{ medicijn- } \\
\hline gebruik & $0-7$ & 1.1 & 1.3 & 1.32 & $0-7 \times$ genoend \\
\hline \multicolumn{6}{|l|}{ dokters- } \\
\hline bezoek & $0-18$ & 5.5 & 3.3 & .60 & $0-18 \times$ genoend \\
\hline anders & $0-18$ & .4 & 1.5 & 6.66 & $0-18 \times$ genoend \\
\hline anders ( 109 ) & $0-1.3$ & .1 & .2 & 2.69 & logaritme $(x+1)$ \\
\hline
\end{tabular}

\subsubsection{GERAPPORTEERD ZIEKTEGEDRAG}

Om een vergelijking te kunnen maken tussen de intentie en het feitelijk (gerapporteerde) gedrag, is aan de respondenten die in de week voorafgaand aan het interview, gezondheidaklachten hebben gehad, gevraagd aan te geven wat ze voor deze klacht of - indien men meer klachten heeft gehad - voor de belangrijkate klacht gedean hebben. Hierbij zijn wrijwel dezelfide antwoordcategorieen angehouden als bij de intentie tot ziektegedrag. Het gebruik van medicijnen is echter gesplitat in voorgeschreven en niet-voorgeschreven medicijnen.

Een probleem is dat men meestal meer zaken onderneent in geval van een klacht. Bijvoorbeeld eerst afwachten, vervolgens een pijnstiller gebruiken en tot slot naar de dakter gaan. Vandaar dat de respondenten de mogelijkheld hadden on meer antwoorden te geven. On van deze antwoorden een hanteerbare variabele te maken, zijn de antwoorden geordend naar de mate van belangrijkheid, waarbij de arts raadplegen als het belangrijkste is opgevat, vervolgens de voorgeschreven medicijnen, de niet-voorgeschreven medicijnen, lets anders doen en tot slot afwachten als de minst belengrijke categorie. Vervolgens zijn de respondenten, die klechten hebben gehad, op basis van hun antwoorden in die categorie geplaatst, welke in volgorde van belangrijkheid de hoogate positie inneemt. Zo is degene die 
als antwoorden gegeven heeft "afwachten of het vanzelf over gaat", "iets anders" en "niet-voorgeschreven medicijnen", geplaatst in de categorie "niet-woorgeschreven medicijnen", arngezien deze de hoogate positie in deze rangorde inneemt.

In tabel 6.10 is het percentage respondenten per categorie weergegeven.

Tabel 6.10 Frequentieverdeling gerapporteerd ziektegedrag $(n=297 ; 1983)$.

absolute aantallen percentage

$\begin{array}{lll}\text { afwachten } & 105 & 35.3\end{array}$

niet-voorgeachreven $\quad 29 \quad 9.8$

medicijnen

voorgeschreven

22

7.4

medicijngebruik

89

30.0

dokterabezoek

52

17.5

anders

totaal

297

100.0

\section{3 .5 GEZONDHEIDSGERAG}

\subsubsection{ALGEMENE LEEFWIJZE}

In hoofdatuk 5 hebben we reeds opgemerkt dat verschillende pogingen on een index voor gezondheidagedragingen te construecen feitelijk mislukt zijn. Aangezien een dergelijke index van belang is voor ons onderzoek, is in de vragenlijst, naast enkele specifieke gezondheldagedragingen die uitgebreider aan de orde kwamen, een $1 \mathrm{ij}$ st met 15 gezondheidsgedragingen opgenomen. Met behulp van factor-analyse en interne betrouwbaarheidsanalyse is gepoogd een schaal te construeren. Aangezilen de interne betrouwbaarheidscoefficient op geen enkele manier boven de 20 uitkwam, hebben 
we hiervan afgezien. Nu is het gebruikelijk in de 1iteratuur (0.8. Gottlieb en Green, 1984; Berkman en 5yme, 1979; Belloc en Breslow, 1972) ondanke de lage interne betrouwbearheld de gezondheidogedragling toch te sommeren. Als legltimatle hiervoor geldt dat in deze onderzoeken gekeken wordt naar de relatie gezondheidstoestand en gezondheldsgedrag. Hoewel mensen zelf gezondheldsgedragingen niet als soortgelijk percipleren hebben deze wel alle een effect op de gezondheidstoestand. Door de gezondheidsgedragingen te sommeren, wordt in feite dit effect gesommeerd. Aangezien in dit onderzoek niet de relatie gezondheidsgedrag en gezondheidgtoestand centraal staat, vervalt deze legitimatie an de gedragingen te sommeren. Dit betekent concreet dat vragatelling vier - hangt de beheersingsorientatie samen met een algemene mast voor gezondheidsgedrag - feltelijk niet bestudeerd kan worden.

Wel zijjn nog op twee andere manieren aspecten van de algemene leefwijze gemeten. Aan de respondenten is gevraagd aan te geven in welke mate ze de eigen leefwijze gezond vinden.

Verder zijn in 1981 een aantal open vragen an de respondenten voorgelegd omtrent zaken die men doet of laat voor de eigen gezondheid. Door uitsluitend het aantal antwoorden te sommeren is een schaal verkregen met een interne consistentie van .82, welke we "bewust zijn eigen leefwijze" genaemd hebben (zie ook tabel 6.11).

Tabel 6.11 Statiatigche gegevens algemene leefwijze $(n=710$; 1981 en 1983).

empirische gemid- standaard scheef- betekenis spreiding delde deviatie heid

$\begin{array}{llllll}\begin{array}{l}\text { beoordeling } \\ \text { elgen leefwijze }\end{array} & 2-7 & 5.6 & .9 & 1.26 & \begin{array}{l}\text { ongezond/ } \\ \text { zeer onge- }\end{array} \\ \text { als gezond } & & & & & \\ \begin{array}{l}\text { bewut zijn } \\ \text { eigen leefwijze }\end{array} & 0-15 & 4.4 & 3.1 & .50 & \begin{array}{l}\text { arntal ant- } \\ \text { den }\end{array}\end{array}$

\subsubsection{ROOKGEWDONTEN}

Nasst de vraag of men al of niet wel eens rookt, is aan degenen die zeiden niet te roken, gevraagd of ze vroeger gerookt hebben, terwijl aan de- 
genen die wel eens roken is gevraagd hoeveel ze per dag roken. Aangezien van de roker vrijwel ledereen sigaretten rookt, en het niet mogelijk bleek het aantal sigaretten, sigaren en pijpen in een variabele onder te brengen, 18 wat de hoeveelheld betreft alleen het aantal sigaretten van degenen dle slgaretten roken als indlcatie genomen. In tabel 6.12 z 1 jn de gegeveno omtrent de rookgewoonten weergegeven.

Iabe1 6.12 Stat1stische gegevens rookgewoonten $(n=710 ; 1983)$.

empirische gemidd./ standaard scheef- absolute spreiding percent. deviatie heid aantal

percentage

rokers

$-\quad 49.4$

$-\quad-$

351

percentege

ex-rokera

$\begin{array}{r}-\quad 24.9 \\ \hline\end{array}$

- $\quad-$

aantal

aigaretten(1)

$2-75$

16.5

10.7

1.56

percentage

mislukte

stoppoging(2)

34.2

120

(1) $\mathrm{n}=322$

(2) $\mathrm{n}=351$

\section{3 .5 .3 ALCOHOLCONSUMPTIE}

Ten aenzilen van het alcoholgebrulk zijn soortgelijke vragen gesteld als ten banzlen van de rookgewoonten. Allereerst is gevraagd welke alcoholhoudende dranken men wel eena drinkt. Op basis hiervan is een onderscheid gemaakt in wel en niet alcoholgebruikers. Degenen die geen alcohol gebruiken, is gevraagd of men vroeger wel eens alcohol heeft gebrulkt. Degenen die wel alcohol gebrulken is gevraagd per deg over de afgelopen zeven dagen het aantal glazen alcoholhoudende drank op te geven. Aan de 
hand hlervan is de frequentie en het geniddelde antal glazen per dag belde berekend over de zeven dagen - vastgesteld. Tot slot ls nog aan de alcoholgebruikers gevraagd of men het afgelopen jaar een of meerdere pogingen gedaan heeft on definitief te stoppen met het drinken van alcoholhoudende drank.

Tabel 6.13 geeft de statistische gegevens van deze variabelen.

Tabel 6.13 Statistische gegevens alcoholconsumptie ( $n=710,1983)$.

empirische gemidd./ standard scheef- betekenis spreiding percent. deviatie held

percentage

gebruikers

percentage

ex-gebruikers

frequentive van

gebruik

aantal glazen/

keer (2)
$-83.1$

$-6.2$

$0-7$

3.4

2.4

2.0

2.9

$1-12$

1.84

.24

in dagen; alle gebruiker

alleen gebruikers afgelopen 7 dagen

percentage mis-

lukte stop-

poging (1)

3.9

(1) $\mathrm{n}=590$

(2) $n=527$

\section{3 .5 .4 LICHAAMSBEWEGING}

Ten aanzien van lichaamsbeweging is allereerst nagegaan wie wel en wie niet aan lichaamsbeweging doen. Vervolgens is an degenen die niet aan lichaamsbeweging doen, gevraagd of ze hieraan vroeger wel deden, terwijl 
aan degenen die wel lets aen lichaamabeweging doen, gevraagd is hoeveel uur men hleraan gemiddeld per week besteedt. Tot slot is an alle respondenten gevrasgd of ze wan plan zijn geweest meer aan lichaamabeweging te gaan doen.

Uit tabel 6.14 blijkt dat het antal uren scheef verdeeld is: Vandaar dat ook hierwan de logaritme is berekend.

Tabel 6.14 Statistische gegewens lichaamsbeweging ( $n=710$; 1983).

empiriache genidd./ stand. scheefh. betekenis spreiding percent. deviatie

percentage

bewegers

percentage

ex-bewegers

aantel uren

beweging(1)

aantal uren

beweging

(log) (1)

intentie tot $1-3$

bewegen
51.3

30.7

3.7

3.9

4.6

hele uren/

week

$.80 \quad$ logaritme

$(x+1)$

(1) alleen bewegers $(n=364)$

6.3.6 DE ATTITUDE, SUBJECTIEVE NORM EN INTENTIE TEN AANZIEN VAN ROKEN EN ALCOHOL GEBRUIK

In hoofdstuk 5 is het model wan Fishbein en Ajzen reeds beschreven. Gesteld is dat de intentie de beste voorspeller is van het gedrag, terwijl de Intentle op haar beurt het beste voorspeld kan worden door de attitude en de subjectieve norm ten opzichte van dat gedrag (zie fig. 5.1). 
On de hierna volgende redenen zijn de attitude, de subjectleve narm en de intentle niet alleen ten aenzien van roken (of alcoholgebruik), maar ook ten aanzien van niet-roken (of geen alcoholgebrulk) geneten.

Eerder is reeds aangegeven dat er sprake moet zijn van nuveau-overeenkonst tussen variabelen. W1 men redelijke samenhangen verwachten dan moeten de variabelen van eenzelfde niveau zijn. Dit betekent dat indien roken het betreffende gedrag is, de intentle, de attitude en de subjectieve norm gemeten moeten worden ten aanzien van roken. Nu doet zich met gedragingen als roken en alcohol drinken het probleem voor dat deze verachillende gedragoalternatieven kennen, bijvoorbeeld niet roken minder roken, of meer roken. Aan de hand van een klein ondezoekje bij rooksters omtrent het stoppen met roken laat fishbein (1982) de consequenties hiervan zilen. De intentie tot stoppen met roken bleek niet gerelateerd te zijn aan het feitelijke gedrag. Door aan de respondenten ook de intentie ten aanzien van de andere gedragamogelijkheden te vragen, werd duidelijk dat rooksters welke van plan waren te stoppen met roken, maar dit uiteindelijk niet deden, een hogere intentie hadden om hun rookgedrag te cont1nueren of alleen te minderen, dan om te stoppen. Verschilscores tussen de gedragsalternatieven bleken dus goede indicataren voor het feitelijk gedrag te zij.jn. Dok uit ander onderzoek blijkt dat verschilscores tot betere voorspellingen van het uiteindelijke gedrag leiden, dan de intentie ten sanzien van slechts een gedragsalternatief (Marsh en Mattheson, 1983). In feite wordt door de intentie ten opzichte van meerdere gedragoalternatieven te meten, de betrouwbaarheid van de intentie verhoogd. Hoewel bij Fishbein (1982) het stoppen met roken centraal stond, geldt dit ook voor het roken zelf. Degene die sinds enkele maanden niet meer rookt, maar wel af en toe een of meer trekjes neemt bij vrienden, zal het volstrekt oneens zijn met de stelling dat, hij of $z i j$ de komende maand zal roken. Op de uitapraak dat men de komende maand niet zal roken, zal echter warschijnlijk minder stellig geantwoord worden. Het antwoord op de laatste uitapraak zal dan ook meer in overeensteming zijn met de attituden ontrent het nilet roken.

Een endere reden warom verschilscores van belang $z i j n$, heeft betrekking op het meten wan de waarachijnlijkheden. Indien een individu van een bepaald gedrag, zoals roken, een bepaelde consequentle verwacht, bijvoorbeeld longkanker, sluit dit niet uit, dat hij of zij dezelfde conaequentie verwacht bij het niet uitvoeren van het gedrag, bijwoorbeeld amdat in zijn of haar familie al veel personen jong gestorven zijn aan longkanker, ongeacht of deze rookten of niet. Bij de waarschijnliskheden gaat het er steeds om dat een individu een bepaalde consequentie toeschrijft aan een bepaeld gedrag. Door de persoon de mogelijkheid te bieden de consequentie ten aanien van beide gedragsalternatieven aan te geven, kan een betere afweging tot stand komen ten aanzien van het werkelijk verwachte effect van het gedrag.

Vandaar dat de betreffende variabelen gemeten zijn voor zowel het roken (of alcohol drinken) en het niet roken (of geen alcohol drinken). 
Hoewel Fishein (1982) gebruik makt van verschilacores tussen beide gedragalternatieven, hebben wij deze, na hercoderen van het niet roken (en het geen alcohol drinken) in de richting van het roken (en alcohol drinken), gesomineerd. Beide methoden komen feltelijk op hetzelfde neer - een negatleve varlabele 1 namelijk dezelfde als een gehercodeerde variabele plus een bepaalde warde -, maar sommering bledt het voordeel dat de interne betrouwbarheid van de aanengeatelde variabelen berekend kan wor den.

Alvoreng in te gan op de statiatische gegevens omtrent de attitude, de subjectieve norm en de intentie zullen we eerst aangeven op welke wijze deze gemeten zijn.

\section{Intentie}

De intentle is gemeten met behulp van de uitspraken: "Ik zal de komende meand roken (niet roken, alcohol drinken, geen alcohol drinken)". Hierbij is een zevenpuntssicheal als antwoordscharl gebruikt ( 1 = helemael mee oneens, 7 = helemaal mee eens).

\section{Attitude}

Voor de attitude zijn per gedragamogelijkheid drie uitapraken aan de respondenten voorgelegd. Met behulp van zevenpuntschalen is gevraagd of men het betreffende gedrag heel goed ( 7 ) dan wel theel slecht (1), en zeer prettig (7) dan wel zeer onprettig (1) en zeer noodzakelijk (7) dan wel helemeal niet noodzakelijk (1) acht.

\section{Subjectieve norm}

De subjectieve norm is per gedraganogelijkheid gemeten door aan de regpondenten te vragen in hoeverre men het eens is met de uitspraak "de mesete mensen die belangrijk zil.jn voor mij, vinden dat ik moet roken (nlet roken, alcohol drinken, geen alcohol moet drïnken)".

Vrdlfwel niemand (2\%) bleek het echter eens te zijn met de uitspraak "de meeste mensen die belangri.jk $z 1 j n$ voor mij, vinden dat 1 k 'moet' roken (alcohol drinken)". Hoewel het woord "moet" tussen asnhalingsregels is geplaatst, blijkt deze uitapraak te extreem. In eerste instantie is daarom de uitspraak, "de meeste mensen die belangrijk zijn voor mij, vinden dat ik niet moet roken" als subjectieve norm genomen. We geven echter de voorkeur an een variabele die samengesteld is op basis van meerdere vragen, zoals we dat gedaan hebben bij de Indirecte subjectieve nom. Bovendien to de oamenhing bij beide gedragingen tussen de subjectieve norm en de intentie geringer dan tussen de indirecte subjectieve norm en de intentie. Vandaar dat uiteindelijk de indirecte subjectieve norm als indicatie voor de subjectieve norm is gebruikt.

De indirecte subjectleve norm is samengesteld aan de hand van de normideeen en de insteming. Als normideeen zijn gevraagd of de partner (kinderen, vrienden/kennissen, collega's en de arts) vindt dat de reapondent a. niet moet cokken (geen alcohol moet drinken), b. "moet" roken (alcohol 
'moet' drinken). Voor elk normidee is een zevenpuntg-antwoordscheal $(-3=$ helemeal mee oneens, 3 = helemal mee eens) gebruikt, warbij niet van toepasaing als 0 gecodeerd is. Aangezien zich bij deze nornideeen hetzelfde probleem voordeed als bij de directe subjectieve norm, zljn de antwoorden op de normideeen ontrent het 'moeten' niet gebruikt. De in steming is gemeten doar te vragen hoeveel belang de respondent hecht aan de mening van de partner (kinderen, vrlenden/kennissen, collega's en de arts), als thet om roken gaat. Ook hier is weer aan de hand van een zevenpuntsacheal ( 1 = zeer weinig, $7=$ zeer veel) geantwoord. Vervolgeno zijn de afzonderlijke normideeen vermenigvuldigd met de bijbehorende inatenmingen. Een score rond de nul betekent zodoende dat de mening van de betreffende persoon niet van belang is voor de respondent, tenminste als het on roken of alcohol drinken gaat. De beide extreme scores, zomel de negatieve als de positieve score, geven weer dat de mening van de persoon in kwestie van belang is, en de respondent het respectievelijk eens of aneens is met de uitspraak dat de persoon in kwestie van mening is dat de respondent nilet moet roken (geen elcohol moet drinken). Tot slot zijn de vi.jf productscores gesommeerd.

In tabel 6.15 zijn de schaalgegevens voor de verschillende variabelen ten aanzien van roken weergegeven.

Tabel 6.15 Statistische gegevens van de attitude, de (indirecte) subjectieve normen en de intentie tot roken ( $n$ $=710 ; 1983$ ).

empirische gemid- standaard scheef- alpha aantal spreiding delde deviatie heid items

$\begin{array}{lrccccc}\text { intentie } & 2-14 & 7.1 & 5.1 & .19 & .96^{1} & 2 \\ \begin{array}{l}\text { attitude } \\ \text { Indirecte }\end{array} & -105-14 & 17.3 & 8.0 & .11 & .80 & 6 \\ \begin{array}{l}\text { subjectieve } \\ \text { narm }\end{array} & -16.0 & 29.2 & -.18 & .79 & 5\end{array}$

$(r=.93)$ 
Uit deze tabel blijkt dat alle variabelen nomal verdeeld, en intern conslatent zijon.

Bekljken de geniddelde scores dan valt op dat voor alle variabelen geldt dat het geniddelde in de richting van het niet-roken ligt. Over het algemeen staat men negatief ten opzichte van roken. Men heeft minder de intentie on te roken, terwij men ook een negatievere attitude en subjectleve norm ten aanzien van roken heeft.

Opgemerkt kan nog worden dat in tegenstelling tot onze verwachting de intentie tot roken blijkbaar nauwelljks verschilt van de intentie tot nietroken $(\mathbf{r}=.93)$. Dit moet warschijnlijk grotendeels toegeschreven worden an het felt dat $z$ llch onder de respondenten zowel rokers als niet-rokers bevinden.

De statistische gegevens van de variabelen voor het al of niet drinken wan alcohol, $z i j n$ weergegeven in tabe1 6.16. Opgemerkt moet worden dat deze variabelen bij slechts een gedeelte van de respondenten zijn gemeten, namelijk bij 481. Tijdens het veldwerk bleek de wragenlijst namelijk langer dan vijf kwartier te duren, hetgeen on budgettair-technische redemen ertoe heeft geleid dat onder andere deze vragen bij de resterende respondenten niet meer zijn gesteld.

U1t tabel 6.16 blijkt dat de interne betrouwbarheid van de variabelen goed is. De attitude blijkt wel enigszins scheef verdeeld te zijn. Deze acheefheid is echter niet zodanig dat een transformatie van de variabelen noodzakelijk is (Tabachnick en Fidel1, 1983).

Tabel 6.16 Statistische gegevens van de attitude, de (indirecte) subjectieve normen en de intentie tot alcoholgebruik $(n=481 ; 1983)$.

empirische gerid- standaard scheef- alpha aantal sprefiding delde deviatie heid itens

$\begin{array}{lcccccc}\text { Intentie } & 2-14 & 9.5 & 3.9 & -.77 & .94 & 2 \\ \begin{array}{l}\text { attitude } \\ \text { indirecte }\end{array} & -9-37 & 23.0 & 6.1 & -1.11 & .83 & 6 \\ \begin{array}{l}\text { indjectieve } \\ \text { norm }\end{array} & & 6.5 & 30.3 & -.24 & .82 & 5\end{array}$


Uit tabel 6.16 blijkt verder dat alle gemiddelden wijzen in de richting van alcahol drinken. Met andere woorden, aver het algemeen heeft men de intentie an de komende maand alcohol te drinken, heeft men een positieve attitude ten opzicht van alcohol drinken, en zijn, volgens de respondenten, anderen niet van mening dat men geen alcohol "moet" drinken.

\subsection{SAMENVATTING}

In dit hoofdstuk is de opzet van het onderzoek besproken. Aangegeven is dat het onderzoek een onderdeel vormt van een panelonderzoek onder de $\mathrm{Ne}$ derlandse bevolking. In dit panelonderzoek, waarvoor zowel in 1981 ls in 1983 een meting is verricht, ls gebruik geneakt van een gestandaardiseerde vragenlijat.

Uitvoerig is ingegaan op de representativiteit en de door de non-response veroorzaakte response van het gebruikte panel. De belangrijkate vertekening van de onderzoekspopulatie bleek de daling van het aantal nilet-Interr-georienteerden van 423 tot 415 te zijn.

Uit het panel zijn de respondenten met een chronische aandaening, waarvoor ze onder behandeling zijn, voor dit onderzoek verwijderd. Hetzelfde geldt voor enkele respondenten bij wie een antwoordtendentie op de beheersingsorientatle-vragenlijst werd aangetroffen. lot slot zijn in dit hoofdstuk de variabelen beschreven.

De operationalisering van de beheersingsorientatie wordt in het volgende hoofdatuk besproken. 
In dit hoofdstuk wordt het meetinatrument, waarmee de beheersingsorientathe is geoperationallseerd, besproken. Allereerst wordt ingegaan op de wye warop het instrument tot stand is gekomen. Daiarna komen de interne betrouwbarideid en statistische gegevens van de, op basis van het meetinstrument, geconstrueerde schalen an de orde. Vervolgens wordt, teneinde inzicht te krijgen in de soortgenoot validiteit, nagegaan in welke mate de schalen samenhangen met soortgelijke (gezondheids)opvattingen. Tot slot wordt nagegaan of de schalen gerelateerd zijn aan de demografische kenmerken en aan de subjectieve gezondheidstoestand.

\subsection{HET MEETINSTRLIMENT}

Als operationaligatie van de beheersingaorientatie is gekozen voor de door Wallstion e.a. (1978a) geconstrueerde 1ijat.

In hoofdstuk 3 is reeds uitvoerig ingegaan op de wijze warop de beheergingsorientatie geneten dient te worden. Gesteld is dat een meetinstrument dat specifiek op een bekrachtigingsgebied is gericht, de voorkeur verdient boven een algemeen meetinstrument. Verder is gesteld dat voor elke (zinvolle) beheersende instantie een aparte schaal geconstrueerd moet worden en dat het zinvol kan zijn een onderacheid te maken tussen positieve en negatieve bekrachtigingen.

Zoale we gezien hebben voldoet de door Wallston e.A. (1978a) ontwikkelde Multi-dimenglonal Health Locus of Control Scale (MHLC) aan deze eisen. Het meetinstrument is specifiek gericht op gezondheid en ziekte, wrarbij een onderscheid gemaakt is in drie beheergende ingtanties, te weten de persoon zelf, machtige anderen en kans of geluk. Voor elke beheersende instantie is een aparte schal ontwikkeld van zes uitspraken met elk een zeo-punts Likert-antwoord-schal. Hoewel er zowel positieve als negatieve ultopraken in voorkomen blijken deze echter geen afzonderlijke schalen te vormen (Wallston e.a., 1978a). Verder zi.jn alle uitspraken in de ik-vorm gesteld. In hoofdatuk $3 \mathrm{zljn}$ we verder ingegaan op de betrouwbaarheid van deze $11 j$ gt, terwijl in hoofdatuk 4 enkele studies met deze lijst zijn gepresenteerd.

Een Nederlandse vertaling van deze lijst is gemaakt door Burink-Withaar, Jansen, Jonkers, en Pruyn (vlgs. Jonkers e.a., 1981). Factor-analyse leidde tot de 3 verwachte factoren, namelijk een interne, een machtige andere en een kans-beheersingsorientatie. Hoewel alle vitspraken de hoogste lading hadden op de voorspelde factor, bleken een aantal uitspra- 
ken een relatief lage lading of lage communaliteit te hebben.

Hede op basis hiervan en op basis van enkele proefinterviews ls deze lijst door ons enigszins angepast. De belangrijkste aanpassing heeft. plaatsgevonden bijj twee uitspraken wit de machtige anderen schasi. Het betrof de uitspraken "Mijn gezin heeft er veel mee te maken dat Ik zlek word of gezond blijf" en "Als ik van een zlekte heratel, komt dat meestal doordat andere mensen (b.W. artsen, verpleegkundigen, familie, vrienden) goed voor me hebben gezorgd". Aangezien in de vier andere uitapraken van deze achaal alleen de arts als beheersende persoon genoend wordt, zijn, on een eenduidige beheersende instantie te verkrijgen, de uitspraken als volgt veranderd: "Artsen hebben er veel invloed op of ik gezond blijf of niet" en "Als ik van een ziekte herstel, heb ik dit toch vooral te danken aan mifn arts". Verdere aanpassingen hebben vooral betrekking gehad op de formulering en het woordgebruik. Zo is de uitspraak "Als het zo voorbestemd is, blijf ik gezond", veranderd in "Of ik gezond blijf is een kwestlie van toevallige gebeurtenissen".

In tabel $7.1 \mathrm{zijn}$ de uiteindelijk gebruikte uitspraken in de meting van 1983 weergegeven. De uitapraken zijn hierbij geordend per achaal, warbij het cijfer verwijot naar de oorspronkelijke positie van de uitspraak in de 1 ijjot.

Aangezien Alleyn (1983) met de door Burink-Withaar e.a. vertaalde lijat vond dat er bij $10 \%$ van de respondenten uit een onderzoek naar borstkanker (zie o.a. Jonkers e.a., 1981) vermoedelijk sprake was van antwoordtendenties, hebben we allereerst op eventuele antwoordtendenties gecontroleerd. Van de 746 respondenten bleken er 36 (5\%) een of meer malen op zes achtereenvolgende uitspraken hetzelfde antwoord gegeven te hebben. In tegenstelling tot hetgeen Alleyn (1983) vond, nam deze tendentie niet toe naarmate de uitspraken meer ean het eind van de 1 i.jst voorkwamen. Hoewel het theoretisch te verdedigen valt dat een respondent op zes achtereenvolgende uitapraken eenzelf de antwoord geeft, zeker alo het de antwoorden "enigszins mee eens" en "enigszins mee oneens" betreft, is hier vermoedeIIjk aprake van een antwoordtendentie. Vandaar dat we deze reopondenten niet In de verdere analyses gebruikt hebben. Een vergelljking van deze groep met de resterende respondenten op de variabelen sexe, leeftifd, aociar-economische atatus, burgerlijke staat, beinvloeden elgen gezondheid, doktersbezoek, aantal gezondheidsklachten, wel of niet roken, drinken van alcohol, en lets aan lichaamsbeweging doen, leert dat beide groepen op deze kenmerken niet significant wan elkaar verschilien.

In tabel $7.1 \mathrm{zijn}$ de antwoorden van de resterende 710 respondenten op de uitspraken van de drie schalen weergegeven.

Principale factoren-analyse (Nie, e.a., 1975) op deze 1ijst gaf voor de eerste drie factoren de volgende eigenwaerden: $3.93,2.29,1.66$. Deze verklaarden respectievelijk 22, 13, en 9\% van de varlantie. Varimax rotatie van deze factoren leidde tot de drie verwachte factoren, warbij elk item het hoogst laadide op die factor, waarvoor het oorspronkelijk was opgenomen (zie tabel 7.1). De uitspraak "Wat ik ook doe, ziek word ik warr- 
tabel 7.1

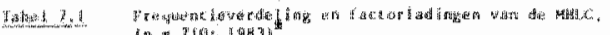

iㅕ엉-

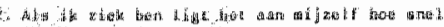

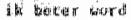

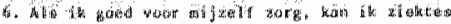
wourkigle h

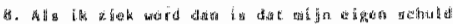

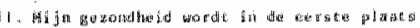

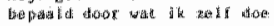

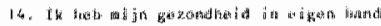

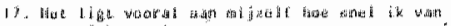

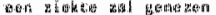

HESE

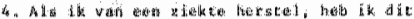

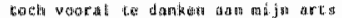

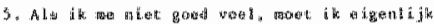

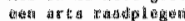

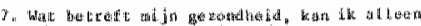

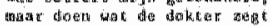

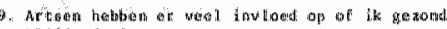
b) is of wile

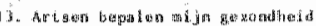

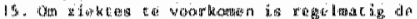

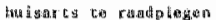

Kans

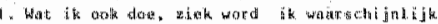
exack

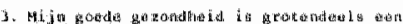

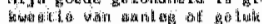

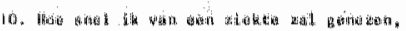

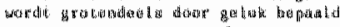

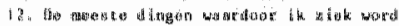

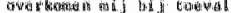

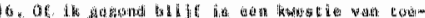

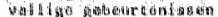

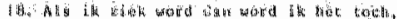

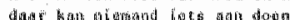

\begin{tabular}{|c|c|c|c|c|c|c|}
\hline (bealint) & 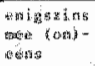 & 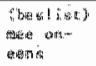 & $\begin{array}{c}5 \text { a } \\
1\end{array}$ & $\begin{array}{c}\text { Bas axy } \\
?\end{array}$ & $\begin{array}{c}5 \text { and } \\
3\end{array}$ & $4 ?$ \\
\hline 33 & 42 & 5 & . & .42 & 等 & मस \\
\hline 88 & 42 & 神 & . 被 & 象 & $-a k$ & . \\
\hline 4 & 34 & 60 & 18 & 30 & .13 & 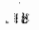 \\
\hline 43 & 48 & 4 & -35 & 63 & .05 & .41 \\
\hline 24 & 40 & 24 & +.05 & Sist & -.01 & .4 \\
\hline 27 & 嘈了. & 漠 & $\because 01$ & .58 & , ist & 1. 34 \\
\hline 20 & 52 & 图 & +5 & $.0 \%$ & $2 \%$ & 3,3 \\
\hline 绐 & 40 & 12 & .54 & w. 07 & " $\alpha$ & ${ }_{n} 24$ \\
\hline 21 & $\leq 6$ & 31 & .69 & .0 .5 & ' & .31 \\
\hline 91 & $4 \pi$ & 40 & .58 & .20 & DI & 70 \\
\hline 6 & 29 & 6 & .60 & .12 & जा & $\because 41$ \\
\hline 13 & 39 & 48 & 69 & .060 & , & $\therefore \Delta$ \\
\hline 116 & 21 & 57 & .36 & $-.0 k$ & 3484 & 2 \\
\hline 35 & $4 j$ & $7=$ & .16 & . Оब & 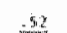 & , 部 \\
\hline 11 & 39 & 50 & .23 & (t) & 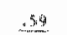 & 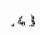 \\
\hline 43 & $4 y$ & 30 & $\cdots .0 !$ & , 绍 & 51! & 多多 \\
\hline 15 & 48 & $3 y$ & .15 & , 04 & 53 & , \\
\hline 75 & 30 & 25 & .56 & $-.0 \%$ & $\therefore 7$ & 27 \\
\hline
\end{tabular}


schijnlijk toch" laadt echter vrijwel identlek op de factor PHLC. Mede ondat het voldoende laadt op de factor CHLC en omdat het theoretisch gezien bij deze factor thuishoort, is dit 1 tem bij de gchaalconstructle alleen voor de schaal CHLC meegenomen. De schalen zijn samengesteld door steeds de zes uitspraken te sommeren.

De interne consistentie van de drie schalen is redelijk tot goed (zie tabel 7.2). Soortgelijke consistenties met deze lijst werden gevonden in de andere steekproeven van het panelonderzoek en in ander onderzoek (Adriaanse e.a. 1984; zie bijlage 6). De interne consistentie-coefficienten komen ook overeen met de door Wallston e.a. (1978a, 1981) genoende coefficienten. De interne consistentie vormt dus een stabiel gegeven voor deze schalen.

Aangezien deze lijst alleen in 1983 aan de respondenten is voorgelegd kunnen geen test-hertest betrouwbaarheden berekend worden. Wel zijn op de aorspronkelijke vertaling van Burink-Withaar e.a. door Alleyn (1983), de test-hertest betrouwbaarheden over een $t i j d s i n t e r v a l$ van zes maanden per uitspraak berekend. Deze correlatie-coefficienten varieerden van .13 tot .56 met een mediaan van .41. Aangenamen mag worden dat indien de testhertest betroumbaarheden op schaal-niveau berekend waren deze let: hoger zauden zijn.

Tabel 7.2 Schaalgegevens van de drie beheersingsorientatieschalen $(n=710,1983)$.

Cronbach"s geniddelde standaard scheefheld alpha deviatie

$\begin{array}{lrrrr}\text { IHLC } & .68 & 22.4 & 4.3 & -.08 \\ \text { PHLC } & .78 & 19.4 & 5.1 & .14 \\ \text { CHLC } & .70 & 19.5 & 5.1 & .02\end{array}$

In tabel $7.2 \mathrm{zijn}$ behalve de interne betrouwbarheid ook de gemiddelden, standaard deviaties en acheefheid van de drie achalen weergegeven. Hieruit blijkt dat de drie schalen normaal verdeeld zijn. In tabel $7.3 \mathrm{zijn}$ de intercorrelatieg tussen de drie schelen weergeven. Hieruit blijkt dat de beide externe orientaties in geringe mate positief samenhangen met de interne orientatie, terwijl de beide externe arientaties wel dulidelijk samenhangen. Hoewel in de literatuur soms ook dergelijke hoge samenhangen gevonden worden (0.a. Larde en Clopton; 1983), is dit hier ten dele te verklaren, doordat de uitspraak "wat ik ook doe, ziek word ik toch" met 
belde orlentaties amenhangt. Deze samenhang tussen de beide externe achalen is ook gevonden bij de andere steekproeven (zie bijlage 6). De relatie tussen de interne en de beide externe orientaties varieert echter nogal. De verhouding interne versus externe beheersingsorientatie ten aanzien van gezondheid is dur geen stabiel gegeven.

Tabel 7.3 Intercorrelaties tussen de drie beheersingsorientatie-achalen $(n=710,1983 ; p$ kleiner dan .001).

1. IHLC -

2. PHLC $.15=$

3. CHLC $\quad .12 \quad .40$

Samenvattend kunnen we zeggen dat het in dit onderzoek gebruikte meetinstrument drie betrouwbare achalen bevat die normeal verdeeld zijn, warvan de IHCL-gcharl vrijwel onefhankelijk is van de twee externe schalen, doch de twee externe achalen niet onafhankelijk van elkaar zijn. Verwacht mag worden dat met de beide externe schalen zodoende veelal dezelfde reaultaten verkregen zullen worden.

\subsection{SOORTGENOOT VALIOITEIT}

\subsubsection{DE ALGEMENE BEHEERSINGSORIENTATIE}

In 1981 is de reapondenten een $11 j$ st met twalf uitspraken voorgelegd, welke beoogde de algemene beheersingsorientatie te meten (0rmel, 1980). Factor-analyse van deze $11 \mathrm{jat}$ leldde tot twee schalen, namelijk een achal met alleen de intern geformuleerde uitapraken (interne beheersingsorientatie) en een schaal met alleen extern geformuleerde uitspraken (externe beheergingsorientatie; zie bijlage 2). Opgemerkt moet worden dat ook hier de externe beheersingaorientatie ans inzlens meer machteloosheid den externe beheersingsorientatie meet. Gemakshalve zullen we hier echter de term externe beheersingsorientatie aanhouden.

In tabel 7.4 is de relatie tussen de algemene en de gezondheidsspecifieke beheeraingaorientatie weergegeven. In deze tabel maar ook in de volgende 
tabellen zullen alleen de samenhengen gepresenteerd worden welke significant (p kleiner dan .05) zijn.

Het blijkt dat tussen de algemene beheersingsorientatie (gemeten in 1981) en de gezondheidsspecifieke beheersingsorientatie (geneten in 1983) een duldelijke relatie bestaat. De beide interne schalen hangen met elkear samen, evenals de externe schalen, terwijl de algemene interne schaal niet samenhangt met de beide gezondheidsapecifieke externe schalen, en de externe schaal niet met de gezondheidsspecifleke interne orientatie. Ondanks een tijdsinterval van twee jas is er dus een duidelljk, hoewel niet echt sterk, verband tussen de algemene en de gezondheldsspecifieke beheersingeorientstie, hetgeen wijst op een duidelijke verwantschap tussen beide.

Tabe1 7.4 Nulde-arde correlatie-coefficienten tussen de algemene en de gezondheidsspecifieke beheersingsorientatie ( $n=710$; 1981 en 1983; alle coefficienten zijn significant bij $p$ is kleiner dan $.05)$.

IHLC PHLE $\underline{\text { CHLC }}$

\subsubsection{GEZONDHEIDS- EN ZIEKTE-OPVATTINGEN}

Behalve via de gezondheidsspecifleke beheersingsorientatle ls ook op andere wijzen gevraagd naar de mate warrin men de eigen gezondheid kan beinvloeden. Zo is aan de respondenten gevraagd aan de hand van een $11 \mathrm{j}$ st wan 8 personen en instanties aan te geven wie volgens hen de meeste invloed heeft op hun gezondheid, en wie vervolgens etc. Zodoende is voor elke persoon of instantie een rangorde verkregen van 8 (meeste invloed) tot 1 (minate invloed). Van deze $11, j$ st personen en instanties zifn de rangorde die men zichzelf en de arts heept toegekend gebrulkt. Ult tabel 7.5 blijkt dat een interne en een niet-arts-orlentatie aanengaat met zichzelf de meeste invloed toekennen. Het ongekeerde geldt voor de relam tie met de arts de meeste invloed toekennen. Met name is ex een duidelijke relatie met de artg-orientatie. Degenen die van mening zijn dat ze zelf de meeste invloed hebben zIjn minder artg-georienteexd, terwi 1 het omgekeerde geldt voor degenen die van mening zijn dat de arts de meeste invloed heeft. 
Verder is an de respondenten gevraagd in welke mate men de eigen gezoniheid denkt te kunnen belnwloeden. Uit tabel 7.5 blijkt dat het antwoord op deze vraag aterker met de interne- en de kans-orientatie samenhangt dan het antwoord op de vrang wie de meeste invloed heeft. Dlt is te verklaren door kiet felt dat met de interne orientatie de mate van invloed gemeten wordt en niet of men van mening is dat men zelf de meeste invloed kan ultoefenen. Een persoon kan van mening zijn dat hijzelf veel invloed heeft op de elgen gezondheid, maar dit impliceert nilet det hij ook vindt dat his de meeste invloed heeft.

Degenen die zich meer verantwoordelijk voelen woor de eigen gezondheid lijken ook meer intern georlenteerd te zijn. Geen relatie is er echter tussen het zich verantwoordelijk voelen en de arts-orientatie. Degenen die de arts veel invloed toekennen voelen zich dus niet minder verantwoordelijk woor de eligen gezondheid dan degenen die de arts weinig invloed toekennen. Wel voelen de kans-georienteerden zich iets minder verantwoordelijk.

Op basis van een aantal uitspraken, welke in 1981 aan de respondenten zijn voorgelegd, zijn een tweetal schalen geconstrueerd (zie bijllage 4), te weten scepsis t.a.v. de medische wetenschap en vertrouwen in de medigche wetenachap.

De mate waarin men sceptisch staat ten opzichte van de medische wetenschap blijkt enigszina negatief samen te hangen met de artsorientatie. De mate waarin men vertrouwen heeft in de medische wetenschap hangt daarentegen positief samen met de artg-orientatie. Degenen die de arts veel invloed toekennen wat hun elgen gezondheid betreft, hebben dus meer vertrouwen in de medische wetenschap. Het vertrouwen hebben in de medische wetenschap is echter nauwelijks gerelateerd aan de interne- en de kansorlentatie.

Tabel 7.5 Nulde-orde correlatie-coefficienten tussen de beheeraingsorientatie en gezondheidsopvattingen $(n=710,1981$ en 1983; alle coefficienten zijn significant bij $p$ kleiner den .05).

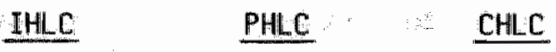

$\begin{array}{lrrr}\text { meeste invloed zelf } & .11 & -.20 & - \\ \text { meeste Invloed arts } & -.10 & .32 & .08 \\ \text { mate van invloed (zelf) } & .22 & -.14 & -.20 \\ \text { mate } v . \text { verantwoordelijkheid } & .20 & - & -.08 \\ & & & \\ \text { scepsis medische wetenschap } & - & -.08 & - \\ \text { vertrouwen in medische wetien. } & - & .32 & .14\end{array}$


Samenvattend kunnen we zeggen dat de relaties tussen de beheersingsorientatie en de gezondheidsopvattingen alle wijzen in de richting van een woldoende conetruct validiteit van de beheersingsorientatie. Deze relaties zijn echter niet sterk, hetgeen ten dele te wijten kan zijn aan het heterogene karakter van de steekproef.

\subsection{DEMOGRAF ISCHE KENMERKEN EN SUBJECTIEVE GEZONDHEIOSTOESTAND}

Een belangrijkk punt bij de bestudering van de beheersingoorfentatie is de wraag of de gezondheidspecifieke beheersingsorientatie samenhangt met de demografische kenmerken en de gezondheidstoestand van de respondent (vraagatelling 1). In de volgende twee paragrafen wordt dit nader onderzocht.

\subsubsection{DEMOGRAF ISCHE KEMMERKEN}

Als demografische kenmerken van de respondenten zijn gebruikt sexe, leeftijd, sociaal-economische status en burgerlijke staat (zie tabel 7.6). Wit tabel 7.6 blijkt dat aexe, leeftijd en sociaal-economische status gerelateerd zijn aan de beheeraingsorientatie. Mannen en jongeren zijn lets meer intern georienteerd, terwijl ouderen en personen met een lagere soclaal-ecanomische status meer arta- en kanomgeorienteerd zijn. Opgenerkt moet worden dat de invloed van sexe duidelijk minder is den de invloed van sociaal-econonische status.

Dat de beheersingsarientatie, in tegenstelling tot hetgeen Wallation en Wallston (1981) meldden, hiler wel gerelateerd is aan enkele denografloche kenmerken, moet warachijnlijk geheel worden toegeachreven ean het gebruik van een heterogenere onderzoekspopulatie dan gebruikelijk is bij onderzoek omtrent de beheersingsorlentatie.

De steekproef is niet evenredig verdeeld naar de genoemde kennerken. Om te voorkomen dat deze kenmerken een vertiekend beeld geven van de cemenhangen tussen de beheersingsorientatie en de andere kenmerken, zal op deze kenmerken gecontroleerd worden. Voor de IHLC zal dus gecontroleerd worden op sexe en leeftijd, terwijl voor de PHLC en de CHLC gecontroleerd zal worden op leeftijd en socisal-economische status.

\subsubsection{DE SUAJECTIEVE GEZONDHEIDSTOESTAND}

In hoofdatuk 4 hebben we geconcludeerd dat personen met een slechtere gezondheidstoestand over het algemeen meer extern en minder intern-georien- 
teerd zijn. On na te gaan of deze relatie ook met de door ons gebruikte 11jst gevonden wordt, zijn in tabel 7.7 de samenhangen tussen de drie indicatoren voor de subfectieve gezondheldatoeatand en de beheersingsorientatle weergegeven. Uit deze tabel blijkt dat alleen en in beperkte mate de arts-orientatie samenhangt met de subjectieve gezondheidatoestand. Arto-georlenteerden voelen zich ieta minder gezond den niet-arts-georienteerden.

Tabel 7.6 De beheersingsorientatie gerelateerd aan enkele denograflsche gegeveris (gemiddelde scores en bij leeftijd correlatie coefficienten; $n=710 ; 1983$ ).

$\underline{I H L C} \quad \underline{P H L C} \quad \underline{\text { CHLC }}$

$\begin{array}{llll}\frac{}{\text { Bexe }} & & & \\ \text { man } & 22.9^{*} & 19.6 & 19.3 \\ \text { vrouw } & 21.9 & 19.2 & 19.7 \\ \text { F-waarde } & (9.47) & (1.06) & (.78)\end{array}$

soc.ec. Klagse

\begin{tabular}{llll}
\hline laag & 22.8 & $20.8^{* *}$ & $20.4^{* *}$ \\
midden & 22.0 & 18.5 & 19.0 \\
hoog & 22.0 & 17.9 & 18.5 \\
F-waarde & $(2.64)$ & $(26.15)^{* *}$ & $(10.08)^{* *}$
\end{tabular}

burgerlijke staat gehuwd, samenwonend niet (meer) gehuwd F-wararde $22.3 \quad 19.4 \quad 19.4$

$22.9 \quad 19.2 \quad 20.0$

Fwarde

$(1.73)(.05)$ (1. 06)

Leeftijd $-.14 * * 26 * *$ $.17 *$

* pleiner dan .01

* p kleiner dan .001

Hierbily gaat het om het algemeen welbevinden. Het antal concrete klachten dat men de week voorafgaand aan het interview heeft gehad, hangt namelijlk niet met de beheersingsorientatie samen. 
Tabe1 7.7 Nulde-orde en partiele correlaties(1) tuissen de beheersingsorientatie en de subjectieve gezondheidstoestand ( $n=710,1983$; alle coefficienten zijn aignificant bij p kleiner dan .05).

$\underline{\text { IHLC }} \underline{\text { PHLC }} \underline{\text { CHLC }}$

$\begin{array}{llll}\text { algemene gezondheid } & -(-) & -.15(-.09) & -.10(-) \\ \text { klachten afgelopen week(2) } & -(-) & -(-) & -(-) \\ \text { Voeg } & -(-) & .12(.08) & .06(-)\end{array}$
(1) Partiele correlaties tussen haakjes:
- IHLC gecontroleerd op sexe en leeftijd
- PHLC en de CHLC gecontroleerd op leeftijd en sociaal- economische status

(2) $n=489$

Nu zijn de door ons gebrulkte gegevens feitelijk minder geachikt om de relatie tussen de beheersingsorientatie en de gezondheidstoestand te beatuderen, aangezien we eerder de respondenten met een slechte gezondheid, namelijk respondenten met een chronische aandoening, wasrvoor men regelmatig de dokter bezoekt, uit het databestand verwijderd hebben.

Een vergelljking tussen deze respondenten met een chronische arandoening en de voor onze studie gebruikte respondenten, leert dat respondenten met een chronische aandoening minder intern- (resp. 20.9 versus 22.4) en meer arto-georienteerd (resp. 22.5 versus 19.4 ) zijn. Dit verschil blifft ook aanwezig indien gecontroleerd wordt woor de demografiache gegevena, namelijk respectievel1jk 21.2 versus 22.3 voor de interne orientatie en 21.5 versus 19.5 voor de artsmorientatie. Geen verschil is er ten aanzien van de kano-orientatie.

Dit betekent dat, evenals in de literatuur, ook in dit onderzoek een aamenhang gevonden is tussen de beheersingsorientatie en de gezondheidstoeatand. Hoewel het niet geheel uitgesloten is dat arts-georienteerden meer geneigd zijn te klagen over hun gezondheid, mag aangenomen worden dat het gevonden verband voornamelijk veroorzalkt wordt doordat de gezondheldetoestand de arts-orientatie beinvloedt. Met andere woorden degenen die ziek worden, worden ook meer arto-georienteerd.

Samenvattend kunnen we dus zeggen dat de gezondheidstoestand de gezondheidspecifieke beheersingsorientatie beinvloedt, en wel zodinig dat bij 
een slechtere gezondheidatoegtand men meer arto- en minder intern-georienteerd rakkt.

Aangezlen in dit onderzoek de respondentien met een duidelijk slechtere gezondheidstoestand uit het databestand verwijderd $z i j n$, hebben we thier wat de gezondheidstoestand betreft met een homogene ateekproef te maken, zodat de beheersingsorientatie bij deze respondenten nauwelijks beinvloedt mordt door de gezondheidstoestand.

\subsection{SAMENVATTING}

In dit hoofidstuk is de operationalisatie van de gezondheidsspecifieke beheeraingsorientatie besproken. Als meetinstrument is een vertaling van de Multi-dimengional Health Locus of Control Scale gebruikt. De drie schalen uit deze lijat bleken een redelijke tot goede interne consistentie te hebben, terwijl de interne schaal vrijwel onafhankeligk was van de beide externe achalen. De beide externe schalen bleken echter niet onafhanke$11 j k$ van elkar te zijn.

Een duldelijke samenhang werd gevonden met twee schalen die de algemene beheersingsorientatie meten. De beide interne schalen bleken onderling samen te hangen, evenals de externe schalen. Tussien de interne en de externe achalen bleek echter geen aamenhang te bestaan.

Ook bleken de gezondheldsepecifleke beheersingsorientatie-schalen op een consiatente wijze samen te hangen met aanverwante gezondheidsopvattingen. Mede omdat de schalen op dezelfde wijze, zoals ook in Amerikaans onderzoek, Bamenhingen met de gezondheidstoestand, kan geconcludeerd worden dat de gebruikte schalen voldoende betrouwbar en valide zijn.

Tot slat is gebleken dat de beheersingsarientatie ook beinvloed werd door leeftljd en aociaal-economische atatus en in beperktere mate door sexe. 
HOOFDSTUK \& DE BEHEERSINGSORIENTATIE BINNEN HET MODEL VAN ROITER

In dit hoofdstuk wordt de beheersingsorientatie bestudeerd vanult het model van Rotter. Eerder hebben we gezien dat volgens dit model de beheersingsorientatie pas invloed heeft op het uitelndelijke gedrag, als het individu de bekrachtiging die volgt op het gedrag belangrijk vindt. Dit betekent dat niet de afzonderlijke beheersingsorientaties samenhangen met het gedrag, maar dat de interacties tussen de beheersingsorientaties en de waarde van gezondheid samenhangen met het gedrag.

De richting van de interacties is voor de interne- en de arto-orientatie duidelijk. Verwacht mag worden dat intern-georienteerden en de arts-georienteerden die gezondheid belangrijk vinden, bepaalde activiteiten op dat gebled ondernemen. Bij de kans-orientatie is deze richting minder duidelijkk. Van kanggeorienteerden mag over het algemeen verwacht wordien dat zij geen activiteiten op dat gebied ondernemen. of dit vooral geldt voor kansgeorienteerden die de bekrachtiging (gezondheid) belangrijk vinden of voor de kans-georienteerden die de bekrachtiging minder belangrijk vinden, is vanuit de theorie niet aan te geven. (Wallston en Wallston, 1981 ).

In hoofdstuk 5 is de stelling dat de beheersingsorientatie van invloed is op het gedrag enigszins afgezwakt door te stellen dat feitelijk bedoeld wordt dat de beheersingsorientatie van invloed is op de intentie tot gedrag. Het voorgaande geldt zodoende ook voor de intentie tot gedrag.

$B i j$ bestudering van de beheersingsorientatie vanuit het model van Rotter is zodoende onze verwachting dat vooral de interacties tussen de beheersingsorientaties en de waarde van gezondheid samenhangen met de intentie tot en met het feitelijke, gerapporteerde gedrag, namelijk dat zowel de Intern-als de arts-georienteerden die gezondheid belangrijk vinden, activiteiten ondernemen. In dit hoofdstuk zal daarom nagegaan worden of de afzonder lijke beheersingsorientaties of juist de interacties tussen de warde van gezondheid en de beheersingaorientatie (vraagatelling 3) gamenhangen met (de intentie tot) gezondheids- en ziektegedrag.

Aangezien in hoofdstuk 5 gesteld is dat de beheersingsorientatie mogelijk (ook) van invloed is op het deadwerkelijk uitvoeren van de intentie tot gedrag, zal ook nagegaan worden of de beheeraingarientatie samenhangt met de relatie tussen de intentie en het feitelijke, gerapporteerde gezondheido- en ziektegedrag (vreagstelling 5 ).

Alvorens we hierop ingaan, zullen we kort stilstaan bij de gebruikte analyae-methode. 


\subsection{DE ANAL YSE-METHODE}

Voor de analyses in dit hoofdatuk hebben we te maken met vier onafhankelijke varlabelen, te weten de drle beheergingsorientatios en de warde van gezondheld. Aangezlen volgena het model van Rotter de interactie tusaen enerzljo de beheersingsorientatie en anderzijds de warde van de bekrachtlging wan invloed is op het gedrag, komen tenminate twee analysetechnieken in aanmerking namelijk variantie-analyse en regressie-analyse (Wallston en Wallston, 1981). Bij regressie-analyse moeten de interactietermen afzonderlijk worden ingevoerd. Echter een regressie-analyse, met zowel de oorspronkelijke variabelen als de interactietermen, levert al anel mult1-collinaritelt op (Lewis en Beck, 1983), aangezien de interacties meestal aterk correleren met de oorspronkelijke variabelen. In dit onderzoek bleken deze correlatles aoms meer dan .70 te bedragen. Vandaar dat afgezien lis van regressle-analyse en variantie- en covariantie-analyse is gebrullkt. Een voordeel van variantie-analyse is dat niet alleen de interacties tussen de afzonderlijke beheersingsorientaties en de waarde van gezondheid berekend worden, maar ook interacties tussen versch11lende beheersingsorlentaties en de waarde van gezondheid, en tussen de beheersingaorientaties onderling. Voor deze varilantle-analyses zijn de drile beheersingsorientaties en de waarde van gezondheid, met behulp van de mediaan, gedichotomigeerd. Zodoende zijn voor elke variantiemanalyse 16 cellen geereeerd.

Aangezien we in dit hoofdstuk het effect van sexe, leeftijd en sociaaleconomische status willen uitschakelen, zijn deze bij een aantal afhankelijke variabelen in de variantie-analyse als covariaten ingevoerd. Alvorens deze zijn ingewoerd, is nagegaan of het effect van de covariaten op de afhankelijke variabele per cel wel gelijk is. Indien aan deze assumptle van homogeniteit van regressie niet wordt voldsan; mag een dergelijke coveriant 1e-analyse nlet uitgevoerd worden (Tabachnick en Fidel1; 1983). Dit bleek echter alechti in én analyae het geval te zijn. Bij de begchrijving van de resultaten (paragraaf $B .3 .3$ ) zal hiervan melding worden gemaakt.

Vervolgens is per afhankelijke variabele met behulp van variantie-analyse nagegaan of, en zo ja, welke covariaten significant samentiangen met de afhankelijke variabele, nadat de beheersingsorientatie en de waarde van gezondheld $21 \mathrm{jn}$ ingevoerd. Covarlanten die niet significant samenhingen $z i \mathrm{Jn}$ in de daaropvolgende (co) varlantie-analyse nilet meegenomen."

In deze laatate (co)variantle-analyse zijn de vier afzonderlijke onafhankelijke varlabelen, evenals alle mogelijke interacties, opgenomen. Aangezien volgens het model van Rotter met name de interacties van belang

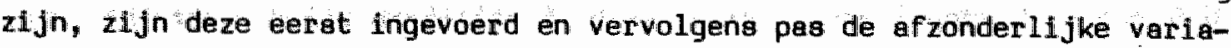
belen. Dit voorkont tevens dat mogelijke effecten van interacties bij de afzonderlijke variabelen significante warden opleveren.

In de volgende paragraaf zullen alleen deze laatste analyses worden ge- 
presenteerd. Welke covarianten uiteindelijk gebruikt zijn, stat in de betreffende tabillen vermeld. Gepresenteerde gemiddelden of percentages zullen hierbij steeds, Indien van toepassing, aangepast zijn op basis van deze covariaten.

Een leatste opmerking die hier van belang $\mathbf{1 8}$, betreft het probleem van toevalstreffers. Aangezien voor dit deel van het onderzoek een groot antal variantle-analyses uitgevoerd worden, mag alleen al op basis van kans verwacht worden dat er significante verbanden gevonden worden. Bij incidentele verbanden moeten we dus rekening houden met de mogelljkheid dat deze louter toevalstreffers zijn. Naarmate verbanden minder incidenteel zijm, zal dit echter minder het geval zijn.

In de volgende paragrafen worden de bewindingen van de diverse (co)variantie-analyses besproken. In de samenvattingen zal steeds een tweedeling gehanteerd worden, namelijk een meer hypothese-toetsend gedeelte ontrent onze verwachtingen op basis van het model van Rotter, en een descriptief gedeelte warin de verbanden, welke niet voorspeld waren, beschreven worden.

\subsection{ZIEKTEGEDRAG}

\subsubsection{INTENTIE TOT ZIEKTEGEDRAG}

Zoals in paragraaf 6.4 .5 .1 beschreven 1 , zi.jn aen de hand van 18 specifieke klachten vier schalen samengesteld, welke de intentie tot zilektegedrag weergeven. Op elke schaal is een (co)variantie-analyse ultgevoerd, waarvan de gevonden $F$-waarden voor alle mogelijke (interactie)-effecten in tabel 8.1 zijn weergègeven.

U1t tabel 8.1 blijkt dat en verschillende (interactie)effecten algnificant zijn. Deze zullen per achasl besproken worden.

\section{-Afwachten}

Als hoofdeffect blijkt de arts-orientatie significant samen te hangen met de mate warin men van plan 18 af te wachten. Arto-georienteerden hebben minder de neiging of te wachten of de klacht vanzelf overgat dan de niet-artsgeorienteerden (reapectievelijk bij 10.4 versus 11.6 klachten). Uit twee drieweg-interacties blijkt det dit vooral geldt voor artg-georlenteerden die gezondheid minder belangrijk vinden en die of niet-kansgeorienteerd (zie tabel 8.2 ) of intern-georienteerd (zie tabel B.3) zijn. 
Tabe 1 8.1 F-waarden verkregen met behulp van (co)variantie-analysies over de intentie tot ziektegedrag $(n=710 ; 1983)$.

$$
\begin{aligned}
& \text { afwachten(1) medicijn- dokter be- iets } \\
& \text { gebruik zocht (2) anders }
\end{aligned}
$$

$\begin{array}{lcccc}\text { I(HLC) } & 2.31 & .88 & 1.38 & 2.87 \\ \text { P(HLC) } & 17.52^{* * *} & .01 & 31.55^{* * *} & 7.84^{* *} \\ \text { C(HLC) } & 2.17 & .27 & .24 & 4.81^{*} \\ \text { W(aarde) } & 2.71 & .09 & 2.72 & .01 \\ \text { IXP } & 3.27 & .26 & 10.73 * * * & 6.55 * * \\ \text { IXC } & .63 & 1.80 & .00 & .31 \\ \text { IXW } & .75 & .19 & .53 & .20 \\ \text { PXC } & .83 & .17 & .75 & .00 \\ \text { PXW } & .03 & .31 & .13 & .36 \\ \text { CXW } & .55 & .92 & 1.27 & .00 \\ \text { IXPXC } & .35 & 1.67 & 1.22 & 1.11 \\ \text { IXPXW } & 4.79 * & .06 & 9.90^{* *} & 4.97^{*} \\ \text { IXCXW } & 5.61^{*} & .52 & 3.48 & .55 \\ \text { PXCXW } & 7.30^{* *} & 1.20 & 5.45 * & .59 \\ \text { IXPXCXW } & 1.15 & 3.99 * & .70 & 1.04\end{array}$

* p kleiner dan .05

* p kleiner dan .01

* p klelner dan .001

(1) leeftijd alo covariant

(2) gealacht, leeftijd en sociaal-economische status als covariaten

Tabel 8.2 Aangepast gemiddelde van antal klachten waarvoor men zou afwachten, verdeeld naar arts-, kans-orlentatie en waarde van gezondheid ( $n=710$;

\begin{tabular}{|c|c|c|c|c|}
\hline$\therefore$ & CHLE & laag & laag & hoog \\
\hline & PHLC & latg & hoog & laag \\
\hline larde & laag & 11.4 & 9.4 & 11.4 \\
\hline & hoog & 11.1 & 11.1 & 12.5 \\
\hline
\end{tabular}
1983). 
Tabel 8.3 Aangepast gemiddelde van aantal klachten waarvoor men zou afwachten, verdeeld naar interne-, arts-orlentatie en waarde van gezondheld $(n=710$; 1983).

\begin{tabular}{|c|c|c|c|c|}
\hline PHLC & lagg & laag & hoog & hoog \\
\hline IHLC & Laag & hoog & Laag & hoog \\
\hline 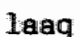 & 11. & 11. & 10.9 & \\
\hline hoog & 11.9 & 11.7 & 10.7 & \\
\hline
\end{tabular}

Uit tabel B.4 blijkt verder nog dat ook intern-georienteerden met een lage kans-orientatie, welke minder waarde aan gezondheid hechten, minder vask zouden afwachten.

Tot slot blijken degenen die veel warde hechten aan gezondheid, en gezondheid toeachrijven aan kans en niet aan de arts, iets vaker de nelging te hebben af te wachten of de klacht niet vanzelf overgaat (zie tabel 8.2 ).

Tabel 8.4 Aangepast gemiddelde van aantal klachten waarvoor men zou afwachten, verdeeld naar interne-, kkang-orlentatie en waarde van gezondheid ( $n=710$; 1983).

\begin{tabular}{|c|c|c|c|c|c|}
\hline & $\begin{array}{l}\text { CHLC } \\
\text { IHLC }\end{array}$ & $\begin{array}{l}\text { laag } \\
\text { laag }\end{array}$ & $\begin{array}{l}\text { laag } \\
\text { hoog }\end{array}$ & $\begin{array}{l}\text { hoog } \\
\text { laeg }\end{array}$ & $\begin{array}{l}\text { hoog } \\
\text { hoog }\end{array}$ \\
\hline \% & man. & & & & \\
\hline \multirow[t]{2}{*}{ wetarde } & laag & 11.1 & 9.7 & 10.9 & 11.3 \\
\hline & thoog & 11.1 & 11.2 & 11.5 & 11.1 \\
\hline
\end{tabular}

-Medicijngebruik

Uit tabel 8.1 blijkt dat alleen de vierweg-interactie significant is. Een dergelijke interactie is, mede gezlen de geringe significantie ( $F=3.99$; $p=.05)$ nauwelijks zinvol te interpreteren. Vandaar dat we hier verder niet op ingaan. 
-Dokter bezocht

Het belangr $1 \mathrm{jkg}$ te effect in deze varientie-analyse wordt veroorzaakt door de artg-orlentatie. Arto-georienteerden zijn meer geneigd bij klachten de arta te bezoeken (reep. bij 6.2 versus 4.7 klachten). Uit de tweeweg-interactle tussen de interne- en de arts-orientatie (zie tabel 8.5 ) blijkt verder dat dit vooral geldt voor intern-georienteerden (resp. 6.7 versus 4.4 klachten) en minder voor de niet-intiern-georienteerden (resp. 5.7 versus $5.0 \mathrm{klachten).} \mathrm{Uit} \mathrm{de} \mathrm{drieweg-interactie} \mathrm{tuesen} \mathrm{de} \mathrm{interne-,} \mathrm{de}$ arteorientatie en de warde van gezondheid blijkt nog dat vooral arts-georienteerden met een interne orientatie, welke gezondheid minder belangrijk vinden, waker de arts zouden bezoeken, namelijk bij 7.3 klachten (zie tabel 0.5 ).

Jabel 8.5 Aangepast gemiddelde van aantal klachten waarvoor men de arts zou bezoeken, verdeeld naar interne-, arts-orientatie en waarde van gezondheid $(n=710 ; 1983)$.

$\begin{array}{rrrrr}\begin{array}{r}\text { PHLC } \\ \text { IHLC }\end{array} & \begin{array}{r}\text { laag } \\ \text { laag }\end{array} & \begin{array}{r}\text { laag } \\ \text { hoog }\end{array} & \begin{array}{l}\text { hoog } \\ \text { leag }\end{array} & \begin{array}{l}\text { hoog } \\ \text { hoog }\end{array} \\ \text { waarde laag } & 5.5 & 4.4 & 5.5 & 7.3 \\ \text { hoog } & 4.6 & 4.5 & 5.9 & 6.1 \\ \text { gemiddelde } & 5.0 & 4.4 & 5.7 & 6.7\end{array}$

Tot slot 18 er nog een klein significant verband met de drieweg-interactie tusaen de arta-, de kans-orientatie en de waarde van gezondheid (zle tabel 8.6 ).

Tabel 8.6 Aangepast geniddelde van aantal klachten, warvoor men de arts zou bezoeken, verdeeld naar arto-, en kans-orientatie en warde van gezondheld $(n=710 ; 1983)$.

\begin{tabular}{|c|c|c|c|c|}
\hline CHLC & Lrag & laag & hoog & hoog \\
\hline PHLC & laag & hoog & laag & hoog \\
\hline laeg & 4.9 & 7.0 & 5.0 & \\
\hline hoog & 5.0 & 5.3 & 4.1 & 6.7 \\
\hline
\end{tabular}


Uit deze tabel blijkt niet alleen dat arts-georienteerden met een lage kans-orientatie, wellke minder waarde hechten an gezondheid, vaker de arts zouden bezoeken, maar ook dat kans-georienteerden met een lage artgorlentatile en welke veel waarde hechten aan gezondheld minder vaak de arts zouden bezoeken.

- Iets anders doen

Uit tabel 8.1 blijkt dat twee hoofdeffecten significant zijn. Kans-georienteerden zijjn minder van plan andere activiteiten te ondernemen (resp. .07 versus .10), evenals arts-georienteerden (resp. .07 versus .10 klachten (logaritme $x+1)$ ). Uit de tweeweg-interactie met de interne orientatie blijkt dat vooral de niet-arta-georienteerden met een hoge interne orlentatie vaker andere activiteiten ondernemen, hetgeen nog duide$11 j$ ker naar voren komt błj diegenen die ook gezondheid minder belangrijk vinden (zie tabel 8.7).

Tabel 8.7 Aangepast gemiddelde van aantal klachten (loge$r$ itme) waarvoor men andere activiteiten zou ondernenen, verdeeld naar interne-, arts-orientatie en wasde van gezondheid $(n=710 ; 1983)$.

$\begin{array}{lllll}\text { PHLC } & \text { laag } & \text { laag } & \text { hoog } & \text { hoog } \\ \text { IHLC } & \text { laag } & \text { hoog } & \text { laag } & \text { hoog }\end{array}$

\begin{tabular}{|c|c|c|c|c|}
\hline werarde & laag & .06 & .16 & .08 \\
\hline & hoog & .09 & .12 & .06 \\
\hline
\end{tabular}

$\begin{array}{lllll}\text { geniddelde } & .07 & .14 & .07 & .06\end{array}$

Allereerat moeten we wat het ziektegedrag betreft concluderen dat geen van de verwachte interacties tusaen de beheersingsorientatile en de warde van gezondheid in de voorspelde richting samenhangen met de intentie tot ziektegedrag. Er zijn wel interacties tuasen de beheersingsorientatie en de warde van gezondheid significant, maar in tegenstelling tot hetgeen vanuit het model van Rotter verwacht mocht worden, zijn het niet degenen die gezondheid belangrijk vinden, mar juist degenen die gezondheid minder belangrijk vinden, die vaker van plan zijn activitelten te ondernemen. Zij zouden vaker de arts bezoeken en andere activiteiten ondernemen. Dit wijst op een consumptieve houding. Gezondheld vinden zijj minder belangrijk, en als ze klachten hebben moet de arts dit maar verhelpen. Verder blijkt vooral een afzonderlijke beheersingsorientatie, namelijk de 
artsmorientatie, samen te hangen met de intentie tot zlektegedrag. Artsgeorientieerden 21 In vaker van plan naar de dokter te gaan - met name de arts-georienteerden die ook intern-georienteerd zijn -, en zij zijn zodoende minder vaak van plan te wachten of andere activiteiten tie ondernemen. Verder blijken kans-georfenteerden ook iets minder vask van plen te zijn andere activiteiten te ondernemen, terwijl intern-georienteerden die niet-arto-georienteerd zijn wel vaker van plan zijn andere activuteiten te ondernemen.

\subsubsection{GERAPPORTEERD ZIEKTEGEDRAG}

Zoals in paragraaf 6.3 .4 .2 beschreven is, zijn de respondenten, die in de week voorafgaand aan het interview klachten hebben gehad, volgens een bepaalde formule verdeeld over vijf ziektegedragingen, te weten "afwachten", "niet voorgeschreven medicijnen gebruiken", "voorgeschreven medicijnen gebruiken", "dokter bezoeken" en "lets anders gedaan". Vervolgens is van deze categorieen elk een afzonderlijke variabele gemaakt, zodat deze als afhankelijke varlabelen ingevoerd konden worden in de variantieen covariantie-analyses.

Alvorens in te gaan op deze analyses, een opmerking vooraf.

De gerapporteerde gedragingen hebben hier betrekking op werkelijke klachten hetgeen bij de intentie tot ziektegedrag niet het geval is. Deze klachten verschillen uiteraard per respondent. Aangezien de ard en de duur van de klacht zlektegedrag-indicerend kunnen zijn is het feitelijk niet juilat respondenten met verschillende klachten samen te voegen. Vergchillen kunnen dan niet alleen toegeschreven worden aan verschillen in beheeraingaorientatie, maar ook aan verschillen in klachten. Een betere methode zou zijn, de analyses te beperken tot respondenten met dezelfide, veel voorkomende klacht. Voor dit onderzoek zou de klacht hoofdpijn bruikbaar zljn, aengezien 66 respondenten dit als hoofdklacht genoemd hebben. Verdere analyse met deze respondenten leert echter dat de variantie bij aommige afhankelijke variabelen, zoals doktersbezoek, dermate gering 19; dat de regreasie-coefficient per groep niet meer homogeen is. Covartantie analyae over deze respondenten kan dearom niet meer worden toegepast. Afzonderlijke analyaeg woor bijvoorbeeld mannen en vrouwen $z 1 \mathrm{j} n$ blj een dergelijk eantal respondenten en de geringe variantie, echter weinig zinvol.

Vandaar dat de analyses toch over alle respondenten met klachten zijn uitgevoerd. Wel zijn de ernet en de duur van de klacht (zie paragraaf 6.3.2) als covariaten in de analyseg betrokken. Bij de interpretatie moet rekening gehouden worden met het feit dat deze correctie niet echt nauwkeurig is. Alvorens de analyses zijn uitgevoerd, is allereerst nagegaan of respondenten met ernstige en minder ernstige klachten (mediaan-splitsing), evenals respondenten met langdurende en kortdurende klachten (me- 
diaan-splitsing), na contrôle op sexe, leeftijd en sociaal-economische status, op de vier onafhankelijke variabelen verschilden. Dit bleek niet het geval.

Van de ulteindelijk uitgevoerde (co)variantle-analyses, no de paralleltoets en de slgnificantie-toets van de covariaten, zijh in tabel 8.8 de F-waarde weergegeven. Opgenerkt kan worden dat de gevonden $F$-waarden beduidend lager zijn dan bij de intentie tot ziektegedrag. Per ziektegedrag zal nader ingegaan worden op de bevindingen van deze (co)variantie-analyses.

Tabel 8.8 F-waarden verkregen met behulp van (co)variantie-analyses over de vijf zlektegedragingen $(n=253 ; 1983)$.

afwach- niet-voor- voorge- dokter be- lets an-

ten (1) geschreven schreven zocht (1) ders (3) medicijnen medicij-

(2) nen

\begin{tabular}{|c|c|c|c|c|c|}
\hline$I(H L C)$ & .73 & .01 & .25 & 3.79 & 2.56 \\
\hline$P(H L C)$ & 1.55 & .00 & .30 & .23 & .12 \\
\hline$C(H L C)$ & .17 & .39 & .37 & .92 & .01 \\
\hline$W($ aarde) & .73 & 1.74 & .72 & 3.61 & $4.56 *$ \\
\hline$I \times P$ & .06 & $4.57 \%$ & .01 & 1.18 & .01 \\
\hline$I \times C$ & .53 & .44 & .02 & .58 & .63 \\
\hline I XWW & 1.21 & 1.97 & .51 & .22 & .35 \\
\hline $\mathrm{PxC}$ & .42 & .13 & .00 & .19 & .32 \\
\hline$P \times W$ & 2.43 & .02 & .15 & .30 & .33 \\
\hline $\mathrm{CxH}$ & .06 & $.1 B$ & 2.04 & .06 & .38 \\
\hline $\operatorname{IXP} \times \mathrm{C}$ & $5.75 *$ & 1.31 & .64 & 2.12 & .05 \\
\hline$I \times P \times W$ & 1.78 & .78 & .07 & .02 & .99 \\
\hline I $\mathrm{CxW}$ & .03 & .22 & .71 & .00 & .40 \\
\hline PxCXW & 2.66 & .01 & .53 & 2.00 & .03 \\
\hline$I \times P \times C \times W$ & $4.40^{*}$ & 1.44 & .15 & .60 & .26 \\
\hline
\end{tabular}

* p kleiner dan .05

(1) duir van de klacht en sociaal-economische status als covariaten

(2) ernst en duur als covarilaten

(3) duur van de klacht als covariaat 
-Afwachten

Uit tabel 8.8 blijkt dat er geen aignificante samenhangen zijn met de afzonder l1jke onefhankelijke variabelen. Wel is er een interactie-effect tusen de drle beheerainglorientatie-schalen en een interactie-effect tussen de vier onafhankelijke variabelen algnificant bevonden.

Tabe1 8.9 Aangepaste percentages respondenten die afgewacht hebben, verdeeld naar de beheersingsorientatie $(n=250 ; 1983)$.

\begin{tabular}{|c|c|c|c|}
\hline PHLC & laag & laag & hoog \\
\hline IHLC & laag & hoog & laag \\
\hline
\end{tabular}

$\begin{array}{llllll}\text { CHLC } & \text { laag } & 32 & 47 & 37 & 21 \\ & \text { hoog } & 39 & 39 & 24 & 47\end{array}$

Uit tabel 8.9 blijkt dat degenen die alleen intern-georienteerd $z$ iljn en degenen die op alle drie de orientaties hoog scoren, vaker afgewacht hebben met hun klacht. Degenen die zowel intern- als arto-georienteerd zijin, evenals degenen die arts- en kans-georienteerd zijn (dus de extern-georienteerden) blijken minder vaak afgewacht te hebben.

Interpretatie van de vierweg-interactie zullen we, mede gezien de lage F-waarde, achterwege laten, aangezien dit weinig zinvol is.

-Medicijnen

Uit tabel 8.8 blijkt dat er een klein verband is tussen enerzijds het gebruik van niet-voorgeschreven medicijnen en anderzijds de interactie tussen de linterne- en de arts-orientatie. In tabel 8.10 is dit verband weergegeven. Hieruit blijkt dat intern-georienteerden met een niet-artsorientatie evenals artg-georienteerden met een niet-interne orientatie relatief liets minder vaak alleen niet-voorgeschreven medicijnen hebben gebruikt.

Het gebruik van voorgeschreven medicijnen blijkt echter in het geheel niet samen te hangen met de vier onafhankelijke variabelen en de interactheo dartussen.

-Doktersbezoek

Hoewel geen variabelen aignificant aamenhangen met het doktersbezoek, is er wel een tendens dat intern-georienteerden de dokter minder bezochten $(F=3.79 ; p=.05 ; 23 \%$ vergus $34 \%)$. Hetzelfde geldt voor degenen die de gezondheid belangrijk vinden $(F=3.61 ; p=.06 ; 23 \%$ versus $33 \%)$.

Uit de varlantie-analyse blijkt verder dat wooral de duur van de klacht wan invloed is op het al of niet naar de dokter gaan (Beta $=.43$ ). 
Tabel B.10. Aengepaste percentages respondenten die nietvoorgeschreven medicijnen hebben gebrulkt, verdeeld naar de interne en de arto-orientatie $(n=250 ; 1983)$.

IHLC laag hoog

$\begin{array}{rrrr}\text { PHLC laag } & 15 & 7 \\ & \text { hoog } & 5 & 15\end{array}$

- Iets anders doen

Uit tabel 8.8 blijkt dat de warde die men hecht aan de gezondheid enigozins samenhangt met het al of niet ondernemen van andere activiteiten, zoals extra rust nemen. Degenen die meer waarde an gezondheid hechten andernemen lets vaker andere activiteiten (25\% versus $14 \%$ ).

Samenvattend kunnen we allereerst opmerken dat geen van de voorspelde interactles tussen de beheersingsorientaties en de warde van gezondheid significant semenhangen met het gerepporteerde ziektegedrag, met ultzondering ven de vierweg-interactie. Varwege de lage F-warde is afgezien van een interpretatie van deze interactie. Ook hier worden dus onze verwachtingen op basis van het model van Rotter nilet bevestigd.

Verder zijn de gevonden verbanden zwakker dan bij de intentie tat zlektegedrag. Ten dele is dit te verklaren doordat de beheersingoorientatie en de warde van gezondheld op eenzelfide, algemeen niveau zijn gemeten als de intentie tot ziektegedrag, terwijl het gerapporteerde zlektegedrag op cen specifieker niveau gemeten is.

Wat de resultaten uit het descriptief gedeelte betreft blijkt dat de warde van gezondheid als afzonderlijke variabele samenhangt met het gerapporteerde zlektegedrag. Degenen die veel warde hechten aan hun gezondheid hebben vaker andere activiteiten ondernomen voor hun klacht, terwijl er ook een tendens is det zij minder de arta bezochten.

Wat de beheersingsorientaties betreft, blijkt dat intern-georienteerden lets vaker afgewacht hebben, terwijl er een tendens is dat zij lets mirder vak naar de dokter z1jn geweest. Intern-georienteerden die ook artageorienteerd zijn, en de extern-georienteerden hebben lets minder vaak afgewacht. Over het geheel genomen moeten we echter concluderen dat de analyses uit deze paragraaf minder duidelijke verbanden hebben opgeleverd. Niet alleen het verschil in niveau tussen de afhankelijke en de onafhankelijke variabelen zal hierbij van belang zijn geweest, maar ook het feit dat de gebruikte opzet minder nauwkeurig ia. Mede ondat bif ziekte 
vooral de klecht zelf van invloed is op hetgeen men onderneemt, en persoonlijkheldskenmerken zoals de beheersingsorientatie, slechts een beperkte rol apelen bij de keuze wan het zlektegedrag, is een nauwkeurige opzet van belang. On de in de inleiding genoemde reden was dit echter niet mogelijk.

Een andere mogelljkheid is, warop in de volgende paragraaf nader zal worden teruggekomen, dat de beheersingsorientatie niet alleen van invloed is op de intentie maar ook op de relatie tursen de intentie en het gedrag. Het is niet uitgesloten dat het effect van de beheersingsorientatie op de relatie intentie en gedrag, het effect op de intentie te niet doet.

\subsubsection{DVEREENSTEMMING TUSSEN INTENTIE EN GERAPPORTEERDE ZIEKTEGEDRAG}

In hoofdstuk 5 is opgemerkt dat de beheersingsorientatie mogelijk van invloed is op de relatie tusaen de intentie en het feitelijke gedrag. In deze paragraaf willen we op deze relatie ingaan wat het ziektegedrag betreft. Hierbij moet echter wel rekening gehouden worden met het genoende verschil in niveau tussen de intentie en het gerspporteerde gedrag in dit onderzoek. De intentie is immers niet gemeten la de intentie van een in dividu in een beparalde aituatie met een specifieke klacht, maar als een algemene intentie tot ziektegedrag.

Ondenks dit niveau-verschil blijft het interessant na te gaan of en zo ja hoe de beheersingsorientatie de samenhang tussen de intentie en het gedrag beinvloedt. In deze analyses is het medicijngebruik niet betrokken. In tabel 8.11 zijn de partiele correlaties voor de verschillende subgraepen weergegeven. De aubgroepen zijn hierbij steeds samengesteld op basis van de waarde van gezondheid en éen beheersingsorientatie-schaal. Het totale antal respondenten 1 s dus steeds gesplitat in 4 subgroepen, bijvoorbeeld in hoog Intern en hoog waarde, hoog intern en laag waarde, laag intern en hoog waarde, en laag Intern en laag waarde.

\section{- Afwachten}

Uit tabel 8.11 blijkt dat vooral de interne orientatie van belang is voor de samenhang tussen de intentie en het gedrag, teminste voor wat "het afwachten" betreft. Bij intern-georienteerden is de samenitang tussen be1de beduldend sterker, zeker voor degenen die ook gezondheid belangrijk vinden. Toch blijkt voor degenen die gezondheid belangrijk vinden het verachil in grootte van de correlatie-coefficienten tussen de intern- en de niet-intern-georienteerden nilet significant $(z=1.54)$. Verder is er nog een verachil tusgen artg-georienteerden die gezondheid belangrijk vinden en die gezondheid minder belangrijk vinden. Ook dit verschil is echter niet significant $(z=1.62)$. 
Tabel 8.11 Partiele correlaties (1) tussen de intentie tot en het gerapporteerde zlektegedrag (tussen hakkjes het antal personen; 1983 ).

\begin{tabular}{|c|c|c|c|c|c|c|}
\hline \multicolumn{3}{|c|}{ ziektegedrag } & \multicolumn{2}{|c|}{ dokter bezoeken } & \multicolumn{2}{|c|}{ Lets anders } \\
\hline Malarde & hoog & laag & hoog & laag & hoog & laag \\
\hline IHLC+ & $.45 * *(46)$ & $.33 * *(73)$ & $-.04(46)$ & $.06(73)$ & $(46)$ & $.02(73)$ \\
\hline IHLC- & $.15 \quad(45)$ & $.12:(79)$ & $-.21(45)$ & $.04(79)$ & (45) & $.18(79)$ \\
\hline PHLC+ & $.41 * *(40)$ & $.11 \quad(78)$ & $-.21(40)$ & $-.22 *(78)$ & $(40)$ & $.16(78)$ \\
\hline PHLC- & $.28 *(51)$ & $.31 * *(74)$ & $.04(51)$ & $.27 *(74)$ & $.43 * * *(51)$ & $.03(74)$ \\
\hline CHLC+ & $.45 * *(36)$ & $.23 *(75)$ & $.09(36)$ & $.02(75)$ & $.27 \quad(36)$ & $.04(75)$ \\
\hline CHLC- & $.27 *(55)$ & $.26 *(77)$ & $-.12(55)$ & $.03 \quad(77)$ & $.38 *(55)$ & $.14(77)$ \\
\hline
\end{tabular}

Totael $\quad .32 * *(91) \quad .20(152)-.10(91) \quad .00(152) .31 * *(91) .09(152)$

(1) Gecontroleerd voor sexe, leeftijd, sociaal-economische status; en ernat en duur van de klacht.

* p kleiner dan .05

* p kleiner den .0l.

** p kleiner dan .001

-De dokter bezocht

Uit tabel 8.11 blijkt dat het al of niet naer de dokter gaen nauwelijks samentiangt met de intentle deartoe. Situationele factoren, zoalo de klacht zelf, zullen hlerbij een veel belangrijkere rol spelen. Enige betekenis kan de arte-orlentatie hlerbij hebben. Blj de arto-georlenteerden 18 er een negatieve samenhang tussen de intentle en het gedrag. Dit blijkt voornamelijk veroorzaakt te worden doordat artg-georlenteerden die minder vaak de intentie hebben de arts te bezoeken, relatief vaker de arts bezoeken dan de andere respondenten. Het verschil tussen arts-georlenteerden en de niet-arts-georienteerden die gezondheld minder belangrijk vinden is significant $(z=3.02)$. 
- Ieta anders doen

Wat de relatle intentie en gedrag bij het ziektegedrag "iets anders doen" betreft, valt met name de rol van de warde van gezondheid op. Bij degenen die gezondheld belangrijk vinden is deze relatie beduidend sterker den blj degenen die gezondheid minder belangrijk vinden (zie tabel 8.11 ; laatste rij), hetgeen echter geen significant verschil oplevert $(z=$ 1.71). Dit vergehil is ieta groter bij de niet-arts-georienteerden $(z=$ $2.30)$.

Samenvattend kunnen we zeggen dat de relatie tussen de intentile en het gerapporteerde ziektegedrag varieert al naar gelang het betreffende ziektegedrag. Met name bij het naar de dokter gaan is er nauwelijks een relatie tuasen de intentie en het gedrag. Waarschijnlijk speelt hierbij een rol dat gebruik gemaakt is van een algemene mat voor de intentie.

De relatie intentie-gedrag varieert echter ook naar gelang de beheersingsorlentatie, hoewel dit in de meeste gevallen niet significant is. De overeenkomat tusaen de intentie tot en het feitelijk naar de dokter gaan 18 grater bij de niet-arta-georienteerden die gezondheid minder belangrijk winden dan bij de arts-georienteerden: De avereenkomst met betrekking tot andere activiteiten ondernemen, blijkt bij de niet-arts-georienteerden die gezondheid belangrijk vinden, hoger te zijn dan bij de nietarts-georienteerden die gezondheid minder belangrijk vinden. Verder is er een duidelijke tendens dat de relatie tussen de intentie tot en het feitelljk afwachten bij intern-georienteerden sterker is dan bij niet-intern-georilienteerden.

Tot slot is er een tendens dat de warde die men hecht aan gezondheid relevant is voor de overeenkomst tussen de intentie en het feitelijke gedrag. Bij degenen die gezondheid belangrijk vinden is de overeenkomst tussen de intentie tot en 'iets anders doen' groter dan bij degenen die gezondheid minder belangrijk vinden.

\subsubsection{SAMENVATTING}

Wat de intentle tot en het gerapporteerde ziektegedrag betreft kunnen we concluderen dat de op basis van het model van Rotter verwachte verbanden niet ziJn aangetroffen. De interactie tussen de beheersingsorientatie en de waerde van gezondheld bleek wel samen te hangen met de intentie tot ziektegedrag, mar in tegengestelde richting. Juist degenen die gezondheld minder belangrijk vinden, zijn vaker van plan activiteiten te ondernemen. Verder bleken de afzonderlijke beheersingsorientities, al of niet in onderlinge linteractie, samen te hangen met de intentie tot en het gerapporteerde zlektegedrag, terwijl bij het gerapporteerde gedrag ook de afzonderlijke warde van gezondheid samenhing met het ondernemen van andere activiteiten. 
Dok bij de samenhang tusaen de intentle tot en het feltelljk gedrag is de interactie tusaen de beheeraingsorlentatie en de waarde van gezondheld nauwelijka aanwezlg. Wel is er een tendens dat bij degenen die veel waarde hechten aan gezondheld deze bamenhang hoger is voor het ondernemen van andere activiteiten. Dit geldt voorel voor de niet-arts-georienteerden. Verder blijkt dat bij niet-arts-georienteerden die gezondheid minder belangrijk vinden de samenhang tussen intentie en feitellijk gedrag ten aanzien van het bezoeken van de arts groter is dan bijarts-georienteerden. Bij arts-georienteerden is deze samenhang zelfs negatief.

\section{B.3 GEZDNDHE IDSGEDRAG}

\subsubsection{ALIGEMENE LEEFWIJZE}

Zoals in hoofdstuk 6 reeds is beschreven, is het niet mogelijk gebleken een algemene mat voor gezondheldagedrag samen te stellen. Wat de algemeine leefwijze betreft moeten we ons den ook tevreden stellen met twee lindicatoren, namelijk de eigen beoordeling wan de respondenten, en de mate waarin men bewust is van de eigen leefwijze. In tabel $8.12 \mathrm{zijn}$ de betreffende $\mathrm{F}$-waarden weergegeven.

-Beoordeling eigen leefwijze

Uit tabel 8.12 blijkt dat twee hoofdeffecten gerelateerd zi.jn aan de mate waarin men de eigen leefwijze gezond windt, namelijk de kang-orientatie en de waarde van gezondheid.

Kans-georienteerden beoordelen de eigen leefwijze als gezonder (5.6 versus 5.4) evenals degenen die gezondheid minder belangrijk vinden ( 5.6 versus 5.5). Verder blijkt uit de drieweg-interactie (zie tabel 8.13 ) dat met name kanø-georienteerden die ook een hoge arto-orientatie hebben en gezondheid minder belangrijk vinden, hun leefwijze gezond vinden, terwijl de niet-kans-georlenteerden, die niet-arta-georienteerd zijn, mar gezondheld belangrijk vinden hun leefwijze minder gezond vinden.

-Bewust zijn eigen leefwijze

Twee onafhankelijke variabelen hangen met de mate van bewust zijn samen, namelijk de interne- en de arto-orientatie. Intern-georienteerden evenala niet-artsgeorienteerden, blijken meer zaken te kunnen aangeven die gezond of ongezond $z i j n$ an hun leefwijze (resp. 4.8 versus 4.1 , en 4.7 versus 4.2).

Uit tabel 8.14 blijkt dat van de respondenten die gezondheid belangrijk vinden, de intern-georienteerden die niet-kans-georienteerd zijn meer ten aanzlen van gezondheid rellevant geachte zaken kunnen aangeven dan de niet-intern-georienteerden, die kans-georienteerd zijn. 
Tabel 8.12 F-waerden verkregen m.b.*. covariantie-analyge over de algemene leefwilze $(n=710 ; 1981,1983)$.

$\begin{array}{ll}\text { beoordeling } & \text { bewust zijn } \\ \text { leefwijze (1) } & \text { leefwijze (2) }\end{array}$

$\begin{array}{lcc}I(H L C) & .36 & 6.48^{*} \\ P(H L C) & 1.65 & 5.61^{*} \\ C(H L C) & 6.02^{*} & 2.86 \\ W(\text { a日rde) } & 3.86^{*} & .49 \\ I \times P & .05 & 1.18 \\ I \times C & .04 & .05 \\ I \times W & .76 & .27 \\ P \times C & 1.11 & .94 \\ P \times W & .03 & 1.29 \\ C \times W & .02 & 1.97 \\ I \times P \times C & .61 & .18 \\ I \times P \times W & .32 & 1.27 \\ I \times C \times W & .01 & 5.81^{*} \\ P \times C \times W & 6.03^{*} & .04 \\ I \times P \times C \times W & 2.69 & 1.27\end{array}$

* p kleiner dan .05

(1) sexe en leeftijd alg covariaten (1983)

(2) aexe en sociaal-economische status als coveriaten (1981)

Tabel 8.13 Aangepaste gemiddelde beoordeling van de eigen leefwijze $(n=710 ; 1981)$

$\begin{array}{cccccc} & \text { CHLC } & \text { laag } & \text { laag } & \text { hoog } & \text { hoog } \\ & \text { PHLC } & \text { laeg } & \text { hoog } & \text { laag } & \text { hoog } \\ \text { waarde } & \text { laag } & 5.6 & 5.5 & 5.6 & 5.8 \\ & \text { hoog } & 5.3 & 5.4 & 5.6 & 5.6\end{array}$

Verder blijken ook de niet-intern-georienteerden die niet-kans-georienteerd zijn en weinig waarde hechten aan gezondheid, relatief weinig van dergelijke zaken te kunnen aangeven. 
Tabel 8.14 Aangepaste geniddelde zaken die gezond of ongezond zijn volgens de respondenten $(n=710,1981)$.

$\begin{array}{cccccc}\text { CHLC } & \text { laag } & \text { laeg } & \text { hoog } & \text { hoog } \\ \text { IHLC } & \text { laag } & \text { hoog } & \begin{array}{l}\text { laeg } \\ \text { hoog }\end{array} \\ \text { waarde } & \text { laeg } & 3.8 & 4.9 & 4.4 & 4.3 \\ & \text { hoog } & 4.8 & 5.1 & 3.4 & 4.8\end{array}$

Samenvattend kunnen we zeggen dat er een verband in de voorspelde richting gevonden is, namelijk dat intern-georlenteerden die gezondheid belangrijk vinden, meer zaken omtrent hun leefwijze kunnen aangeven den de andere respondenten.

Verder is gebleken det kans-georienteerden evenals degenen die gezondheild minder belangrijk vinden, hun leefwijze sls gezonder beoordelen. Aangezlen kans-georienteerden die gezandheid minder belangrijk vinden, minder gezondheidarelevante zaken weten aen te geven omtrent hun leefwijze, dan intern- en niet-artsgeorienteerden, betwijfelen we of kans-georienteerden deadwerkelijk gezonder leven.

\subsubsection{ROOKGEWOONTES}

Wat de rookgewoontes betreft blijkt uit tabel 8.15 dat er vrijwel geen significante verbanden zijn. Geen enkele interactie blijkt signiflcant aemen te hangen met de rookgewoontes. Alleen de kano-orlentatie is gerelateerd an zowel het al of niet roken, als an het al of niet vroeger gerookt hebben. Kans-georlienteerden roken leta vaker dan nilet-kans-georfenteerden, namelijk 54\% versus $45 \%$ en als ze niet roken blijken ze vaker noolt gerookt te hebben, namelljk 57\% versus $45 \%$.

Aangezien uit tabel 8.15 ook blijkt dat kans-georienteerden niet minder vaak een poging doen on te stoppen met roken, kunnen we ult het voorgaende afleiden dat bij kano-georienteerden pogingen om te atoppen met roken vaker mialukken dan bij de niet-kang-georilenteerden. 
Tabel 8.15 F-wasden verkregen met behulp van (co)variantieanalyses over de rookgewoontes.

roken(1) vroeger ge aantal si- getracht te $\begin{array}{llll} & \text { rookt (2) } & \text { garetten (3) } & \text { stoppen } \\ (n=710) & (n=359) & (n=322) & (n=351)\end{array}$

$\begin{array}{lcccr}\text { I(HLC) } & 2.56 & 1.44 & 1.52 & .03 \\ \text { P(HLC) } & 3.29 & 2.06 & 1.58 & .30 \\ \text { C(HLC) } & 6.17^{*} & 5.00 * & 2.92 & 1.32 \\ \text { W(aerde) } & .01 & .03 & .64 & .00 \\ \text { IXP } & .34 & .71 & .45 & .32 \\ \text { IXC } & 2.46 & .28 & .04 & .62 \\ \text { IXW } & 2.42 & 2.34 & .07 & .12 \\ \text { PXC } & .21 & 1.77 & .30 & .64 \\ \text { PXW } & .26 & .00 & .01 & .16 \\ \text { CXW } & .37 & .58 & .07 & .44 \\ \text { IXPXC } & .02 & .42 & .00 & .40 \\ \text { IXPXW } & .81 & .09 & .46 & .56 \\ \text { IXCXW } & 1.54 & 2.85 & .00 & 2.77 \\ \text { PXCXW } & .84 & .03 & .00 & .67 \\ \text { IXPXCXW } & .03 & 2.64 & .11 & .36\end{array}$

* pleiner dan .05

(1) aexe en leefti.jd als covariaten

(2) gexe alo covariat

(3) sexe en sociaal-economische status als covariaten

Dit blijkt duldelijk uit tabel B.16, war de aangepaste percentages berekend zi.jn voor de ex-rokers en degenen die trachten te stoppen met roken. 50\% van de niet-kans-georienteerden 18 het gelukt te stoppen met roken, terw $J 1$ dat percentage bij de kans-georienteerden slechts $38 \%$ bedragt. Met andere woorden de samenhang tussen de intentie en het feitelijk volbrengen van het atop-gedrag is bij kans-georilenteierden minder aterk dan bij de nilet-kansgeorienteerden. 
Tabel 8.16 Aangepaste percentages respondenten met een geslaagde en/of mislukte poging te stoppen met roken, verdeeld naar de kano-orientatie (1983).

$\begin{array}{lll}\text { CHLC } & \text { laag } & \text { hoog } \\ & (n=213) & (n=173)\end{array}$

$\begin{array}{lcc}\text { geslagade poging } & 50 & 38 \\ \text { mislukte poging } & 50 & 62 \\ & - & - \\ \text { Totaal } & 100 & 100\end{array}$

Opgemerkt moet worden dat de vergelijking die we maken wellicht niet helemaal correct is, aangezien voor de ex-rokers de geslaagde poging tot atoppen vele jaren geleden plaats gevonden kan hebben, terwijl aan de rokers alleen over het afgelopen jaar gevraagd is naar stoppogingen.

Rokers die al vaker getracht hebben te stoppen en nu gedesillusioneerd geen poging meer ondernemen, zullen buiten de bovengenoende groep vallen. Het is echter onwarschijnlijk dat dit de bovengenoemde resultaten teniet zou doen. Eerder mag asingenomen worden dat dit het effect zou versterken.

\section{B.3.3 ALCOHOLGEBRUIK}

Evenals voor de voorgaande variantie- en coveriantie-anelyses, 18 voor de analyses over het alcoholgebruik eerst de toets voor homogene regressies uitgevoerd. In tegenstelling tot de voorgaande analyses bleek deze voor de afhankelijke variabele "al of niet wel eens alcohol gebruiken" algniflcant. Deze toets bleek echter niet gignificant als hij werd uitgevoerd voor mannen en vrouwen afzonderlijk. Vandaar dat de covariantie-analyse over deze afhankelijke variabelen voor mannen en vrouwen afzonderlijk is uitgevoerd (zie tabel B.17). 
Tabel 8.17 F-waarden verkregen m.b.v. (co)variantie-analyses over het licoholgebrulk (1983).

$\begin{array}{llll}\text { alcoholge- } & \text { vroeger (2) } & \text { getracht frequen- antal(4) } \\ \text { bruikers } & \text { alcohol } & \text { te stop- tie(3) } & \text { glazen } \\ & \text { gedronken pen } & & \text { per keer }\end{array}$

man- vrour
nen

$(n=336) \quad(n=374) \quad(n=129) \quad(n=590) \quad(n=590) \quad(n=521)$

\begin{tabular}{|c|c|c|c|c|c|c|}
\hline $\mathbb{I}(\mathrm{HLC})$ & .16 & .00 & .78 & 1.08 & .82 & 3.09 \\
\hline $\mathbb{P}($ HLC $)$ & .01 & .67 & 2.91 & 3.44 & 1.52 & 1.26 \\
\hline $\mathrm{C}(\mathrm{H} \perp \mathrm{C})$ & 1.37 & 2.58 & .01 & $6.30 *$ & .02 & .10 \\
\hline$W($ ararde $)$ & .15 & $5.47 *$ & .72 & 3.52 & .31 & .07 \\
\hline IxP & 3.69 & 2.80 & $6.69 *$ & 2.00 & 1.73 & 3.50 \\
\hline$I \times C$ & .80 & .16 & $6.79 *$ & 2.35 & .12 & 3.41 \\
\hline IXW & .44 & .00 & 2.79 & .02 & 3.69 & 3.44 \\
\hline$P \times C$ & .33 & 1.59 & .17 & 1.76 & .33 & 1.21 \\
\hline$P \times W$ & .42 & .67 & .17 & 1.83 & .00 & .25 \\
\hline$C \times W$ & .57 & 3.67 & 1.47 & .02 & .98 & .46 \\
\hline$I \times P \times C$ & .95 & .03 & 1.03 & 3.68 & .90 & .05 \\
\hline IxPxW & .63 & .01 & .01 & .06 & .40 & .02 \\
\hline$I \times C \times W$ & .12 & 1.10 & .24 & .03 & .28 & .76 \\
\hline PxCXW & .96 & .15 & .20 & 3.43 & 1.81 & .07 \\
\hline $\mathrm{I} \times \mathrm{P} \times \mathrm{C} \times \mathrm{W}$ & .10 & .00 & .49 & .29 & 1.25 & 2.31 \\
\hline
\end{tabular}

* pleiner dan .05

(1) leeftlljd als covariaat

(2) aexe als covarlat

(3) sexe en aclat-economische status als covariaten

(4) sexe, leeftijd en sociaal-economische statius als covariaten

Uit tabel 8.17 blijkt dat bij mannen de beheersingsorientatie niet significant samenhangt met het al of niet wel eens alcoholhoudende drank drinken. Het interactie-effect tusgen de interne- en de arts-orientatie is nlet significant, volgens de door ons gehanteerde norm van $p$ kleiner dan .05, maar wel vernoemenswaardig. Arto-georienteerden met een interne 
orientatie drinken lets minder dan orts-georienteerden met een niet-interne-orlentatie (resp. 89\% versus 95\%).

Bif vrouwen hangt vooral de warde die men hecht aan gezondheld samen met het al of nlet drinken. Vrouwen die gezondheld belangrijker vinden drinken vaker den vrouwen die gezondheld minder belangrijk vinden (resp. B1\% versus 71\%). Met name vrouwen die kans-georienteerd zijn en gezondheld minder belangrijk winden, drinken minder vaak $(63 \%)$.

of degenen die tegenwoordig geen alcohol drinken, vroeger wel of niet alcohol dronken, hangt samen met twee interacties, te weten de interactle tussen de interne- en de arts-orientatie en de interactie tussen de interne-en de kans-orientatie (zle tabel 8.18).

Tabel 8.18 Aangepaste percentages ex-alcohol-gebruikers $(n=120 ; 1983)$.

$8.18 \mathrm{a}$

PHLC laag hoog

$\begin{array}{llll}\text { IHLC } & \text { laag } & 25 & 63 \\ & \text { hoog } & 37 & 18\end{array}$

8.18b

$\underline{\text { CHLC }}$ laeg: hoog

$\begin{array}{llll}\text { IHLC } \quad \text { laag } & 42 & 30 \\ & \text { hoog } & 21 & 51\end{array}$

Uit tabel $8.18 a$ en b blijkt dat vooral de intern-georienteerden met een arts-orientatie of met een niet-kans-orientatie minder valk gestopt z1jn met het drinken ven alcohol. Z1j hebben dus vaker nooit alcohol gedronken. Arts-georienteerden met een niet-interne-orientatie zifin dasrentegen wel vaker gestopt. Hetzelfde, masr in mindere mate, geldt voor de kansgeorienteerden met een interne-orientatie. Zij hebben vaker een geslaagde stoppoging gedaen.

Wat de mislukte stoppogingen betreft blijkt uit tabel 8.17 dat met name de kans-orientatie hierbij van belang is. Kano-georienteerden hebben in het afgelopen jaar vaker een mislukte poging gedaan on definitlef te stoppen met drinken (6\% versus $1 \%$ ). of dit betekent dat bij kans-georien- 
teerden de stoppogingen vaker mislukken, of dat zij meer stoppogingen ondernemen valt uit deze gegeveno niet af te leiden. Vandaar dat een nieuwe covariantie-analyse 18 uitgevoerd met uitsluitend degenen die gestopt $z 1$ In en degenen die een mislukte poging daartae hebben gedaan $(n=67)$. Wat de latste groep betreft geldt dezelfde opmerking als bij roken, namelijk dat dit alleen degenen zijn die thet afgelopen jarr een poging tot stoppen ondernomen hebben. Deze analyae leverde twee significante verbanden op, namellgk voor de artor orientatie $(F=5.47$; p kleiner dan .05) en de drieweg-interactle tussen de arts en kans-orientatie en de warde van gezondhefd $(\mathrm{F}=5.85, \mathrm{p}$ klelner dan .05). Van degenen die een stoppoging ondernomen hebben, blijken arts-georienteerden minder vaak een geslaagde poging gedaen te hebben ( $53 \%$ versus $78 \%$ ). Wit de drieweg-interactie is verder nog af te leiden dat vooral bij degenen die extern-georienteerd zijn en gezondheid belangrijk vinden minder personen erin slagen te stoppen met drinken, namelijk 28\%, in tegenstelling tot degenen die niet-extern-georienteerd zijn (81\%).

Uit deze gegevens wordt duidelfjk dat niet zozeer de kans- maar veeleer de arts-orientatie van belang is voor het wel of niet slagen van een atoppoging. Overigens wordt dat niet veroorzaakt doordat de arts-orientetie voor de kans-arientatie in de covariantie-analyse is opgenomen. Omdraaing van beide orientaties leverde hetzelfde effect op. Zadoende kunnen we atellen dat vooral bij arts-georienteerden de relatie tussen de intentie- en het gedrag minder sterk is. Met name als zij ook kans-gearienteerd ziljn en gezondheld belangrijk vinden. Deze relatie is daarentegen sterker bij degenen die niet-extern-georienteerd zijn en gezondheid minder belangrijk vinden.

Tot alot is nog bij degenen die wel eens drinken nagegaan of de beheersingaorientatie gerelateerd is aan het aantal dagen per week dat men alcohol drinkt en het aantal glazen dat men per jaar drinkt. Geen van de effecten $z i j n$ echter aignificant.

Samenvattend kunnen we zeggen dat het op basis van het model van Rotter verwachte interactie-effect tussen de beheersingoorientatie en de warde van gezondheld alleen gevonden is bij het al of niet slagen van een stoppoging. Niet-extern-georienteerden die gezondheid belangrijk vinden ondernemen meer gealaagde pogingen.

In het descrlptleve gedeelte van de analyses bleek dat de afzonderlijke beheeraingsorientatles nauwelijks differentleren tussen degenen die wel eens alcohol drinken en degenen die dat noolt doen. Wel blijken er meer vrouwen die gezondheid belangrijk vinden alcohol te drinken. Aangezien we geen enkele verklaring kunnen geven voor dit verband, veronderstellen we dat dit én van de verbanden is die opgevat moeten worden als toevalstreffer. De afzonder 1 ijke beheeraingsorientaties hangen wel enigazins aamen met het stoppen van alcohol drimken. Van degenen die geen alcohol drinken blijken vooral de arts-georienteerden met een lage interne orientatie en de intern-georienteerden met een lage kang-orientatie vroeger 
alcohol gedronken te hebben, terwijl van degenen die nu alcohol drinken vooral de kans-georienteerden wel eens een mislukte stoppoging gedaan hebben. Van degenen die wel eens een stoppoging gedaan hebben, blijken vooral de arts-georienteerden minder vaak een geslaagde poging gedaan te hebben.

Geen verschil was er ten aanzien van de frequentie en het aantal glazen per keer.

\subsubsection{LICHAAMSBEWEGING}

In tabel $8.19 \mathrm{zijn}$ de gevonden $\mathrm{F}$-wasrden voor lichaamsbeweging weergegeven. Uit deze tabel blijkt dat geen significente samenhangen gevonden zijn voor het wel of niet iets aan lichaamsbeweging doen en het al of nift vroeger iets aan lichaamsbeweging gedlaan hebben. Met andere woorden de beheersingsorientatie differentieert niet tussen degenen die nu lets aan lichaamabeweging doen, degenen die vroeger iets an beweging gedaan hebben en degenen die nooit iets an beweging gedaan hebben.

Wel blijkt bij degenen die nu lets aan lichaamsbeweging doen, het aantal uren dat men hieraan besteedt samen te hangen met de kans-orientatle. Kane-georienteerden besteden meer uren per week aan lichaamsbeweging dan de niet-kang-georienteerden (.57 versus .62 (logaritme $(x+1))$.

Verder blijkt uit tabel 8.19 dat de mate warin men van plan i. geweest om meer aan lichaamsbeweging te doen samenhangt met enkele interacties. Uit deze interacties komt naar voren dat wooral intern-gearienteerden met een niet-kans-orientatie vaker van plan zijn geweeat om meer tijd aan lichaansbeweging te gaan beateden (1.8 versus 1.6). Uit de drieweg-interactie blijkt dat dit vooral geldt voor degenen die naast een interne- en een niet-kano-orlentatlie, ook arts-georienteerd $\boldsymbol{i j}$ ijn (1.8 versus $\mathbb{1} .7$ voor de niet-arto-georienteerden), terwijl degenen die arts-georienteerd zifn en niet-intern- en niet-kana-georienteerd, dus de pure arts-georienteerden, het minst vaak van plan $21 j n$ geweest om meer aan lichaamabeweging te gaen doen (1.4). Verder blijken oak intern-georienteerden welke gezondheld belangrijk vinden vaker van plan geweest te $z i j$ in om meer tijd aan lichaamsbeweging te gaan besteden (1.8 versus 1.6 ), terwij1 uit de drieweg-interactie blijkt dat dit vooral geldt voor de intern-georienteerden die niet alleen gezondheid belangrijk vinden maar ook niet-arts-georienteerd zifn ( 1.8 versus 1.7 voor de arts-gearienteerden). Degenen die zowel arts- ale intern-georienteerd zijn, maar gezondheld niet belangrijk vinden blijken het minst vaak van plan geweest te zijn meer aan lichamsbeweging te gaan doen $(1,4)$. 
Iabel B.19 F-waerden werkregen m.b.v. (co)varientie-analyaes over lichaamabeweging (1983).

niet/wel vroeger aantal plan meer

Lichaems- licheams- uren(3) lichamsbe-

beweging (1) beweging(2) meging(1)

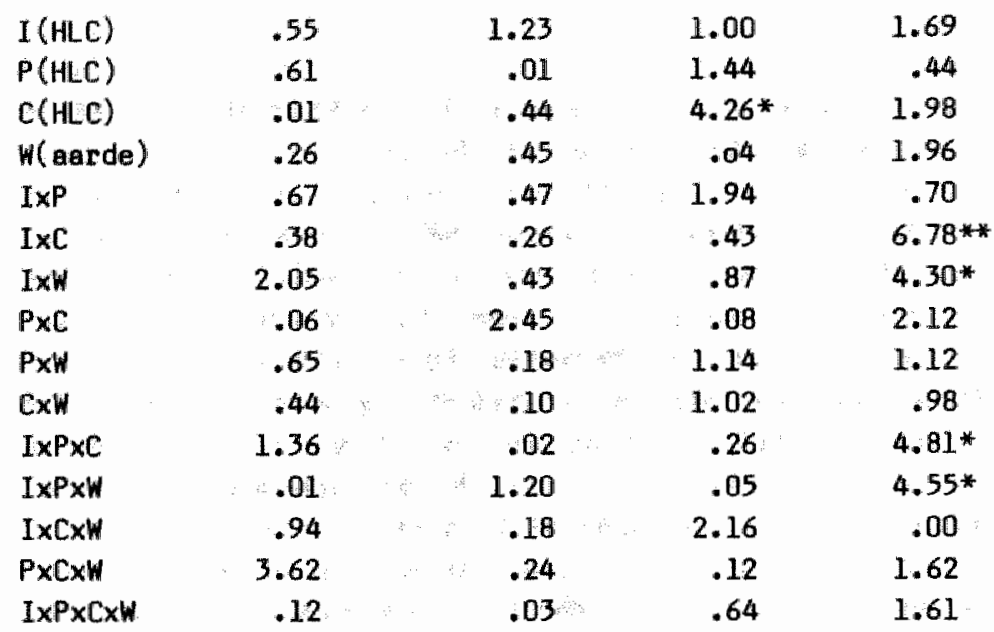

* p kleiner dan .05

* p kleiner dan .0l

(1) sociaal-economiache atatus en leeftijd als covariaten

(2) aexe en leeftijd als covariaten

(3) Bexe als covariaat

Samenvattend kunnen we zeggen dat bij de intentie tot lichaamsbeweging de interactle tussen de beheersingoorientatie en de waarde van gezondheld overeenkomt met de op basis van het model van Rotter verwachte interactie. Intern-georienteerden die gezondheld belangrijk vinden blijken vaker van plan te $z i j n$ geweest meer tijd an lichamsbeweging te besteden. Bij de andere afhankelijke variabelen $z i j n$ geen van de verwachte interacties significant.

In het deacriptieve gedeelte blljkt nag dat kans-georienteerden meer tijd aan lichaamsbeweging besteden, terwijl ook intern-georienteerden met een lage kans-orlentatie vaker van plan zijn geweest meer tijd aan lichaams- 
beweging te besteden. Aangezien onbekend is of zil ook daadwerkel ljk meer t1jd an lichaamsbeweging zijn gaan beateden, kan hier niets gezegd worden over de relatie intentie-gedrag.

\subsection{SAMENVATTING EN CONCLUSIE}

In dit hoofdstuk is de beheersingsorientatie bestudeerd vanult het model van Rotter. Volgens dit model mag verwacht worden dat vooral de interectie tussen de beheersingsorientatie en de warde van gezondheid samenhangt met (de intentie tot) ziekte- en gezondheidsgedrag, en wel zodanig dat intern- en arto-georienteerden, welke gezondheid belangrijk vinden, meer activiteiten andernemen voor hun gezondheid. In vrijwel geen van de analyses is een dergelijk verband angetroffen. De warde van gezondheid bleek soms wel, in interactie met de beheersingsorientatie, samen te hangen met het gedrag, maar veelal tegengesteld an de verwachttu richting. Wel bleken in een aantal gevallen de afzonderlijke beheersingsorientaties, al of niet in onderlinge interactie, en de afzonderlijke warde van gezondheid, samen te hangen met (de intentie tot) ziekte- en gezondheidogedreg.

Als belangrijkste bevindingen, na correctie op sexe, leeftijd, sociaaleconomische status en de gezondheidstoestand, kunnen worden genoemd:

- Arta-georienteerden zijn minder vaak van plan bij klachten omtrent hun gezondheid af te wachten, maer julist vaker van plan de dokter te raadplegen. Aangezien bij arts-georienteerden er een negatieve overeenkomst is tussen de intentie tot en het feitelijk bezoeken van de dokter, vinden we dit niet terug bij het feitelijke ziektegedrag.

- Degenen die gezondheld belangrijk vinden blijken meer andere activiteitien dan de arts bezoeken of medicijnen gebruiken ondernomen te hebben bl $\mathrm{J}$ klachten, dan degenen die gezondheid minder belangrijk vinden. Bij degenen die gezondheld belangrijk vinden $1 i j k t$ de overeenkomit tussen de intentie tot en het feitelijk ondernemen van andere activitititen ook groter den bij degenen die gezondheid minder belangrijk vinden.

- Kans-georienteerden raken vaker, en ondernemen vaker een mislukte stoppoging, dan de niet-kano-georienteerden.

- Van degenen die wel eens een poging ondernomen hebben om definitief te stoppen met het drinken van alcohol, blijken vooral de arta-georienteerden minder vaak een geslaagde poging te doen.

- Kans-georienteerden besteden meer tijd aan lichaamsbeweging. 
Uit het woorgaande is tevens af te leiden dat de beheersingsorientatie van inwloed is op de relatie intentie-gedrag. Vooral bij extern-georlenteerden blijkt deze relatle zwakker te $z \mathbb{1}$ jn. Zo blijkt deze relatle negatlef te $21 j \mathrm{j}$ b1j arta-georlenteerden wat het al of nlet bezoeken van de arts betreft, en blijken arts-georienteerden minder vaak een geslaagde poging te ondernemen on te stoppen met alcohol drinken. Hetzelfde geldt voor kans-georienteerden wat het stoppen met roken betreft.

Tot slot komt in dit hoofdatuk duidelijk naar voren dat de interacties tussen de beheersingsorientaties onderling vaak relevante informatie opleveren. Zo bleken vooral de arts-georienteerden die ook intern-georienteerd z1,jn; meer van plan te zijn de arts te raadplegen, terwijl de intern-georlenteerden die niet-arts-georienteerd $z 1 j n$, meer geneigd waren andere activiteiten te ondernemen. Op besis van de door ons verrichte analyses is echter moeilijk te achterhalen of er een consistent patroon in deze interacties zit. Andere analyses, zoals een vergelijking tussen alle mogelijke groepen (8) die op basis van de drie schalen te construeren $z \mathbb{1} j n$, kunnen hier meer inzicht in geven. 
HOOFDSTUK 9 DE BEHEERSINGSORIENTATIE BIMNEN HET MODEL VAN FISHBEIN EN AJZEN

In het voorgaande hoofdstuk hebben we de directe relatie behandeld tussen de beheersingsorientatie en de intentie tot gedrag en de beheersingsorientatie en het gerapporteerde gedrag. Verder is de invioed van de beheeraingsorientatie op de relatie intentie en gedrag aan de orde geweest. Nu zijn we toegekomen an de vraag of de beheersingoorlentatie van invloed is op de wijze warop de intentie tot stand komt. Deze vraag zal uitgewerkt worden aan de hand van het model van Fishbein en Ajzen voor zowel het rookgedrag als het alcoholgebruik.

In hoofdstuk 5 is gesteld dat de beheersingsorlentatie mogelijk van invloed is op de mate warin de attitude en de subjectieve norm (de gepercipieerde mening van anderen) de intentie beinvloeden. In dit hoofdstuk zullen we hierop ingaan. Verwacht wordt dat intern-georlienteerden hun intentle meer baseren op de attituden dan niet-intern-georienteerden, en dat arts-georienteerden hun intentie meer baseren op de subjectieve norm dan niet-arto-georienteerden.

\subsection{ROOKGEDRAG}

\subsubsection{HET MODEL}

In paragraaf 6.3 .6 is reeds begchreven op welke wijze de attitude, de subjectleve norm en de intentie gemeten is. Aangegeven is dat niet de directe maer de indirecte oubjectieve norm gebruikt zal worden.

In tabel 9.1 zijn de onderlinge relaties tussen de betreffende variabelen weergegeven.

Aangezien verwacht mag worden dat de attituden en subjectieve norm gedeeltelijk dezelfde variantie verklaren is een regressie-analyoe uitgevoerd met de intentie als afhankelijke variabele. Hieruit blijkt dat de indirecte subjectieve nom weinig extrals bijjdraagt aan de verklaring van de intentie (zie flguur 9.1; $R 2=.61$ ). De attitude verklaart reeda een groot deel van de variantle $(R 2=.60)$.

In figuur 9.1 is tevens de relatie tussen de intentie en het peitelijke rookgedrag (niet-wel roken) weergegeven. lit deze relatie blijkt dat de intentie en het gedrag wrijwel identiek zijn. Elders (Halfens e.a., 1984) is reeds beschreven dat het rookgedrag over een periode van 2 jaar erg stabiel is (kappa $=.80)$. 
Over een perlode van 1 maand - de periode warrover de intentie gaat - zal de atabiliteit nog groter zijn, zodat de hoge samenhang tuasen de inten tle en het gedrag een reele weergave vormt van deze samenhang.

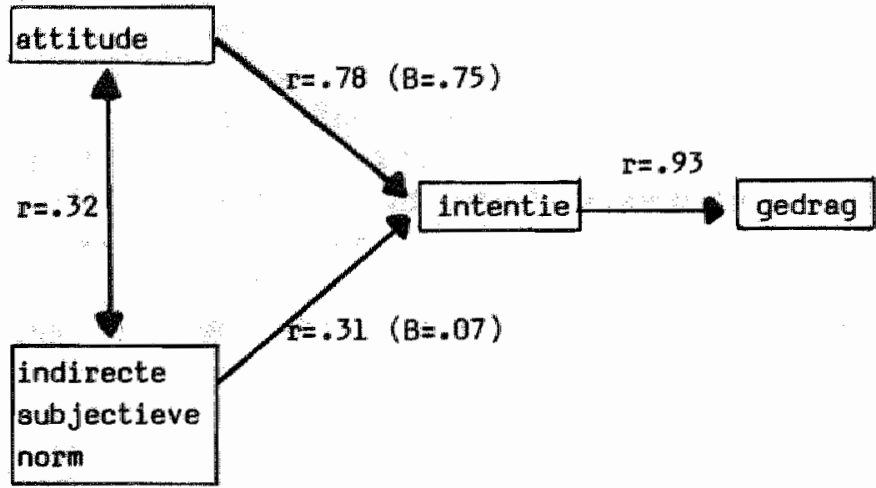

Flquur 9.1 Nulde-orde correlaties en Beta-coefficienten tussen de attitude, de indirecte subjectieve nom, de intentie ien het gerapporteerde rookgedrag $(n=710$; 1983 , alle coefficienten: $p$ is kleiner dan .01)

\subsubsection{DE BEHEERSINGSORIENTATIE BINNEN HET MODEL}

Behalve dat de beheersingsorientatie van invloed kan zijn op de mate waarin de attitude en de subjectieve norm met de intentie samenhangen, kan de beheersingsorientatie ook van invloed zijn op de attitude en de aubjectleve norm zelf, en daardoor de intentie beinvloeden. Dit is allereerst nagegaan (zie tabel 9.1).

Uit tabel 9.1 blijkt dat er een geringe samenhang 18 tussen de variabelen. Kang-georlenteerden blijken een lets positievere attitude en subjectieve norm ten canzien var roken te hebben, hetgeen ook in de intentie tot uitdrukking kont. Arts-georienteerden hebben alleen een iets hogere intentle tot roken.

Hieruit kunnen we concluderen dat de beheersingsarientatie nauwelijks de attitude en de subjectieve norm, en dus de intentie, beinvloedt. De indirecte subjectieve norn is ander anderen samengeateld op basis van de veronderatelde mening van de arts. Juist van arto-georienteerden zou men mogen verwachten dat deze zlch meer aantrekken van de mening van de arts. Aangezien de arts-orientatie niet samenhangt met de indirecte subjectieve norm $1 \mathrm{~s}$ ook de relatie tussen de arts-orientatie en de mate warin men de 
mening van de arts relevent vindt, berekend. Hierult blijkt dat arto-gearlenteerden zich inderdaad meer aantrekken van de mening van de arts (partiele correlatie is .17). Echter, aangezien de mate waerin men artsgeorienteerd is nauwelijks verachillen laat zlen omtrent de mate warin men denkt dat de erts positief staat ten opzichte van roken (partiele correlatie is -.07), is het uiteindelijk effect van de arts-orientatie op de indirecte aubjectieve norm met betrekking tot de arts gering (partiele correlatie: -.09 ).

Tabel 9.1 Nulde-orde en partiele correlaties (1) voor de samenhangen van de beheersingsorientatie met de intentie, de attitude en de subjectieve norm ten aanzien van roken $(n=710 ; 1983)$.

IHLC

PHLC

CHLC

intentie

$.03(-.01)$

$.04\left(.08^{*}\right)$

$.05(.09 *)$

attitude

$.01(-.01)$

$.03(.02)$

$.08 *(.06 *)$

indirecte aubjec-

tieve norm

$.03(.01) \quad-.04(-.04) \quad .08 *(.09 * *)$

(1) Partiele correlaties tussen haakjes:

- IHLC gecontroleerd voor leeftijd en sexe

- PHLC en CHLC gecontroleerd voor leeftijd en gociaal-economische status

* p kleiner dan .05

* p kleiner dan .01

Vervolgene is nagegaan of de beheeraingsorientatie van inwloed is op de mate warin de attitude en de subjectieve norm met de intentie amenhangen.

Hiervoor zijn de respondenten met behulp van de mediaan gesplitst in hoog- (+) en laegscoorders $(-)$ op de drie beheeraingsorientaties, en vervolgena is per groep een regressie-enalyse uitgevoerd met de intentie ala afhankelijk en de attitude en de indirecte subjectieve norm als onafhankelljke variabelen.

Uit tabel 9.2 blijkt dat er geen echte grote verschillen te zien zijn tusgen de hoog- en laagacoorders. Toch is er wel een duidelljke tendens 
waarneembaar. Bif de artg-georienteerden dragt de subjectieve norm ertoe bij de intentie te verklaren en is de Beta-coefficient hoger dan bij de niet-erts-georienteerden. Dit verschil 18 echter niet significant $(Z=$ .92). Aangezien het niet uitgeslaten is dat het gevonden verschil tussen arto en nilet-arts-georlenteerden vooral veroorzaakt wordt ondat de arts als relevante persoon is opgenomen in de subjectieve norm, is de analyge nogmaals uitgevoerd voor de arts en de niet-arts-georienteerden, maar nu zonder de arts als relevante persoon in de subjectieve norm. Deze bewerking levert nauwelijks verachillen op. Alleen de Beta voor de indirecte aubjectieve norm daalt bij de niet-artg-georienteerden tot .02. Bij de arto-georienteerden blijft deze Beta.11, zodat geconcludeerd mag worden dat het gevonden verschil niet veroorzaakt wordt doordat de arts als relevante persoon is opgenonen in de subjectieve norm.

Tabel 9.2 Beta-coefficienten en partiele correlaties(1) voor de relaties van de attitude en de indirecte subjectieve norm onderling en met de intentie ten aanzien van roken $(\mathrm{n}=710 ; 1983)$.

B

attitude $x$ intentie
$B$

indirecte subjectieve norm $x$ intentie $\mathbf{r}$

attitude $x$ indirecte subjectieve norn

\begin{tabular}{|c|c|c|c|c|}
\hline IHLC+ & $.73 * * *(.76 * * *)$ & $.06 \quad\left(.31^{* * *}\right)$ & $(.32 * * *)$ & $.58 * * *$ \\
\hline IHLC- & $.76^{* * *}\left(.79^{* * *}\right)$ & $.07 *(.34 * * *)$ & $\left(.32^{* * *}\right)$ & $.63 * * *$ \\
\hline PHLC+ & $.75 * *(.79 * * *)$ & $.11 * *\left(.38^{* * *}\right)$ & $(.33 * *)$ & $.64^{* * *}$ \\
\hline PHLE- & $.75 * * *(.77 * * *)$ & $.04 \quad\left(.28^{* * *}\right)$ & $(.30 * * *)$ & $.61 * * *$ \\
\hline $\mathrm{CHLC+}$ & $.74 * * *\left(.77^{* * *}\right)$ & $.07^{*}\left(.32^{* * *}\right)$ & $(.31 * * *)$ & $.62 * *$ \\
\hline CHLC- & $.76 * * *(.78 * * *)$ & $.06 \quad(.32 * * *)$ & $\left(.32^{* * *}\right)$ & $.63 * * *$ \\
\hline
\end{tabular}

(1) Partiele correlaties tusisen haakjes:

- IHAC gecontroleerd voor leeftijd en sexe

- PHLC en CHLC gecontroleerd voor leeftijd en sociaal-economische status

* pleiner dan .05

* p kleiner dan .01

*** pleiner dan .001 
Een probleen bij de voorgaande analyses vormt het feit dat de attituden en de aubjectieve norm onderling samenhengen (zie tabel 9.2). Dasi de intentie het sterkst samenhangt met de attitude, wordt het effect van de subjectieve norm woor een deel door de attitude uitgepartialiseerd, zodat het uiteindelijke effect van de subjectieve norm gering lijkt. De vraag 1s of dit julat is. Mede ondat het rookgedrag een stabiel gegeven 1s, mag aangenomen worden dat de samenhang tussen de attitude en de subjectieve norm vooral veroarzaakt wordt, doordat de attitude meer in overeenstenming gebracht is met het gedrag. De andere mogelijkheid, dus dat bijvoorbeeld niet-rokers hun partner en vrienden onder de niet-rokers kiezen, komt uiteraard ook voor, maar aangenomen mag worden dat dit effect minder sterk is. Voor collega"s en de arts lijkt dit bijvoorbeeld minder realiseerbar.

Dit betekent dat het geringe effect van de subjectieve norm warachijn$11 . j k$ een te lage schatting is. Dit probleem is juist relevant bij degenen die hun intentie (of gedrag) in eerste instantie baseerden op de aubjectieve norm. De gevonden tendens dat arts-georienteerden hun intentie meer op de subjectieve norm baseren dan de niet-artg-georienteerden, is dan ook in werkelijkheid warschijnlijk sterker.

Samenvattend kunnen we ult het voorgaande concluderen dat, wat het roken betreft, er een tendens is dat de mate waarin de attitude en de aubjectieve norm gerelateerd $z i j n$ aan de intentie, belinvloed wordt door de beheersingsorientatie. Arts-georienteerden lijken hun intentie meer op de mening van anderen te baseren dan de niet-arta-georienteerden.

\subsection{ALCOHOLGEBRUIK}

\subsubsection{HET MODEL}

In fIguur 9.2 ziljn de samenhangen tussen de attitudie, de subjectleve norm en de intentie ten anzien wan alcoholgebruik weergegeven.

Uit de nulde-orde correlaties blijkt dat de attitude sterk en de aubjectieve norm redilijk samenhangt met de intentie. Uit de regreasie-analyse met intentie als afhankelijke variabele blijkt echter dat ook bij het alcohol drinken de subjectieve norm, naast de attitude, weinig extra's bijdrasgt aan de verklaring van de intentie (zie fig. $9.2 ; R 2=.54$ ). De attitude alleen verkleart reeds $54 \%$ van de variantie.

Verder blijkt uit figuur 9.2 dat de intentie en het feltelijke gedrag minder sterk met elkaar samenhangen, dan bij thet roken het geval wes. 


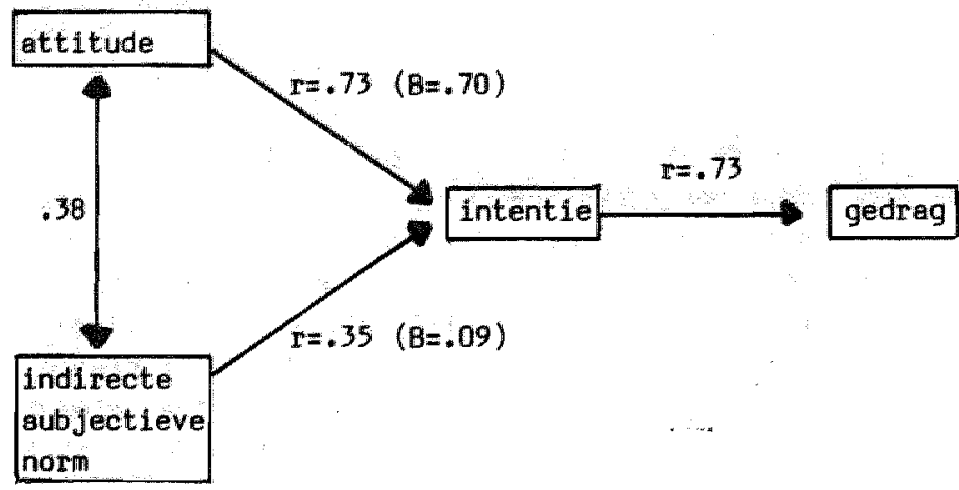

Figuur 9.2 Nulde-orde correlatiles en Beta-coefficienten tusgen de attitude, de indirecte gubjectieve norm, de intentie en het gerapporteerde drankgebruik ( $n=$ 481; 1983; alle coefflcienten: $p$ is kleiner dan $.01)$.

Aangezlen hierbij het gedrag gedefinieerd is als het al of niet wel eens alcohol drinken, is het aannemelijk dat niet alle respondenten, die zeggen wel eens alcohol te gebruiken, ook van plan zijn de komende maand alcohol te drinken.

\subsubsection{DE BEHEERSINGSORIENTIATIE BINNEN HET MODEL}

Allereerat lia nagegaan of de beheersingsorientatie samenhangt met de attitude, de aubjectieve norm en de intentie. Uit tabel 9.3 blijkt dat, na contrale op leeftijd en aciaal-economische status, alleen de attitude aamenhangt met de beheersingsorientatie. Nadere analyse leert dat dit verband voornamelijk veroorzaakt wordt doordat laagscoorders positiever ten opzichte van alcohol drinken ataan dan de overige respondenten. Laagacoorders kunnen opgevat worden als machtelozen, aangezilen zij geen of weinig beheersing toeachrijven aan zowel zichzelf als an externe factoren. Uit de gevonden relatle kan dan worden opgemaakt dat machtelozen poaitiever ataen ten opzichte van drankgebruik. 
Tabel 9.3 Nulde-orde en partiele correlaties(1) tussen de beheersingsorientatie en de intentie, de attitude en de indirecte subjectieve norm ten aenzien van alcohol drinken $(n=481 ; 1983)$.

IHLC

PHLC

CHLC

intentie

attitude

$\begin{aligned} .00(-.05) & -.12 * *(-.07) \\ -.07(-.10 *) & -.18 * * *(-.14 * *)\end{aligned}$

$-.07(-.04)$

indirecte

$-.12 *(-.10 *)$

subjectieve

norm

$-.04(-.06)-.11 *(-.07)$

$.01(.04)$

(1) Partiele correlaties tussen hakjjes:

- IHLC gecontroleerd voor leeftijd en geslacht

- PHLC gecontroleerd voor leeftijd en sociaal-economische status

* p kleiner dan .05

* p kleiner dan .01

*** p kleiner den .001

Evenals bij roken is bij de indirecte subjectleve norm het effect van de arta als relevente persoon nagegean. Dok hier blijken arta-georlenteerden meer belang te hechten aan de mening van de arta (partiele correlatie la .16), terwij1 de arts-georienteerden ieta meer dan de niet-arto-georienteerden, van mening $z 1 j n$ dat de arts het alcohol drinken negatief beoordeelt (pertiele correlatie is -.12 ). De uiteindelijke relatie tusen de arta-orientatie en de indirecte subjectleve norm met betrekking tot de arta is echter geringer $(-.09)$.

Uit het voorgaande kunnen we dus concluderen dat er alleen wat betreft de attitude een relatie met de beheersingsorientatie is gevonden. Machtelozen ataan iets positiever ten opzichte van drankgebruik.

Vervolgens is op identieke wijze als voor het roken nagegaen of de mate warin de attitude en de aubjectieve norm samenhangen met de intentie door de beheersingaorlentatle wordt beinvloed (zie tabil 9.4). 
Jabe1 9.4 Beta-coefficienten en partiele correlaties(1) voor de relaties wan de attitude en de indirecte aubjectieve norm onderling en met de intentle ten aanzien van alcohol drinken $(n=481 ; 1983)$.

\begin{tabular}{|c|c|c|c|c|}
\hline & $\begin{array}{l}\text { attitude } x \\
\text { intentie }\end{array}$ & $\begin{array}{l}\text { indirecte } \\
\text { subjectieve } \\
\text { norm } x \\
\text { intentie }\end{array}$ & $\begin{array}{l}\text { attitude } x \\
\text { indirecte } \\
\text { subjectieve } \\
\text { norm }\end{array}$ & $\mathrm{R} 2$ \\
\hline IHLC+ & $.68^{* * *}(.69 * * *)$ & $.05 \quad(.32 * * *)$ & $\left(.41^{* * *}\right)$ & $.50^{* * *}$ \\
\hline IHLC- & $.69 * *(.75 * * *)$ & $.13 * *(.39 * * *)$ & $(.37 * *)$ & $.60 * * *$ \\
\hline PHLC+ & $.66 * * *(.71 * * *)$ & $.13 * *(.39 * *)$ & $(.39 * * *)$ & $.52 * * *$ \\
\hline PHLC- & $.74 * * *(.75 * * *)$ & $.02 \quad\left(.29^{* * *}\right)$ & $(.36 * * *)$ & $.5 \mathrm{~B}^{* * *}$ \\
\hline CHLC+ & $.71^{* * *}\left(.72^{* *}\right)$ & $.004 \quad(.30 * * *)$ & $(.37 * * *)$ & $.53 * * *$ \\
\hline CHLC- & $.69^{* * *}\left(.74^{* * *}\right)$ & $.12 *(.41 * * *)$ & $(.42 * * *)$ & $.55 * * *$ \\
\hline
\end{tabular}

$\mathrm{R} 2$

(1) Partiele correlaties tusgen haakjes:

- PHLC gecontroleerd voor leeftijd en geslacht

- PHLC gecontroleerd voor leeftijd en soclaal-economische status

* pleiner dan .05

** p kleiner dan .01

*** p kleiner den 001

De gegevens wit tabe 19.4 wijzen in dezelfde richting als bij het roken. De attitude vormt ateeds de belangrijkste verklarende factor voor de intentie, terwijl bij de niet-intern-georienteerden en de arts-georienteerden, de indirecte aubjectieve norm ook bljdraagt aan de verklaring van de intentie. De arto-georienteerden en de nilet-intern-georienteerden baseren hun intentie dus mede op de mening van voor hun belangrijke anderen.

Het verschil in geta-coefficienten voor de subjectieve norm bij de artsen de niet-arts-georienteerden, evenals bij de intern- en niet-intern-georienteerden, blijkt echter niet algnificant te $z i j n(Z=$ resp. 1.18 en .90).

Wat de kans-georienteerden betreft, blijkt de relatie omgekeerd te zijn als bij het roken. Hier blijken juist de niet-kans-georienteerden hun in- 
tentle mede te beseren op de mening van anderen. Aangezien bij de artsorientatie wel de hoogscoorders hun intentie mede op basis van de mening van anderen bepalen, en de arts-orientatie en de kans-orientatie, zoals we eerder zagen, onderling samenhangen, zijn de analyses nogmaals ultgevoerd, maar nu voor vier afzonderlijke groepen, welke samengesteld zijn op basis van ến de arta-orientatie én de kans-orientatie.

In tabel 9.5 zijn de betreffende Beta-coefficienten en partiele correlatiles weergegeven.

Tabel 9.5 Beta-coefficienten en partiele correlatiea(1) voor de relaties van de attitude en de indirectie subjectieve norm onderling en met de intentie ten aanzien van alcohol drinken (1983).

$\begin{array}{lllll}\text { attitude } x & \text { indirecte } & \text { attitude } x & R 2 & n \\ \text { intentie } & \text { subjectieve } & \text { indirecte } \\ & \text { norm } x & \text { subjectieve } \\ & \text { intentie } & \text { norm } & \end{array}$

\begin{tabular}{|c|c|c|c|c|}
\hline HLC+ CHLC+ & $.66^{* * *\left(.69^{* * *}\right)}$ & $.08(.34 * * *)$ & $(.39 * * *)$ & $.48 * * *$ \\
\hline & $.66^{* * *}\left(.74^{* * *}\right)$ & $.18 *(.47 * * *)$ & $(.43 * *)$ & $.58 * * *$ \\
\hline & $.75 * * *(.78 * * *)$ & $-.00(.24 * *)$ & $(.32 * * *)$ & $.62 * * *$ \\
\hline & $.70^{* * *}\left(.72^{* * *}\right)$ & $.06\left(.35^{* * *}\right)$ & $(.42 * * *)$ & $.52 * * * 140$ \\
\hline
\end{tabular}

(1) Partiele correlatiea tussen hakjes (gecontroleerd voor leeftijd en social-economische atatus)

* p kleiner den .05

* p kleilner dian .01

*** p kleiner den .001

Ult deze tabel blijkt dat vooral de interactie tussen de arts- en de kans-orlentatie wan belang is. Door deze interactie worden in felte twee pure externe groepen samengesteld, namelifk de kans-georienteerden, die nliet-arta-georienteerd $z \mathbb{1 j n}(\mathrm{CHLC}+, \mathrm{PHLC}-$ ) en de arto-georienteerden, die niet kans-georlenteerd zijn (PHLC+, CHLC-). Nu blijkt uit tabel 9.5 dat bij de kans-georlenteerden de subjectieve norm niet van belang is voor de intentie, terwijl deze wel relevant is bij de pure arto-georienteerden. Met andere woorden, degenen die van mening zuj.jn dat vooral anderen - in dit geval de arts - hun gezondheid kumnen beheersen, bepalen hun intentie 
tot het al of nilet gebruiken van alcohol ook meer op basis wan de mening wan anderen. Het verschil tussen belde Beta-coefficienten bereikt aok hier echter niet het algnificantie-niveau $(Z=1.23)$. Evenals bij roken is deze analyse nognaala verricht, mar nu zonder de subjectieve norm met betrekking tot de arte. Dok nu vinden we vrijwel dezelfde resultaten. De Beta voor de subjectieve norm is bij de pure arts-georienteerden .16 en bij de pure kansmgeorienteerden .02. Rekening houdend met de opmerkingen die reeds bij het roken gemaakt $z i j n$, mag verwacht worden dat de gevonden verachillen in werkelij jkheid groter zijn.

Samenvattend kunnen we zeggen dat ook bij het alcoholgebruik er en tendene is dat de mate warin de attitude en de subjectieve norm gerelateerd zijn aan de lintentie varieert al naar gelang de beheersingsorientatie. Met name de echte arts-georienteerden lijken hun intentie meer op de aubjectleve norm te baseren dan de niet-arts-georienteerden.

\subsection{SAMENVATTING EN CONCLUSIE}

In dit hoofdstuk is het model van fishbein en Ajzen besproken voor het raken en voor het drinken van alcohol. Gebleken is dat woor beide gedragingen geldt dat de intentie het sterkst samenhangt met de attitude, terwijl de relatie tuseen de attitude en de intentie nauwelijks varieert naar gelang de beheersingsorientatie. Hoewel de subjectleve norm, naast de attitude, weinig extra bijdraagt in de verklaring van de intentie, is er wel een tendens dat de bijdrage van de subjectieve norm varieert naar de beheersingsorientatie. "Bij arts-georienteerden bleek" de subjectieve norm, naast de attitude, nog extra bij te dragen aen de verklaring van de intentle, hetgeen niet veroorzaakt wordt doordat een van de relevante perbonen warop de subjectieve norm gebaseerd is, de arts is. Bij de intentle tot alcohol drinken bleek verder dat de extra bijdrage van de subjectleve norm vooral gold voor de pure arts-georienteerden, dus de artsgeorienteerden die niet-kens-georlenteerd zijn. De verschilien tusgen de groepen bleken echter niet aignificant zodat feitelijk niet geconcludeerd mag worden dat arts-georlenteerden hun intentie meer baseren op de subjectieve norm den de niet-arta-georienteerden.

Aangezien voor belde intentlea geldt dat deze nauw samenhangen met het feltelljk gedrag en deze gedragingen over het algeneen vrijj stabiel zijn, mag verwacht worden dat in de loop der tijd de attitude aangepast is aan het gedrag, waardoor een sterkere relatie gevonden is tussen de attitude en de intentie, dan feltelijk bij de aanvang van het gedrag aanwezlg was. Dit betekent dat de mogelijke invloed van de subjectieve norm en het verschll daartussen bij de arts- en de niet-arts-georienteerden, wellicht aterker is dan uit onze gegevens naar voren komt.

Concluderend kunnen we dus zeggen dat er aanwijzingen zijn dat de arts- 
orientatie invloed heeft op de wijze warop de intentle tot stand komt. Arts-georienteerden lijken hun intentie meer op de subjectieve norm te baseren dan niet-arto-georienteerden. 


\subsection{SAMENVATTING VAN DE RESULTATEN}

In dit onderzoek is op verschillende wijzen nagegaan of de beheersingsorientatie relevant is voor ziekte- en gezondheidsgedrag. Hiervoor is een gezondheidsspecifieke beheersingsorientatie-lijst gebruikt, gericht op het meten van een drietal beheersingsorientaties, waruit de beheersingsorientatie blijkens de literatuur bestaat, namelijk een interne-, een arts- en een kans-orientatie. Factor-analyse op de totale lijst leverde inderdaad deze driedeling op, terwijl uit interne betrouwbarheidg-analyses bleek dat de drie schalen, gebaseerd op deze driedeling, een redelijk tot goede interne consistentie bezitten. De construct validiteit van de drie schalen bleek redelijk. Zo werd er een duidelijk en consistent verband gevonden met een algemene, niet-gezondheidsspecifieke, beheersingsorlentatie, ondanks het feit dat tussen de meting van de algemene en de gezondheidsspecifieke beheersingsorientatie een tijdsperiode van 2 jagr lag. Verder bleken de drie gezondheidsspecifieke orientaties redelijk samen te hangen met andere, nauw verwante, gezondheidsopvattingen, terwijl de beheersingsorientatie, geheel in overeenstemming met de literaturgegevens, samen bleek te hangen met de gezondheidstoestand. Degenen met een slechte gezondheidatoestand bleken meer arto- en minder intern-georienteerd te zijn dan degenen met een goede gezondheidstaestand.

Het merendeel van de eerder verrichte studies is uitgevoerd bij homogene populaties. Vandaar dat tevens is nagegaan of de beheersingsorientatie gerelateerd is an enkele demografiache kenmerken. Van deze kemmerken bleek leeftijd en sociaal-economische status en in mindere mate sexe met de beheersingsorientatie samen te hangen. Vrouwen en jongeren zijo lets meer intern-georienteerd, terwijl ouderen en degenen met een lagere soclaal-economische status meer arts- en kans-georienteerd zijn. Voor deze effecten is bij de analyses gecorrigeerd.

De eerste vraagstelling van deze studie kan dus als volgt beantwoord worden:

1. De beheersingsorientatie hangt samen met de subjectieve gezondheidstoestand en enkele demografische kenmerken, namelijk sexe, leeftijd en social-economigche status.

De relatie tussen de beheersingsorientatie en het ziekte- en gezondheidsgedrag is vanuit twee verklaringsmodellen van gedrag bestudeerd, namelijk vanuit het model van Rotter en vanuit het model van Fishbein en Ajzen. Op basis van het model van Rotter mocht verwacht worden dat niet de af- 
zonderlijke beheersingsorientaties samenhangen net zlekte- en gezondheldagedrag, maar dat juist de interacties tussen de beheersingsorientatiles en de warde van gezondheid samentiangen met zliekte- en gezondheidsgedrag. Pas als men de bekrachtiging, welke volgens het individu volgt op een bepaeld gedrag, belangrijk vindt, zal men genelgd zijn het betreffende gedrag uit te voeren. of het gedrag vervolgens ook daadwerkelijk vitgevoerd wordt is een andere zaak. Vandaar dat we een onderscheid genaakt hebben tussen de intentie tot en het feltelijke gedrag.

Uit de verrichte analyses blijkt dat vrijwel geen van de verwachte interacties aignificant semenhangen met de intentle tot of het gerapporteerde ziekte- en gezondheidsgedrag.

Wel zijn enkele interacties tussen de beheersingsorientaties en de warde van gezondheid significant, maar in tegengestelde richting. Zo blljken juist arts-georienteerden die de gezondheld minder belangrijk vinden, vaker van plan te zijn naar de arts te gaan, of andere activitelten te ondernemen. Dit zou op een consumptieve houding kunnen wijzen.

Verder blijken de afzonderlijke beheersingsorientaties, al of niet in onderlinge interactie, aamen te hangen met de intentie tot en het gerapporteerde ziekte- en gezondheidsgedrag. De belangr 1 jkste bevindingen hierbij ziju:

- Arte-georlenteerden zijn meer van plan de arts te raadplegen bij klachten, maar doen dit feitelijk nlet meer dan de niet-arto-georienteerden.

- Kans-georienteerden roken vaker (54\% versus 45\%) en indien ze een poging ondernemen on te stoppen met roken mislukt dit vaker (62\% veraus 50\%). Kans-georienteerden besteden echter meer tijd aan lichaamsbeweging.

- Van degenen die wel eens een poging doen on definitief te stoppen met het drinken van alcohol, blijken vooral de artg-georienteerden minder vaak een geslaagde poging gedean te hebben (53\% versus $78 \%$ ).

De tweede en de derde vraagatelling kunnen dus als volgt beantwoord worden:

2. De beheersingaorientatie hangt aamen met de intentie tat en het gerapporteerde zlekte- en gezondheldsgedrag.

Hierbij moet opgenerkt worden dat de gevonden verbanden, zeker voor het gezondheidagedrag, niet consistent zijn in de betekenis dat een bepalde orientatie wijst in de richting van gezonde den wel ongezonde gedragingen. Dit mag echter ook niet verwacht worden aengezlen in dit onderzoek ook bleek dat de diverse gezondheldsgedragingen nilet als cen gedragspatroon worden opgevat.

3. De warde van gezondheid is niet op de wijze, zoals volgens het madel van Rotter kan worden voorspeld, van Invloed op de samenhang tussen de 
beheersingsorientatic en de intentie tot en het gerapporteerde ziekteen gezondheldsgedrag.

In paragraaf 10.3 .1 zullen we hierop terugkomen.

De warde die men hecht an gezondheld blljkt wel als afzonderlijke varlabele aamen te hangen met zlekte- en gezondheidagedrag:

- Degenen die gezondheid belengrijk vinden blijken bij klachten meer andere activiteiten, zools extra rust in plaats van de arts bezoeken of medicijnen gebrulken, ondernomen te hebben dan degenen die gezondheid minder belangrijk vinden.

De vierde vraagatelling - Hangt de beheeraingsorientatie samen met een algemene maat voor gezondheldegedrag - kan niet beantwoordt worden; omdat met de ons beschikbare gegevens geen algemene mat voor gezondheidsgedrag geconstrueerd kon: worden.

Uit het voorgaande is tevens af te leiden dat de beheersingsorientatie van invloed $1 \mathrm{~s}$ op de relatie intentie-gedrag. Vooral bij extern-georienteerden is deze relatie zwakker. Zo blijkt de relatie intentie-gedrag minder sterk te zijn bij arta-georienteerden, wat het al of niet bezoeken van de arta betreft, terwijl arts-georienteerden ook minder vaak hun intentle om te stoppen met alcohol drinken onzetten in een daadwerkelijk stoppen. Hetzelfde geldt voor kans-georienteerden wat het stoppen met roken betreft.

De vijfde vraagstelling kan aldus als volgt beantwoord worden:

5. Een externe beheersingsorientatie heeft een negatieve invloed op de samenhang tussen de intentie tot en het gerapporteerde ziekte- en gezondhe ldagedrag.

Tot slot is an de hand van het model van Fishbein en Ajzen nagegaan of de beheersingsorientatie soms van invloed is op de wijze warop de intentile tat gedrag tot stand komt. Hoewel uit de verrichte analyaes ten aanzien van de intentie tot roken en alcohol drinken geen aignificante verachillen gevonden waren, bleek er wel een duidelijke tendens aanwezig:

- Arta-georienteerden, en met name arts-georienteerden die niet-kans-georlenteerd $z i \mathrm{jn}, 11 \mathrm{jken}$ hun intentie tot roken en alcohol drinken niet alleen te baseren op hun attitude ten opzichte van roken en alcohol drinken maar ook op basls van hetgeen anderen hierover denken.

Vraagatelling zes en zeven kunnen als volgt beentwoord worden:

6. De samenhang tussen de attitude en de intentie tot roken en alcoholgebrulk verschilt nauwelijks naar de beheersingsorientatie. 
7. De semenhang tussen de aubjectieve norm en de intentie tot roken en alcoholgebruik lijkt bij arto-georienteerden sterker den bij de nietertg-georienteerden.

Semengevat kunnen we zeggen dat een drietal schalen geconstrueerd konden worden welke de gezondheldsapecifieke beheersingsorientatie meten en welke redelijk valide zijn. Verder zijn de bellangrijkgte bevindingen wit deze atudie dat de beheersingsorientatie samenhangt met denografische kenmerken en gezondheldatoestand, en dat de beheersingsorientatie samenhangt met (de intentie tot) ziekte en gezondheidsgedrag. Bovendien zijn er aanwijzingen dat de beheersingsorientatie van invloed is op de wijze warap de intentle ten aanzien van alcohol drinken en wellicht ook ten aanzien van roken tot stand komt. Verder blijkt dat extern-georienteerden hun intentie minder vaak daadwerkelijk uitvoeren.

\subsection{METHODOLOGISCHE OPNERKINGEN}

Voor het onderzoek is gebruik gemaakt van de gegevens van een panelonderzoek near de subjectieve gezondheld, de gezondheidsopvattingen en de leefwijze van de Nederlandise bevolking. Een belangrijk argument am van deze gegevens gebruik te maken, was dat inzicht verkregen kon worden in de relatie tussen de beheersingsorientatie en demografische kenmerken. Verder bood deze onderzoeksopzet de mogelijkheid uitspraken te doen over de validiteit van de beheeraingsorientatie en, omdat er diverse zileteen gezondheidagedragingen gemeten worden, een algemeen beeld te krljgen over de relatie tussen de beheersingsorientatie en ziekte- en gezondheidsgedrag.

Als nadeel is reeds genoemd dat door de heterogene populatie de samenhangen wat minder aterk zijn, terwijl niet alle wenselijk geachte variabelen opgenomen konden worden. Een ander nadeel betreft het brede en retrospectieve karalkter van het onderzoek. Het brede karakter van het onderzoek, in de betekenis dat diverse gedragingen gemeten $z i j n$, biedt wel het vaordeel dat meer algemene uitapraken gedaan kunnen worden, maar heeft ala nadeel dat nlet in detail op de afzonderlijke gedregingen ingegaan kon worden. Doordat in dit onderzoek gevraagd werd naar beataand gedrag of naar gedragingen in het verleden hebben we tenminate bij de gezandheidegedragingen te maken met gedragingen die al langer beataan, of, in het geval van gedragsveranderingen, a langer geleden plaatavonden. De theorie van Rotter en van Fishbein en Ajzen hebben echter betrekking op het. tot stand komen van nieum gedrag, op de dynemiek van het gedrag. Dit heeft uiteraard consequenties gehad voor de gevonden relatles. Howel verwacht mag worden dat indien bijvoorbeeld intern-georienteerden meer 
geslaagde stoppogingen doen met roken, er ook meer ex-rokers intern-georienteerd $z i j n$, zal dit verband minder sterk zijn met deze onderzoeksopzet, ondat de beheeraingarientatie in de loop der tijd op basis van nieuwe ervaringen veranderd ken $z i j n$. Ook mag verwacht worden dat de oorspronkelljke reden warom men gestart ls met een bepasld gedrag, niet meer zllchtbaer is wanneer het gedrag eenmaal gestold ls tot een gewoonte. Het name bis het model van Fushbein en Ajzen heeft zich dit probleem voorgedaan. Doordat de Intentie nauw samenhing met het gedrag, en de attitude in de loop der tijd aangepast is aen dit gedrag, is de eventuele invloed van de aubjectieve norm op de intentie geminimaliseerd. On de exacte Invloed van de beheersingsorientatle op de manier warop de intentie tot atand komt te bepalen, is een andere onderzoeksopzet noodzake1ijk, of dient een minder atabiel gedrag gekozen te worden.

Samenvattend kunnen we zeggen dat door de breedte van het onderzoek een algemeen beeld verkregen is van de relaties tussen de beheersingsorientatie en het ziekte- en gezondheidagedrag, maer dat meer specifieke onderzoeken inzicht moeten geven in de "exacte" invloed van de beheersingsorientatie op het gedrag en gedragsveranderingen.

\subsection{THEORETISCHE OPMERKINGEN}

\subsubsection{HET MODEL VAN ROTTER}

Zoals we eerder gezien hebben bij het model van Rotter, is de beheerolngeorlentatie pae relevant indien or sprake is van een nieuwe of ambigue altuatie en indien de persoon in kwestie de bekrachtiging belangrijk vindt.

Aan de eerste conditle, een nieuwe of ambigue situatie, kon door onze keuze van onderzoeksopzet, niet voldaan worden. Gesteld is dat dit, voor wat de beheersingaorientatie betreft, minder relevant is narmate de beheersingoorientatle specifleker wordt geneten. of dit juist is en of de gevonden relatieg sterker zouden $z 1 j \mathrm{jn}$ in een nieuwe of ambigue aituatie, is met dit onderzoek niet te achterhalen.

Wel lifkt een nieuwe of anblgue aituatie relevant voor de warde van gezondheld. Afgezien van verschillende andere problemen met de warde van gezondheid, 11jkt het van belang te weten welke afweging een perroon makt op het moment dat hij of zij kieat voor een bepaeld gedrag. Deze afweging kan, indien het gedrag gestold is tot een gewoonte, heel anders zijn.

De was de van gezondheld is, onze bevindingen overziend, op geen enkele wijze overtuigend geweest als intermedierende variabele. Hoewel de waarde van gezondheid soms relevant was, bleek deze veelal in omgekeerde rich- 
ting van beleng. Zo bleken juist de arts-georlenteerden die gezondheld inder belangrijk vanden, neer de intentie te hebben de arts te raadplegen. In een enkele analyse bleek de waerde van gezondheid als af zonderiljke varlabele relevant. Degene die gezondheid belangrijk vonden, ondernamen bij klachten meer andere activitelten, zoals extra rust nemen.

Ondanks dat geen rekening gehouden is met de els dat de situatie nieuw of ambigue moet zijn, zijn er toch ook andere redenen aan te wijzen, waram de warde van gezondheld nilet voldaan heeft. Een van deze redenen ls de operationaliaering van de waarde van gezondheid. Uit eerdere analyses met de respondenten uit het panelonderzoek (Halfens e.a., 1984) is gebleken dat al naar gelang de vraagstelling, de mate waarin men gezondheid belangrijk vindt varieert. Zo is $92 \%$ wan de respondenten het eens met de uitspraak "gezondheid is het allerbelangrijkste in het leven van een mens". In gchrille tegenstelling hiermee is de bevinding dat slechts 5\% het gezin minder belangrijkk vindt dan de gezondheid. In dit onderzoek is gekozen voor de afweging die men makt tusaen gezondheid en andere relevante zaken. Nifet alleen ondat de antwoorden op deze afwegling beter verdeeld waren dan de antwoorden op de andere indicatoren van de waarde van gezondheid, maar ook ondat het belang dat men hecht aan een bekrachtiging, Juist een afweging vormt met het bellang dat men hecht aan andere bekrachtigingen. Geen gegevens zijn echter bekend over de validiteit van deze scharl. Het feit dat de antwoorden verschillen al naergelang de vraagatelling, maakt dat het zinvol is na te gaan in hoeverre de door ons gebruikte schaal inderdaad valide is om ne te gaan in welke mate mensen gezondheid belangrijk vinden.

Daarnasst kunnen we ons afvragen of met deze afweging het beloningsaspect van de bekrachtiging gemeten wordt. Degene die gezondheid belangri,jk vindt en bijwoorbeeld van mening is dat lichsemsbeweging de gezondheld positief beinvloedt, kan er toch voor kiezen meer aandacht aan het gezin te beateden, aangezlen hif of zij het netto-effect van lichaamabeweging op de gezondheid lager inschat, dan het netto-effect dat "meer aandacht aan 21 Jn gezin" oplevert. Met name in dergelijke gevallen zal het van belang zijn de bekrachtigingawaerde te meten op het moment dat de persoon voor deze keuze stat.

Een ander punt dat betrekking heeft op de waarde van gezondheld is de betekenis van de term gezondheid. Uit diverse onderzoeken blijkt dat de term gezondheld voor mengen verschillende betekenissen kan hebben, zoals het afwezig zijn van ziekte, fit voelen on voldoende reserve hebben (Herzlich, 1973; H1111ams, 1983; D"Houtaud en Fleld, 1984). Het is dan ook niet ultgesloten dat versehillen in de warde van gezondheid toegeachreven moeten worden aan verschillen in de betekenis ven gezondheld. Tot slot is het nilet uitgesloten dat voor de respondenten de bekrachtiging van de onderzochte gedragingen niet gezondheld la, maar lets anders. Het feit dat geen schali geconstrueerd kon worden voor de gezondheldagedragingen wijst in deze richting. Bovendien speelt in deze kweatle een rol dat op een bepaald gedrag meestal niet één maar meerdere bekrachit- 
gingen volgen, welke tegengeatelde effecten kunnen hebben. Stoppen met roken kan bepaalde ziektes woorkomen, mear kan zeker in het begin leiden tot negatieve sensaties. Van belang is te echterhalen wat volgens de persoon zelf de belangrijkkate bekrachtigingen zijn.

Dit betekent dat ultgebreider gevraagd zou moeten worden near mogelijkce bekrachtlgingen. Echter door alle mogeliflke bekrachtigingen en de warde die men hieraan hecht, te onderzoeken, wordt in feite de attitude ten opzichte van thet betreffende gedrag, zoals Fishbein en Ajzen deze definieren, gemeten. Hiemee wordt tegelijkertijd duldelijk dat met het model van Rotter alechta een bepaalde deterninant van gedrag gemeten wordt. Naar de mening van de ongeving wordt nlet expliciet gevraagd. Aangezien uit dit onderzoek duidelijke aanwijzingen naar voren gekomen zij.jn dat juist extern-georienteerden ap zijn mingt hun intentie tot gedrag ook baBeren op de mening van hun amgeving, kan hieruit geconcludeerd worden dat Rotter"s model beperkt is tot intern-georienteerden. Dit komt ook overeen met. Rotter's idee dat juist en interne arientatie in combinatie met de waarde van de bekrachtiging leidt tot gedrag. Het feit dat extern-geoxienteerden ook tot dit gedrag kunnen komen, mar meer op basis van de mening van hun ongeving wordt hlerdoor geheel verwaarloosd. Vandaar dat. voor de bestudering van de beheersingsorientatie het model wan fishbein en Ajzen meer geëigend is.

Samenvattend kunnen we zeggen dat met onze onderzoeksopzet geen recht is gedaen an het model van Rotter, inzoverre geen rekening is gehouden met. de els dat de sltuatie nieuw of ambigue moet zijn. Verder zijn diverse andere redenen genoend wearom de operationalisatie van de bekrachtigingswaarde (de warde van gezond) niet voldeed, bijwoorbeeld omdat de beloningswaarde niet in deze operationalisatile tot uitdrukking kont en omdat gezondheld niet de enige reden lo warom men tot bepaalde ziekte- en gezondheidsgedragingen komt.

Aangezien bij het model van Flshbein en Ajzen niet alleen rekening gehouden wordt met meerdere bekrachtigingen, maar ook met het effect van de mening van anderen, 1 g gesteld dat de beheeraingoorientatie beter binnen het model van Fiahbein en Ajzen bestudeerd kan worden.

\subsubsection{DE BEHEERSINGSORIENTATIE}

Op basis van onze onderzoeksgegevena hebben we geconcludeerd dat de beheeralingaorientatie gerelateerd is an ziekte- en gezondheidsgedrag. Echter, conform de literatuur, zijn de samenhangen op een enkele uitzondering na nooit echt aterk en wijzen ze niet in één bepaalde richting. Het onderscheid tussen de intentie tot en het feitelijk gedrag lijkt in dit verband vruchtbaarder. Met neme bij ziektegedrag is er een duidelijke relatie met de intentie, hoewel opgemerkt moet worden, dat dit ten dele ook 
toegeschreven kan worden aan het feit dat de intentie tot ziektegedrag en de beheersingarientatie op een gelijk niveau van specificitelt gemeten zijn. Verder zijn er eanwijzingen dat de beheeraingoorientatie van invloed is op het daadwerkelijk uitvoeren van de intentie, en op de wijzen warop de intentie tot stand komt. Met name deze laatate twee bevindingen, dus dat de beheersingsorientatie van invloed kan zijn op de wijze warrop de intentie tot stand komt en op het daadwerkelijk uitvoeren van deze intentie, verdienen bij de bestudering van de beheersingsorientatie meer aandacht. Met dit onderzoek lo hiertoe een eerste aanzet gegeven, ook al was de door ons gebruikte opzet hiervoor minder geachikt. Een (quasi-) experimentele opzet kan hierover meer uitsluitsel geven.

Een ander punt dat betrekking heeft op de multi-dimensionalitelt van de beheersingoorientatle, betreft de interpretatie van een lage score op de achalen. Bij een interne orientatie kunnen we ons liets voorstellen, bij een niet-interne orientatie wordt dit moelijijker. Een niet-interne-orientatie wordt eigenlijk pas zinvol in combinatie met een andere scheal. Bijvoorbeeld een hoge arto-orientatie en een lage interne-orientatie duidt op een pure arta-orientatie. Uit de variantie-analyse is gebleken dat interacties tussen de beheersingsorientaties vaak samenhingen met de intentie of het gerapporteerde gedrag. Niet alleen de afzonderlijke orientaties bleken van belang, maar juist ook de onderlinge combinaties. Met uitzondering van Wellston en Wallston (1982) wordt hierover in de $11-$ teratuur geen melding gemaakt, hetgeen verklaard kan worden doordat nauwelljks gebruik wordt gemaakt van variantleanalyse. Dit duidt erop dat, nu gekozen is voor een multi-dimensionasi concept, een nieuwe typologle ontworpen moet worden. Juist omdat gezondheid vaak niet gezien wordt als beheerst door slechts eén instantie, ls het van belang in plaats van met de afzonderlijke achalen verder te werken, over te atappen naar een typologie van de beheersingsorientatie.

In dit onderzoek zijn verschillende subgroepen vaker voorgekomen, zoals intern-georienteerden, die ook arts-georienteerd $z \mathbb{1 j n}$, of arts-georienteerden die niet-kane-georienteerd zijn. Mede doordat zowel tweeweg-interacties als drieweg-interacties significant bleken, zljn een groot aantal varianten mogelljk. Deze zullen beperkt moeten worden tot een aantal veel voorkomende combinaties, welke relevante verschillen ten aanzien van zlekte- en gezondheidagedrag laten zien. Op basis van dit onderizoek lo deze keuze moeilijk te maken, mede doordat soms tweeweg- en ams drieweginteracties significant waren. Hiervoor zijn nieuwe analyses naodzake1ijk, warbij verschillen tussen de acht, op basis van de drie schalen verkregen, subgroepen bestudeerd kunnen worden. Op ba:is van dit onderzoek beperken we one dus tot de conclusie dat de dile geconstrueerde schalen alechts een tussenstation vornen in de operationalisatie van de beheersingsorientatie.

Tot slot een laatste opmerking over de gezondheidsspecifieke beheersingoorlentatie. In de vorige paragraaf zijn grote vraagtekens geateld bij de impliciete veronderstelling dat gezondheid de belangrijkste bekrachtiging 
18 bis gezondheidagedrag. Indien dit julst is, resteert de vraag of een gezondheldaspecifieke beheersingsorientetie wel zinvoller is dan een algemene beheersingsorlentatie, aangezien bij de gezondheidsepecifieke beheeraingeorientatle er impliciet vanult gegaan wordt dat gezondheid opgevat wordt als de bekrachtiging van het onderzachte gedrag.

\subsubsection{HET MODEL VAN FISHBEIN EN AJZEN}

Het gebruik wan het model wan Fishbein en Ajzen in dit onderzoek is vruchtbaar gebleken. Uit het onderzoek is, hoewel niet significant, een tendene naar voren gekomen dat met name de arts-arientatie van invloed is op de determinanten die de intentie bepalen.

Een terugkerend probleem in dit onderzoek, is het feit dat stabiele gedragingen gemeten zljn. Hierdoor was de samenhang tussen de intentie en het gedrag hoog. Aangezien aengenomen mag worden dat de personen hun attitude in de loop der tijd hebben angepast aan hun gedrag, 11jkt het alsof de intentie voornamelijk gebaseerd is op de attitude.

Dit probleem zou zich nlet hebben voorgedaan als we de analyses uitsluitend voor de rokers (of de alcohol-gebruikers) uitgevoerd zouden hebben. Aangezien, gegeven de hoge samenhang tussen de intentie en het gedrag, de intentie in dat geval een zeer geringe variantie zou vertionen, zijn deze analyses weinig zinvol. Deze analyses waren warschijnlijk wel zinvol geweest als niet was gevraagd naar het gedrag, maar nar een verandering in gedrag, zoals atoppen met roken. Verwacht mag worden dat de betreffende variabelen uit het model dan meer variantie bij de rokers zouden vertonen.

Meer duidelijkheid mag te verwachten geweest als we ons gericht hadden op minder gtablele gedragingen. In die gevallen mag ook verwacht worden dat de amenhang van de aubjectieve norm met de intentie groter is dan de, voor dit model, lage samenhang die wij vonden.

Het geringe verschil tussen de variabelen die betrekking hadden op het roken (alcohol-drinken) en de variabelen die betrekking hadden op het nlet-roken (geen alcohol drinken) moet waerschijnlijk ook verklaard worden uit het feit dat gevraagd is near gtabielle gedragingen. Juist omdat deze variabelen betrekking hebben op reeds anwezig gedrag, leveren de verschillen weinig extra informatie op.

Tot slot kan nog opgenerkt worden dat de directe subjectieve norm minder sterk gamenhing met de intentie dan de indirecte subjectieve norm. We1licht dat met de directe aubjectleve norm naar een te algemene mening wordt gevraagd, en dat het beter is de indirecte subjectieve norm als indicatior te gebruiken.

Concluderend kunnen we zeggen dat het model van Fishbein en Ajzen niet geheel tot $z i j n$ recht is gekomen, doordat gebruik is gemakt van stabiele 
gedragingen. Verwacht meg worden dat ook de rol van de beheersingsorlentatle binnen het model duidelijker naar voren kont bij instablele gedragingen of bij gedregsveranderingen.

\subsection{PRACTISCHE CONSEQUENTIES}

Hoewel uit het onderzoek gebleken is dat de beheiersingsorientatie relevant is voor gezondheids- en ziektegedrag, zijn de resultaten nog nilet van dien aard, dat hieruit nu al duldelijk praktiache toepassingen zijn af te leiden. Toch kan, rekening houdend met eerdere bevindingen, een enkele opmerking gemaakt worden.

In het literatuuroverzicht hebben we al herhaaldelijk geconstateerd det voor intern- en extern-georienteerden met succes verschillende interventie-technileken gehanteerd worden. Dinze bevinding dat er een tendens la dat de arto-orientatie van invloed is op de wijze warop respondenten hun intentie bepalen, is hiermee in overeenstemming. Aangezien de attitude gebaseerd is op enerzijds de verwachte consequenties van gedrag en anderzijds de evaluaties van deze consequenties, en verwacht mag worden dat juist de attitude voor intern-georienteerden van belang is, betekent dit dat bij een meer intern-georienteerde doelgroep de nadruk bij voorlichting op de consequenties en hun evaluaties moet liggen.

Bij de arto-georienteerden daarentegen 18 warschijnlijk de mening van de amgeving van meer belang. De voorbeeld-functie van relevante anderen lijkt bij deze doelgroep belangrijker. Beekers (1982) noemt enkele kerr merken waaraan een model moet voldoen, zoals een indruk van deskundigheid, een hogere status, maar ook moet het model overeenkomaten vertanen met de doelgroep. Dit zou betekenen dat ten aanzien van het meer externgeorlenteerde doelgroepen van belang is relevante personen uit de doelgroep als voorbeeld te laten fungeren. In de reclame wordt deze methode vaak gebruikt. Niet zozeer de informatie over het product zelf is belangrijk, maar de persoon die de informatie verschaft.

Echter, alvorens tot meer definitieve uitspraken te komen over het bovenstaende is het gewenst eerst verder onderzoek te doen.

\subsection{VERDER ONDERZOEK}

In het voorgaande zijn reeds enkele aanbevelingen gedaen voor verder onderzoek. Uit deze studie zijn diverse relevante onderzoekswooratellen te destilleren, zoals over de validiteit van de waarde van gezondheid. Hier willen we ons echter beperken tot de ons inzlens belangrijkate twee punten ten aanzien van de beheersingsorientatie, die zich bij voorkeur lenen voor verdere enalyse. 
Allereerst is het ven beleng de operationelisatie van de beheersingsorlentatie verder wit te werken near een typologie, waarbij] we in het midden laten of dit een gezondheidsspecifleke of een algemene typologie van beheerisingoorientatile moet worden.

Vervolgena ia relevent na te gaan op welke wijzen de beheersingsorientatie vooral effect kan hebben op het uiteindelijke gedrag. Een tweetal wijzen kunnen hiervoor aangegeven worden. Ten eerste op welke wijze de intentie tot atand komt en ten tweede in welke mate de intentie daadwerkelijkk angezet wordt in gedrag. Daarnaast kan de beheersingaorientatie aanenhangen met de attltude en de subjectieve norm.

Vooral het model ven Fiahbein en Ajzen lijkt het aangewezen kader warbinnen het onderzoek kan plaatsvinden. Met dit model kan inzicht verkregen worden omtrent de determinanten die bij de vergchillende typen van beheersingsorientatie van belang zijn voor de intentie en bij welke typen de relatie tussen de intentie en het gedrag sterker is. Hierbij is van belang dat het onderzoek uitgevoerd wordt voor instabiel gedrag, dan wel voor gedragaveranderingen, wabrvan verwacht mag worden dat ook de subjectleve norm een redeligke invloed heeft op de intentie.

Samenvattend kunnen we zeggen dat twee onderzoeken nu zinvol zijn, name$11 \mathrm{Jk}$ een onderzoek naer de verdere operationalisering van de beheersingsorlentatle in een typologie, en een onderzoek warin, nauwkeuriger dan in ons onderzoek, wordt nagegaan of de beheersingsorientatie samenhangt met de wijze waerop de intentie tot stand kont, en met de mate waarin de intentie daadwerkelijk wordt uitgevoerd. 
SAMENYATIING

Mensen hebben verschillende opvattingen over de oorzaken van zlekten en over datgene wat $z 1 j$ zelf al dan niet kunnen doen om beter te worden. Sommigen menen dat een goede gezondheid vooral een kwestie la van geluk. Anderen menen dat men er zelf veel aan kan doen om gezond te blijwen of beter te worden. Voor een derde groep is het vooral de arts in wie men zijn vertrouwen stelt voor het behoud van zijn gezondheid. Deze opvattingen noent men beheersingsorlentaties. In deze studie wordt onderzocht hoe zij met verschillende vormen van ziekte- en gezondheidsgedrag samenhangen.

In hoofdstuk 2 wordt ingegaan op de definlering van de beheersingsorlentatle. Mede op basis van de sociale leertheorle van Rotter, waruit het concept oorspronkelijk naar voren is gekomen, is de beheeraingsorientatie omschreven als de algemene verwachting van een individu, door wie of wat de gevolgen van zijn of haar gedrag beheerst worden en in welke mate. Een onderacheid is gemakt tussen de beheersingsorlentatie en enkele andere concepten, zoals "self-efficacy", "outcome-expectations", "locus of causality" en machtelooaheid. Uitvoerig is ingegaan op het onderacheid met machteloosheid. Vaak wordt machteloosheid als synoniem gebrulkt voor een externe beheersingsorientatie, dat is de orientatie dat de gevolgen van gedrag niet door de peraoon zelf beheerst worden, maar door externe factoren, zoals de arts of kans en geluk. De opvatting dat vooral externe factoren gevolgen of gebeurtenissen beheersen, zegt echter niets over de mate waarin men dit onaanvaardbar vindt. Van machteloosheid kan pas in dit kader gesproken worden indien het individu de beheersing door externe factoren onasnvaardbaar vindt.

Verder is ut diverse studles gebleken dat het zinval lo de beheersingom orientatie te onderscheiden naar verschillende factoren. Zo moet men een onderscheid maken naar de verschillende instanties, die gevolgen van gedrag kunnen beheersen, zaals de persoon zelf, de arte of kana en geluk. ook kan men de gevolgen onderscheiden, namelijk naar de inhoud, die bijvoorbeeld betrekking kan hebben op gezondheld of op politieke gebeurtenissen, en naar de aard die positief of negatlef kan zljn.

In hoofdatuk 3 zijn aan de hand van deze vier factoren enkele keuzemonenten en criteria geformuleerd voor het meten van de beheersingsorientatie. Het name het onderscheid in verschillende beheersende inatantles is hierbij van belang, aangezien gebleken is dat de interne en de externe orientaties onafhankelijk van elkaar zijn. Vier Engelgtalige meetinstrumenten 
zijin in dit hoofdatuk aan de hand van deze criteria besproken. Ceconcludeerd is dat de Én-dimenalonale meetinstrumenten, waaronder de door Rotter geconatrueerde yragenlijst, minder bruikbaar $21 . j n$.

Wa deze bespreking van de beheersingsorientatie is ingegaan op de relatie tuasen de beheersingsorientatie en ziekte- en gezondheidsgedrag. Uit hoofdgtuk 4 blijkt dat onderzoek omtrent deze relatie nog weinig samenhang vertoont, Vaak gaat het on incidentele onderzoeken waarbij nauwelijks rekening gehouden: wordt met mogelijke intervenierende factoren, zoals leeftijd en sociaal-economische status, en met de voorwariden die volgen ult de sociale leertheorie. Volgens deze theorie heeft de beheeringsorientatie pas invloed als het individu het gevolg van het gedrag belangrijk vindt en de situatle nieuw of ambigue is.

Uit de literatuur blijkt dat er nauwelijks directe samenhangen gevonden worden tussen de beheersingsorientatie en ziekte- en gezondheidsgedrag. Wel zijn er aanwijzingen dat intern-georienteerden meer baat hebben bij interventie-programma's welke congruent $21 \mathrm{jn}$ met een interne orientatie, terwijl voor extern-georienteerden juist programa's zinvol zijn welke congruent zijn met een externe orientatie.

In hoofdstuk 5 zijn vervolgeng mede op basis van de sociale leertheorie van Rotter en het verklaringsmodel van Fishbein en Ajzen, een aantal vraagatellingen geformuleerd.

In hoofdstuk 6 is beschreven hoe het onderzoek onderdeel vormt van een panelanderzoek naar de leefwijze en de subjectieve gezondheid van de Nederlandse bevolking in de leeftijdsklasse 20 tot 65 jaar. Voor dit panelonderzoek, warvoor zowel in 1981 als in 1983 een meting is verricht, is gebruik gemaakt van een geatandaardiseerde vragenlijst. Uit het panel ( $n$ - 892) zijn de respondenten met een chronische aandoening, waarvoor ze onder behandeling waren, en de respondenten bij wile een antwoordtendentile op de beheeraingeorientatie-vragenlijst werd aangetroffen, voor dit onderzoek verwijderd. De analyses zijn uiteindelijk verricht op 710 personen.

In hoofdatuk 7 is de operationalisatie van de beheersingsorientatie beachreven. Als meetinstrument is een gezondheidsapecifieke beheersingsorlentatie-lijst gebruikt, welke volgens de literatuur een drietal afzonderlijke beheeraingsorientaties bevat, namelijk een interne-, een artsen een kanomorientatie. De betroumbaarheid en de validiteit van deze drie schalen bleek redelijk. In overeensteming met de literatuur, bleek de beheersingsorientatie samen te hangen met de gezondheidstoestand. Degenen met een slechte gezondheidatoestand bleken meer arts en minder interngeorienteerd te zijn dan degenen met een goede gezondheidstoestand. Verder bleek dat de beheersingsorientatie samenhing met enkele demografische kenmerken, namelijk leeftijd, sociaal-economische status en in mindere 
mate sexe. Vrouwen en jongeren zijn iets meer intern-georlenteerd, terwij1 ouderen en personen met een lagere socilal-economische status meer arto- en kans-georienteerd zijn. Noor deze effecten is bij de analysis gecorrigeerd.

De relatie tussen de beheersingeorientatie ien thet zlekte- en gezondheidsgedrag is aan de hand van een tweetal verklaringmodellen van gedrag beatudeerd, namelijk aan de hand van het model van Rotter en aan de hand ven het model van Fishbein en Ajzen.

In hoofdatuk is de beheersingsorientatie vanuit het model van Rotter bestudeerd. Volgens het model van Rotter heeft de beheeroingsorlientatie een directe invloed op het gedrag, mits het individu de bekrachtiging in dit geval gezondheid - belangrijk vindt, en de situatie nieum of ambique is. Op besis van het model van Rotter mag zodoende verwacht worden dat niet de afzonderlijke beheersingsorientaties samenhangen met het zlekte- en gezondheidsgedrag, maar juist de interactie tusaen de beheersingeorlentatie en de waarde van gezondheid. Pas als men de bekrachtiging welke volgens het individu volgt op een bepaald gedrag, belangrijk vindt, zal men genelgd zijn het betreffende gedrag wit te voeren. of het gedrag vervolgens ook daadwerkelijk uitgevoerd wordt is een andere zaak. Vandaar dat we oak een onderscheld gemaakt hebben tussen de intentle tot en het felteli.jke gedrag.

Uit de verrichte analyses blijkt dat vrijwel geen van de verwachte interacties significant samenhangen met de intentie tot of het gerapporteerde zlekte- en gezondheidsgedrag. Wel hangt de afzonderlijke beheersingoorientatie in sommige gevallen samen met de intentlie tot en het gerapporteerde ziekte- en gezondheidsgedrag. Zo blijken arta-georienteerden vaker van plan de arts te raadplegen bij klachten en ondernemen zij minder vaak een succesvolle poging tot stoppen met alcohol drinken. Kans-georienteerden blijken vaker te roken en ook minder succesvol te zijn bij het stoppen met roken. $Z i j$ doen dearentegen we 1 meer aan licheamsbeweging.

De beheersingsorientatie blijkt ook enigszins van invloed op de relatie intentie en gedrag. Zo blijkt deze relatie minder aterk te $z^{1} j$ in bij artsgeorienteerden wat het al of niet bezoeken van de arts betreft, mislukt hun poging on daadwerkelijk te stoppen met alcohol drinken vaker. Hetzelfde geldt voor kans-georienteerden ten aanzien van het atoppen met roken.

Tot alot is in hoofdstuk, 9 an de hand van het model van Fishbein en $\mathrm{Aj-}$ zen nagegaen of de beheersingsorientatie van invloed 18 op de wijze warop de intentile tot gedrag tot stand komt. Volgens het model van Fiahbein en Ajzen kont de intentie tot gedrag tot stand op basis van de attitude ten opzichte van dat gedrag en op basis van hetgeen relevante anderen van dat gedrag vinden. Verwacht werd dat intern-georienteerclen hun intentie meer bepalen op basis van de attitude dan de niet-intern-georienteerden, 
terwij1 de arts-georlenteerden hun gedrag meer dan de niet-arts-georienteerden baseren op hetgeen anderen van dat gedrag vinden. Hoewel uit de verrichte analyoes ten aanzien ven de intentle tot roken en alcohol arirken geen significante verachillen gewonden werden, bleek er wel een duldel1jke tendens dat arts-georlenteerden en met name arto-georienteerden die niet-kans-georienteerd zlin hun intentie tot roken en alcohol drinken nilet alleen baseren op hun attituden mar ook op hetgeen relevante anderen over roken en drinken denken.

Aangezien uit de analyses bleek dat diverse interacties tussen de drie beheersingsorientatie-schalen vaak samenhingen met (de intentie tot) ziekte- en gezondheidagedrag, is in hoofdstuk 10 gesteld dat het wellicht zinvoller 18 on de verbanden tuasen het gezondheidsgedrag en de beheeralngsorientatie niet zozeer te benederen vanuit het trekmodel waarin hoog- en lasgacoorders op een van de drie orientaties met elkaar vergeleken worden, maar vanult een typologile warin bijvoorbeeld hoog intern- en hoog arts-georienteerden vergeleken worden met hen die hoog intern- en Laag arto-georlenteerd zijn.

De tweede conclusile uit dit onderzoek is dat de relatie tussen beheersingsorlentaties en gezondheidsgedrag beter vanuit het model van fishbein en Ajzen beatudeerd kan worden dan vanult het model van Rotter, vooral ondat in dit laatste model geen rekening gehouden wordt met het effect van de mening van relevante anderen en geen rekening wordt gehouden met de mogelijkheid dat een bepaald gedrag meerdere gewolgen kan hebben.

De derde conclusie is dat de brulkbaarheid van dit model en de plaats van de beheersingsorientatie hierbinnen, het best bestudeerd kan worden aan de thand van nileuwe of instablele gedragingen. 
Different opinions exist among people about causation of diseases and about one"s possible contribution to recovery. Some people attribute health to good luck wile others stress one' a own contribution in respect to health maintenance or health restoration. Still others highly value medical expertise to keep them healthy. These opinions are defined as 10cus of control. In this research locus of control has been explored in connection with various health behaviours.

Locus of control has been conceptualised in detail in chapter two. Originally the concept energed within Rotter's social learning theory. In this study locus of control has been defined as an individual's general expectancy of who or what controls his/her behavioural outcomes and to what extend. A distinction has been made between locus of control and concepts like self-efficacy, outcome-expectations, locus of causality and powerlessness. Special attention has been paid to the latter. often powerlesiness is used as a synonym of external locus of control 1 .e. the opinion that behavioural outcomes are not self-controlled but controlled by external forces auch as physician, chance or luck. However the position taken, that behawioural outcomes are externally controlled, as such doean't inform on its unacceptability. The concept of powerlessness is used correctly if externel locus of control is perceived as unacceptable. Various studies suggeat that the concept locus of control may be subdivided according to different dimensions. A distinction can be made in respect to the different sources of control, such as the person him-/herself, powerfull othera, chance and luck; another distinction is that of the different relnforcement areas like health or political events and stil another is its valence, which may be positive or negative.

Based on these dimensions measurement criteria for locus of control have been formulated in chapter three. An important distinction has been made between aources of control, for internal and external locus of control have been demonatrated as independent factors. The above mentioned criteria have been used to discuss four Anglosaxon measurement-Instrumenta. It has been concluded that one-dimensionel instrumenta, like Rotter's scale, are leas usefull.

In chapter four the relation of $10 \mathrm{cus}$ of control and health behaviour has been discussed. Literature review reveals that research on this topic still isn't very coherent. Most reported atudies can be characterized as idiosyncratic. Hardly any attention has been pald to confounding factors auch as age and socio-economic atatus and to conditioning factors derived from social learning theory.

According to the theory locus of control is an important variable only if the individual velues behavioural outcomes and in case of a new or ambi- 
guous situation. The literature shows hardily any direct relations of lom cus of control and health behaviours. On the other hand there seess to be Indications, that intervention-progrem's based on internal locus of control tend to be more benificial to internally controlled people, while the opposite aeems true for externally controlled people.

Based on Rotter" aociall learning theory and Fishbein and Ajzen's conceptual framework research, questions have been formulated in chapter five. Chapter six describes the research design as part of a atudy to survey IIfe-style and subjective health assessment of the Dutch population in the age-groups from 20 to 65 years.

Deta have been collected at two different polnts in time namely 1981 and 1983. Standardized questionnaires have been used for data-collection. The total number of respondents was 882 . Data heve been excluded from respondents, who were under medical treatment for chronic disease and respondents who showed response tendency on the locus of control questionnaire. Actual dato-analysis has been carried out on 710 respondents.

Locus of control has been operationalized in chapter seven.

A apecific health locus of control acale has been used as measurement instrument. According to the literature this scale measures three distinct dimensions namely the internal, powerfull others- and chance-dimensions. Reliability and validity of the three subscales have been demonstrated aufficiently. As expected from the literature-review, locus of control appeared to relate to health condition. Respondents reporting bad health condition eppeared to score higher on powerfull others locus of control and lower on internal locus of control than repondents reporting good health condition. Furthermore locus of control appeared to be associated with some demographic variables such as age, socio-economic status and less strongly with sex. Females and youngsters scored higher on internal locus of control, while older people and respondents with lower socilom economic atatus acored higher on powerfull others- and chance locus of contral. Theae apecial effects have been corrected in further data-analysile.

The relation of locus of control and health behaviour has been analysed baged on Rotter's and Fishbelin and Ajzen's modela for explanation.

In chapter elght locus of control has been analysed within Rotter's theoretical framework. According to this model locus of control influences an Individual's behaviour in a direct way only as far as the individual volues its sanctions positively - like health in this case - or as far as it concerns a new or amblguous altuation. As a consequence based on this model no correlation may be expected between health behaviour and the diatrict dimensions of locus of control.

On the other hand interaction of the dimensions of locus of control may be expected to correlate with the health value.

Only if sanctions, which follow a certain behaviour, are valued positively by the individual, the individual will intend to perform the behaviour. Whether performance is actually carried out, still is another 
question. So intention to perform and actual performance have been diotinguished as units.

Data-analysis demonstrated no statisticel significant correlations of expected interactiona and intention to and reported health behaviour. On the other hand distinct dimensions of locus of control were in some inatances related to intention to and reported health behaviour. Powerfull others locus of control appeared to be positively correlated to an intention to consult a physician for complaints and negatively to auccessfull trials to stop amaking and drinking alcohol. Chance-externals appeared to smoke more often and appeared to be lesis successfull in stopping to smoke but they reported more physical exercise.

Locus of control also appeared to influence the relation of intention to perform and actual performance of behaviour. On powerfull others locus of control this relation appeared to be weak in respect to conaultation of a physician; besides trials to actually stop smoking appeared to fall more often. The same can be stated for chance locus of control in reapect to stopping to amoke.

Within the framework of Fishbein and Ajzen's model in chapter nine the queation hes been explored whether locus of control influences the way in which intention to perform behaviour emerges. According to Fiahbein and Afzen's model the intention to perform certain behaviour emerges from the attitude towards the behaviour and the aubjective norms about the behaviour. For internala it was hypothesized that attitude would correlate more atrongly to intention to perform then for non-internals.

While for powerfull others-externals it was hypothesized that subjective norms would correlate more strongly to intention to perform than for nonpowerfull others-externals.

Dato-analysis didn't demonstrate any statistically significant differences in respect to intention to smoke and to drink alcohol.

Nevertheless results strongly indicated that powerfull others externals and eapecially those who could also be labeled as nonmehance-externals tend to base their intention to amoke and drink alcohol not only upon their attitudes but also upon subjective norms about smoking and drinking.

Data-analysis has demonstrated, that interactions between the three locus of control-subscales often were related to (intentiona to) health behaviours. So in chapter ten the following conclusion has been formulated. The approach to analyse the relation of health behaviour and locus of control based on the trait model by which high and low scores are compared in respect to the three sub-gcales, probably is less usefull than the typology approach, by which, for instance, high internal locus of control and high powerfull others locus of control scores are compared with high internal locus of control and low powerfull othera locus of control scores.

The second conclusion drawn in this study states, that Fishbein and $\mathrm{AJ}_{\mathrm{J}}$ zen's model seems to be more adequate than Rotter's model for the purpose 
of exploring and analysing the relation of locus of control and health behaviour, the main reason for this being that the latter doesn't include the effect of subjective noms, nor the possibility that certain behaviour may have vartous outcones.

As a third and last conclusion it is defended thet the usefullness of the nodel of Flahbein and Ajzen and locus of control as part of it can be best demonstrated in respect to new and instabel behaviours. 
LITERATUURLIJST

Abramawitz, S.I. (1973). Internal-external control and soclal-political activism: test of the dimensionality of Rotter's internal-external acale. Journal of Consulting and Clinical Psychology, 40, 196-201.

Abramson, L.Y., M.E.P. Sellgman, J.D. Teasdale (1978). Learned helplesgness in humens: critique and reformulation. Journal of Abnormal Paychology, 87, 49-74.

Adriaanse, H., M.J. Drop, R. Halfens, H. Philipsen (1981). Leeft Nederland oke?: verslag van een onderzoek near de beleving, opvattungen en gedragingen inzake gezondheid, uitgevoerd door de RIjksuniversiteit Limburg augustus 1981. Masstricht, Rijksuniversiteit Limburg.

Adriaanse, H., M.J. Drop, K. de Mey, W. Verboom, L. de Witte (1984). Gezondheidsopvattingen en beroepsuitoefening. Maastricht, Rljksuniversiteit Limburg.

Ajzen, J., M. Fishbein (1980). Understanding attitudes and predicting social behavior. Englewood Cliffs, N.J., Prentice-Hall Inc.

Alleyn, J.J. (1983). Evaluatie van de geldigheid van een meetingtrument: health locus of control. Rotterdam, Studiecentrum Sociale Oncologie.

Andersen, L.M. (1979). The relationghip of locus of control health value, health behavior and health status in the elderly. Ann Arbor, Univeraity Microfilms International.

Andriessen, J.H.T.H. (1972). Interne of externe beheersing. Nederlands Tijdachrift voor de Paychologie, $27,173-178$.

Andriessen, J.H.T.H. (1974). Veiligheid, een kwestle van motivatie. Marburg, Gorich und Weliershauser.

Andriessen, J.H.T.H., J.P. van Cadsand (1983). Een analyse van de Nederlandse I.E.-schaal. Nederlands Tijdschrift voor de Psychologite, 38, $7-24$.

Apao, W.K., A.M. Damon (1982). Locus of control and the quantityfrequency index of alcohol use. Journal of Studies on Alcohol, 43, 233-239. 
Balch, P., A.W. Ross (1975). Predicting succes in weight reduction as a function of locus of control: a unidimensional and multidimensional epproech. Journal of Consulting and Clinical Psychology, 43, 119.

Bendura, A. (1977). Self-efficacy: toward a unifying theory of behavioral change. Psychologlcal Review, 84, 191-215.

Battle, E.H., A. Halliburton, K.A. Wallaton (1982). Self medication anong psychiatric patients and adherence after discharge. Journal of Psychosocial Nursing and Mental Health Services, 20, 21-28.

Baughman, M.K. (1978). The relationahip of locus of control and value belief a to health status and behavior among clerical workers. Dissertatie. Ann Arbor, University Microfilms International.

Beekers, M. (1982). Interpersoonlijke vaardigheidstherapieen voor kansarmen. Dissertatie. Lisse, Sweto \& Zeitlinger.

Belloc, N.B., L. Breslow (1972). Relationship of physical health atatus and health practices. Preventive Medicine, 1, 415-421.

Berkman, L.F., S.L. Syme (1979). Social networks, host resistance and mortality: a nine years follow up study of Alamede County residents. Anerican Journal of Epidemiology, 109, 186-204.

Best, J.A. (1975). Tailoring amoking withdrawal procedures to personality and mativational differences. Journal of Consulting and Clinical Psychology, $43,1-8$.

Best, J.A., R.A. Steffy (1975). Smoking modification procedures for internal and external locus of control clients. Cenadian Journal of Behavior Sciences, $7,155-165$.

Boogeard, P. ven den, A. Boomsme (1981). Diabetes, het ondergaan of er mee ongaan. Scrlptie. Ansterdam, Vrije Universiteit.

Boyle, E.S., B.E. Harrison (1981). Factor structure of the health locus of control scale. Journal of Clinical Psychology, 37, 819-824.

Boyle, E.S., K.A. Sielski (1981). Correlates of health locus of control in an older, disabled group. Journal of Paychology, 109, 87-91.

Buttler, M.C., R.G. Burr (1980). Utility of a multidimensional locus of control scale in predicting health and job-related autcomes in military environment. Paychological Reports, 47, 719-728. 
Butts, S.V., J. Chotlos (1973). A comparison of alcoholica and non-alcoholics on perceived locus of control. Quarterly Journal of Studies on Alcohol, 34, 1327-1332.

Cadsand, J.P. van (1977). Interne of externe beheersing. Doctoraal-scriptie Vakgroep Arbeids- en Organisatiepsychologie, Vrije Universitelt, Amsterdarn.

Cassee, E.H. (1973). Naar de dokter. Meppel, Boom.

Chambliss, C.A., E.J. Murray (1979a). Cognitive procedures for smoking reduction: symptom attribution versus efficacy attribution. Cognitive Therapy and Research, 3, 91-95.

Chambliss, C.A., E.J. Murray (1979b). Efficacy attribution, locus of control and weight loss. Cognitive Therapy and Research, 3, 349-353.

Charms, R. De (1968). Personal causation. New York, Academic Press.

Charms, R. De (1981). Personal causation and locus of control: two different traditions and two uncorrelated messures. In: H.M. Lefcourt (ed.). Research with the locus of control construct, vol. 1: Assesement methods, 337-358. New York, Academic Press.

Clarke, J.H., B.V. MacPheraon, D.R. Holmes (1982). Cigarette moking and external locus of control among young adolescents. Journal of Health and Social Behavior, 23, 253-259.

Clum, G.A., L. Scott, J. Burnside (1979). Information and locus of control as factors in the outcone of surgery. Psychologlcal Reporta, 45, 867873.

Coan, R.W., M.T. Falrchild, Z.P. Dobyns (1973a). Dimensions of experimental control. The journal of Social Paychology, 53-60.

Coan, R.W. (1973b). Personality variables asaociated with cigarette smoking. Journal of Personality and Social Psychology, 1, 86-104.

Collins, B.E. (1974). Four components of the Rotter internal-externel scale: belief in a difficult world, a just world, a predictable world, and a politically respansive world. Journal of Personality and Social Prychology, 29, 381-391.

Crandall, V.C., W. Kathorsky, V.J. Crandell (1965). Children's bellefs in their control of reinforcements in intellectual academic achievement behaviors. Child Development, 36, 91-109. 
Dabbs Jr., J.M., J.P. Kiracht (1971). "Internal control" and the teking of Influenza shota. Psychological Reports, 28, 959-962.

Danaher, B.G. (1977). Rapid moking and self-contral in the modiflcation of amoking behavior. Journal of Consulting and Clinical Psychology, 45, $1068-1075$.

DeVito, A.J., J. Bogdanowicz, M. Reznikoff (1982). Actual and intended health-related information seeking and health locus of control. Journal of Personality Assessment, 46, 63-69.

DiMatteo, M.R., D.D. DiNicola (1982). Achieving patient compliance: the psychology of the medical practitioner's role. New York, Pergamon Ceneral Pgychology Series.

Dirken, J.P. (1967). Het meten van stress in industriele organisaties. Groningen, Rijksumiveraiteit Groningen.

Dishmen, R.K., W. Ickeg, W.P. Morgen (1980). Self-motivation and adherence to habitual physical activity. Journal of Applied Social Psychology, 10. $115-132$.

Donovan, D.M., M.R. D"Leary (1975). Comparison of perceived and experienced control among alcoholics and non-alcoholics. Journal of Abnormal Psychology, 84, 726-728.

Donovan, D.M., M.R. O'Leary (1978). The drinking related locus of control scale. Journal of Studies in Alcohol, 94, 759-884.

Ducette, J., S. Molk, E. Soucar (1972). Atypical patterne in locus of cantrol and nonadaptive behavior. Journal of Personality, 40, 287-297.

Dunn, D.A. (1980). The relationehip of health locus of control and health value to medical aelf-care knowledge and attitudes of undergraduate and graduate health education majors in Oregon. Ann Arbor, Univeraity Microf Ime International.

Finch Jr., A.J., A. Spirito, Ph.C. Kendall, P.J. Mikulka (1981). Multidimensionality of the Vowlcki-Strickland locus of control scale for adulta. Journal of Personallty Assessment, 45, 151-154.

Fishbein, M., I. Ajzen (1975). Belief, attitude, intention and behavior: an introduction to theary and research. Reading, Mass., Addison-Wesley. 
Gal1, J.C. (1985). Instrumenteel onderzoek: een heranalyse van de Nederlandse I.E.-gchaal. Nederlanda Tijdschrift voor de Psychologie, 40, 158-189.

Gierszewskif, 5.A. (1983). The relationship of welght loss, locus of control, and social support. Nursing Research, 32, $43-47$.

Gattlieb, N.H., L.W. Green (1984). Life events, sociel network, life atyle and health: an analysis of the 1979 National survey of personal health practices and consequences. Health Education Quarterly, $11,91-105$.

Gregory, W.L. (1981). Expectancles for controllability, performance attributions and behavior. In: H.M. Lefcourt (ed.). Research with the locus of control construct, vol. 1: Assessment methods, 67-124. New York, Academic Pregs.

Gurin, P., G. Gurin, R.C. Leo, M. Beattie (1969). Internal-externall control in the motivational dynamics of negro youth. Journal of Social Issues, $25,29-53$.

Gurin, P., G. Gurin, B. Morriaon (1978). Personal and ideological aspecto of internal and external control. Social Psychology, 41, 275-296.

Haes, W.F.M. De (1985). Voorlichting en onderzoek. Nederlands Tijdachrift voor de Psychologie, 40, 63-70.

Halfene, R., M.J. Drop, H. Philipsen (1984). Leefwijzen en subjectieve gezondheid van een panel uit de Nederlandae bevolking. Masatricht, Rijksuniversiteit Limburg.

Hartke, R.J., J.T. Kune (1982). Multidimensionallty of health-related locus of control-scale items. Journal of Consulting and Clinical Paychology, 50, 594-595.

Heling, G.W.J. (1983). Locus of control voor gezandheid: een bijdrage aan de gedrags-wetenschappelijke ondersteuning van gezondheidsvoorlichting en -opvoeding. Nijmegen, Katholieke Universiteit Nijmegen.

Herzlich, C. (1973). Health and illness: a social psychological analysis. European Monographs in Social Psychology, 5. London, Academic Press.

Heunks, F.J. (1973). Allenatie en stengedrag. Tllburg, Instituut voor Sociaal-Wetenschappelijk Onderzoek aan de Katholleke Hogeachool THlburg.

Hill, D.J., R.M. Bale (1980). Development of the mental health locus of control and mental health locus of origin acales. Journal of Personality Assesment, 44, 148-156. 
D'Houtaud, A., M.G. Field (1984). The image of health varlations in perception by social cless in French population. Sociology of Health and I1lneas, $6,29-60$.

Janssen, 3., P. Voestermans (1978). De vergruisde universiteit. Meppel, Kripe Repro B.V.

Joe, V.C. (1971). Review of the internal-external control construct as a personality variable. Psychological Reports, 28, 619-640.

Joe, V.C., J.C. Jahn (1973). Factor structure of the Rotter I.E.scale. Journal of Clinicel Psychology, 29, 66-68.

Jong, H. De (1981). Verslag van de ontwikkeling van een schaal voor het meten van de "locus of control" voor huisartsen (Loch). In: N.U.H.I., somatiache fixatie, deel $V$.

Jonkers, R., M. Rutten, T. Romner, J. Alleyn, T. v.d. Harde (1981). Ongaan met borstkanker: een samenwerkingsprojekt van de Provinciale Krulisvereniging Zuid-Holland te Den Haag en het Studiecentrum Sociale Oncologie te Rotterdam van de Stichting Koningin Wilhelmina Fonds: le onderzoeksversleg april 1981 .

Jonkers, R., M. Rutten, T. Ronner, J.J. Alleyn, T. v.d. Horde (1982). Ongaan met borstkanker: een samenwerkingsprojekt van de Provinciale Kruiavereniging Zuid-Holland te Den Haag en het Studiecentrum Sociale Oncologie te Ratterdam van de Stichting Koningin Wilhelmina Fonds: eindrapport mei 1982 .

Joosten, J.. H. Philipsen (1978). De medische ernat van klachten en diagnosen: verslag van een beperkt onderzoek naar de mogelijkheid deskundigen te gebruiken als beoordelaars van de sterkte van de samenhang tusaen klachten en lichamelijke aendoeningen. Maastricht, Rijksuniversiteit Limburg.

Kaplen, G.D., M.A. Cowles (1978). Health locus of control and health value in the prediction of smoking reduction. Health Education Monographs, $6,129-137$.

Kincey, J. (1981). Internal-external control and weight loss in the obese: predictive and discriminant validity and some possible clinical implicationa. Journal of Clinical Psychology, 37, 100-103.

Kivett, V.R., J.A. Watson, J.C. Busch (1977). The relative importance of physical, psychological, and social variables to locus of control orientation in middle age. Journal of Gerontology, 32, 203-210. 
Klandermans, P.G., A.Ph. Visser (1983). Interne-externe beheersing en de theorie van het soclaal leren. Nederlands Tijdschrift voor de Psychologie, $38,1-6$.

Kok, G.J. (1978). Attitudes en gedrag. In: H. Wilke en G.J. Kok. Sociale paychologile in verandering, 35-47. Alphen an den Rijn, Samsam.

Kok, G.J., M.R. Buisman, P.O. Kampschuur, L. Kirst en P. van der Vange (1981). Attitudes, saciale normen en gedrag. Nederlands Tijdschrift voor de Paychologie, 36, 57-63.

Kok, G.J., H. de Vries (1985). Preventie van beginnend rookgedrag bij jongeren, toepassing van een sociaal-psychologisch beinvloedingamodel. In: J. von Grumbkow, D. van Kreveld, P. Stringer (eds.). Toegepaste sociale paychologie, 1, 56-69. Lisse, Swets \& Zeitlinger.

Koppelaar, L., G.P.J. Vlaander (1983). Externe beheersing en het effect van therapie en training. Nederlands Tijdgchrift voor de Poychologie, $38,25-33$.

Krantz, D.S., A. Baum, M. Widemen (1980). Assessment of preferences for self-treatment and information in health care. Journal of Personality and Social Psychology, 39, 977-990.

Kristiansen, C.M., Chr.M. Harding (in press 1985). The measurement of preventive health behavior. Exeter, England, Univeraity of Exeter.

Langlie, J.K. (1979). Interrelationahips among preventive health behavior: a test of competing hypotheses. Public Health Reports, 94, 216-225.

Lao, R.C. (1970). Internal-external control and competent and innovative behavior among negro college atudenta. Journal of Peraonality and 50cial Paychology, 14, 263-270.

Larde, J., J.R. Cloption (1983). Ceneralized locus of control and health locus of control of surglcal patients. Paychological Reporta, $52,599-$ 602 .

Leenders, F.H.R. (1983). Een theoretische exploratie van "locus of control" en "geneigdheid tot informatiezoeken" als opvoeder-variabelen in de opwoeder-kind interaktie. Tijdschrift voor Orthopedagogiek, 22, 822.

Lefcourt, H.M. (1976). Locus of control: current trends in theory and research. Hilladale, N.J., Erlbaim. 
Lefcourt, H.H. (1981a). The construction and developinent of the multidimenaional-multiattributional causality scales. In: H.M. Lefcourt (ed.). Reaearch with the locus of control construct, vol. I: Assessment methoda, 245-277. New York, Academic Press.

Lefcourt, H.M. (198lb). Overview. In: H.M. Lefcourt (ed.). Research with the locus of control construct", vol. 1: Assessment methods, 1-11. New York, Academic Pregs.

Levenson, H. (1973). Multidimensional locus of control in psychiatric patients. Journal of Consulting and Clinical Psychology, 41, 397-404.

Levenson, H. (1974). Activiam and powerful others: distinctions within the concept of internal-external control. Journal of Personality Assessment, $38,377-383$.

Levenson, H. (1981). Differentiating among internality, powerful others, and chance. In: H.M. Lefcourt (ed.). Research with the locus of control construct, vol. 1: Assessment methods, 15-63. New York, Academic Press.

Lewis, F.M., D.E. Morlsky, B.S. Flynn (1978). A test of the construct validity of health locus of control: effects on self-reparted compliance for hypertensive patients. Health Education Monographs, 6, 138-148.

Lewis, F.M., M.S. Beck (1983). Applied regression. Sage University Paper Series on Quantitative Applications in the Social Sciences, series no* 07-022. Beverly Hills and London, Sage Publications.

Linn, M.W., B.S. LInn, S.R. Stein (1982). Beliefs about causes of cancer in cancer patients. Journal of Sacial Sciences and Medicine, 16, 835839.

McCusker, J., G. Morrow (1979). The relationghip of health locus of control to preventive health behaviors and health beliefs. Patients Counaeling and Health Edueation, 1, 146-150.

Marah, A., J. Matheson (1983). Smoking attitudes and behaviour: an enquiry carried out on behalf of the Department of Health and Social Security. London, Her Majesty"s Stationery Office.

Mechanic, D., P.D. Cleary (1980). Factors associated with the maintenance of positive health behavior. Preventive Medicine, 9, 805-814.

Meyera, R., G.W. Donhan, K. Ludenia (1982). The psychometric properties of the health locus of control scale with medical and surgical patients. Journal of Clinical Psychology, 38, 783-787. 
Mirels, H. (1970). Dimenslons of internal versus external control. Journal of Consulting and Clinical Psychology, 34, 226-228.

Mischel, W., R. Zeise, A. Zelsa (1974). Internal-external control and perslistence: validation and implications of the Stanford preschool internal-external scale. Journal of Personality and Social Paychology, 29, 265-278.

Mlott, S.R., G.D. Mlott (1975). Dogmatism and locus of control in individuals who smoke, stopped smoking and never anoked. Journal of Community Psychology, 3, 53-57.

Mootz, M. (1981). De patient en zijn naasten: de invloed van houdingen in het persoonlijk netwerk van de patient op zijn medische consumptie. Dissertatie. "g-Gravenhage, J.H. Pasmans.

Mullins, L.C. (1982). Locus of desired control and petient role anong the institutionalized elderly. Journal of Social Psychology, 116, 269-276.

Neditch, M.P. (1975). Locus of control and drinking behavior in sample of men in army basic training. Journal of Conauling and Clinical Psychology, $43,96$.

Nie, N.H., C.H. Hull, J.G. Jenkins; K. Steinbrenner, D.H. Bent (1975). SPSS: Statiatical Package for the Social Sciences. 2nd ed. New York, MeGraw-Hill.

Orem, D.E. (1980). Nursing: concepts of practice. 2nd ed. New Yark, McGraw-Hill.

Ormel, H. (1980). Moeite met leven of een moeilijk leven: een vervolgonderzoek naar de invloed van psychosociale belasting op het welbevinden van driehonderd Nederlanders. Dissertatle. Groningen, Konstapel.

Parcel, G.S., M.P. Meyer (1978). Development of an instrument to measure children's health locus of control. Health Education Monographa, 6 , 149-159.

Paulhus, D., R. Christle (1981). Spheres of control: an interactionlat opproach to assessment of perceived control. In: H.M. Lefcourt (ed.). Research with the locus of control construct, vol. 1: Assessment methods, 161-188. New York, Academic Press.

Phares, E.J. (1976). Locus of control in personality. Mortistown, N.J., General Learning. 
Phillpaen, H. (1984). Commentaar op Mamasen en De Goede. Gezondheld en Samenlewing, $5,123-124$.

Pill, R., N.C.H. Stott (1981). Relationship between health lacus of control and belief in the relevance of life style to health. Patient Counseling and Health Education, 3, 95-99.

Prociuk, 1.J. (1977). Concerning the evidence for a general factor in the internal-external control scele: a reanalysis of Franklin's data. Journal of Consulting and Clinical Paychology, 45, 1199.

Reelick, N.F. (1982). Persoonlijkheidsfactoren en gezondheidsvoorlichting en -opvoeding. Rotterdam, G.G. en G.D. Ratterdam, Afd. G.V.D., rapport no. 318 .

Reid, D.W., E.E. Ware (1973). Multidimensionality of internal-external control implications for past and future research. Cenadian Journal of Behavior Sciences, 5, 264-271.

Riehl, J.P., S.C. Roy (1980). Conceptual models for nursing practice. 2nd ed. New York, Appleton-Century-Crofts.

Rodenburg, N. (1974). De macht van de deskundige: een onderzoek over machteloosheid en deskundigheid. Assen, Ven Gorcum.

Rogenblum, E.H., E.J. Stone, B.E. Skipper (1981). Maternal compliance in immunization of preschoolers as related to health locus of control, health value, and perceived vulnerability. Nursing Regearch, 30, 337342.

Rothbaum, F., J.R. Weigz, S.S. Snyder (1982). Changing the world and changing the self: two-process model of perceived control. Journal of Perconality and Soclal Paychology, 42, 5-37.

Rotter, J.B. (1954). Social learning and clinical psychology. Englewood Cliffa, N.J., Prentice-Hall Ine.

Rotter, J.B., M. Seeman, S. Liverant (1962). Internal veraus external control of reinforcementa: a major variable in behavior theory. Decisions, Values and Groups, 2, 473-516.

Rotter, J.B. (1966). Generalized expectations for internal versus external control of reinforcements. Pgychological Monographs, 80, (1, Whole no. 609). 
Rotter, J.B., J.E. Chance, E.J. Phares (1972). Applications of a soclal learning theory of personallty. New York, Holt, Rinehart and Winstion Inc.

Rotter, J.B. (1975a). Some problems and misconceptions related to the construct of internal versus external control of reinforcements. Journal of Consulting and Clinical Psychology, 43, 56-67.

Rotter, J.B. (1975b). Rotter'a social learning theory. In: J.B. Rotter and D.J. Hochreich. Pergonality, 93-114. Glenview, Scott, Foresman and Comp.

Rouwenhorst, W. (1981). Om onze gezondheid: de rol van gezondheidsvoorlichting en -opvoeding (GVO). Alphen aan den Rijn, Samsom.

Salltzner, E.B. (1978). Locus of control and the interaction to lose weight. Health Education Monographs, 6, 118-128.

Salltzner, E.B. (1982). The weight locus of control (WL.OC) scale: a specific measure for obesity research. Journal of Personality Assessment, $46,620-628$.

Schreiber, W.K. (1980). Locus of control and social desirability. Paychological Reports, 46, 1135-1136.

Seeman, M. (1959). On the meaning of alienation. American Sociological Review, 24, 783-791.

Seeman, M., J.W. Evans (1962). Alienation and learning in a hospltal setting. American Sociological Review, 27, 772-783.

Seeman, M., T.E. Seeman (1983). Health behavior and personal autonomy: a longitudinal study of the sense of control in illness. Journal of Hesith and Social Behavior, 24, 144-160.

Sellgman, M.E.P. (1975). Helplessness: on deptession, development, and death. San Francisco, Freeman.

Shipley, R.H. (1981). Maintenance of smoking cassation: effect of followup letters, moking motivation, muscle tension and health locus of control. Journal of Consulting and Clinical Psychology, 49, 982-984.*

Smith, B.C., H.M. Cargon (1981). The relationship of health locus of control to patients with end-stage renal disease. Patient Counseling and Health Education, second quarter, 63-66. 
Steele, J.L., W.H. MCBroon (1972). Conceptual and empirical diversions of health behavior. Journal of Health and Social Behavior, 13, 382-392.

Stralts, B.C., L. Sechrest (1963). Further support of aome findings about the cheracteristics of anokers and nonsmokers. Journal of Consulting Prychology, 27, 282.

Stricklend, B.R. (1978). Internal-external expectancies and health-related behaviors. Journal of Conisulting and Clinical Psychology, 46, 11921211 .

Swanborn, P.G. (1981). Methoden van sociaal-wetenschappelijk onderzoek: inleiding in ontwerpstrategieen. Meppel, Boom.

Tabachnick, B.G., L.5. Fidell (1983). Using multivariate statistics. New York, Harper and Row Publ.

Visaer, A.Ph. (1982). De samenhang tussen machteloosheid: kenmerken van de ziekenhuisomgeving en de beleving van patienten. Mens en Maatschappij, $57,290-304$.

Visaer, A.Ph. (1984). De beleving van het verblijf in het algemene ziekenhuis: tevredenheid, kennis en emotionele toestand van ziekenhuispatienten: meting, inhoud en determinanten. Dissertatie. Assen, Van Gorcum.

Walker, R.D., F. van Ryn, B. Frederick, D. Reynolds, M.R. Olleary (1980). Drinking-related locus of control as a predictor of atrition in an alcoholism treatment program. Psychological Reports, 47, 871-877.

Walkey, F.H. (1979). Internal control, powerful others and chance: a confirmation of Levenson's factor structure. Journal of Personality Asaesinent, $43,532-535$.

Wallaton, B.S., K.A. Wallston, G.D. Kaplan and S.A. Maldes (1976a). Development and validation of the health locus of control scale. Journal of Consulting and Clinical Psychology, 44, 580-585.

Wallston, B.S., K.A. Wallaton $(1978 b)$. Locus of control and health: a review of the literature. Health Education Monographs, 6, 107-117.

Wallaton, K*A*, S.A. Maides, B.5. Wallston (1976b). Health-related information seeking function of health-related locus of contral and health value. Journal of Research in Personality, 10, 215-222. 
Wallston, K.A., B.S. Wallston, R. DeVellig (1978a). Development of the multidimensional health locus of control (MHLC) scales. Health Education Monographs, 6, 160-169.

Wallstion, K.A., B.S. Wallston (1981). Health locus of control scalea. In: H.M. Lefcourt (ed.). Research with the locus of control construct, vol. 1: Assessment methods, 189-243. New York, Acadenic Press.

Wallaton, K.A., B.S. Wallston (1982). Who is responsible for your health?: the construct of health locus of control. In: G. Sanders \& J. Suls (eds.). Social Psychology of Health and Illness, 65-95. Hillsdale, N.J., Lawrence Erlbaum Ass.

Wiersma, D. (1979). Psychosociale "stress" en langdurige arbeldsongeschiktheid. Dissertatie. Groningen, Rijksuniveraiteit Groningen.

Williams, R.G.A. (1983). Concepts of health: an analyais of lay logic. 5ociology, 17, 183-205.

Worell, L., T.H. Tumilty (1981). The measurement of locus of control among alcoholics. In: H.M. Lefcourt (ed.). Research with the locus of control construct, vol. 1: Assessment methoda, 321-333. New York, Academic Press. 
BIJLAGE $\mathbb{1}$

Locur of Contral Scale (Rotter, 1966)

1.a. Many of the unhoppy things in people's lives are partly due to bad luck.

b. People's misfortunes result from the mistakes they make.

2.a. One of the major reasons why we have wars is because people don't take enough interest in politics.

b. There will always be wars, no matter haw hard people try to prevent them.

3.a. In the lang run people get the respect they deserve in this world.

b. Unfortunately, an individual's worth often passes unrecognized no matter how hard he tries.

4.a. The idea that teachers ore unfair to atudents is nonsense.

b. Most atudents don't realize the extent to which their grades are influenced by accidental happenings.

5.a. Without the right breaks one cannot be an effective leader.

b. Capable people who fail to become leaders have not taken advantage of their opportunities.

6.8. No matter how hard you try some people just don't like you.

b. People who can't get others to like them don't understand how to get along with others.

7.a. I have often found that what is going to happen will happen.

b. Trusting to fate has never turned out as well for me as making a decision to take a definite course of action.

8. a. In the case of the well prepared student there is rarely if ever guch a thing as un unfair test.

b. Many times exam questions tend to be so unrelated to course work that studying is really useless.

9.a. Becoming a success is a matter of hard work, luck has little or nothing to do with it.

b. Getting a good job depends mainly on being in the right place at the right time.

10. $\mathrm{a}$. The average citizen can have an influence in government decisions.

b. This world is run by the few people in power, and there is not much the little guy can do about it.

11.a. When I make plans, I am almoat certain that I can make them work.

b. It is not always wise to plan too far ahead because many things turn out to be a matter of good or bad fortune anyhow.

12.a. In my case getting what I want has little or nothing to do with luck.

b. Many times we might just as well decide what to do by flipping a coin. 
13.A. Who gets to be the boss often depends on who was lucky enough to be in the right place first.

b. Getting people to do the right thing depends upon ability, luck has little or nothing to do with it.

14.8. As far as world affairs are concerned, most of us are the victims of forces we can neither understand, nor control.

b. By taking an active part in political and social affairs the people can control world events.

15.a. Most people don't realize the extent to which their lives are controlled by accidental happenings.

b. There really is no such thing as "luck".

16.a. It is hard to know whether or not a person really 11 kes you.

b. How many friends you have depends upon how nice a person you are.

17.a. In the long run the bad things that happen to us are balanced by the good anes.

b. Most misfortunes are the result of lack of ability, ignorance, laziness, or all three.

18.a. With enough effort we can wipe out political corruption.

b. It is difficult for people to have much control over the things politicians do in office.

19.a. Sometimes I can't understand how teachers arrive at the grades they give.

b. There is a direct connection between how hard I study and the grades I get.

20. . Many times I feel that I have little influence over the thinga that happen to me.

b. It is impossible for me to believe that chance or luck plays an important role in my life.

21. a. People are lonely because they don't try to be friendly.

b. There"s not much use in trying too herd to please people, if they like you, they like you.

22. a. What happens to me 18 my own doing.

b. Sometimes I feel dat I don't have enough control over the direction my life is taking.

23.8. Most of the tilme I can't understand why politicians behave the way they do.

b. In the long run the people are responsible for bad government on a national as well as on a lacal level. 


\section{De elgemene beheeroor lentatie}

De In 1981 gebruikte algemene beheersingsorientetie-vragenlijst is afkonatig van Ormel (1980). Hij heeft de verkorte versie (14 items) van de I-E schael van Andriessen (1972) arangepast. Een drietal uitspraken die betrekking hadden op het politieke en maatschappelijke leven heeft hij verwijderd en vervangen door drie ultapraken die betrekking hebben op relationele en alledaagse gebeurtenissen.

Factor-analyse door Ormel (1980) leidde, met uitzondering wan twee items, tot een factor. De twee items met een lage lading zijn door ona verwijderd. Aangezien van de resterende 12 items er 10 in externe richting geformuleerd waren, zijn deze door ons in de meting van 1981 afwisselend intern en extern geformuleerd. Als antwoordschaal is hierbij gebruik gemaakt van een vijfpunts-Likert-schaal.

Factor-analyae op deze vragenlijat leidde tot de volgende vijf eigenwaarden: $2.8,2.0,1.1,0.9,0.9$. Op basis van het verloop van deze eigenwaarden zijn de eerate twee factoren, welke tesamen 40\% van de variantie verklaren, geroteerd met behulp van de varimax-methode. In tabel 1 zijn de factarladingen voor en na rotatie weergegeven.

Duidelijk is dat de intern en de extern geformuleerde items twee afzonderlijke factoren vormen. De interne betroumbarheid van de niddels sommatie verkregen schalen is .60 (interne schaal: 5 items) en .75 (externe schaal: 7 items). De samenhang tussen beide schalen bedraagt .02. 
Tabel 1 Factorladingen voor en ne rotatie van de beheersingsschael $(n=1278 ; 1981)$.

Uitspraken

Voor rotatie Na rotatie

fact.1 fact.2 fact.1 fact.2

1. Of mensen je aardig vinden of niet is lets was je zelf veel aan kunt doen

2. De meeste narigheden in je leven overkomen je zonder dat je er veel aan kunt doen

$\begin{array}{llll}-0.01 & 0.28 & 0.00 & 0.28\end{array}$

$\begin{array}{llll}0.48 & 0.02 \quad 0.48 & -0.01\end{array}$

3. Hogerop komen in het leven heb je vrijwel geheel of voor een groot deel zelf in handen

4. of je huwelijk goed uitpakt hangt voor een groot deel van jezelf of

$\begin{array}{llll}-0.08 & 0.52 & -0.05 & 0.53\end{array}$

$0.01 \quad 0.47 \quad 0.04 \quad \underline{0.46}$

5. Je kunt nog zo je best doen mear als het geluk je tegenzit mislukken veel dingen

$\begin{array}{llll}0.62 & 0.04 \quad 0.62 & 0.00\end{array}$

6. Of je een goede baan krijgt of niet, hangt er maar helemaal van af of je toevallig op het juiste moment op de juiste pleats bent

$\begin{array}{llll}0.52 & 0.12 \quad 0.53 & 0.09\end{array}$

7. Zonder de juiste kruiwagens kom je niet hoger op

$\begin{array}{llll}0.66 & 0.02 \quad 0.66 & -0.02\end{array}$

8. Gelukkig zijn is iets wat je voor een groot deel in eligen hand hebt

$\begin{array}{llll}-0.01 & 0.55 & 0.02 \quad 0.55\end{array}$

9. Veel beslissingen zouden we net zo goed kunnen nemen door een munt op te gooien

$\begin{array}{llll}0.43 & 0.07 & 0.43 & 0.05\end{array}$

10. Wat je bereiken wilt, wordt vrijwel helemaal doar jezelf bepaald

$\begin{array}{llll}-0.07 & 0.56 & -0.04 & 0.56\end{array}$

11. Ilk voel me vaker een slachtoffer van de omstandigheden

12. Hoe sterk lemand zich ook inspant, vaak wordt zijn waarde niet erkend.

$\begin{array}{lllll}0.53 & 0.15 & \underline{0.52} & -0.18 \\ 0.57 & 0.03 & \underline{0.57} & 0.00\end{array}$




\section{BI JLAGE 3}

Statistische gegevene van de variabelen, welke in hoofdatuk 6 bij de discriminant-anilyse gebruikt zijn ter vergelijking van de response en de non-response $(n=1278 ; 1981)$.

empiriache gemidd. standaard scheefh. betekenis apreiding deviatie

1. leeftijd $\quad 20-65 \quad 42.0 \quad 12.8 \quad .17$ jaren

2. sociaal econo$\begin{array}{llllll}\text { milache btatus } & 1-5 & 2.8 & 1.1 & .61 & \text { laag-hoog }\end{array}$

3. percentage gehuwden

$-\quad 78.9 \%$

4. aantal klachten (1) $0-21$

4.2

4.3

1.33

aantal

5. dokter sbezoeken/jaer $0-16$ $2 \cdot 2$ 3.6 2.35 anta1

6. medicijnen/ maand (2) $0-399$ $7.5 \quad 26.6$ 6.87 aantal

6a. medicljnen/ maand $(\log )(3) \quad 0-2.6 \quad .35 \quad .55 \quad 1.68$ aental

7 . waarde van gezondheld (4) $9-27$

19.6

3.2

-.73 weinig/veel

8. interne beheeraing (5) $7-25$ 18.5

2.9 $-.21 \quad$ laag-hoog

9. externe beheersing $6-30$

18.7

4. 1 .11 laeg-hoog

10. beinvloeden eigen gezondheld 1- 4

1.8

.7 .77 niet-hoge mate

11. Iicharmsbeweging/werk 
vervolg tabel bijlage 3

11a. Iichaamsbeweging/week

$\begin{array}{llllll}(\log )(3) & 0-1.52 & .23 & .33 & 1.22 & \begin{array}{l}\text { antal } \\ \text { uren } / \mathrm{dag}\end{array}\end{array}$

12. percentage rokers

49.8

13. alcohol/week

$0-84$

$7.4 \quad 10.1$

2.3 aentel glazen

(1) Aental klachten volgens de verkorte Vragenlijat over Ervaren Gezondheid (VOEG; 21 items; Cronbach's alphe $=.86$ )

(2) Als medicijn is gevraagd naar: aspirine, norit, laxeermiddelen, kalmeringsmiddelen en slasptabletten

(3) Vanwege de hoge scheefheid is de logeritme berekend en gebruikt voor het medicijngebruik en het aantal uren lichaamsbeweging

(4) Cronbach's alphe $=.79$

(5) zie bijlage 2 


\section{Opvattingen over medische wetengchep}

T1jdens het Interview in 1981 is de respondenten een lijst voorgelegd met uitapraken over de mediache wetenschap. Deze zijn in aangepaste vorm grotendeels ontleend aan Cassee (1973).

Op basis van factor-analyse bleek het mogelijk vrijwel alle uitspraken semen te voegen tat één schaal, welke als "scepsis t.o.v. de medische weterschap" te benoemen is (zie tabel 1). De eigenwarden van de eerste twee factoren waren 4.2 en 1.7 .

Om inhoudelijke reden is toch een verdere splitsing aangebracht in een factor scepsis t.o.v. de medische wetenschap en een machtige andere beheersingsorlentatie t.a.v. gezondheid. Middels sommatie zijn vervolgens twee schalen samengesteld. 
Tabel 1 Factor-analyse over uitspraken over artaen en medische wetenschep $(n=710 ; 1981)$

uitspraken

1. Voor veel kwalen klop je tevergeefs aen bij de medische wetenschap .49 .48 0.18

2. Als de modierne wetenschap zo anel vooruit blijft gaan, zullen nu nog ongeneeslijke ziekten in de toekomst worden genezen $-.11$

3. Veel ziekten hebben een achtergrond die door de medische wetenschap toch niet verholpen kan worden:

4. Het is altijd beter om naar de dokter te luisteren dan naar het advies van magnetiseura, strijkers, kruidendokters etc. -.31

5. De medische wetenschap belooft meer dan zilj kan doen

6. In een ziekenhuis weten ze precles wat goed voor je is

7. Als medicijnen niet helpen, kun je ze beter helemaal niet nemen

8. Ik heb een heel groot vertrouwen in de mediache wetenschap

9. Als je maar precies doet wat de dokter zegt, heb je de grootate kans on beter te worden 
vervolg tabel 1 bijlage 4

10. Artsen weten ook vaak niet wat ze moeten doen on lemand tie genezen

$.61 \quad .54 \quad-.28$

L1. Artsen schrijwen te gemakkelijk allerlel medicijnen voor

12. Doktoren belowen meer dan ze feitelijk kurnen doen

13. Artaen geven lang nilet altijd het juiste advies

14. Tegenwoordig kunnen artsen de meeste ziekten wel genezen

$\begin{array}{lll}-.41 & -.15 & .44\end{array}$

15. Artsen weten ook niet altijd wat goed voor je is

* De items, waarvan de factorladingen zijn onderstreept, zijn middels somscores samengevoegd tot twee schalen. 


\section{BIJLACE 5}

\section{Intentie tot ziektegedrag}

Om de intentie tot ziektegedrag te meten is aan de respondenten een Iijat met klachten (Mootz, 1981) voorgelegd, met de vraag wat men zou doen als men deze klacht had. Per klacht had men 6 antwoordmogelijkheden, namelljk:

-1 - geen aandacht aan beateden

-2- afwachten of het vanzelf overgast

-3- aspirine of ander geneesmiddel gebruiken

-4- de volgende dag naar het spreekuur van de dokter gaan

-5- de dokter zo snel mogelijk apbellen en on raad vragen

-6- lets anders, n1.:................ (S.V.P. OMSCHRIJVEN)

Door de categorieen "geen aandacht aan besteden" en "afwachten of het vanzelf overgaat" samen te voegen, evenals de categorleen "de volgende dag naar het spreekuur van de dokter gaan" en "de dokter zo snel mogelijk bellen en on raad vragen" zijn 4 antwoordcategorieen verkregen. In tabel 1 zijn hiervan de frequenties weergegeven. 
Tabel 1 De intentle tot ziektegedrag $(n=710 ; 1983$ in percentages)

afwachten geneesmid- dokter iets
delen ge- bezoeken anders
bruiken

1. U hebt sinde een week jeukende uitslag

2. U hebt een middag lang sterke pijn in de buik

3. U ontdekt op een keer bloed bij de ontlasting

4. U voelt zich ainds een week erg angstig

5. U hebt ineens lest van hartkloppingen

6. U hebt ainds een week gebrek an eetlust

7. II hebt op een ochtend 38 graden koorts

8. U voelt zich sinds een week ongewoon somber

9. U hebt vier dagen aaneen sterke dorst

10. U bent al drie dagen verkouden en u hebt keelpijn

11. U hebt een dag of vier lang hoofdpijn

12. U hebt op een achtend ekseem op de armen

13. U hebt sinds vier dagen glecht geslapen

14. U hebt op een dag ineens lagt van kortademigheid en benauwdheid

15. U moet ainda drie dagen vaker plassen dan $u$ norms 1 acht

16. U voelt zlch al een week of twee niet echt fit

17. U voelt een dag of twee pijn in de rug

18. U voelt zich sinds wijf dagen erg zenuwachtig
39

49

66

81

71

61

2

57

2

1

1

7

2

2

2

4

4

2

2

1

3

599

43

410


BIJLAGE 6

Interne consigtentie en intercorrelaties van de drie HLC-schalen.

Tabel 1 De interne consistentie var de drie HLC-schalen bij verechillende steekproeven en panels (1983).

IHLC PHLC CHLC

$\begin{array}{llll}\text { chronisch gehandicapten (128)1 } & .78 & .81 & .71 \\ \text { bevolking (ateekproef: 296)1 } & .75 & .80 & .71 \\ \text { niet-actieven (panel: 146)1 } & .78 & .76 & .72 \\ \text { niet-actieven (ateekproef: } 95 \text { )1 } & .78 & .75 & .75 \\ \text { wijkverpleging }(99) 2 & .77 & .75 & .70 \\ \text { leerkrachten }(97) 2 & .74 & .70 & .67\end{array}$

(1) panels ateekproeven uit het panelonderzoek (gecorrigeerd voor entwoordtendenties).

(2) steekproeven uit ander onderzoek (Adriaanse e.a., 1984). 
Iabe1 2 Intercorrelatles tussen de drie beheersingsorientatieschalen voor de verschillende groepen (1983).

IHLCFPHLC IHLC*CHLC PHLC*CHLC

$\begin{array}{llll}\text { chronisch gehandicapten }(128) 1 & -.02 & -.02 & .29 * * * \\ \text { bevolking (steekproef; } 296) 1 & .31 * * * & .18^{* * *} & .47^{* * *} \\ \text { niet-actleven (panel; } 146) 1 & .06 & .19 * * * & .34 * * * \\ \text { wijkverpleging }(99) 2 & -.12 & .09 & .35 * * * \\ \text { leerkrachten }(99) 2 & -.05 & -.19 * & .47^{* * *}\end{array}$

(1) panels en steekproeven uit panelonderzoek

(2) steekproeven uit ander onderzoek (Adriaanse e.a., 1984)

* $\mathrm{p}^{*} .05$

** $\mathrm{p}^{\circ} .01$

$* * * p^{*} .001$ 


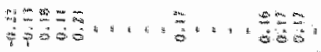

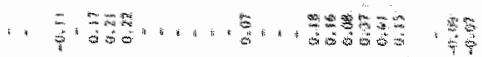

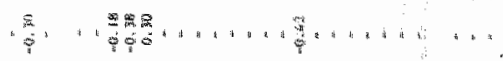

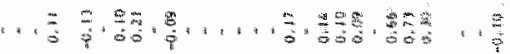

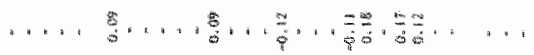$$
\text { ;, , , , s }
$$

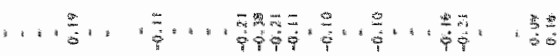

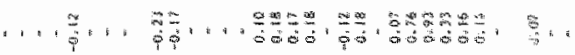

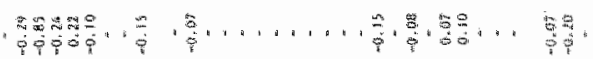

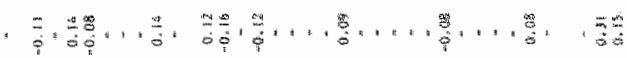

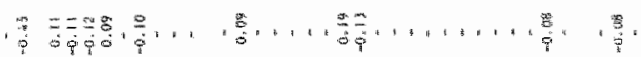

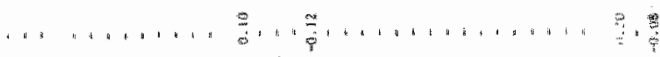$$
\text { " }
$$

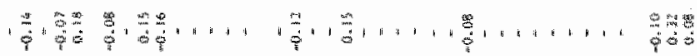

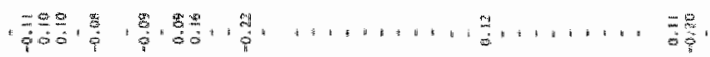

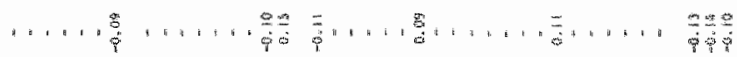

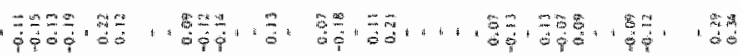$$
\text { , 等 }
$$

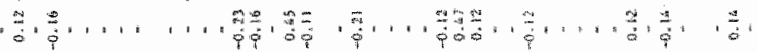

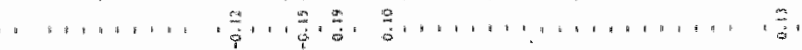

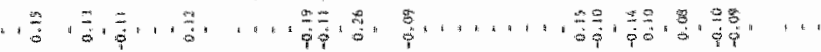

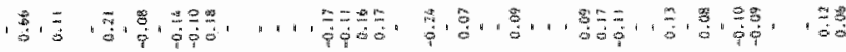

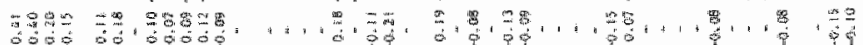

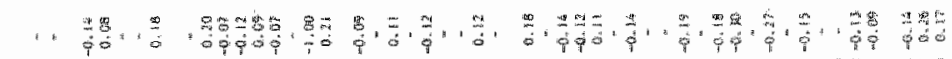

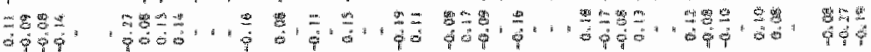

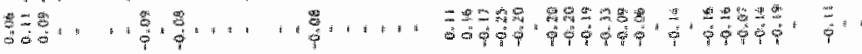

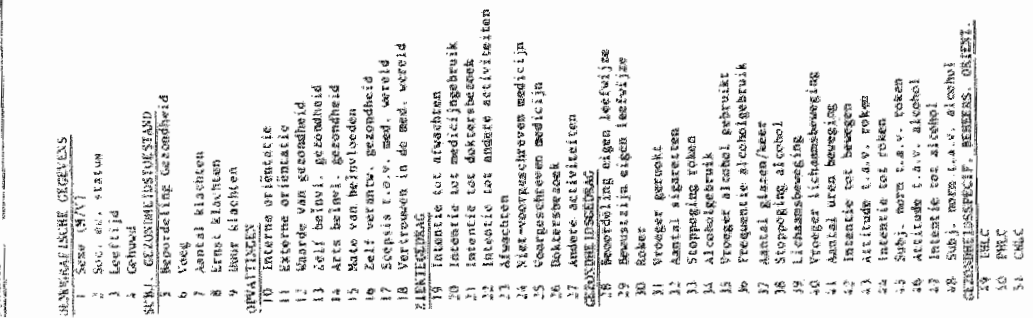




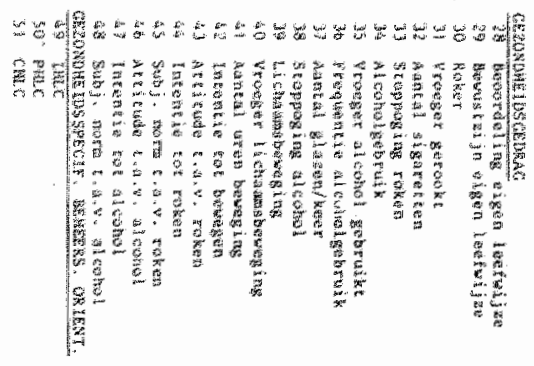

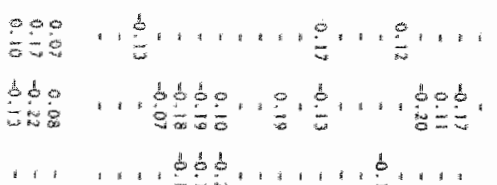

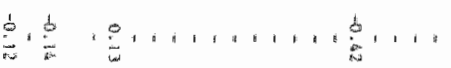

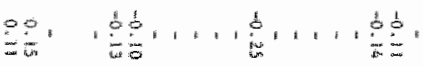

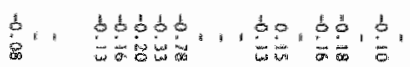

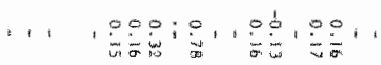

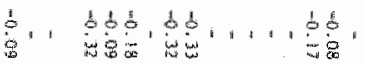

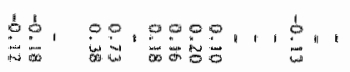

,

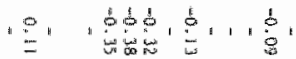

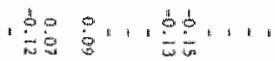

*1 1 * +

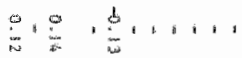

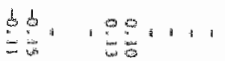

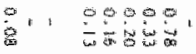

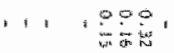

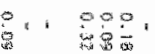

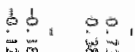

$\sum_{i=1}^{\infty}$

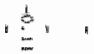


DANKWOORD

Op deze plasts wil ik eenieder bedanken, die op directe of indirecte wijze heeft bijgedragen aan de tot atandkoming van dit proefachrift.

Mijn beide pronotores - Prof. Dr. A. Appels en Prof. Dr. H. Philipsen ben ik zeer erkentelijk voor de prettige en deskundige begeleiding. Prof. Dr. A. Appels dank ik voor de nauwgezette wijze warop hij de verachillende concepten gelezen heeft. Zijn betrokkenheid en constructieve benedering zijn steeds stimulerend geweest. Prof. Dr. H. Philipsen dank ik voor het feit dat hij steeds klaar stond op die momenten warop zijn hulp en adviezen gewenat waren. Voorts is zijn vertrouwen in het wels.lagen van deze onderneming een belangrijke steun geweest.

De beide referenten - Dr. A.Ph. Visser en Prof. Dr. G.J. Kok - dank ik voor de snelle en kundige wijze warop ze het manuscript van commentaar hebben voorzien. Dr. A.Ph. Visser dank ik voorts voor de nauwgezette wijze waarop hij het manuscript gelezen heeft; zijn bemerkingen zijn het proefachrift zeker ten goede gekomen. Prof. Dr. G.J. Kok dank ik tevens voor zijn adviezen met betrekking tot het model van Fishbein en Ajzen.

Verder dank ik de oorspronkelijke leden van het onderzoeksteam, Drs. H. Adriaange, Prof. Dr. M.J. Drop en Prof. Dr. H. Philipaen. Zlj boden mij de gelegenheid te participeren in het panelonderzoek "Leefwijze en subjectieve gezondheid" en zodoende ook de mogelijkheid de gegevens te verzamelen die voor dit proefschrift zijn gebruikt. Hen wil ik danken voor de prettige en leerzame samenwerking.

Dank gaat ook wit naer de wetenschappelijke begeleidingscommisaie van de Stichting Nederland oke, die het panelonderzoek "Leefwijze en subjectieve gezondheid" begeleidde.

Henny Prick en Julle Rasier-Wolfa hebben de tekgtverwerking van de diverse concepten verzorgd. Hen ben $1 \mathrm{k}$ zeer erkentelijk voor de deakundige en enthousiaste wijze warop dit steeds gebeurd lB. Zonder hun inzet zou dit proefachrift niet op tijd zijn klaar gekomen.

Verder dank ik Nanno de Vries voor zljn adviezen inzake variantie-analyae, Yvonne Halfens voor het corrigeren van de eindtekst, George Evers voor het schrijven van de Engelse samenvatting, Marian Tilly voor het samenatellen van de literatuurlijat, en Marie-Jeanne van Gils voor het ontwerpen van de omsilag.

Mijn collega's bij de Capaciteitsgroep Verplegingswetenschap ben ik zeer erkentelijk voor het felt dat $z i j \mathrm{mij}$ de ruimte geboden hebben dit proefschrift te schrijven. Mijn ex-collega" bij de Capaciteitagroep Gezondheldavoorlichting en -Opvoeding dank ik voor het feit dat zij mij de gelegenheid gaven de kennis en kunde op te doen, die nodig waren om dit proefachrift te kunnen schrijven.

Dok mijn ouders will ik op deze plaats danken. Zij boden mij de gelegenheid de verelste vooropleiding te volgen.

En tenslotte dank ik Marthe voor haer hulp en steun op diverge fronten. 
De auteur van dit proefschrift werd op 20 juli 1952 geboren te Tegelen. $\mathrm{Na}$ het behalen van zijn H.B.S.-B diploma aan thet St. Thomascollege te Venlo in 1972, ging hij psychologie atuderen aan de Katholieke Universiteit te Nigmegen. In januari 1980 behaalde hij het doctoraalexamen met als hoofdvak psychologle van arbeid en organisatie en de bijwakken economie voor de poychologie, en leer der interne arganisatie.

Van auguatus 1976 tot juni 1977 was hij als student-assistent verbonden aan de vakgroep Paychologie van arbeld en organisatie.

Vanef jull 1980 is hij werkzaam bij de Rijksunivergiteit Limburg. Als wetenachappelijk ambtenaar werkte hij van juli 1980 tot oktober 1990 bij de Capaciteitagroep Medische Psychologie, en van oktober 1980 tot Pebruari 1984 bij de Capaciteitagroep Gezondheidsvoorlichting en -0pwoeding. Bij de laatste werkte hij an het panelonderzoek "Leefwijzen en subjectieve gezondheid".

Vanaf februari 1984 is hij verbonden an de Capaciteitsgroep Verplegingswetenschap, in de functie van wetenschappelijk medewerkex. 